\section{Proceedings of the} North Aleutian Basin Information Status and Research Planning Meeting

Anchorage, Alaska

November 28 - December 1, 2006

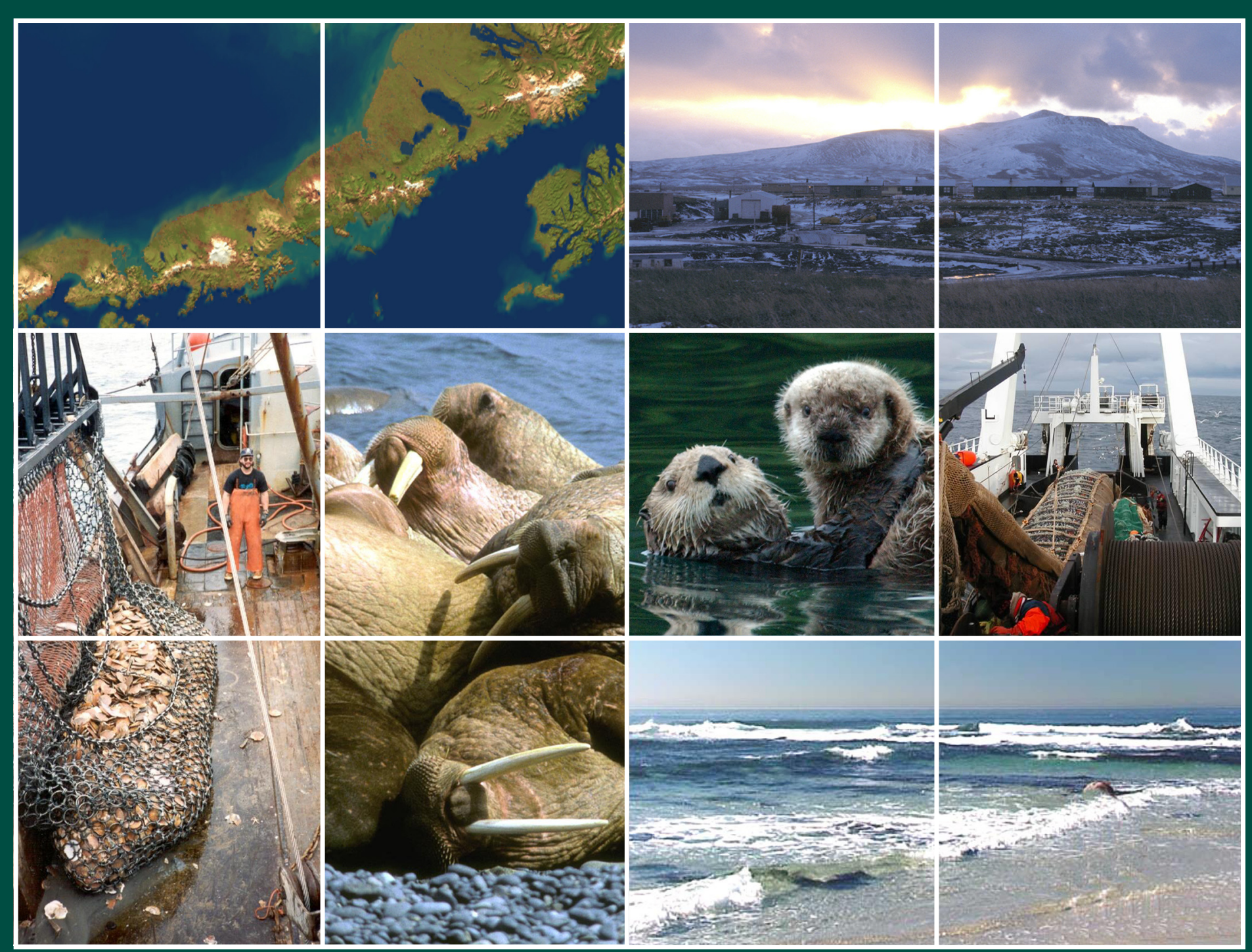

Minerals Management Service - Alaska Region

Argonne National Laboratory

MMS 
About Argonne National Laboratory

Argonne is a U.S. Department of Energy laboratory managed by UChicago Argonne, LLC

under contract DE-AC02-06CH11357. The Laboratory's main facility is outside Chicago,

South Cass Avenue, Argonne, Illinois 60439. For information about Argonne,

\section{Disclaimer}

This report was prepared as an account of work sponsored by an agency of the United States Government. Neither the United States Government nor any agency thereof, nor UChicago Argonne, LLC, nor any of their employees or officers, makes any warranty, express product, or procoess disclosed, or reperesents that its use would not infringe privately owned rights. Referennce herein to any specific commercial product, process, or service by trade name, trademark, manufacturer, or otherwise, does not necessarily constitute or imp document authors expressed herein do not necessarily state or erfect those of the United States Government or any agency thereof document authors expressed herein do not necessarlil stat
Argonne National Laboratory, or UChicago Argonne, LLC. 
PROCEEDINGS OF THE NORTH ALEUTIAN BASIN

INFORMATION STATUS AND RESEARCH PLANNING MEETING

NOVEMBER 28 - DECEMBER 1, 2006

ANCHORAGE, ALASKA

prepared by

Environmental Science Division

Argonne National Laboratory

Argonne, Illinois

for

U.S. Department of Interior

Minerals Management Service

Alaska Outer Continental Shelf Region

Anchorage, Alaska

OCS Study MMS 2007-031

June 2007 



\section{CONTENTS}

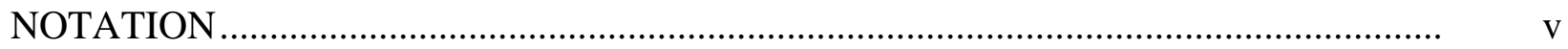

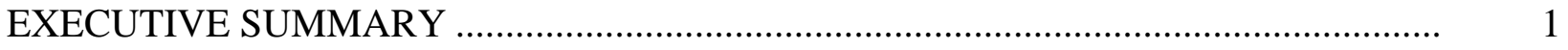

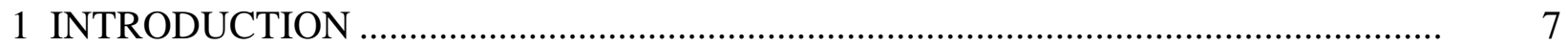

2 MEETING DESCRIPTION AND APPROACH...................................................... 11

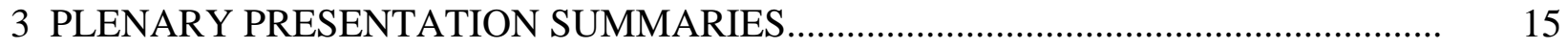

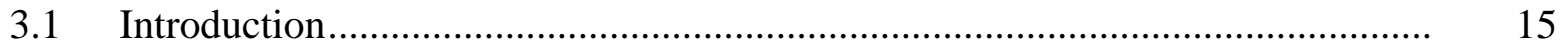

3.2 Outer Continental Shelf Oil and Gas Leasing Program, 2007-2012................. 15

3.3 Identifying Information Needs and Research Priorities for the North Aleutian Basin of Alaska .................................................................... $\quad 18$

3.4 Developing a Literature Database for the North Aleutian Basin of Alaska ....... 19

3.5 Potential Financial and Employment Impact from the Development of Oil and Gas in the North Aleutian Basin ....................................................... $\quad 24$

3.6 Circulation, Water Mass Distribution, and Transports in the North Aleutian Basin—Model Results ........................................................ 26

3.7 Marine Fish Abundance and Distribution in the MMS North Aleutian Basin Program Area ..................................................................................... 27

3.8 Federal Fisheries in the North Aleutian Basin................................................. 29

3.9 Potential Impacts of North Aleutian Basin Oil and Gas Development on Commercial Fisheries: What Do We Know? What Research Is Needed? ......... $\quad 30$

3.10 Community Socioeconomics: North Aleutian Basin ....................................... 33

3.11 Subsistence Research in the North Aleutian Basin........................................... 36

3.12 Bristol Bay-North Aleutian Basin Seabirds and Shorebirds ............................ 38

3.13 Bristol Bay-Alaska Peninsula: Avian Crossroads and Destination.................... 39

3.14 Important Pinniped Populations: North Aleutian Basin ................................. 41

3.15 Right Whales and Other Cetaceans in the North Aleutian Basin ...................... 44

3.16 The North Aleutian Basin: Northern Sea Otters and Pacific Walrus.................. $\quad 49$

4 WORKING GROUP PROCESS AND FINDINGS .................................................

4.1 Oceanography, Ecosystems, and Fate and Effects....................................... 53

4.2 Socioeconomics and Subsistence............................................................ 57

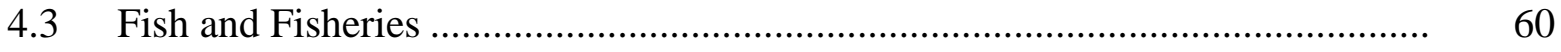




\section{CONTENTS (Cont.)}

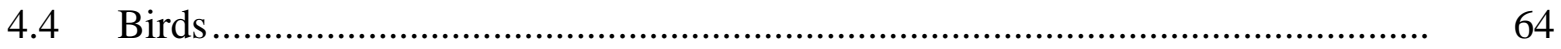

4.5 Marine Mammals .................................................................................... 66

5 CONCLUSIONS AND RECOMMENDATIONS …...................................................

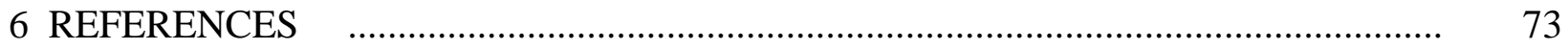

\section{APPENDICES}

A Registrants and Work Group Members of the North Aleutian Basin Information Status and Research Planning Meeting ........................................................ 75

B Speaker Biographies and Presentations Given at the North Aleutian Basin Information Status and Research Planning Meeting ..................................................... 85

C Study Profiles Developed at the North Aleutian Basin Information Status and Research Planning Meeting.................................................................................... 173

C.1 Oceanography, Ecosystems, and Fate and Effects Study Profiles....................... 175

C.2 Socioeconomics and Subsistence Study Profiles ................................................... 195

C.3 Fish and Fisheries Study Profiles...................................................................... 201

C.4 Birds Study Profiles ........................................................................................ 225

C.5 Marine Mammals Study Profiles ...................................................................... 239

\section{TABLES}

1 Information Status and Research Planning Meeting Agenda ......................................... 12

2 Affiliations of Registrants for the North Aleutian Basin Information Status and Research Planning Meeting.

3 Affected Resources Identified for Further Evaluation in the Oceanography, Ecosystems, and Fate and Effects Working Group

$4 \quad$ Fish and Fisheries Working Group Study Profiles ......................................................... 63

$5 \quad$ Study Profiles Developed by the Marine Mammals Working Group........................... $\quad 70$

A-1 Registrants of the North Aleutian Basin Information Status and

Research Planning Meeting

A-2 Participants in North Aleutian Basin Working Groups

\section{FIGURES}

1 North Aleutian Basin Planning Area and Historic Sale 92 Area 


\section{NOTATION}

The following is a list of the acronyms, initialisms, and abbreviations used in this document.

$\begin{array}{ll}\text { ADFG } & \text { Alaska Department of Fish and Game } \\ \text { AMNWR } & \text { Alaska Maritime National Wildlife Refuge } \\ \text { Argonne } & \text { Argonne National Laboratory } \\ \text { EIS } & \text { environmental impact statement } \\ \text { ESA } & \text { Endangered Species Act } \\ \text { FMP } & \text { Fishery Management Plan } \\ \text { FY } & \text { fiscal year } \\ \text { GIS } & \text { geographic information system } \\ \text { LNG } & \text { liquefied natural gas } \\ \text { MMPA } & \text { Marine Mammal Protection Act } \\ \text { MMS } & \text { Minerals Management Service } \\ \text { NEPA } & \text { National Environmental Policy Act } \\ \text { NMFS } & \text { National Marine Fisheries Service } \\ \text { NMML } & \text { National Marine Mammal Laboratory } \\ \text { NOAA } & \text { National Oceanographic and Atmospheric Administration } \\ \text { NPPSD } & \text { North Pacific Pelagic Seabird Database } \\ \text { NPRB } & \text { North Pacific Research Board } \\ \text { OCS } & \text { Outer Continental Shelf } \\ \text { USFWS } & \text { U.S. Fish and Wildlife Service }\end{array}$




\title{
PROCEEDINGS OF THE NORTH ALEUTIAN BASIN INFORMATION STATUS AND RESEARCH PLANNING MEETING
}

\author{
prepared by
}

\author{
Kirk E. LaGory, John R. Krummel, John W. Hayse, \\ Ihor Hlohowskyj, Elisabeth A. Stull, and Larry Gorenflo \\ Environmental Science Division \\ Argonne National Laboratory \\ Argonne, Illinois
}

\section{EXECUTIVE SUMMARY}

The North Aleutian Basin Planning Area of the Minerals Management Service (MMS) is a large geographic area with significant ecological and natural resources. The Basin includes most of the southeastern part of the Bering Sea continental shelf including all of Bristol Bay. The area supports important habitat for a wide variety of species and globally significant habitat for birds and marine mammals including federally listed species. Villages and communities of the Alaska Peninsula and other areas bordering or near the Basin rely on its natural resources (especially commercial and subsistence fishing) for much of their sustenance and livelihood. The offshore area of the North Aleutian Basin is considered to have important hydrocarbon reserves, especially natural gas.

In 2006, the MMS released a draft proposed program, Outer Continental Shelf Oil and Gas Leasing Program, 2007-2012 and an accompanying draft programmatic environmental impact statement (EIS). The draft proposed program identified two lease sales proposed in the North Aleutian Basin in 2010 and 2012, subject to restrictions. The area proposed for leasing in the Basin was restricted to the Sale 92 Area in the southwestern portion. Additional EISs will be needed to evaluate the potential effects of specific lease actions, exploration activities, and development and production plans in the Basin. A full range of updated multidisciplinary scientific information will be needed to address oceanography, fate and effects of oil spills, marine ecosystems, fish, fisheries, birds, marine mammals, socioeconomics, and subsistence in the Basin.

Scientific staff at Argonne National Laboratory (Argonne) were contracted to assist the MMS Alaska Outer Continental Shelf (OCS) Region in identifying and prioritizing information needs related to the North Aleutian Basin and potential future oil and gas leasing and development activities. The overall approach focused on three related but separate tasks: (1) identification and gathering of relevant literature; (2) synthesis and summary of the literature; and (3) identification and prioritization of information needs. To assist in gathering this information, MMS convened the North Aleutian Basin Information Status and Research Planning Meeting, held in Anchorage, Alaska, from November 28 through December 1, 2006; this report presents a summary of that meeting. The meeting was the primary method used to gather input from stakeholders and identify information needs and priorities for future inventory, 
monitoring, and research related to potential leasing and oil and gas developments in the North Aleutian Basin. The purposes of the meeting were to:

- Involve a broad range of stakeholders and scientists in science planning for the North Aleutian Basin;

- Plan early for pertinent studies and research in key disciplines and topics to be sponsored by the MMS Environmental Studies Program;

- Identify recommended studies and preliminary priorities based on involvement of meeting attendees;

- Obtain preliminary assessment from MMS of the feasibility, appropriateness, and scientific value of inventory, monitoring, and research activities; and

- Identify preliminary priorities of feasible studies based on MMS Alaska OCS Region mission relevance, timing needs, scientific quality, cost, and other criteria such as implementation considerations.

Prior to the meeting, Argonne staff gathered the literature relevant to the Basin that had been authored over the last 10 years (1996 through 2006) and developed a database of that literature for use at the meeting. A synthesis report of this literature will be issued separately from these proceedings.

A total of 190 individuals were invited to participate in the meeting. Invited individuals represented a mix of research scientists, public agency managers, and stakeholders from local government, commercial fishing, subsistence organizations, tribal organizations, and environmental organizations. Of the 113 meeting registrants, MMS invited and paid for the travel expenses of 16 local stakeholders from the Aleutians East Borough, Aleutian Pribilof Islands Association, Bristol Bay Borough, Friends of Bristol Bay, and Lake and Peninsula Borough.

The first day of the meeting consisted of a plenary session in which background information was provided to participants including the objectives of the meeting, an overview of MMS's 2007-2012 five-year program plan, the results of Argonne’s literature review, and topical presentations by subject matter experts (i.e., individuals with research experience in the North Aleutian Basin) on physical oceanography, fish and shellfish populations, federal fisheries, commercial fishery economics, community socioeconomics, subsistence research, seabirds and shorebirds, waterfowl, seals and sea lions, cetaceans, and sea otters and walruses. The intent of this plenary session was to provide sufficient background information for meeting participants on the full array of subject areas to enable them to identify and prioritize information needs relevant to environmental assessments of oil and gas development in the Basin.

On the second and third days of the meeting, participants broke into five working groups, each facilitated by an Argonne staff member. The five working groups included (1) oceanography, ecosystems, and fate and effects of oil spills; (2) socioeconomics and subsistence; (3) fish and fisheries; (4) birds; and (5) marine mammals. The objectives of each working group were to (1) review the status of existing information; (2) identify information needs to support future environmental assessment activities in the Basin; (3) prioritize those 
information needs; and (4) develop proposed study profiles to fill high priority information needs. areas:

Thirty-five study profiles were developed by working groups in the following topical

- Oceanography, ecosystems, and fate and effects of oil spills

- Implementation of a meteorological buoy

- Mesoscale meteorological modeling

- Physical oceanography field program

- Modeling of circulation

- Characterization of sediments

- Characterization of benthic communities

- Intertidal community characterization

- Identification and characterization of eelgrass communities

- Determination of sea ice edge productivity

- Socioeconomics and subsistence

- North Aleutian Basin socioeconomics

- North Aleutian Basin subsistence

- Fish and fisheries

- $\quad$ North Aleutian Basin nearshore forage fish seasonal distribution and spawning survey

- Seasonal distribution and condition of juvenile Pacific salmon and young of the year pollock within the North Aleutian Basin

- $\quad$ North Aleutian Basin ichthyoplankton and zooplankton monitoring

- Compilation of historical information on seismic surveys and fisheries in the North Aleutian Basin

- Evaluation of potential for space-use conflicts between fishery activities and oil and gas development activities within the Sale 92 Area

- $\quad$ Nearshore distribution of juvenile flatfishes in the eastern Bering Sea

- North Aleutian Basin fishing communities

- $\quad$ Bering Sea fish catalog

- $\quad$ Bering Sea seasonal fish migration

- Birds

- Spatial and temporal distribution of Steller's eiders (Polysticta stelleri) and other waterbirds

- $\quad$ Spatial and temporal distributions of birds at sea 
- Seabird colony census and diet

- Aerial remote sensing of distribution and abundance of eelgrass

- Estuarine systems - Izembek and Port Moller Lagoons

- Spatial and temporal patterns of bird movements

- Marine mammals

- Distribution, abundance, and habitat use of North Pacific right whales (Eubalaena japonica)

- Seasonal acoustic monitoring of right whales and other endangered cetaceans

- Abundance, distribution and seasonal movements of humpback whale (Megaptera novaeangliae), fin whale (Balaenoptera physalus), and other cetaceans

- Health assessment of stranded marine mammals

- Steller sea lion (Eumetopias jubatus) seasonal distribution and diet

- Steller sea lion seasonal habitat use

- Harbor seal (Phoca vitulina) and spotted seal (Phoca largha) seasonal distribution

- Seasonal distribution and abundance of Pacific walrus (Odobenus rosmarus divergens)

- Seasonal distribution and abundance of northern sea otter (Enhydra lutris kenyoni)

Plenary speakers and meeting participants emphasized the critical importance of resources in the North Aleutian Basin including human subsistence resources, commercial fisheries, and internationally important bird and marine mammal populations and habitats. In general, meeting participants believed that current information is insufficient to address oil and gas leasing issues. The study profiles that were developed at the meeting represent the highest priority studies identified by the working groups.

Some of these information needs can be addressed by systematically evaluating existing data collected by various agencies with an eye towards characterizing distribution and status of resources and patterns of change that could be responses to environmental perturbations in the last few decades. These types of analyses could be particularly important for assessing the effects of leasing, exploration, development, and production activities related to oil and gas development. Study profiles were developed in these areas, and, if funded, could represent an important first step for the program.

Some topics are critically important to address with further study because (1) there is little Basin-specific information on them, (2) the resources they address are considered of vital importance, and (3) additional information is needed as early as possible in the lease-explorationdevelopment-production timeline. On the basis of information gathered at the meeting, Argonne staff identified two topics that fit these criteria: studies of the endangered North Pacific right whale and studies of subsistence patterns. The North Pacific right whale is an endangered species with critical habitat in the Basin, specifically in the Sale 92 Area. Data are needed early because the species is potentially affected by seismic surveys that could occur within the next few years. 
Subsistence resources are vitally important to residents of the areas and could be affected by all aspects of oil and gas development including leasing and exploration. These study profiles are of greatest importance in the earliest phases of the North Aleutian Basin leasing program.

Assessments of the effects of oil and gas development activities in the North Aleutian Basin could greatly benefit from development of a high-resolution model of the Basin that characterizes important physical processes. Such a model would be useful for predicting the fate and effects of oil spills or other contaminant releases and could be linked to information collected about other resources in the Basin to better understand the underlying basis of distributions, seasonal patterns of use, population trends, or changes in resource status. Although a fully developed high-resolution model would be useful now, it will be most critical several years from now for use in the assessments of development and production plans.

Other study profiles that were developed at the meeting will be useful for developing a monitoring program of the effects of oil and gas development in the North Aleutian Basin. To be most effective, these studies should start sometime prior to the initiation of oil and gas activities in order to establish baseline data.

Studies and the environmental assessment program they support will be greatly strengthened by strong communication among principal investigators and MMS staff and integration of studies to the extent possible. Studies should focus on hypothesis testing and employ robust statistical design using appropriate sample sizes and data quality objectives identified before the studies are implemented. Standardization of common data needed by several programs, avoidance of duplication of effort, and development of a Web-based data system using standard metadata procedures would improve the usability of results and make them available to a wider group of users. 


\section{INTRODUCTION}

The North Aleutian Basin Planning Area of the Minerals Management Service (MMS) is a large geographic area (more than $130,000 \mathrm{~km}^{2}$ [50,000 mi $\left.{ }^{2}\right]$ ) with significant ecological and natural resources. The Basin includes most of the southeastern part of the Bering Sea continental shelf including all of Bristol Bay (Figure 1). The area supports important habitat for a wide variety of species and globally significant habitat for birds and marine mammals including a number of federally listed species. Villages and communities of the Alaska Peninsula and other areas bordering or near the North Aleutian Basin rely on its natural resources (especially commercial and subsistence fishing) for much of their sustenance and livelihood.

The offshore area of the North Aleutian Basin is considered to have important hydrocarbon reserves, especially natural gas (Sherwood et al. 2006). However, concerns about the impacts of oil and gas development on ecological resources of Bristol Bay and the economically important commercial fishery prompted Congress to impose a moratorium on oil and gas development in the North Aleutian Basin, and in 1998 President Clinton withdrew the area for commercial leasing until 2012. Although Congress had imposed moratoria on oil and gas activities in the North Aleutian Basin from fiscal year (FY) 1990 through FY 2003, it discontinued the yearly moratorium in FY 2004. MMS held the last lease sale in the North Aleutian Basin in 1988, which resulted in the issuance of 23 leases at the time.

In 2006, Alaska’s Governor Frank Murkowski and other local government and Native Alaskan leaders expressed support for modifying the Presidential withdrawal in the North Aleutian Basin. Also in 2006, the MMS released the draft proposed program, Outer Continental Shelf Oil and Gas Leasing Program: 2007-2012 and an accompanying draft programmatic environmental impact statement (EIS). The draft proposed program identified two lease sales proposed in the North Aleutian Basin in 2010 and 2012, subject to restrictions. The area proposed for leasing in the Basin was restricted to the Sale 92 Area in the southwestern portion. On January 9, 2007, the President modified the 1998 withdrawal to allow leasing in the Basin.

Future leasing and development decisions will require project-specific environmental assessments that are based on current knowledge of important resources in the North Aleutian Basin. There is concern that relatively few studies of resources in the Basin were conducted after 1992 because of the Congressional moratorium and Presidential withdrawal. It is likely that the status of many resources has changed. New studies may be needed to update previous studies, many of which are now nearly 20 years old. A full range of updated multidisciplinary scientific information is needed that addresses oceanography, fate and effects of oil spills, marine ecosystems, fish, fisheries, birds, marine mammals, socioeconomics, and subsistence in the Basin.

Scientific staff at Argonne National Laboratory (Argonne) were contracted to assist the MMS Alaska Outer Continental Shelf (OCS) Region in identifying and prioritizing information needs related to the North Aleutian Basin and potential future oil and gas leasing and development activities. Identified and prioritized information needs would be used to form the basis of inventory, monitoring, and research planning in the Basin. The overall approach focused 


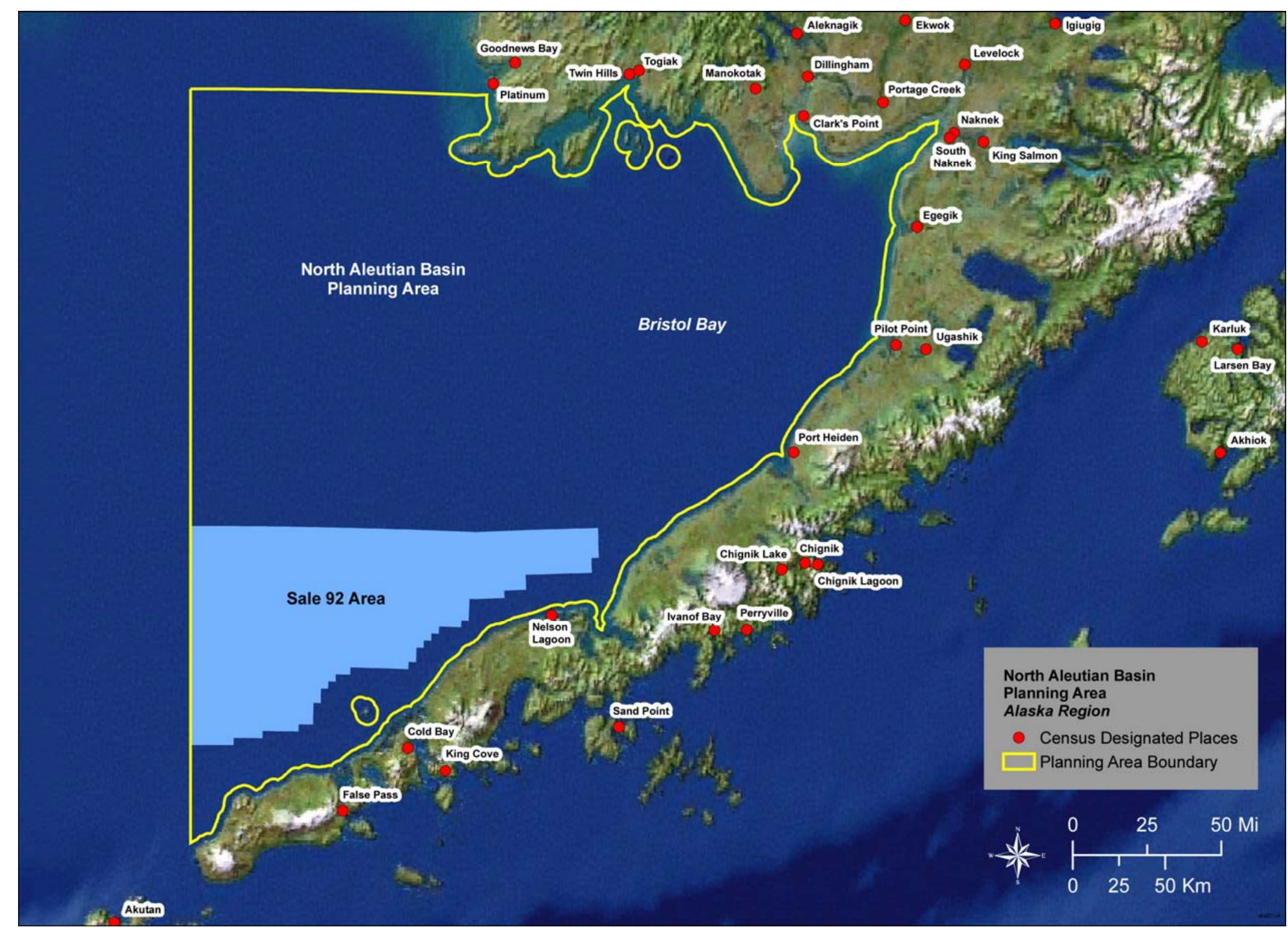

FIGURE 1. North Aleutian Basin Planning Area and the Sale 92 Area. 
on three tasks: (1) identification and gathering of relevant literature, (2) synthesis and summary of the literature, and (3) identification and prioritization of information needs.

This report presents a summary of MMS's North Aleutian Basin Information Status and Research Planning Meeting. Prior to the meeting, Argonne staff gathered the literature relevant to the Basin that had been authored over the last 10 years (1996 through 2006) and developed a database of that literature for use at the meeting. A synthesis report of this literature will be issued separately from these proceedings. 


\section{MEETING DESCRIPTION AND APPROACH}

The North Aleutian Basin Information Status and Research Planning Meeting was held in Anchorage from November 28 through December 1, 2006. Scientists and stakeholders discussed, identified, and prioritized information needed to support assessments of oil and gas leasing and development in the North Aleutian Basin. The meeting was the primary method used to gather input from stakeholders and identify information needs and priorities for future inventory, monitoring, and research related to potential leasing and oil and gas developments in the North Aleutian Basin. The agenda for the meeting is presented in Table 1.

The purposes of the meeting were to:

- Involve a broad range of stakeholders and scientists in science planning for the North Aleutian Basin;

- Plan early for pertinent studies and research in key disciplines and topics to be sponsored by the MMS Environmental Studies Program;

- Identify recommended studies and preliminary priorities based on involvement of meeting attendees;

- $\quad$ Obtain preliminary assessment from MMS of the feasibility, appropriateness, and scientific value of inventory, monitoring, and research activities; and

- Identify preliminary priorities of feasible studies based on MMS Alaska OCS Region mission relevance, timing needs, scientific quality, cost, and other criteria such as implementation considerations.

Individuals invited to participate in the meeting comprised a mix of 190 research scientists, public agency managers, and stakeholders from local government and commercial fishing, subsistence, tribal, and environmental organizations. Meeting registrants (113 persons) and their affiliations are presented in Appendix A (Table A-1). Of these participants, MMS invited and paid for the travel expenses of 16 local stakeholders from the Aleutians East Borough, Aleutian Pribilof Islands Association, Bristol Bay Borough, Friends of Bristol Bay, and Lake and Peninsula Borough. The affiliations of all meeting registrants are presented in Table 2.

The first day of the meeting consisted of a plenary session in which background information was provided to participants. Presentations covered the objectives of the meeting, an overview of MMS's 2007-2012 program plan, the results of Argonne's literature review, and topical presentations by subject matter experts on oceanography, fish and shellfish populations, federal fisheries, commercial fishery economics, community socioeconomics, subsistence research, seabirds and shorebirds, waterfowl, seals and sea lions, cetaceans, and sea otters and walruses. Subject matter experts were individuals with research experience in the North Aleutian Basin.

The intent of the plenary session was to provide sufficient information to enable meeting participants to identify and prioritize further information needs for the environmental assessments of oil and gas development in the North Aleutian Basin. Synopses of these 
TABLE 1. Information Status and Research Planning Meeting Agenda

\begin{tabular}{|c|c|c|}
\hline Time & Topic & Presenter \\
\hline \multicolumn{3}{|c|}{ Tuesday, Nov. 28: Plenary Sessions } \\
\hline 8:00-8:05 AM & Introduction and welcome & $\begin{array}{l}\text { Cleve Cowles, MMS, Alaska Chief of } \\
\text { Environmental Studies }\end{array}$ \\
\hline 8:05-8:30 AM & $\begin{array}{l}\text { Outer Continental Shelf Oil and Gas Leasing } \\
\text { Program, 2007-2012 }\end{array}$ & $\begin{array}{l}\text { Paul Stang, MMS, Alaska Regional } \\
\text { Supervisor }\end{array}$ \\
\hline 8:30-9:00 AM & $\begin{array}{l}\text { Identifying information needs and research } \\
\text { priorities for the North Aleutian Basin }\end{array}$ & Kirk LaGory, Argonne \\
\hline 9:00-9:15 AM & $\begin{array}{l}\text { Recent research relevant to the North Aleutian } \\
\text { Basin }\end{array}$ & Elisabeth Stull, Argonne \\
\hline 9:15-9:30 AM & $\begin{array}{l}\text { Oil and gas development in the North Aleutian } \\
\text { Basin — an operator scenario }\end{array}$ & Ian Voparil, Shell Oil Co. \\
\hline 9:30-10:00 AM & $\begin{array}{l}\text { Circulation, water mass distribution, and transport } \\
\text { in the North Aleutian Basin }\end{array}$ & $\begin{array}{l}\text { Wieslaw Maslowski, Naval } \\
\text { Postgraduate School }\end{array}$ \\
\hline 10:00-10:15 AM & Break & \\
\hline 10:15-10:45 AM & Fish and shellfish populations and distributions & Mike Sigler, NMFS \\
\hline 10:45-11:00 AM & Federal fisheries in the North Aleutian Basin & Diana Evans, NPFMC \\
\hline 11:00-11:30 AM & $\begin{array}{l}\text { Economics of commercial fisheries in the North } \\
\text { Aleutian Basin }\end{array}$ & $\begin{array}{l}\text { Gunnar Knapp, University of } \\
\text { Alaska-Anchorage }\end{array}$ \\
\hline 11:30-1:00 PM & Lunch & \\
\hline 1:00-1:30 PM & Community socioeconomics & Ed Glazier, Impact Assessment, Inc. \\
\hline 1:30-2:00 PM & $\begin{array}{l}\text { Subsistence research in the North Aleutian Basin } \\
\text { area }\end{array}$ & $\begin{array}{l}\text { Brian Davis, Former ADFG } \\
\text { Subsistence Researcher }\end{array}$ \\
\hline 2:00-2:30 PM & Seabirds and shorebirds & Kathy Kuletz, USFWS \\
\hline 2:30-3:00 PM & Waterfowl & Bill Larned and Chris Dau, USFWS \\
\hline 3:00-3:15 PM & Break & \\
\hline 3:15-3:45 PM & Seals and sea lions & John Bengtson, NMFS \\
\hline 3:45-4:15 PM & Cetaceans & Phil Clapham, NMFS \\
\hline 4:15-4:45 PM & Sea otters and walruses & Angela Doroff, USFWS \\
\hline 4:45-5:00 PM & Concluding remarks, instructions for next day & Kirk LaGory, Argonne \\
\hline
\end{tabular}

Wednesday, Nov. 29, and Thursday, Nov. 30: Breakout Sessions to Identify and Prioritize Future Studies

Purpose: Recommend research to support an assessment of the potential environmental impacts of oil and gas development in the North Aleutian Basin program area on marine, coastal, and human resources

\title{
Breakout Session Topics:
}

Physical oceanography, marine ecosystems, fate and effects of oil spills

Fish and commercial fisheries

Birds

Marine mammals

Socioeconomics and subsistence

\author{
Elisabeth Stull, Argonne facilitator \\ John Hayse, Argonne facilitator \\ John Krummel, Argonne facilitator \\ Ihor Hlohowskyj, Argonne facilitator \\ Larry Gorenflo, Argonne facilitator
}

\begin{tabular}{lll}
\hline Friday, Dec. 1: Plenary Session & \\
8:00-11:00 AM & Working group reports: recommended study topics Argonne facilitators \\
11:00 AM-12:00 PM & $\begin{array}{l}\text { Discussion and adjustment to break-out group Kirk LaGory } \\
\text { reports } \\
\text { Adjourn }\end{array}$ & \\
\hline
\end{tabular}


presentations are provided in Section 3. An audio recording was made of all presentations and discussions in the plenary session.

On the second and third days of the meeting, participants broke into five working groups, each facilitated by an Argonne staff member (Table 1). The five working groups included (1) physical oceanography, ecosystems, and fate and effects of oil spills; (2) fish and fisheries; (3) birds; (4) marine mammals; and (5) socioeconomics and subsistence. Most meeting participants participated in only one of the working groups appropriate to their area of expertise. However, several participants (especially stakeholders) participated at various times in more than one of the working groups. This type of interchange was encouraged. The meeting chair rotated among groups to ensure consistent outcomes and to facilitate communication among groups.

The objectives of each working group were to:

- Review the status of existing information,

- Identify information needs to support future environmental assessment activities in the Basin,

- $\quad$ Prioritize those information needs, and

- Develop proposed study profiles to fill high-priority information needs.

Argonne developed a structured approach using a series of worksheets to guide the working group members in identifying and prioritizing information needs. Some working groups opted to use a different approach or to modify the approach for their particular needs. The progress of each working group was recorded on a laptop computer as the session progressed and projected onto a screen in the front of each room. A more detailed description of the breakout sessions including working group members, process, and findings is presented in Section 4.

On the fourth day of the meeting, facilitators presented summaries of the results of their working groups. A question and answer period and discussion followed the presentations. An audio recording was made of all presentations and discussions on the fourth day. 


\section{TABLE 2. Affiliations of Registrants for the North Aleutian Basin Information Status and Research Planning Meeting}

\begin{tabular}{lc}
\hline \multicolumn{1}{c}{ Affiliation (alphabetical order) } & Number of Registrants \\
\hline Alaska Department of Environmental Conservation & 2 \\
Alaska Department of Fish and Game & 7 \\
Alaska Department of Natural Resources & 1 \\
Alaska Fisheries Development Foundation & 2 \\
Alaska Ocean Observing System & 1 \\
Alaska Oil and Gas Association & 1 \\
Aleutian Pribilof Islands Association & 2 \\
Aleutians East Borough & 8 \\
Argonne National Laboratory & 7 \\
Bering Sea Fisherman's Association & 3 \\
Bristol Bay Borough & 2 \\
Bristol Bay Native Association & 3 \\
Bureau of Land Management & 1 \\
Confederated Salish-Kootenai Tribes of Flathead & 1 \\
Nation & 1 \\
Cook Inlet Regional Citizens Advisory Council & 1 \\
Friends of Bristol Bay & 1 \\
Graystar Pacific Seafood & 1 \\
Impact Assessment Inc. & 1 \\
Lake and Peninsula Borough & 1 \\
Minerals Management Service & 1 \\
National Marine Fisheries Service & 1 \\
National Weather Service & 1 \\
Native American Fish and Wildlife Society & 1 \\
Naval Postgraduate School & 1 \\
North Pacific Fisheries Management Council & 1 \\
Pacific Environment & 21 \\
Private consultant & 1 \\
Sea Star Scientific & 1 \\
Shell Oil Co. & 1 \\
U.S. Department of the Interior & 1 \\
University of Alaska & 1 \\
\hline
\end{tabular}




\section{PLENARY PRESENTATION SUMMARIES}

Synopses of the 16 plenary session presentations are presented in this section. Questions and comments from the audience, if provided, and answers given by the speakers are summarized at the end of each presentation in this section. Biographies of the speakers and their presentation materials can be found in Appendix B.

\subsection{INTRODUCTION ${ }^{1}$}

The Secretary of the Interior issued a new five-year proposed program for 2007-2012 in July 2006. The proposed program tentatively scheduled two sales in the North Aleutian Basin beginning in 2010. Should the final five-year program include such sales, environmental studies may be needed to develop key information that MMS would use in preparing EISs for the sales. The planning workshop is an important step to develop study profiles and to jump-start some key projects.

Supporting MMS studies are needed to help assess the potential environmental impacts of oil and gas development on marine, coastal, and human resources. MMS is looking for studies oriented toward hypothesis testing, relevance to agency decisions, and feasibility of implementation. As MMS proceeds with the five-year program, it will continue to seek broad local involvement and local or traditional knowledge links.

MMS is also interested in recent findings and available knowledge from other research efforts, ongoing or planned, to assure that it does not unnecessarily duplicate the efforts of others, but acknowledges that, in some instances, such duplication may be appropriate. MMS encourages interdisciplinary projects that share logistic expenses and information.

\subsection{OUTER CONTINENTAL SHELF OIL AND GAS LEASING PROGRAM, 2007-2012}

The prime role of the MMS Alaska OCS Region is OCS oil and gas leasing and regulation. To accomplish this, MMS staff provide expertise in marine sciences, environmental assessment, resource evaluation, safety, environmental compliance, and oil spill contingency plans. MMS scientists include specialists in biology, oceanography, social science, mineral leasing, engineering, geology, and geophysics.

Four areas in the Alaska OCS Region are included in the 2007-2012 proposed oil and gas leasing program: the North Aleutian Basin (specifically the Sale 92 Area), Cook Inlet, Chukchi Sea, and Beaufort Sea. Sales in these planning areas are proposed for 2010 and 2012 (North Aleutian Basin); 2009 and 2011 (Cook Inlet); 2007, 2010, and 2012 (Chukchi Sea); and 2009 and 2011 (Beaufort Sea). However, leasing in the North Aleutian Basin is contingent on

1 Presented by Cleve Cowles, Chief of Environmental Studies, Alaska OCS Region, MMS.

2 Presented by Paul Stang, Regional Supervisor, Alaska OCS Region, MMS 
inclusion in the final five-year program, removal of the Presidential withdrawal, ${ }^{3}$ and pre-sale decisions. Milestones in development of an oil and gas leasing program would include:

- February 2006: Draft proposed program (60-day comment period);

- August 2006: Proposed program and associated draft programmatic EIS (90-day comment period);

- April 2007: Proposed final program and final programmatic EIS (60-day waiting period);

- June 2007: Final approval of program plan; and

- July 2007: Current program ends, new program begins.

Within the North Aleutian Basin Planning Area, only the Sale 92 Area is included in the proposed leasing program. The last EIS for leasing in the North Aleutian Basin was completed in 1985, and the last lease sale in the Sale 92 area was held in 1988. The subsequent Congressional moratorium prompted a buy-back of leases and resulted in a cessation of MMS-sponsored environmental studies after about 1995. As a consequence, most MMS-sponsored studies are now about 15-20 years old.

MMS's intends to have a synthesis of existing information completed and scientists start field work in the Basin in the 2007 season in order for MMS to have as much information as possible by the time the draft EIS for the lease sale is initiated in early FY 2008. Due to budget constraints, and as a matter of general policy, MMS does not fund environmental studies in a planning area unless a sale is scheduled in the current five-year program. MMS is also interested in studies to develop information for the final lease sale EIS, for any EISs on specific development plans in the event that a commercial discovery is made, and on the focus of monitoring in the vicinity of tracts and in the specific areas of any proposed development. The timing of information needs would proceed according to the following approximate schedule:

- Autumn 2007: Information needed to start EIS for proposed lease sale in the Basin;

- 2008: General monitoring in the sale area begins;

- 2010: Lease sale occurs;

- 2011 (at the earliest): First exploration well and first discovery;

- 2012 (at the earliest): Information needed to start development and production plan EIS;

- 2012 (at the earliest): Monitoring in the development area begins;

- 2015 (at the earliest): EIS completed, development and production plan approved, project sanctioned;

- 2017 (at the earliest): Development and construction at North Aleutian Basin site begins;

- 2020 (at the earliest): Oil production begins; and

- 2025 (at the earliest): Gas production (liquefied natural gas [LNG] export) begins.

3 Presidential withdrawal of the North Aleutian Basin from MMS's leasing program was subsequently removed in January 2007. 
Public meetings to discuss MMS's proposed program in the Basin were held in the autumn of 2006 in Unalaska, Nelson Lagoon, Sand Point, Naknek, Cold Bay, Anchorage, Goodnews Bay, and Dillingham. Key concerns raised in meetings on the Aleutian Chain included (1) the effects of noise and spills on commercial fisheries, subsistence, endangered and threatened species, and other birds and mammals; (2) impacts to North Pacific right whale (Eubalaena japonica) and Steller sea lion (Eumetopias jubatus) critical habitat; and (3) economic benefits, including jobs and access to fuel.

\section{Questions and Comments from the Audience}

- $\quad$ Question: Is it an anomaly that MMS is going through the planning process for an area that is under a moratorium? Is this the first time this has happened or has it happened elsewhere?

Answer: The North Aleutian Basin is not currently under a moratorium. This is the first time MMS has pursued planning while a Presidential withdrawal was still in place. Prior to this instance, there has never been a situation where planning in a withdrawn area could have occurred.

- Question: The discussion at this meeting presumes the Presidential withdrawal is lifted. Is the information gathered at the meeting and in subsequent studies to be used for deciding whether or not to lease areas and to identify stipulations that should be included in the leases?

Answer: The information would be used to support decisions related to the areas that should be offered for lease and those areas that should be omitted from leasing. The information would also be used to identify the terms and conditions that should be placed on leases beyond those that MMS already has in place.

- Question: Although it is assumed that reserves in the North Aleutian Basin are primarily gas, this would not be known until drilling occurs. Under a typical scenario, would MMS export relatively small amounts of oil?

Answer: Two billion barrels is not a small amount and is sufficient to pay for the cost of infrastructure for its development. MMS presumes most oil would be tankered to the west coast of the United States. If substantial quantities of gas were found in the Basin, it is assumed an LNG plant would be developed on the Alaska Peninsula and LNG would be transported south. If a mix of oil and gas is found, the oil would be developed first.

- Comment: Critical habitat for the North Pacific right whale and Steller sea lion was shown in the presentation, but critical habitat also exists for Steller's eider in Izembek Lagoon and the Port Moller-Nelson Lagoon complex.

Response: The referenced slide was not meant to indicate that these were the only species or resources in the area. It is presumed that those resources and their significance would be identified in the meeting. 


\subsection{IDENTIFYING INFORMATION NEEDS AND RESEARCH PRIORITIES FOR THE NORTH ALEUTIAN BASIN OF ALASKA ${ }^{4}$}

The goal of the North Aleutian Basin Information Status and Research Planning Meeting is to recommend research to support an assessment of the potential environmental impacts of oil and gas development in the North Aleutian Basin Planning Area on marine, coastal, and human resources. Recommended studies would be used to support assessments related to two proposed lease sales, to be held in 2010 and 2012. Each lease sale requires an assessment of the anticipated environmental impacts during different phases of activities: prior to the lease sale, post-lease exploration, and development and production.

The North Aleutian Basin contains critically important resources. The Basin is an ecologically, culturally, and economically important area and supports:

- Important fish and shellfish populations;

- A wide variety of seabirds and waterfowl including critical habitat for the federally listed Steller's eider (Polysticta stelleri);

- Marine mammals, including critical habitat for the federally listed North Pacific right whale, Steller sea lion, and sea otter (Enhydra lutris);

- Coastal communities that depend on the resources of the Basin;

- Cultural resources;

- Important commercial fisheries; and

- $\quad$ Subsistence resources.

Much of the land area adjacent to the Basin is under federal jurisdiction as national wildlife refuges (Izembek, Alaska Peninsula, Becharof, and Togiak National Wildlife Refuges) or within the National Park System (Aniakchak National Monument and Preserve and Katmai National Park and Preserve). Coastal communities adjacent to the Basin include the Aleutians East Borough (including Cold Bay, Nelson Lagoon, and Port Moller), Lake and Peninsula Borough (including Port Heiden, Pilot Point, and Egigik), Bristol Bay Borough (including South Naknek, Naknek, and King Salmon), Dillingham, Twin Hills, Togiak, Goodnews Bay, and Platinum.

Working groups were asked to develop specific study profiles than MMS can use to prioritize and fund study projects in the Basin beginning in FY 2007. Each study profile was asked to contain the following elements:

- $\quad$ Need for study and relevance to MMS mission;

- $\quad$ Study objectives, including hypotheses to be tested;

- Methods;

4 Presented by Kirk LaGory, Argonne, meeting chair 
- Timing, including start date and duration; and

- Cost and level of effort.

Several types of studies should be considered, including existing data sets, resource inventories, trends in status and distribution, targeted research to address topical areas, model development, and database development. When assessing the impacts of oil and gas development, one must consider:

- Activity phase of oil and gas development, including exploration, construction, operations, and decommissioning;

- Activities, such as seismic surveys, drilling, and trenching;

- Impacting factors, such as noise, disturbance of substrate, traffic, and accidents;

- Affected resources, such as species, habitats, economy, and subsistence use; and

- Affected resource attributes, such as species life stage, special use areas, jobs, hunting, and recreational fishing.

One should also view the North Aleutian Basin as a system of interdependent parts and focus on the important parts (resources) of the system that are relevant to an assessment of the impacts of oil and gas activities. It is important for more effective monitoring and research to look for opportunities to identify representative species or groups for study.

Breakout session participants were asked to focus on a series of questions to arrive at study recommendations:

- What aspects of oil and gas development could affect resources in the Basin?

- What are the important resources of concern in the Basin?

- What are the important resource attributes for consideration?

- What are the most important oil and gas impacts that affect resources of concern?

- How well do we understand each resource in the Basin and the potential effects of oil and gas development?

Participants were asked to prioritize resources for study according to ecological value (e.g., importance to system, sustainability of resource or system, and rarity), economic value, and societal or cultural value, and to prioritize impacting factors for study by considering duration, magnitude, and spatial extent of effect, as well as importance of the resource affected.

\subsection{DEVELOPING A LITERATURE DATABASE FOR THE NORTH ALEUTIAN BASIN OF ALASKA}

Recent literature was identified for inclusion in a database to support an assessment of the impacts of oil and gas development on natural, cultural, and socioeconomic resources in the

5 Presented by Elisabeth Stull, Argonne National Laboratory 
North Aleutian Basin. ${ }^{6}$ Many types of references were identified and collected, such as workshop and symposium proceedings, personal Web pages, Web pages of government and nongovernmental organizations, EISs, books and articles reporting research results, regulatory documents, technical reports, newspapers and newsletters, and theses and dissertations.

The literature database was organized into 11 categories:

1. Oceanography (biological, chemical, and physical) and other physical sciences;

2. Other biota and community and ecosystem studies;

3. Effects of oil, gas, and other development;

4. Fish and shellfish;

5. Fisheries;

6. Birds;

7. Marine mammals;

8. Subsistence, traditional knowledge, and other related topics;

9. Socioeconomics;

10. Resource and research planning; and

11. Studies related to regulatory requirements.

References were gathered for the years 1996 through 2006, and there was a relatively even distribution of the number of references published each year. Approximately 1,300 references were found, most in electronic format. Most references were related to marine mammals (25\%), followed by birds (22\%), oceanography (20\%), oil and other development (18\%), and subsistence (11\%). Following is a brief summary of the types of references found in each category.

\section{Oceanography and Other Physical Sciences}

- Dynamics of the Bering Sea and the Bering Sea ecosystem;

- Interactions between oceanographic regions (Bering Sea, Chukchi Sea, Beaufort Sea);

- Currents in and around the Aleutian Chain; and

- Effects of global warming.

Little information was found on Bristol Bay nearshore and benthic and intertidal areas.

\section{Community and Ecosystems}

- $\quad$ Phytoplankton and plankton productivity of the Bering Sea;

- Relationships of groups of organisms to habitats;

- Cumulative impacts;

6 A literature synthesis report will be issued separately from these proceedings. 
- Factors structuring communities and ecosystems;

- Benthic organisms;

- Wildlife studies; and

- Impact of oil spills on communities and ecosystems.

\section{Effects of Oil, Gas, and Other Development}

- Oil spill history and impacts, especially as related to the Selendang Ayu and Exxon Valdez accidents;

- Assessments of oil development impacts;

- Population abundance of birds and mammals after oil spills;

- Effects of disturbance from development activities;

- Collisions, with respect to both birds and mammals; and

- Pollutant concentrations in biota.

\section{Fish and Shellfish}

- Population dynamics;

- Migration;

- Abundance and distribution; and

- Recruitment.

The most studied fish and shellfish species were salmon species, king (Paralithodes camtschaticus) and tanner crabs (Chionoecetes bairdi), Pacific herring (Clupea pallasii), and walleye pollock (Theragra chalcogramma).

\section{Fisheries}

- Stock assessments and recruitment and escapement predictions;

- Fish and shellfish diseases and contamination;

- Effect of other activities on commercial fishing;

- Effect of commercial fishing on birds and mammals;

- Fishery management;

- Regulations; and

- Fishery economics.

Major stocks of interest were salmon, crabs (king and tanner), Pacific herring, and groundfish.

\section{Birds}

- Waterfowl abundance, distribution, and breeding;

- Seabird by-catch; 
- Seabird colonies;

- Effects of petroleum spills;

- Contaminant concentrations and effects; and

- Subsistence harvest.

The most commonly studied bird species were eiders and the Kittlitz's murrelet (Brachyramphus brevirostris).

\section{Marine Mammals}

- Surveys, distribution, abundance, and migration and movement;

- Diet and food supply;

- Impact of human activities;

- Population trends; and

- Subsistence use and traditional knowledge.

The most frequently studied marine mammal species were right, fin (Balaenoptera physalus), and bowhead whales (Balaena mysticetus); walrus (Odobenus rosmarus); sea otter; and polar bear (Ursus maritimus). The geographic areas most studied were the Bering Sea and the North Pacific. Little information was found on marine mammal populations in the immediate vicinity of potential oil and gas development activities.

\section{Subsistence, Traditional Knowledge, and Other Related Topics}

- Subsistence harvest of plant products, fish, birds, and mammals;

- Wild foods identification and use;

- Surveys of subsistence practices;

- Native management of resources important in subsistence;

- Traditional knowledge of resource abundance, trends, and ecology; and

- Regulations.

\section{Socioeconomics}

- Community descriptions, including population, education, income, housing, and government;

- Resource economics;

- Infrastructure development (i.e., harbors and community services);

- Borough and Native governments and corporations;

- Community planning;

- Developing industries; and

- Mineral resources. 


\section{Regulatory Requirements}

- Regulations;

- Regulatory analysis;

- Environmental assessments and impact statements;

- Endangered Species Act (ESA) determinations;

- Critical habitat determinations;

- $\quad$ Recovery plans for endangered species; and

- Biological Opinions prepared pursuant to the ESA.

\section{Research and Planning}

- $\quad$ North Pacific Research Board (NPRB);

- Bering Sea impacts study;

- Western Arctic shelf-basin interaction study;

- Gulf of Alaska Ecosystem Monitoring and Research Plan; and

- Eastern Bering Sea coastal research.

In conclusion, there are many recent studies of the Bering Sea area. Research emphasis has been placed on wider regional issues, global climate change, marine mammal species, waterfowl and protected bird species, fishery biology and fishery economics. Significantly less research emphasis has been placed on areas adjacent to proposed oil and gas development locations and benthic and coastal communities and ecosystems.

\section{Questions and Comments from the Audience}

- Question: In the presentation, it did not seem that there were many references on the Steller sea lion. Is that because most of the Steller sea lion work has been done south of the Aleutian chain?

Answer: No, there have been studies of sea lions and ice seals in the North Aleutian Basin, but not as many as for other species.

- Question: Are there any compendiums or other documents that are critical reading material for participants or others interested in the North Aleutian Basin?

Answer: No, there are not any compendiums available, but the Bering Sea Ecosystem Study has summarized material with an emphasis on oceanographic information. In addition, some available research plans have pulled together relevant material.

- Question: What format is the reference database in?

Answer: The database is available as an Excel spreadsheet with author, date, title, and source. A hyperlink to the actual source material is also provided. 
- Question: Why was the literature review limited to the period of 1996 through 2006? Limiting the search to this time period precludes identification of many of the studies funded by MMS in the 1980s.

Answer: The studies conducted in the 1980s are fairly well known and Argonne was directed by MMS to identify only those references from 1996 and afterwards. Syntheses already exist for earlier studies.

\subsection{POTENTIAL FINANCIAL AND EMPLOYMENT IMPACT FROM THE DEVELOPMENT OF OIL AND GAS IN THE NORTH ALEUTIAN BASIN ${ }^{7}$}

Shell Oil Co. currently envisions oil and gas development in the North Aleutian Basin to consist of offshore drilling production platforms, with product transported via pipeline to a natural gas liquefaction facility on the Alaska Peninsula (e.g., near Sand Point), and LNG transported to the U.S. West Coast market via tanker. Shell estimates that this activity would generate approximately $\$ 12$ billion in federal income tax, $\$ 7$ billion in royalties, and $\$ 850$ million in state and local taxes over the lifetime of the project.

Offshore operations and an onshore LNG facility would create construction and operating jobs. Construction jobs are expected to increase from about 2000 in year 1 to about 5000 in year 4 and subsequently to decline. Operating jobs would be relatively constant over an estimated 25-year period with about 400 workers performing jobs on platforms (including operations and maintenance) and 250 workers at onshore facilities.

To develop its workforce, Shell recruits talent at community and technical colleges and universities, develops a local source of talent by working with schools in areas of operation, and invests in local schools and programs. Shell strives to retain and develop talent and provides both supervisory and technical career paths. include:

The types of jobs directly associated with oil and gas development would typically

- Health, safety, and environment services including spill response and emergency response;

- Well services, including drilling, coring, logging, completion, production, recompletion, and abandonment;

- Platform services, including equipment start-up, maintenance, renewal, and removal;

- Logistics handling, including helicopter, crew boats, and equipment barges; and

- $\quad$ Pipe and materials jobs, including fabrication, transport, loading, installation, maintenance, and removal.

7 Presented by Ian Voparil, Shell Oil Co. 
Shell estimates that for every job directly related to the industry there would be six jobs created in local communities. These include service jobs (e.g., food services, transportation, police, fire fighting, education, and housing) and jobs related to the provision of goods.

\section{Questions and Comments from the Audience}

- Comment: Caution should be applied when applying economic effects of oil and gas development on the Kenai Peninsula to projections of effects in the North Aleutian Basin. There are two significant differences in the nature of the economic impacts that oil leasing in Cook Inlet has had with what we might expect of oil and gas development in the North Aleutian Basin. One key difference is that development in Cook Inlet involved leases of State lands, and the revenues from that development that flowed into State government would be much higher than it would be in the North Aleutian Basin where federal leases would occur. The second difference relates to the extent to which there would be local hires. On the Kenai Peninsula, there is a relatively large percentage of employees that live locally, but a valid question is whether that would occur in an area as remote as the Basin. Oil and gas development in the Basin may create a lot of jobs, but one must be careful about additional multiplier effects that are inferred for the region. Also, one needs to distinguish between local tax revenues that would go to the Aleutians East Borough where most of facilities would be and those that would go to other areas such as the Bristol Bay Borough and the Lake and Peninsula Borough where facilities would not be located.

Response: There was no attempt to mislead the audience, and that is why the projections divided out money vs. potential employment. A part of Shell's corporate culture is local hire and local employment and that would have to be worked out. Cold Bay has 55 residents and it is a community that does not have the infrastructure to support development. One could say that conditions now will affect development potential, but it is also possible that development could help drive economic conditions on the Peninsula.

- Question: The potential development scenario presented is useful in planning for studies. Does Shell have information that they could share on potential exploration especially prelease exploration that might help guide studies?

Answer: Two-dimensional seismic explorations have already been conducted in the Basin and MMS knows of these. The author is unable to share Shell's proprietary information.

- Question: Our organization [Pacific Environment] has had a lot of experience with Shell on Sakhalin Island and we have seen Shell make many of the same promises concerning local gas deliveries, protection of habitat, and benefits for communities. What we have seen is communities experiencing large impacts and Shell ignoring independent scientific panels. We have seen a lot of damage to salmon habitat, critical habitat for whales compromised, and communities compromised. Has there been any change in Shell's corporate culture because of the experience on Sakhalin Island and will Shell be able to ensure that promises to communities are kept and ecologically sensitive development occurs? 
Answer: Shell supports ecologically sensitive development. Shell convened an International Union for the Conservation of Nature panel to review their activities. Have you ever heard of another company doing the same? Shell took their recommendations and relocated a pipeline. Shell hopes to be proactive and participate in these kinds of meetings and remove people's concerns beforehand.

- Comment: There is a revenue sharing program that was included in the Energy Bill of 2005 . Alaska gets $1 \%$ of the total revenue and local governments get $35 \%$ of that. The program is called the Coastal Impact Assistance Program and is administered by MMS.

Response: There is a national program that was started after what happened in the Gulf in 2005. The program provides for resources that are developed offshore to be shared locally. This is an important issue that people in Alaska should support.

- Question: Do you have a methodology for evaluating local employment defined as people who come from the State of Alaska and people who come from the local region? What is the experience regarding local employment in other remote regions (not the Kenai Peninsula, but more third world situations)?

Answer: No, I am not personally aware of such a methodology.

\subsection{CIRCULATION, WATER MASS DISTRIBUTION, AND TRANSPORTS IN THE NORTH ALEUTIAN BASIN-MODEL RESULTS ${ }^{8}$}

A regional model has been developed to predict sea ice dynamics throughout the entire Arctic region. The model is a parallel ocean program coupled with a Hibler-type ocean and sea ice model with a spatial resolution of about $9 \mathrm{~km}$. This model has potential for modification and use in modeling circulation, water mass distribution, and transport (including spilled oil or other contaminants) in the North Aleutian Basin.

For the purposes of modeling processes in the Basin, the model requirements include (1) consideration of inflow through the Aleutian Island passes and outflow through the Bering Strait, (2) a required resolution of 1-2 $\mathrm{km}$ in the horizontal and 1-5 $\mathrm{m}$ in the vertical direction (depth), (3) consideration of mesoscale eddies on the order of 20-50 km, and (4) tidal mixing and residual currents.

Circulation in the Basin is dominated by the Alaskan Stream, Alaska coastal current, and wind forcing resulting from the strength and location of the Aleutian Low. Data from 1979 through 2004 are available to characterize these processes and develop model parameters in the North Aleutian Basin for circulation and total kinetic energy of water movement (seasonal and annual), volume transport, heat flux, salt flux, and freshwater flux.

For purposes of assessing potential environmental effects in the Basin, finer resolution is needed to account for the relatively narrow region of the Alaska Coastal Current (about $20 \mathrm{~km}$ wide), bathymetry of narrow and shallow Aleutian Island passes, and mesoscale eddy fields in

8 Presented by Wieslaw Maslowski, Naval Postgraduate School 
the Gulf of Alaska and southeastern Bering Sea. An important consideration is the ability to model the formation and extent of the "cold pool," a pool of cold water that forms on the Bering Sea shelf when winter sea ice traps cold water in place as ice retreats in summer. The cold pool affects water column stratification, which in turn affects mixing, spring plankton blooms, and biological productivity.

Existing models can predict movement of spilled oil in the area. These models demonstrate the importance of the timing of the spill in terms of the movement of oil and areas affected. Depending on the timing of a spill, currents can either move spilled oil eastward or westward in the Basin.

Limited data exist to refine the model for the Northern Aleutian Basin. Additional observations, especially upstream and within the Northern Aleutian Basin region, are needed for model validation and improvement. The Northern Aleutian Basin is a challenging region for ocean modeling. Regional ice-ocean models exist that have a reasonable capability to simulate the Northern Aleutian Basin mean state and variability. High model grid-cell resolution in horizontal (1-2 km) and vertical (1-5 m) directions is required to realistically represent (1) narrow and shallow Aleutian Island Passes; (2) the shallow Northern Aleutian Basin shelf; (3) the narrow Alaska Coastal Current (about $20 \mathrm{~km}$ wide); (4) mesoscale eddies on the order of 20-50 km; and (5) the Bering Slope Current. Realistic high-resolution interannual atmospheric forcing is necessary and the effect of tides on mixing and circulation should be accounted for.

In developing a physical process model for the North Aleutian Basin, the following limitations and possibilities should be considered:

- Modern computer technology allows for realistic multidecade integrations of the PanArctic region at scales of $10 \mathrm{~km}$ horizontally and $5 \mathrm{~m}$ vertically or better (see Maslowski 2007);

- Multi-decade simulations with prescribed realistic atmospheric forcing allow studying interannual-to-interdecadal variability of ocean circulation and may provide guidance to field programs (Maslowski et al. 2000);

- Limited predictions are possible using models with one-way coupling of the atmosphere to the ice and ocean (Maslowski et al. 2001);

- Decadal hindcasts at an eddy-resolving grid for the North Aleutian Basin are achievable at present; and

- A regional climate model should allow seasonal to annual forecasts.

\subsection{MARINE FISH ABUNDANCE AND DISTRIBUTION IN THE MMS NORTH ALEUTIAN BASIN PROGRAM AREA ${ }^{9}$}

The National Marine Fisheries Service (NMFS) collects and maintains fisheries and fish survey data that are used to assist with fishery management. Over $40 \%$ of the commercial U.S.

9 Presented by Michael Sigler, NMFS 
fisheries catch comes from the North Aleutian Basin, including groundfish, shellfish, salmon, and herring. Much effort is expended to understand the distribution and abundance of these fishery resources. Information pertaining to commercial catches and fisheries within the Basin is collected for commercially important species, and indicates a high level of effort and catch within the Sale 92 Area.

In addition, surveys are periodically conducted to evaluate abundance and distribution of important fishery species within the Basin. Standardized bottom trawl surveys are conducted for a variety of commercially important bottom-dwelling species, including walleye pollock and red king crab. These data indicate high variability in distribution from year to year. Under an ongoing NMFS program, major summer surveys have been conducted using a combination of acoustic and trawl surveys in the water column within the Basin (including the Sale 92 Area) from 1979 through 2006; similar surveys have been conducted in other areas surrounding the Alaska Peninsula, although the period of record is not as long and the seasons may differ. These surveys indicate that, while the distributions of monitored species differ from year to year, there are concentrations of some commercially valuable species in the vicinity of the proposed lease area. Because of this annual variability, single-year surveys would be largely insufficient for understanding the factors that affect distribution and abundance. Surface layer fishery surveys have been conducted annually during the fall for the past 6-8 years and are useful for examining distributions of adult salmon and juvenile pollock.

Additional oceanographic and biological data have been collected during these surveys that help in understanding other facets of the ecological relationships within the Basin. Examples of these data include information about nutrients, primary productivity (chlorophyll a), secondary productivity (zooplankton), and the distribution and abundance of ichthyoplankton (fish eggs and larvae). Distributions of ichthyoplankton collected over a number of years demonstrate that the North Aleutian Basin in the vicinity of the Sale 92 Area supports concentrations of eggs and larvae of walleye pollock and sand lance (Ammodytes hexapterus) as well as other important species.

In order to better understand and predict socioeconomic outcomes of management decisions and changes in the distribution and abundance of fishery resources, NMFS also collects information about communities within the region that rely on fisheries.

While the summer distribution of species in offshore areas is relatively well known (because this has been more fully surveyed for a number of years), information about the distribution of fishes in other seasons and of fish abundance and distribution in nearshore waters in the vicinity of the Sale 92 Area is not well known. Therefore, additional information remains to be collected in order to better understand and predict the potential effects of oil and gas development on the fisheries of the Basin. In addition, information in existing NMFS databases could be made more readily available to researchers through the development of Web-based access. Examples of information needs include:

- Seasonal distribution and abundance of nearshore fish, including information about spawning and juveniles. Ideally this information would include the seasonal use by fish of various types of habitats in areas less than $20 \mathrm{~m}$ in depth. 
- Seasonal distribution and condition of juvenile Pacific salmon and walleye pollock. Information about the distribution of these species outside of the autumn period is not well known, but there are clearly changes from season to season. Acoustically tagged fish could potentially be used to better understand seasonal movements and distributions.

- Ichthyoplankton abundance and distribution in Bristol Bay. This area of the Basin is clearly important to early life stages for many species.

Uncertainties related to the seasonal distribution and abundance of nearshore juvenile fish, including ichthyoplankton should be addressed first.

\subsection{FEDERAL FISHERIES IN THE NORTH ALEUTIAN BASIN ${ }^{10}$}

The Magnusson-Stevens Fishery Management Act established eight regional councils throughout the nation. The North Pacific Fishery Management Council focuses exclusively on Alaskan fisheries. The Council recommends management measures for each fishery in the form of Fishery Management Plans (FMPs). NMFS then develops regulations to implement approved management measures, monitors the fishery, and enforces management measures. The responsibilities of the Council are to prepare a FMP for each fishery under its authority, submit amendments to FMPs as necessary, conduct public hearings on FMPs and their implementation, and review stock assessments and harvest specifications. The Council, composed 11 voting and four nonvoting members, is advised by various committees and advisory panels; public comment feeds into all of these advisory groups.

The FMPs relevant to the Sale 92 Area and the North Aleutian Basin are the Bering SeaAleutian Islands groundfish FMP, the Bering Sea-Aleutian Islands King and Tanner Crab FMP, the Alaskawide scallop FMP, the Alaskawide salmon FMP, and the halibut FMP. Fishing for Pacific salmon is prohibited in federal waters, although it is allowed in state waters. Harvest levels for groundfish within the Basin are set by the Council. For the crab and scallop fisheries, the Council determines the optimum yield and overfishing levels, but the actual harvest levels are set by the state. Harvest levels for halibut are set by the International Pacific Halibut Commission, but the management measures are put in place by the Council.

The Sale 92 Area overlaps with three areas for which groundfish statistics are collected and evaluated. Within this area, there are trawl fisheries for pollock, Pacific cod (Gadus macrocephalus), flatfish (yellowfin sole [Pleuronectes asper], rock sole [Lepidopsetta polyxystra], and flathead sole [Hippoglossoides elassodon]), as well as longline and pot fisheries for Pacific cod. A substantial portion of the overall Bering Sea-Aleutian Islands catch within each of these groundfish categories is taken from these three statistical areas. According to fishery observer data from 2005, a substantial proportion of the fishery effort occurs in the vicinity of the Sale 92 Area for nearly all of these fisheries. The Sale 92 Area is currently closed to commercial halibut fishing.

${ }^{10}$ Presented by Diana Evans, North Pacific Fishery Management Council 
Three shellfish fisheries are concentrated in the vicinity of the Sale 92 Area: the Bering Sea tanner crab fishery, the Bristol Bay red king crab fishery, and the Bering Sea weathervane scallop (Patinopecten caurinus) fishery. The Bristol Bay red king crab fishery occurs primarily in the winter. During the 2005-2006 season, between 1 and 51 vessels participated weekly in that fishery and it is estimated that 16.5 million pounds of crabs (2.5 million crabs) were harvested. The Bering Sea tanner crab fishery was closed from 1997 to 2004 and in 2005 there was no direct overlap with the Sale 92 Area (the fishing occurred farther to the west). The fishing effort for weathervane scallop overlapped with the Sale 92 Area in 2004-2005, although the fishery was closed in other portions of the Basin during that period. Few vessels participate in the scallop fishery in this area; between 2000 and 2005, the meat harvested in this fishery dropped from over 205,500 pounds to just over 10,000 pounds. In 2004-2005, the scallops harvested from the Bering Sea area accounted for approximately $2 \%$ of the overall scallop harvest in Alaska.

\section{Questions and Comments from the Audience}

- Question: The area northeast of Unimak Pass, the area that would overlap with the lease sale area is considered "cod alley," an area fishermen consider the heart of the Bering Sea fishery where $21 \%$ of pollock and $40 \%$ of cod trawls occur. This is the nation's largest fishery. Is there an economic evaluation of the fishery's value?

Answer: The Council has that information, but it was not included in the presentation.

- Question: Why is the halibut fishery closed in the area?

Answer: The area is closed because it is an important nursery area for juvenile halibut.

\subsection{POTENTIAL IMPACTS OF NORTH ALEUTIAN BASIN OIL AND GAS DEVELOPMENT ON COMMERCIAL FISHERIES: WHAT DO WE KNOW? WHAT RESEARCH IS NEEDED? ${ }^{11}$}

Commercial fisheries in the North Aleutian Basin are economically significant, with an annual wholesale value of close to half a billion dollars. However, the fisheries within the North Aleutian Basin are highly seasonal and the catches, production, prices, and value can vary widely from year to year.

Commercial fishing and processing is overwhelmingly the most important private-sector industry of the region. In the small, predominantly native villages, salmon fishing is an important source of income and jobs and several towns within the region have major fish processing industries or support industries that rely upon Basin fisheries. The economic benefits and impacts of the commercial fishery in the Basin also extend outside the region: many of the fishermen are from outside the region and a large share of the processing work force is composed of nonresidents. Most of the processing industry is headquartered in Seattle.

The fisheries that could be affected by oil and gas development in the North Aleutian Basin are diverse and complex. These fisheries occur over a wide geographic area and rely upon

${ }^{11}$ Presented by Gunnar Knapp, University of Alaska Anchorage 
multiple fish species. There are different types of fisheries (commercial, sport, and subsistence) that use a variety of types of fishing vessels (small to very large) and involve participants at various scales (families to large corporations). Management of these fisheries is influenced by various state, federal, and international agencies. As a consequence, the fisheries within the Basin can have economic impacts and importance over a large geographic region extending throughout Alaska and the Pacific Northwest. Potentially affected fisheries of significant economic importance are not limited to commercial fisheries: both the guided sport fishing industry and subsistence fisheries are also of significant economic importance.

The principal commercial fisheries within the North Aleutian Basin are salmon, groundfish, and shellfish, although other types of fisheries are also present. The salmon fishery relies on sockeye (Oncorhynchus nerka) and chinook salmon (Oncorhynchus tshawytscha). In Bristol Bay, salmon are commercially taken using drift gillnets and set gillnets; purse seines are utilized in addition to gillnets in other areas along the north Alaska Peninsula. The salmon fishery is managed by the Alaska Department of Fish and Game (ADFG), following policy established by the Board of Fisheries. The groundfish fishery is under federal management (policy set by North Pacific Fishery Management Council and administered by NMFS). The principal species captured in the groundfish fishery include pollock, Pacific cod, and sole (including yellowfin, flathead, and rock sole). They are captured using trawls, longlines, and fishing pots. Shellfish fisheries in the area are for scallops (principally weathervane scallops) and crab (primarily red king crab). The scallop fishery is managed by the federal government, whereas management of the crab fishery has been delegated to the state by the federal government.

Oil and gas development within the North Aleutian Basin could affect fisheries in a number of ways. Probably the most significant and wide-ranging impact would occur in the event of an oil spill. The level of impact would depend on timing, size, and location of the spill, as well as weather conditions. The economic effect of an oil spill would vary depending on which fisheries were impacted, and different types of effects (e.g., acute vs. chronic) could occur over different time scales.

Other aspects of oil and gas development could also affect fisheries. Some of these impacts are probably more likely to occur, but would probably be smaller in scale and easier to assess than impacts from oil spills. For example, development of infrastructure such as placement of drill rigs, oil platforms, pipelines, roads, ports, airstrips, and energy facilities could affect fisheries by creating navigational hazards or causing some areas to be closed to fishing. Additional marine traffic could similarly create navigational hazards or cause some areas to be closed to fishing. Increased population growth could lead to an increased demand for sport fishery resources.

Oil and gas development could also positively impact fisheries: for example, development of infrastructure could reduce transportation and energy costs for fishermen and processors and increased tax revenues could lead to improvements in fishery infrastructure.

It can be difficult to measure the societal importance of fisheries. Different fisheries are important to different individuals, communities, and regions in different ways. Regardless, the 
relative ranking of societal importance or economic importance among fisheries would not be the same for all measures. Selected economic measures of societal importance of fisheries could include those used to describe gross revenues (e.g., ex-vessel value, processing value-added, or support-industry income), net economic benefit (e.g., harvester net income, processor profit, or support industry profit), participation (e.g., number of persons working in harvesting, processing, and support industries), employment (e.g., person months or person years worked for harvesting, processing, and support facilities), and tax revenues.

The data needed to evaluate many of the potential measures of societal or economic importance are limited and data availability differs among fisheries and with the agency responsible for managing the fishery. Such evaluations are further complicated because the economic importance of Alaska fisheries extends far beyond the regions in which the resources are located: many fishermen and processing workers come from other regions, fishing boats and processing plants are often owned by people from other regions, and processing and support industries are often located in other regions. It is generally easier to measure the aggregate importance of fisheries than to evaluate their importance to particular regions or communities. The available economic measures of societal importance of fisheries that might be affected by oil and gas development in the North Aleutian Basin are limited, particularly measures of importance to particular regions or communities. The simplest measures of economic importance, and those for which data are most readily available, are ex-vessel and wholesale value. As a very rough rule-of-thumb, these fisheries have a combined annual ex-vessel value of about $\$ 200$ million and an annual wholesale value of about $\$ 450$ million. Values may be significantly lower or higher in some years.

In most of the major fisheries, the majority of permit holders live outside the region or outside of Alaska. ${ }^{12}$ For example, in 2004 approximately 23\% of the permit holders for the Bristol Bay drift gillnet fishery for salmon were from within the region, about $25 \%$ were from other areas of Alaska, and approximately 52\% were from other states. For the Bristol Bay set gillnet salmon fishery, 39\% of permit holders were from within the region, 31\% were from other areas of Alaska, and 30\% were from other states. For the Bering Sea red crab fishery, 29\% of permit holders were from Alaska, compared with 71\% from other states.

To understand the potential impacts to fisheries of oil and gas development in the North Aleutian Basin, a number of questions need to be addressed:

- First, the location, timing, and other specifics regarding oil and gas development scenarios must be known. With this information, the potential for spills can be evaluated by considering the probability of spills of different volumes and for different times of the year. Spill trajectory modeling can then be conducted to evaluate the probabilities that spilled oil would reach particular locations and that the spill would cause the closures of specific fisheries.

\footnotetext{
12 Statistics from the Alaska Peninsula maintained by the State of Alaska Commercial Fisheries Entry Commission suggest that the percentage of permit holders from outside the region is lower than the Bristol Bay statistics presented by Dr. Knapp.
} 
- The probability of long-term effects on fishery resources also needs to be addressed. With this information, the effects on catches and prices would need to be evaluated, along with the overall aggregate economic effects and the distribution of effects within the region.

The answers to many of these questions are dependent upon answers to other questions and the level of uncertainty increases with each question that needs to be answered. Currently, we are not able to make specific or probabilistic predictions regarding development scenarios, the potential for spills, spill trajectories, the probability of fishery closures, the effects of spills on specific resources, effects on catches and prices, and the resulting economic effects. However, the ability to make predictions will likely improve with targeted research. Currently, any estimates of the potential spill-related economic effects of oil and gas development in the North Aleutian Basin on fisheries will be highly uncertain.

\subsection{COMMUNITY SOCIOECONOMICS: NORTH ALEUTIAN BASIN ${ }^{13}$}

This presentation discussed previous MMS socioeconomic research conducted in the North Aleutian Basin, and gave a theoretical orientation for further research in advance of prospective OCS development in the region. Impact Assessment Inc.'s early work in the Basin, now 25 years ago, included a 20-year forecast of socioeconomic conditions in the absence of OCS development. The work was intended as a baseline against which development scenarios and OCS-related socioeconomic change could be assessed; forecasts were based on systematic ethnographic work in communities in the Aleutians East Borough and points west. Similar work was undertaken by Impact Assessment Inc. in Bristol Bay and other areas potentially affected by prospective OCS industry activity.

The research was organized to enable assessment of long-term social change both with and without OCS development. Three components were involved:

1. OCS development assumptions and scenarios based on industry needs and interests;

2. Baseline social, cultural, and economic conditions against which OCS-related changes could be assessed while controlling for other sources of change; and

3. Potential socioeconomic effects of OCS development at state, regional, and local levels.

A systems modeling approach was used to assess relationships between social structural aspects of the communities and agents or forces of change. The approach was applied along many dimensions: ecology, demography, economics, sociopolitics, social networks, education, health care, and religion. It was attentive to factors such as economic stratification, the effects of external revenue on subsistence practices, and intraregional variation in effects of involvement in commercial fisheries.

At the time, the Alaska Native Claims Settlement Act was relatively new and a newer economic order was developing; commercial fisheries were growing and limited-entry fisheries were being introduced; technology was improving the efficiency of exploitation of natural

${ }^{13}$ Presented by Ed Glazier, Impact Assessment Inc. 
resources. The dominant source of change was projected to be a growth of commercial fisheries and closer integration of the local indigenous society with more formalized systems of social and political interaction. This led to forecasts (working hypotheses) that then-current trends of social change would extend into 2002 even in the absence of OCS development.

Several hypotheses were generated in 1982 about the communities in the vicinity of the North Aleutian Basin, as follows:

- Commercial salmon resources would increasingly constitute an important basis of social and economic change.

- Growth of nonindigenous populations would be less significant than other projections were indicating, due in part to the effects of the Alaska Native Claims Settlement Act and limited-entry fisheries.

- Increased income and predominance of the cash economy were seen as likely, but class dichotomization would occur where involvement in commercial fisheries was mixed.

- Increased correlation between income, economic wealth, and political power would be likely.

- Social and economic interaction and political structures in indigenous communities would become more formalized.

- Traditional means of subsistence would decline given increasing availability of imported goods.

- Adoption of "mainstream" material and social values would accelerate at the expense of traditional orientations.

In short, there was emphasis on probable responses to exogenous social and economic sources of change, and the prediction was made that integration of traditional indigenous and capitalist American-Alaskan societies was inevitable. While some of the hypotheses can now be seen as valid, there is much depth to the story, and detailed ethnographic work would aid in adequately assessing social change in the region since 1982. This would be highly instructive given ongoing potential for OCS development and the associated introduction of new agents and forces of change in this unique region of Alaska.

Given lessons that have been learned since 1982, future analysis is likely to indicate that traditional Unangan, Alutiiq, and other Alaska Native values and lifeways are being enacted with more resilience than was hypothesized. The authors recognized the complexity of social change and the probability that indigenous residents would retain individual and collective identity. Indeed, it is possible to accommodate exogenous forces and factors of change without fully adopting them or sacrificing identity, and many would argue that Unangan and Alutiiq identities are most durable. In fact, indigenous societies have persisted for millennia in Alaska despite a range of challenging factors. Cash and capital are now clearly seen as enabling subsistenceoriented lifeways and associated cultural practices. These aspects of life are not mutually exclusive. 
But one should not infer that these differing ways of life are typically compatible or that attending to traditional lifeways is easy given the pressures of modern societies. In fact, a conundrum is often generated. That is, cash is required in the modern context, but in the absence of opportunity it is not easily acquired, particularly if one highly values subsistence practices and associated traditional cultural lifeways. As such, forms of economic opportunity that readily enable rather than obviate Alaska Native cultural traditions and practices are typically highly desirable to the practitioners.

Understanding the aforementioned conundrum and indigenous interests and the way these have played out over time in the North Aleutian Basin are critically important dimensions of social analysis to be considered in advance of potential OCS development or any other sources of planned change in the region. This is particularly important given the large percentage of Alaska Natives living in the region, the local importance of commercial fisheries, extensive outside participation in the fisheries, and the paucity of other employment alternatives.

The likely community-level social and economic effects of oil and gas development in the Basin cannot be immediately analyzed or answered. Although recent social research in the region has covered a broad geographic area (e.g., NMFS fishing community research), its depth of coverage has generally been limited to specific programmatic needs that yield information that is useful but inadequate for generating sufficient understanding of socioeconomic change and its correlates.

Comprehensive social assessment would require work at the level of detail previously conducted for MMS in the region and careful monitoring of select social and economic variables and indicators over time. Logically, the research would address the nature of participation of indigenous and nonindigenous residents in predominant and subsidiary industries in the region; the potential nature of their involvement in, or interface with, prospective oil and gas industry activity in the Basin; and the dynamic interactive effects of such participation on involvement in traditional cultural practices.

Finally, future assessment must be designed so that the effects of other sources of change (e.g., salmon abundance or lack thereof, or opportunities associated with the proposed Pebble Mine) are analytically controlled for, thereby enabling measurement and adequate understanding of the potential (or actual) local and regional social and economic effects of specific industry actions in the Basin. This is increasingly challenging given that many sources of change are now seen as global in scope and effect.

Effective social assessment will also need to address the potential for spatial conflict and competition between local (indigenous or nonindigenous) fishing interests and the interests of the oil and gas and other maritime industries potentially active on or adjacent to the Basin. This would also require assessment of the larger systems of navigation and maritime traffic through Unimak Pass and elsewhere in the region.

In conclusion, various social science research projects have been conducted in the North Aleutian Basin over the last decade, but the detailed descriptive and theoretically based research that enabled MMS to comprehensively characterize socioeconomic and sociocultural aspects of 
life in the North Aleutian Basin in the early 1980s has not yet been replicated in the region, leaving a series of important hypotheses not fully tested. By comprehensively revisiting old and new socioeconomic variables and theoretical perspectives in advance of prospective further social change, analysts would be able to continue the long-term systematic research begun in the region in the 1980s, and in so doing (1) advance understanding of the human implications of oil and gas development scenarios in the Basin, (2) satisfy National Environmental Policy Act (NEPA) and Outer Continental Shelf Lands Act-related social-analytical mandates, and (3) generate sufficient information for developing policy that could serve to enhance the life experiences of persons residing in adjacent communities.

\section{Questions and Comments from the Audience}

- Question: Has an evaluation been conducted of lessons learned from the effects of the Selendang Ayu grounding on local native jobs?

Answer: The author was involved in conducting interviews of local residents after the accident. The results will be developed into a report that focuses on local reaction to the accident and its effects on subsistence activities.

- Question: Is there a link between that event and the perception of the risk of Outer Continental Shelf development?

Answer: Yes.

\subsection{SUBSISTENCE RESEARCH IN THE NORTH ALEUTIAN BASIN ${ }^{14}$}

Subsistence is a legally defined harvest or use that includes any rural Alaskan harvest, customary harvests, and the cultural values related to harvest. Alaska native cultural groups involved in subsistence in the Basin include (1) Yup'ik Eskimo in Goodnews Bay and Togiak; (2) Alutiiq (Aleut) in King Salmon and Chignik; (3) Unangan Aleut in Unalaska and False Pass; and (4) Athabaskan Indian in Pedro Bay and Naknek. Major subsistence resources in the Basin include salmon, halibut, whitefish, herring and herring roe, smelt (family Osmeridae), cod, dolly varden (Salvelinus malma), clams, tanner crab, king crab, caribou (Rangifer tarandus), moose (Alces alces), harbor seals (Phoca vitulina), sea lions, beluga whale (Delphinapterus leucas), ducks, ptarmigan (Lagopus spp.), sea gull eggs, beaver (Castor canadensis), berries, and vegetation.

Subsistence research in the North Aleutian Basin is conducted by government agencies, Alaska Native organizations, and independent contractors and has covered a variety of topical areas including (1) subsistence foods safety; (2) subsistence traditions, customs, and education; (3) subsistence land use mapping; and (4) subsistence harvest assessment.

Government agencies conducting subsistence research in the Basin include:

- $\quad$ ADFG Division of Subsistence;

${ }^{14}$ Presented by Brian Davis, Former Program Coordinator, ADFG, Division of Subsistence 
- ADFG Division of Commercial Fisheries;

- U.S. Fish and Wildlife Service (USFWS) migratory birds, marine mammals, and subsistence divisions; and

- NMFS.

Alaska Native organizations conducting subsistence research in the Basin include:

- Bristol Bay Native Association,

- Aleutian Pribilof Islands Association,

- Alaska Native Harbor Seal Commission,

- The Alaska Sea Otter-Steller Sea Lion Commission,

- Aleut Marine Mammal Commission, and

- Qayasiq Walrus Commission of the Bristol Bay Native Association.

Independent contractors conducting subsistence research in the Basin include:

- Steve Braund and Associates;

- Herbert Maschner, Idaho State University;

- Robert Wolfe and Associates;

- University of Alaska, Institute of Social and Economic Research; and

- The Nature Conservancy.

Subsistence harvest data are available from:

- ADFG Division of Subsistence: community studies - baseline and directed;

- ADFG Division of Commercial Fisheries: Bristol Bay salmon permit data from 2003;

- NMFS: subsistence halibut harvest by community, 2003-2004;

- Alaska Native Harbor Seal Commission: marine mammal harvest by community from 1992 to 2004; and

- USFWS: migratory bird harvest, 2004, 2005 (not yet available).

The following Web sites provide information on subsistence in the region:

- ADFG Division of Subsistence: www.subsistence.adfg.state.ak.us

- Aleut Marine Mammal Commission: www.aleutmarinemammals.com

- Alaska Native Harbor Seal Commission: www.harborsealcommission.org

- Alaska Native Knowledge network: www.ankn.uaf.edu

- The Alaska Sea Otter-Steller Sea Lion Commission: www.seaotter-sealion.org

- Aleutian Pribilof Island Association: www.apiai.org

- Bristol Bay Native Association: www.bbna.com 
- NMFS subsistence halibut fishing: www.fakr.noaa.gov/ram/subsistence/halibut.htm

- USFWS Subsistence Management: alaska.fws.gov/asm/home.html

\subsection{BRISTOL BAY-NORTH ALEUTIAN BASIN SEABIRDS AND SHOREBIRDS ${ }^{15}$}

Bristol Bay is a critically important area for shorebirds. Up to one-third of the world's population of the bar-tailed godwit (Limosa lapponica) uses Egegik Bay in the autumn, and the only nesting area for a subspecies of marbled godwit (Limosa fedoa) is found in the Bristol Bay Lowlands. More than 300,000 shorebirds, primarily dunlin (Calidris alpina), were counted during aerial surveys of Alaska Peninsula estuaries in 1999. The area serves as a migration corridor and filling station for shorebirds. Western Hemisphere Shorebird Reserve Network sites are located along the Alaska Peninsula and most are considered of hemispheric importance: that is, they support at least 500,000 shorebirds annually or at least $30 \%$ of the biogeographic population of a species.

The Bristol Bay area also supports important seabird colonies. Thirty colonies exist within the North Aleutian Basin with over 60,000 breeding seabirds occurring within the colonies. Forty-four colonies exist between the lease area and Cape Newenham, with over 900,000 breeding seabirds. Although 26 species occur in these colonies, most of the seabirds are common murres (Uria aalge), black-legged kittiwakes (Rissa tridactyla), and tufted puffins (Fratercula cirrhata). Selected colonies are monitored annually or every few years. Others are censused opportunistically. Monitoring is used to determine productivity, breeding chronology, diet, and population trends. These data are maintained by the USFWS.

Many of the seabirds in the Basin do not breed there, but instead feed in the area during the summer months. These species include albatrosses from Hawaii and Japan and shearwaters from New Zealand and South America. Albatrosses (including the Laysan albatross [Phoebastria immutabilis] and endangered short-tailed albatross [Diomedea albatrus]) wander into the Bristol Bay area and concentrate their feeding activities in the Aleutian passes. In fact, Unimak Pass and other Aleutian passes attract millions of feeding birds of a variety of species annually. Movements of the short-tailed albatross throughout the Bering Sea have been determined using satellite telemetry, and these data indicate the species concentrates activity along the Aleutian Chain and occasionally within the open waters of the Basin.

Seabird surveys have been conducted at sea opportunistically on ships traveling through the area for other purposes. Data from these surveys are kept in the North Pacific Pelagic Seabird Database (NPPSD). Most data were collected under the auspices of the Outer Continental Shelf Environmental Assessment Program between 1974 and 1984. Data-collection coverage in the Basin varies seasonally, but is best in the summer; relatively few transects have been conducted during the winter and spring. In 2006, the NPRB provided funding to the USFWS to conduct atsea seabird surveys and to update the NPPSD. Funding covers surveys through 2007; the USFWS intends to seek funding to continue transect data collection. Species commonly

${ }^{15}$ Presented by Kathy Kuletz, USFWS 
observed at sea have included a variety of shearwater species, puffins, and auklets. Other species observed include loons and murrelets, including the Kittlitz’s murrelet.

\subsection{BRISTOL BAY-ALASKA PENINSULA: AVIAN CROSSROADS AND DESTINATION $^{16}$}

Why are there so many birds in the Bristol Bay-Alaska Peninsula area? This area represents a convergence of migratory pathways, and individuals of many species breeding in the Arctic funnel through this region. The area, especially the Alaska Peninsula, has significant food resources, including nutrient-rich estuaries; eelgrass beds; and anadromous fish, marine fish, and invertebrate food resources. It has the most northern ice-free coastal habitats in winter, and the area is remote with a low-level of human disturbance. The importance of the area to birds has been recognized through a variety of special habitat designations including:

- 23 Bering Sea Important Bird Areas;

- Six hemispheric and one international Western Hemispheric Shorebird Reserve Network sites;

- Five state critical habitat areas "essential for wildlife and fisheries resources";

- Three Steller's eider critical habitat units within the North Aleutian Basin planning area and two in adjacent areas

- One spectacled eider (Somateria fischeri) critical habitat unit adjacent to the Basin;

- Two national wildlife refuges;

- Two state game refuges; and

- The first Ramsar Convention Site (Izembek Lagoon) in the United States that represents a "wetland of international importance."

A wide variety of data on waterfowl of the area are available, including USFWS aerial surveys conducted during spring staging, winter, molting, and fall staging; many estuarine studies that collect some data on birds (e.g., marine ecology, abundance, biology, disturbance factors of waterbirds); and several radiotelemetry studies using both VHF and satellite receivers.

Waterfowl are vulnerable to a variety of impacts. Molting birds have high nutritional requirements, limited mobility, and are easily stressed by disturbance. Migration bottlenecks force many birds to move through staging areas where they could be exposed to oil or fuel spills, or other contaminants. In addition, they form wintering concentrations, when spill response would be most challenging.

The species considered most at risk include a variety of sea ducks (Steller's eider, king eider [Somateria spectabilis], black scoter [Melanitta americana], and long-tailed duck [Clangula hyemalis]), geese (Pacific brant [Branta bernicla], emperor goose [Chen canagica], and cackling Canada goose [Branta canadensis minima]), and other ducks, loons, grebes, and

\footnotetext{
${ }^{16}$ Presented by Bill Larned and Chris Dau, USFWS
} 
gulls that occur in estuaries and along shorelines during spring and fall migrations. The following text summarizes information on several of these species.

\section{Steller's Eider}

- Alaska breeding population is considered threatened under the ESA. The population is considered a "world population of concern."

- $\quad$ Pacific population contains less than 200,000 individuals.

- Maximum population in the Basin is estimated at 137,000 individuals.

- The Basin population represents about $70 \%$ of the Pacific population.

- The species is present in the Basin from August through May.

- Concentration sites include all major Alaska Peninsula lagoons, Chagvan, Nanvak, Goodnews, and Kuskokwim Bays from August through May. Birds use the sites for molting, migration, and wintering.

\section{King Eider}

- Considered a "species of concern" with a worldwide decline.

- Western North America population is about 300,000 to 400,000 individuals.

- Maximum population in the Basin is estimated at 240,000.

- The Basin population represents about $70 \%$ of the Western North America population.

- The species is present in the Basin from August through May.

- Concentration sites include the upper Bristol Bay shoals, mouths of all Alaska Peninsula lagoons, and shorelines throughout the Basin.

\section{Black Scoter}

- Considered a "species of concern” with a worldwide decline, including in Alaska.

- Western North America breeding population is estimated at 200,000 individuals.

- Maximum population in the Basin is estimated at 48,000 individuals, which occurs there during spring migration.

- The Basin population represents about $24 \%$ of the Western North America population.

- The species is present in the Basin from August through May.

- Concentration sites include upper Bristol Bay shoals, most major Alaska Peninsula lagoons, especially Port Moller, and shorelines throughout the Basin.

- Greatest periods of vulnerability include migration (March through May) and molting (August through October).

\section{Pacific Brant}

- Considered an international "species of concern” because there has been an approximate $40 \%$ reduction in population. 
- Pacific Coast and High Arctic population that breeds in Alaska, Canada, and Russia is estimated at 120,000 individuals.

- Maximum population in the Basin is estimated at 95\% of the total population.

- The species is present in the Basin from September through May.

- Concentration sites include Izembek Lagoons and Bechevin, Chagvan, and Nanvak Bays from September through November and April through May.

\section{Emperor Goose}

- Considered an international "species of concern" because there has been an approximate $50 \%$ reduction in population.

- $\quad$ Entire world population is estimated at 80,000 individuals and occurs in western Alaska and Russia.

- Maximum population in the Basin is estimated at 95\% of the total population.

- The species is present in the Basin from September through May.

- Concentration sites include all Alaska Peninsula estuaries and Bechevin, Chagvan, and Nanvak Bays.

A number of significant data gaps are relevant to an assessment of the impacts of oil and gas development in the Basin:

- Information on food resources including quantitative and qualitative data from major coastal and estuarine habitats. Needed data include prey density, distribution, competitors, and contaminants relevant to species of concern.

- Spatial information on the year-round distribution of sea ducks, but especially their winter distribution.

- Relationships of seasonal waterbird distribution and migration to environmental variables, especially sea ice, weather, prey distribution and abundance, and disturbance.

\subsection{IMPORTANT PINNIPED POPULATIONS: NORTH ALEUTIAN BASIN ${ }^{17}$}

Four important species of pinnipeds live in the North Aleutian Basin: the Steller sea lion, northern fur seal (Callorhinus ursinus), harbor seal (Phoca vitulina), and spotted seal (Phoca largha). Critical information gaps concerning pinniped populations and the potential impacts of oil and gas development in the North Aleutian Basin on those populations are (1) distribution and habitats, (2) life history, (3) abundance and trends, and (4) stocks and status.

\section{Steller Sea Lion}

In the North Pacific, the range of the Steller sea lion extends from northcentral California northward to the Bering Straits and the Aleutian Islands, and westward along the Russian coast

17 Presented by John Bengtson, National Marine Mammal Laboratory 
to the Korean Peninsula and Japan. Critical habitat in the North Aleutian Basin includes haulouts along the northern coast of the Basin and a haulout along the Alaska Peninsula immediately south of the Sale 92 Area on Sea Lion Rock and Amak Island. This area also includes a rookery site, while the southwestern portion of the Basin and the Sale 92 Area include critical feeding habitat for this sea lion. Additional haulouts and rookery sites occur farther westward along the Aleutian Islands.

Steller sea lions individually marked as pups on Ugamak Island have been tracked to Sea Lion Rock and Amak Island south of the lease sale area, to a haulout along the northern coast of the Basin, and to haulout and rookery sites on islands in central St. George Basin. Steller sea lions from Sea Lion Rock and Amak Island are thought to travel to these same areas.

Steller sea lions give birth to a single pup (median date June 10). Suckling occurs through 9 months to as long as 2-3 years. Maternal foraging trips may last from 7 to 24 hours. Females reach reproductive maturity at about 4 years of age. Steller sea lions depend on blubber and fur for insulation.

The Steller sea lion population has exhibited a dramatic decline at Ugamak Island since 1969. Regional population trends of the western U.S. stock in Alaska include:

- Eastern Gulf of Alaska: rapid decline in the early 1990s, stable or increasing since;

- Central Gulf of Alaska: steady decline in the late 1950s through mid-1980s, rapid decline in the late 1980s, slower decline from the 1990s to present;

- Western Gulf of Alaska: steady decline in the late 1950s through the mid-1980s, rapid decline in the late 1980s, stable from the 1990s to present;

- Eastern Aleutian Islands: steady decline in the late 1950s through the 1980s, stable from the 1990s to present;

- Central Aleutian Islands: thought to be increasing from the 1950s through the 1970s, rapid decline in the 1980s, slower decline or stability from the 1990s to present; and

- Western Aleutian Islands: rapid decline in the 1980s, slower decline from the 1990s to present.

Critical information needs for the Steller sea lion in the North Aleutian Basin include (1) seasonal movements, (2) seasonal habitat selection and use, and (3) age-specific dispersal patterns. These information needs may be addressed using satellite tagging and resighting of marked individuals.

\section{Northern Fur Seal}

The northern fur seal ranges throughout the North Pacific and Bering Sea. The focus of most of the work discussed here is on the Pribilof Islands and Bogoslof Island. Breeding and pup rearing occurs from June to November, and winter migrations occur from November to June. The National Marine Mammal Laboratory conducted fur seal telemetry studies in 2005. A collaborative project partially funded by the NPRB to look at adult female condition both during 
the nursing period and overwinter coincided with a large project involving investigation of the overwinter behavior of newly weaned pups.

Overwinter movements of adult females indicate the area that is used by fur seals during the winter. Satellite telemetry data from 2002 and 2003 of 13 females tagged at St. Paul Island indicated individuals moving as far south as the central California coast. Tagged individuals departed St. Paul Island between November 20 and 29, and departed the Bering Sea near Unimak Pass between November 29 and January 1.

Northern fur seals give birth to single pup. Suckling occurs through the first 4 months. During this time, maternal foraging trips may last up to 12 days. Females reach reproductive maturity at about 3-4 years of age. This species depends on fur for insulation; because of its fur, the species has a long history of commercial harvest.

Between 1912 and 2006, northern fur seal pup production has exhibited a similar pattern on St. Paul and St. George Islands. Between 1910 and the 1950s, there was a steady increase in pup production. Since the late 1950s and early 1960s, pup production has exhibited a steady decline on these two islands. Pup production on St. Paul Island exhibited a $15.7 \%$ decrease between 2002 and 2004, and a 4.1\% decrease on St. George Island over this same time. The one bright spot in the fur seal situation is Bogoslof Island, where in the summer of 2005 we conducted the first pup survey since 1997 and found a 12\% annual increase. That is interesting and leads us into other research. Much of our work involves the comparison of the demographics at this island with those found on the Pribilof Islands.

Critical information needs for the northern fur seal in the North Aleutian Basin include (1) seasonal movements, (2) seasonal habitat selection and use, and (3) age-specific dispersal patterns. This information could be obtained using satellite tagging.

\section{Harbor and Spotted Seals}

The range of the spotted seal includes the North Aleutian Basin and extends northward into the Beaufort and Chukchi Seas, and westward along the coast of Asia as far as the Korean Peninsula and the Islands of Japan. The harbor seal occurs along both coasts of the Alaska Peninsula and the Aleutian Islands, the North Aleutian Basin, and along the Kamchatka Peninsula and to the islands of Japan. Both species occur in the North Aleutian Basin. Surveys conducted in 2000 reported counts of 500 to more than 2,000 harbor seals at several locations along the coast, while telemetry tracking of spotted seals during this same time showed activity to be largely occurring in the northern portions of the Basin. Telemetry data for both species shows harbor seals to extensively use habitats within Cook Inlet, while spotted seals use habitats north of the Alaska Peninsula and make movements northward through the Bering Straits and to the western Bering Sea.

Spotted seal habitat includes sea ice and land. The spotted seal breeds on sea ice, forming breeding triads from February to May. Pups are born with lanugo (soft wooly hair). This species exhibits long-range movements. Harbor seal habitat includes coastal and insular areas and 
exhibits colonial breeding on land or glacial ice. Breeding occurs between April and July, and pups are born with adult-type pelage. This species exhibits short- and medium-range movements.

Harbor seal abundance has exhibited a decline throughout much of its Alaska range; abundance in the North Aleutian Basin has declined by 58\%. Harbor seals in Alaska have been provisionally grouped into several genetic units, and harbor seals in the North Aleutian Basin may belong to a separate stock.

Critical information needs for harbor and spotted seals in the North Aleutian Basin include (1) seasonal movements, (2) seasonal habitat selection and use, and (3) age-specific dispersal patterns. This information may be best obtained through the use of satellite tagging.

\section{Questions and Comments from the Audience}

- Question: Were the comparative photos that were presented of rookeries taken at the same time each year when the animals would be expected to be in these locations?

Answer: Yes, all photographs were taken in July.

- Question: Did the dates of photographs and subsequent conclusions take into consideration annual changes in temperature? Could it be that animals were elsewhere because of annual differences in water temperature?

Answer: It is unlikely that seals were somewhere else because of water temperature differences. If large numbers occurred elsewhere, they would have been noticed during surveys.

- $\quad$ Comment: One needs to know spatial patterns of resource use to identify where the risks are relative to potential areas of development. In the 1980s, there was a lot of modeling done on oil spill risk for areas where seals and sea lions occurred. One needs to use GIS data for that purpose and to determine acoustic impacts. That information helps in making decisions regarding impacts.

Response: Focusing on seasonal and spatial components on a regional scale is a good approach. Finer details can be evaluated once broad patterns are identified. We really do not know what is going on for the Steller sea lion, spotted seal, and harbor seal in the North Aleutian Basin and Bristol Bay.

\subsection{RIGHT WHALES AND OTHER CETACEANS IN THE NORTH ALEUTIAN BASIN $^{18}$}

Several species of cetaceans occur, at least during some part of the year, within the North Aleutian Basin, including the North Pacific right whale, humpback whale (Megaptera novaeangliae), fin whale (Balaenoptera physalus), and several other cetacean species in the Basin.

18 Presented by Philip Clapham, National Marine Mammal Laboratory 


\section{North Pacific Right Whale}

There are three species of right whale: the North Pacific right whale (Eubalaena japonica), the North Atlantic right whale (E. glacialis), and the Southern Hemisphere right whale (E. australis). The North Pacific right whale, which is critically endangered, is currently recognized to consist of separate eastern and western North Pacific populations.

Right whales belong to a group of planktivorous whales that likely arose in their present form around 8 million years ago. They reach a length of $20 \mathrm{~m}$ and a weight of 106,000 kg. Distinguishing features include a black, robust body lacking a dorsal fin and rough, light colored patches found on the head, chin, jawline, and above the eyes. These patches are collectively known as callosities, which provide habitat for whale lice. Callosities do not change much over the lifetime of an individual and their pattern is used to identify individuals in the population.

Whaling for this species in the north Pacific began in 1835 on the Northwest Ground, and whalers moved into the western North Pacific by 1845. Between 21,000 and 30,000 whales were killed in the 1840s, and by 1849 the population was depleted. Some whaling for this species continued into the early $20^{\text {th }}$ century. This species has continued to decline in abundance since that time. There were approximately 598 sightings of right whales in the eastern North Pacific between 1941 and 1964, but only 82 sightings between 1965 and 1999. This decline in whale abundance is believed to be due, in part, to illegal Soviet whaling activities that killed 372 whales (251 in the Gulf of Alaska and 121 in the Bering Sea) between 1963 and 1967. Soviet whaling activities also killed many whales in the Sea of Okhotsk in the western North Pacific. As a result of these past whaling activities, the eastern stock of the North Pacific right whale is considered the most endangered stock of large whales in the world.

Since 1979, a number of research efforts that are focused on cetacean distribution and abundance have occurred in Alaskan waters, and dedicated surveys documenting right whale presence and absence in the southeastern Bering Sea have taken place since 1998. In addition to aerial surveys in the Bering Sea, marine mammal observers on fishing vessels and National Oceanographic and Atmospheric Administration (NOAA) ships are used to collect sightings under the NMFS Platforms of Opportunity Program. Surveys conducted between 1979 and 2005 have sighted whales within the North Aleutian Basin and in the immediate vicinity of the Sale 92 Area.

An evaluation by Townsend of whaling log data for the North Pacific, north of 40 degrees latitude, indicate a harvest of over 2,000 right whales between 1839 and 1904, with 90\% of the whales caught by 1859, and more than 1,000 of this catch occurring east of 180 degrees longitude. Most of the reported catch was from the Gulf of Alaska and south of the Alaska Peninsula; $90 \%$ of these whales were killed within a 20 -year time period. It is important to note that in densely packed areas such as the Gulf of Alaska, up to $20 \%$ of the catch data may not have been included in the whale log data evaluation. In the Bering Sea, most whaling occurred in August and September, while south of the Aleutian Islands, most of the whaling occurred in May and June and in the Gulf of Alaska in June and July. All of the takes south of the Aleutian Islands occurred in waters greater than 2,500 m deep; at least $80 \%$ of the harvest in the Gulf of 
Alaska occurred at this depth or greater as well, while in the Bering Sea over $90 \%$ occurred in shelf waters less than $200 \mathrm{~m}$ deep.

The greatest change from the 1800s to the 1940s is the number of North Pacific right whales found in slope waters of the southeastern Bering Sea. Also in the 1920s, right whales were taken by shore whalers in the vicinity of Unimak Pass. The right whales in steep slope waters were reported by Japanese catcher boats from 1941 to the early 1960s and six whales were harvested under scientific permit. The illegal Soviet harvest of 121 right whales occurred in the shallow shelf waters just west of Bristol Bay in the late 1960s. The Japanese also reported right whales in shelf waters in the late 1960s but exact locations were not provided. Most of the whales were observed in June and July.

Sighting from 1982 to present have been largely in the eastern Bering Sea (western North Aleutian Basin), although survey efforts have not been extensive in slope waters of the Bering Sea. One survey did explore offshore waters south of the Aleutians, but this occurred in August, which may have been a bit late in the season for detecting right whales because Townsend reported most in May and June and Japanese catcher boats saw almost all in June and July. Most of the recent sightings occurred in July, though sightings were reported as early as April (near Unimak Pass) and as late as October.

Many of the sightings from 1924 to 1967 were along the periphery of the Townsend whaling data. Shore whaling stations on Kodiak Island recorded right whales from May through September, while kills by stations operating in British Columbia near the Queen Charlotte Islands occurred in June. In the early 1960s, Japanese catcher boats reported whales in July and August and three whales were harvested under scientific permit near Kodiak Island.

Soviet whalers illegally harvested 251 right whales between 1963 and 1966 near the Patton Seamount. A few sightings by weather ships and a sighting of about 200 right whales by Soviet vessels (it is not clear if all of these sightings were in the same area) were reported as far south as 50 degrees latitude. Japanese sighting efforts continued from 1967 to 1990 and whales were observed throughout the Gulf particularly near the Queen Charlotte Islands, but exact dates and sighting locations were not provided.

Between 1979 and the present, a group of four right whales were seen very early in the season in March near Yakutat Bay, and one animal near Kodiak in July 1998 and in August 2004. However, survey effort has not been extensive over the abyssal plain of the Gulf of Alaska. The right whales seen off Kodiak were among a large group of humpback whales feeding at the surface.

Acoustic monitoring has detected right whale calls in the eastern Bering Sea and Bristol Bay, and at two locations south of the Alaska Peninsula in the Kodiak area. No calls were detected elsewhere in the Gulf of Alaska or the vicinity of the Queen Charlotte Islands. Right whales have recently been reported in the immediate vicinity of the Sale 92 Area from satellitetracking data from a tagged whale, 2004 acoustic detection data, and encounters with 17 individuals. 
From these sighting and catch datasets, it appears that right whales do not have a particular depth preference. Much of their feeding occurs in the summer months when their primary prey is most abundant. Concentrations of these calanoid copepods are found throughout the Gulf of Alaska, in the steep slope waters of the Bering Sea as well as on the Bering Sea shelf. From the few stomach samples available, right whales appear to be targeting the calanoid species that make up the greatest biomass within these areas, regardless of whether they occur over shallow or deep water.

If right whales opportunistically take advantage of any large concentration of prey and do not appear to prefer inhabiting a particular depth, should the entire Bering Sea and Gulf of Alaska be considered important habitat?

Threats to the right whale may include entanglement with fishing gear and ship strikes. There have been no reported ship strikes and only one entanglement incident, but minimal effort was made to evaluate these threats. Basic research is needed on the abundance and distribution of right whales in the North Aleutian Basin. Because year-round surveys are impractical, this information may be obtained more readily using satellite tagging, acoustic monitoring, ecological studies, and predictive modeling.

\section{Humpback Whale}

There is only one species of humpback whale. It occurs worldwide and is considered endangered. The North Pacific is home to four breeding populations. There is no overall abundance estimate for the humpback whale, but its numbers are clearly on the rise. The North Pacific feeding ground for this species includes the North Aleutian Basin and the western portion of the Gulf of Alaska. In the summer of 2000, the abundance of this whale in the eastern Bering Sea was estimated at 102 individuals.

While humpback whales are present in the Bering Sea, it is not conclusively known whether these animals belong to the Western or Central North Pacific stocks. Between 1999 and 2004, vessel and aerial surveys have reported humpback whales from northern Bristol Bay, near Unimak Pass, north of the Sale 92 Area, and along the southern edge and within the Sale 92 Area.

\section{Fin Whale}

There is only one species of fin whale. Like the humpback whale, the fin whale occurs worldwide and is considered endangered. There is no population estimate for the North Pacific population. Two stocks (Eastern and Western) occur in the North Pacific, and it is not known whether they may be mixing in the Bering Sea. Based on 1999 and 2000 vessel surveys, the population on the southeastern Bering Sea is estimated at 683 animals. Abundance estimates for the eastcentral Bering Sea are nearly five times higher, with most sightings in this area occurring along a zone of particularly high productivity along the shelf break. Between 1999 and 2004, surveys have observed fin whales within the Sale 92 Area, immediately north of the Sale 92 Area, and along the southern edge of the Sale 92 Area. 


\section{Other Cetaceans}

Other cetaceans in the North Aleutian Basin include the Pacific white-sided dolphin (Lagenorhynchus obliquidens), the killer whale (Orcinus orca), the harbor porpoise (Phocoena phocoena), Dall's porpoise (Phocoenoides dalli), the gray whale (Eschrichtius robustus), and the minke whale (Balaenoptera acutorostrata). The North Pacific stock of the Pacific white-sided dolphin is classified as a strategic stock under the Marine Mammal Protection Act (MMPA). The stocks of the other species are not considered strategic. Minke whales have been sighted within the Sale 92 Area, while minke and gray whales have been observed along the southern edge of the Sale 92 Area. The Pacific white-sided dolphin, the killer whale, the harbor porpoise, and Dall's porpoise have been observed from within and along the southern boundary of the Sale 92 Area.

\section{Summary}

Many cetaceans live in the Sale 92 Area. While many occur year round, their occurrence is poorly understood. Of biggest concern are the right whales.

Basic research is needed on the abundance and distribution of cetaceans in the North Aleutian Basin. Because year-round surveys are impractical, this information may be obtained more readily using satellite tagging for right, humpback, and fin whales; acoustic monitoring to evaluate occurrence and changes in distribution and in vocalization rates following seismic or industrial activity; and ecological studies of right whales.

The North Aleutian Basin contains right whale critical habitat and is a feeding ground for several species. Potential development areas likely occur in the migratory path of the large whale species. All three listed whale species migrate through Unimak Pass. It is not known how seismic surveys in the North Aleutian Basin may affect passage through the pass. Closely related bowhead whales are known to divert from their migratory path at received sound levels of 120 decibels, which may occur $80 \mathrm{~km}$ from the seismic source. It is critical to understand the responses of listed species during feeding and migration to better identify mitigation and monitoring requirements.

\section{Questions and Comments from the Audience}

- Question: How many right whales could we afford to lose from this population before driving it into a downward trend?

Answer: No one has determined that number because data are not available, but since there are fewer than 100 animals, and possibly far fewer, we do not want to lose a single animal. Population modeling has been conducted for the North Atlantic population, which contains about 300 animals. That model is somewhat controversial, but suggests that the loss of even a couple of females per year would accelerate a trend towards extinction in less than 200 years. The calculated safe level of removal is zero in the North Atlantic. 
- Question: Are any of the recommended studies of Pacific right whale more important than others?

Answer: No, all of the identified studies are of equal importance.

\subsection{THE NORTH ALEUTIAN BASIN: NORTHERN SEA OTTERS AND PACIFIC WALRUS $^{19}$}

The northern sea otter (Enhydra lutris kenyoni) occurs in nearshore coastal waters of the United States from the Aleutian Islands to California. There are three stocks in Alaskan waters: the southeastern Alaska stock, the southcentral Alaska stock, and the southwest Alaska stock. The southwest Alaska stock occurs from the Aleutian Islands, through the Alaska Peninsula, to lower western Cook Inlet, including the Kodiak archipelago. The area occupied by the southcentral Alaska stock includes Prince William Sound, Kenai Fiords, and Kamishak Bay, while the southeast Alaska stock extends from Yakutat Bay to Prince of Wales Island.

Once the Bering expedition had "discovered" Alaska, sea otters were hunted to the brink of extinction by Russian and, later, American fur hunters. When the species was finally protected by international treaty in 1911, there were only 13 remnant colonies, and it is estimated that only 1,000 to 2,000 sea otters remained worldwide. Six of these remnant colonies occurred within the range of the southwest Alaska stock. In the absence of commercial hunting, the remaining sea otter colonies grew rapidly and began to re-occupy their former range.

Recent surveys indicate that the sea otter population in southwest Alaska has undergone a dramatic decline in the past 10-20 years. Population surveys conducted in 1986 along the northern coast of the Alaska Peninsula in the vicinity of the Sale 92 Area found many offshore concentrations of sea otters. Surveys conducted in 2000 showed a considerable decrease in the abundance of northern sea otters in this area. Also, in 2000, fewer animals were seen away from shore, and higher concentrations were observed in coastal habitats, especially in the vicinity of Port Moller and Nelson Lagoon.

Conservation concerns for northern sea otters include:

- Oil and gas transport and spills,

- Improper waste disposal in nearshore marine waters,

- Chronic disturbance,

- Entanglement in fishing gear,

- Vessel strikes, and

- Disease.

Human activities may affect a variety of sea otter behaviors, including grooming, foraging, or resting. Unlike seals, sea lions and whales, sea otters lack a blubber layer, and maintain their body temperature in the cold waters through the insulation of their fur and a high

${ }^{19}$ Presented by Angela Doroff, USFWS 
metabolic rate (2-3 times the resting metabolic rate of a terrestrial animal). Disturbance of resting behavior may cause sea otters to deplete their energy reserves and thus may affect growth, reproduction, and survival. Changes in sea otter activity patterns may deplete an otter's energy reserves; in areas where food is limited, sea otters may spend $50-60 \%$ of their day foraging. Disturbance may cause exclusion of individuals from preferred resting, foraging, or pup-rearing habitat.

Sea otters are also sensitive to contaminants and waste discharge. Contaminants and waste products such as fish offal may directly cause mortality or may reduce resistance to disease. When pollutants such as oils come in contact with the sea otter's fur, they can foul the fur and reduce its insulating ability. Any pollutant that damages the insulating value of the fur may result in hypothermia and potentially death.

While we know much about the life history of the northern sea otter, there are some important data gaps for the population present in the North Aleutian Basin region. The population surveys conducted in 1986 and 2000 indicate a downward population trend as well as a change in the distribution of sea otters in the vicinity of the Sale 92 Area. The basis of this observed decline and change in distribution is unknown. Habitat use of northern sea otters in this area is also not well understood, especially with regard to seasonal and annual movement patterns and the prey base for this population. The health and condition of northern sea otters in this area is also not well understood. Conservation and management priorities to address these data gaps include:

- Population surveys for sea otter abundance and distribution involving systematic surveys of sea otters in nearshore and offshore habitats;

- Longitudinal studies of sea otter survival, reproduction, and movement involving the use of radiotelemetry studies to assess population demography; and

- Health and condition studies of free-ranging northern sea otters, involving the capture of individuals to assess health, condition, and potential disease agents.

The North Aleutian Basin historically supported the largest populations of Pacific walrus (Odobenus rosmarus divergens) in the world. The population ranges throughout the Bering and Chukchi Seas, occasionally moving into the East Siberian Sea and the Beaufort Sea. During the late winter breeding season, large breeding aggregations of walruses form in the broken pack ice of northwestern Bristol Bay; one of three known breeding grounds of the Pacific walrus population. The specific location of breeding aggregations is thought to vary with sea ice conditions and weather patterns. The number of animals that overwinter in the Bristol Bay region is poorly known. In April and May, female walruses and their dependent young migrate out of the region following the receding pack ice to summer feeding areas in the Chukchi Sea. Several thousand animals, primarily adult males, remain in Bristol Bay through the ice-free season, foraging on rich beds of benthic invertebrates and resting at isolated coastal haulout sites.

The most heavily used coastal haulouts sites in Bristol Bay are located at Round Island (within the Walrus Islands State Game Sanctuary), Cape Peirce and Cape Newenham (located on the Togiak National Wildlife Refuge), and Cape Seniavin on the Alaska Peninsula. Less 
consistently used haulouts form at Cape Constantine, Amak Island, The Twins, Crooked Island, High Island, and Hagemeister Island.

Activity patterns of Pacific walruses include long foraging excursions from the haulouts that may be 4-10 days in duration. Post-trip haulout duration is typically $1-2$ days. Walruses travel up to $130 \mathrm{~km}$ from the haulouts during these foraging excursions. The distance traveled is likely a function of prey density; however, the status of walrus food stocks in Bristol Bay is not known.

Walruses are highly sensitive to disturbance. They often flee haulouts in response to the sight, sound, or odor of humans and machines. Disturbance events occasionally result in animal injuries and mortalities. Because walruses are obliged to haulout to rest between feeding bouts, secondary effects on animal condition may also occur when chronic disturbance events disrupt normal haulout behavior. The potential for long-term displacement of animals due to continuous or regular and frequent disturbances at the haulouts is also of concern. There is some historical evidence of coastal walrus haulouts being abandoned as a result of prolonged or repeated disturbances. The abandonment of preferred haulout locations could displace animals from preferred feeding areas or require them to travel greater distances to reach the nearest refuge.

Little information is available to assess the extent or effects of offshore disturbances to walruses in the Bristol Bay region. Walruses may respond to disturbances by moving away from important feeding areas. Changes in distributions and abundance that prevent a species from exploiting its prey base in the most efficient manner could result in long-term changes in survival and abundance.

Primary conservation concerns associated with oil and gas exploration and development in the North Aleutian Basin and effects on Pacific walrus are:

- Introduction of noise and related disturbance from oil and gas activities that could disturb adults and young in breeding, resting and foraging areas; and

- Exposure of walruses, their habitats, and their prey base to pollutants released by local and distant pollution sources.

Research and monitoring priorities to address data gaps in our knowledge and understanding of the ecology of the Pacific walrus in the Basin, and of how the Pacific walrus population might be affected by oil and gas development in the Sale 92 Area, include:

- Identification and delineation of important foraging areas;

- Investigation of seasonal distributions and haulout use patterns, with emphasis on use of the Cape Seniavin walrus haulout on the Alaska Peninsula;

- Investigation of the responses of Pacific walrus to vessel and aircraft traffic and seismic operations; and

- Modeling of oil spill trajectories related to breeding, feeding, and resting areas and evaluation of potential effects of spills on walruses, prey species, and habitats. 


\section{WORKING GROUP PROCESS AND FINDINGS}

On the second and third days of the meeting, participants broke into five working groups, each facilitated by an Argonne staff member. The five working groups included (1) physical oceanography, ecosystems, and fate and effects; (2) fish and commercial fisheries; (3) birds; (4) marine mammals; and (5) socioeconomics and subsistence. This section summarizes the process and findings of each working group.

\subsection{OCEANOGRAPHY, ECOSYSTEMS, AND FATE AND EFFECTS}

The Oceanography, Ecosystems, and Fate and Effects of Oil Spills Working Group evaluated the knowledge base of studies completed for Bristol Bay and the Bering Sea and recommended a suite of further studies to address deficiencies in information needed to support environmental assessment and decisionmaking for oil and gas leasing. The topic of oceanography included the physical, chemical, and biological environment of open waters. The ecosystems topic included marine, freshwater, and terrestrial habitats of potentially affected areas. Fate and effects included oil and gas exploration, development, and production; transportation of workers, equipment, and petroleum products; and construction and maintenance of infrastructure.

The working group was facilitated by Elisabeth Stull of Argonne. The group included representatives of Aleutians East Borough, EPA, NMFS, MMS, University of Alaska-Fairbanks, National Weather Service, Naval Post Graduate School, and USFWS (Appendix A, Table A-2).

\section{Working Group Process}

At the beginning of the session, participants introduced themselves and gave a brief description of their backgrounds and interests. The moderator gave a presentation on the purpose, goals, and proposed methodology for identifying high-priority studies. Participants then discussed the proposed working group methodology and how it could be adapted for use in the working session. MMS described three phases of environmental review that would be required for potential leasing and oil and gas development: (1) an EIS prior to a lease sale, (2) a post-lease environmental assessment on exploration activities, and (3) an EIS for the development and production plan.

The working group first addressed the definition of impacted resources and resource attributes. Ecosystem resources were easily identified by community name, such as benthos or coastal lagoons. However, the definition of impacted resources in the areas of oceanography and fate and effects was more difficult. In these topical areas, the important environmental elements were best described as a process or a characteristic of the physical environment that either determines fate and effects or supports biological communities. The working group identified 24 key ocean processes, environmental characteristics, habitats, or ecological communities that were to be considered "impacted resources" Table 3 lists these resources and identifies why they were considered important to the group. 


\section{TABLE 3. Affected Resources Identified for Further Evaluation in the Oceanography, Ecosystems, and Fate and Effects Working Group}

\begin{tabular}{ll}
\hline \multicolumn{1}{c}{ Resource } & \multicolumn{1}{c}{ Importance } \\
\hline Water quality & Regulatory and public concern \\
Air quality & Regulatory concern, health \\
Sediment quality & Contaminants, environmental indicator \\
Existing contaminants & Natural and human causes \\
Sediment description & Ecology, fate of contaminants \\
Benthos & Ecology, trophic importance \\
Eelgrass communities & Ecosystem, keystone community \\
Intertidal community & Habitat, ecosystem \\
Terrestrial communities & Habitat disturbance \\
Wetlands & Important habitat \\
Lakes and streams & Habitat disturbance \\
Primary productivity & Food web, trophic importance \\
Secondary productivity & Food web, trophic importance \\
Nutrient dynamics & Crucial process \\
Coastal flow & Crucial process \\
Regional circulation & Crucial process \\
Fronts and stratification & Crucial process \\
Waves & Contributory process \\
Sea ice & Contributory process \\
Tides & Pollutant distribution \\
Storm surges & Contributory process \\
Meteorology & Crucial process; wind circulation \\
Spill occurrence probability & Natural and human causes \\
Geologic hazards & Contributory process \\
\hline
\end{tabular}

The working group attempted to assign priorities to these resources and attributes, but almost all of them were viewed as high priority. Further evaluation by the group was needed to prioritize the resources and attributes. This evaluation first examined the strength of the linkage between the resource and development activity and the relative magnitude of impact. While this first step proceeded smoothly for communities and habitats, the rest of the linkages and resources did not fit neatly into this structure. The affected resources were often linked to a chain of events that resulted in an impact from oil and gas development. For instance, coastal circulation was not seen as being affected directly by oil and gas development activities, but it was a critical element 
in the distribution of spilled oil to marine habitats and species. Because of the web of connections between oil and gas exploration and the rest of the list of affected resources, the linkage evaluation was not useful for many resources listed in Table 3.

The participants discussed different approaches for prioritizing resources and attributes, but decided to proceed directly to determining critical information needs by examining the highpriority environmental impacts of oil and gas activities and high-priority resources. Priority was determined by the magnitude of the effect; spatial extent of the effect; and existence of environmental controls, regulations, and industry practices to mitigate impacts. Both primary and secondary impacts were considered in the working group's evaluation.

\section{Working Group Findings}

Water Quality. There are many potential sources of impacts to water quality from oil and gas development. Activities associated with routine operations are regulated and mitigated by environmental controls at the impact source. Methods of controlling and mitigating the impacts of accidents have been developed and are well described. While site-specific information on water quality in the location of potentially affected areas is not well developed, the mechanisms of impacts of oil and gas development are well known. Impacts from routine operations are tightly regulated and the industry has well-developed control and mitigation practices. However, in the case of an oil spill, the impacts can be far-reaching and difficult to mitigate. These impacts have received extensive study for the Exxon Valdez oil spill; however information is lacking for assessment of oil spills in the area affected by the proposed leasing. The missing information which is important for water quality analysis is baseline information. The working group determined that this information would most likely be developed as part of permitting, and no study profile was developed.

Sediment Quality. While there could be impacts to sediment quality during drilling operations, the working group did not give them a high priority because such impacts would be localized. However, impacts to sediment quality from accidental oil spills could be far reaching. The working group identified critically important information that was needed to assess the potential impact of an oil spill on sediment quality. Baseline characteristics of existing sediment quality in the lease area and other potentially affected areas are a key information need. Although the mechanism and types of impacts to sediment quality are fairly well known, the assessment of the magnitude, duration, and potential mitigation of oil spill impacts would require a description of sediments in the affected area, and that information is currently missing.

Benthic Communities. Benthic communities could be affected both by oil spills and by drilling and trenching. Studies on the Exxon Valdez oil spill have provided information on the impacts of oil spills on benthos in general. However, the benthic communities of potentially affected areas and along transportation routes have been poorly described. There is a critical need for baseline information describing the benthic communities that could be affected by oil and gas development. This is essential data for impact assessment. At a minimum, benthic surveys of the areas of potential lease sales and nearshore environments are needed. 
Eelgrass Communities. Eelgrass communities found in the coastal lagoons are of global importance to migrating waterfowl and shorebirds. Information on the distribution of eelgrass communities and a determination of food web linkages within the eelgrass community are necessary for assessing the primary, secondary, and cumulative impacts of pipeline trenching and oil contamination. Development of potential mitigation procedures also requires this information.

Intertidal Communities. Detailed descriptive information on intertidal communities in the vicinity of the lease-sale area is scarce; however, Environmental Sensitivity Index maps have been developed by NOAA for emergency planning. Intertidal communities could be seriously affected by oil after a spill, and intertidal communities could also be disturbed in the vicinity of pipeline construction. Rocky intertidal areas contain important habitats for marine mammals. While the types of impacts from oil contamination on intertidal communities are known from studies of the Exxon Valdez oil spill, assessment in the proposed lease area requires information specific to the Bristol Bay shoreline.

Terrestrial Communities, Lakes, Streams, and Wetlands. The terrestrial communities, lakes, streams, and wetlands potentially affected either by development of transportation networks or by an on-land petroleum spill in this part of Alaska have not been described in detail. The specific impacts of development of the offshore leases on terrestrial communities, lakes, streams, and wetlands are not known, because information is missing on the details of the location of habitat disturbances by pipeline, road, and other infrastructure construction. Information on habitat descriptions and the locations of onshore activities are judged to be critically important. The working group discussed whether this information need was identified by any other working group.

Primary Productivity. The working group discussed the impacts of oil and gas development on primary productivity and plankton. The highest priority information need identified was related to accumulation of oil at the edge of sea ice. The sea ice edge is an important habitat for marine mammals and sea ducks. While research priorities developed for these animals was the assignment of other working groups, the sea ice edge is also an area of high productivity of marine plankton. The working group identified the study of primary productivity at the sea ice edge as a way to assess the impact of oil contamination.

Physical Oceanographic and Atmospheric Factors. The working group discussed the state of knowledge of physical oceanographic and atmospheric factors that determine the distribution and fate of contaminants (including oil) that could arise from all phases of oil and gas development. Of these factors, regional circulation in the Bering Sea and Bristol Bay during the summer period is the best known. However, regional circulation patterns during the winter are poorly known. Information is also not available on coastal flow and wave patterns in the vicinity of the lease area, fronts, and stratification in Bristol Bay and the Bering Sea, and marine weather in the lease area. All of these factors are essential for modeling the distribution and fate of waterborne contaminants. It is not reasonable to assume that oil release in the marine environment would occur only during clement weather in the summer. Oil releases may be as likely in the autumn and winter when migrating birds are using nearby habitats and sea ice habitats of marine mammals and sea ducks are closer to the lease area. Information to be used to model the fate of 
oil contamination in the autumn and winter is critical. The working group identified the following physical studies as of critical importance:

- Seasonal observation and modeling of coastal flow,

- Description and modeling of seasonal and inter-annual regional circulation,

- Statistical baseline study of waves in the lease area,

- Continued observation of sea ice,

- Determination of tidal exchanges in passes and lagoons, and

- Weather observations at the sea surface in the lease area.

Summary. On the basis of the discussions and findings of the working group, study profiles were developed for physical oceanographic studies and ecosystem studies. Physical oceanographic studies were linked to provide a sound basis for modeling and predicting the fate of oil and other contaminant releases. Ecosystem studies were developed to describe the most poorly known systems, and those that would be the primary receptors of contaminants. The working group developed the following study profiles:

- Modeling of circulation,

- Physical oceanography field program,

- Implementation of a meteorological buoy,

- Mesoscale meteorological modeling,

- Characterization of sediments,

- Characterization of benthic communities,

- Determination of the biological productivity of the sea ice edge,

- Characterization of eelgrass communities, and

- Characterization of intertidal communities.

Individual study profiles are presented in Appendix C (Section C.1).

\subsection{SOCIOECONOMICS AND SUBSISTENCE}

The issues covered under the Socioeconomics and Subsistence Working Group included a broad range of topics related to culture and human society - economic structure, income, pursuit of traditional lifeways, demographics and inmigration, public services, and other social, economic, and cultural attributes. Subsistence discussions focused on the exploitation of natural animal and plant resources harvested for personal use and local exchange. There exists considerable overlap between socioeconomics and subsistence. While the working group attempted to keep topics distinct or separate, it was acknowledged by most participants that it would be virtually impossible to separate certain socioeconomic issues from subsistence, and vice versa. 
Larry Gorenflo of Argonne facilitated the working group discussions. The names of participants and their affiliations appear in Appendix A (Table A-2). The group consisted of about 20 individuals, with people moving in and out of the session over the two days. The working group comprised a broad array of individuals, including several representatives from the MMS who served as observers and who could answer questions on MMS roles and responsibilities related to leasing activities. Representatives from other federal agencies and the state of Alaska also participated. Many individuals who live in the North Aleutian Basin and represent local peoples (including Alaska Natives) attended the working session, and provided some of the most important information in the working group.

\section{Working Group Process}

The Socioeconomics and Subsistence Working Group began working through a series of worksheets designed specifically to guide discussions and develop systematic information on possible impacts of oil and gas development. The group began with a worksheet on impacting factors, in an attempt to identify the consequences of oil and gas development that would affect socioeconomics and subsistence. After a period of discussion and debate, the group decided to revise the original worksheet format for developing study profiles.

The group decided to identify a process to enhance group interaction, facilitate communication, and address data needs while including the views of a diverse group of individuals from a broad range of backgrounds. The working group decided to try to generate discussion by asking each participant their thoughts and ideas on two topics - the important impacts of oil and gas development and the type of information necessary to evaluate these impacts. This process is similar to discussions often held in rural Alaska and was familiar to most working group participants. The group spent the remainder of the first day of the session using this process to discuss subsistence, and decided to focus on socioeconomics during the first half of the next day.

Once the facilitator and group recorded the comments of the group on socioeconomics and subsistence, the group turned its attention toward generating study profiles. The facilitator and a typist recorded information from the group's discussion on a flip chart and on a computer; the latter projected the information onto a screen in front of the meeting room. The group then went through the main headings of a study profile: information needs, total cost, organization conducting the study, description (objectives and methods), and the date information is required. The information for these categories was obtained by drawing upon the information developed during the discussions to outline study profiles for socioeconomics and subsistence.

\section{Working Group Findings}

Subsistence. The main concerns of the working group, expressed particularly by group members who live in local communities, revolved around subsistence. Group members expressed great concern that oil and gas development might have adverse effects on subsistence activities, primarily through affecting the resources themselves, but also through interrupting subsistence harvests (e.g., through noise and additional air and water traffic) and by introducing additional people to the region who might compete for subsistence resources. Several working group 
members stressed the importance of taking explicit steps to ensure that such impacts did not occur, thereby ensuring the continuation of subsistence and the important economic and cultural roles that it plays. The working group discussed and identified the need to verify that mitigation strategies and procedures have been effective in protecting human communities from the adverse effects of oil and gas development on the North Slope of Alaska. The need for such research achieved broad consensus within the group. An MMS annual study plan already includes an active profile for such a study (entitled Aggregate Effects Research and Environmental Mitigation Monitoring of Oil Operations in the Vicinity of Nuiqsut). The working group endorsed that existing study profile rather than develop a new profile on the topic.

Working group members discussed a range of subsistence resources, including marine resources (invertebrates, mammals, and fish), terrestrial mammals, and birds. Although several group members declined to rank one above another, marine resources emerged in the discussions as the most important (particularly fish), followed by the variety of birds that migrate through this region, and then terrestrial mammals. Group members mentioned not only possible oil and gas-related impacts, but also the timing of impacts, such as important bird migration or fish spawning periods.

Working group members noted the need to systematically obtain data to identify current subsistence behavior in the North Aleutian Basin. It was generally agreed that the most systematic efforts to obtain such data were the community surveys conducted by ADFG Division of Subsistence, though some participants questioned the accuracy of certain types of information (such as mapped subsistence use areas) due to a propensity of subsistence practitioners to keep this information secret from others. Group members also mentioned that data obtained by these surveys currently are quite old, thus identifying a need to update past surveys with new efforts to identify current baseline subsistence conditions. Finally, group members recommended supplementing the standard ADFG surveys with additional information, notably information on issues such as sharing resources, the timing of subsistence activities, and how economics of the household affect subsistence activities. These supplemental topics appear in the subsistence study profile presented below.

Socioeconomics. Working group members conveyed major concerns about the socioeconomic impacts of oil and gas development. The main concern, by far, was the potential impact on the fishing industry, which is a major source of income for area residents that already has suffered and is susceptible to impacts. Other issues raised by working group members included the ability of local communities to accommodate an influx of new people (and provide infrastructure and services required by these additional people), the post-oil and gas development period where the added infrastructure remains in local communities (but lacks funding for adequate maintenance), potential impacts on local life of major shifts in the economy, and the need for the oil and gas industry to hire local people not only for lower level jobs, but also for higher level positions.

Working group members generally agreed that much of the necessary data already exist to define socioeconomic baselines for communities in the North Aleutian Basin. Participants suggested that various data sources be considered, emphasizing local communities and the increasingly broad range of data collected on their residents. Once these data are compiled, any shortcomings could be identified with additional information obtained (if necessary) through 
specific studies or surveys. In certain cases, notably the fishing industry and its importance to the region, working group members suggested coordinating socioeconomic data compilation with biological data, to better understand the status and behavior of the resources.

Summary. The Socioeconomics and Subsistence Working Group ultimately generated two study profiles, one for socioeconomics and one for subsistence. In each case, the profiles represented the highest priority issues and were determined necessary for EISs and assessments on leasing, exploration, and development and production activities. The aim of the socioeconomic study profile is to provide a detailed socioeconomic overview (baseline) of key communities in the North Aleutian Basin. The approach recommended is to synthesize existing socioeconomic data, using focus groups for certain types of qualitative data. The basis for the subsistence profile is updating ADFG surveys for key communities. The geographic focus of these updated surveys would be Cold Bay, False Pass, Nelson Lagoon, and three other representative communities to be named later (after further consideration). The full study profiles are provided in Appendix C (Section C.2).

\subsection{FISH AND FISHERIES}

The Fish and Fisheries Working Group addressed the potential of oil and gas development to affect key biological system components of fish and associated food chains and the commercial harvest of fish populations. The working group addressed fish distribution and abundance, data availability, key population issues, and linkages to other ecological resources or systems.

John Hayse of Argonne was the facilitator for this working group. Participants in the working group included representatives from NMFS, USFWS, MMS, ADFG, University of Alaska, Shell Oil Co., Native American Fish and Wildlife Society, Bristol Bay Borough, Aleutians East Borough, Lake and Peninsula Borough, and Bering Sea Fishermen's Association (Appendix A, Table A-2). Attendees also included local residents, commercial fishers and processors, and members of the Alaska Fisheries Development Association, the Alaska Marine Conservation Council, and Pacific Environment. Although there were 18 individuals that participated in most of the working group discussions, other individuals participated as they moved between concurrent working group sessions.

\section{Working Group Process}

The working group used worksheets to focus discussions on the fish and fishery resources within the North Aleutian Basin that were of greatest concern. Worksheets were used to guide discussions and record information from group discussions about the impacting factors associated with oil and gas development that were most likely to affect key resources. The group identified the level of understanding for various resources, as well as the effects of impacting factors on resource attributes. The group discussed and identified the type and coverage of available data, gaps in knowledge, and potential study topics. Finally, the group prioritized potential studies on the basis of the anticipated level of urgency for gathering information prior to oil and gas development and the importance of filling information gaps. 
The working group session began with a brief introduction from the facilitator and a review of the objectives of the meeting as a whole and of the working group in particular. The group used a worksheet to record the results of discussions on impact duration and location.

The working group identified species and their attributes that were at risk from oil and gas development and the specific impacting factors that could affect those resources. In addition, participants discussed the current knowledge of fish and fishery resources (e.g., current condition, distribution, or status) and the degree to which species could be affected by offshore oil and gas development activities.

The group developed a list of potential study topics. To identify studies that should be conducted in the near-term, the working group discussed and developed an overall ranking for the study topics that considered the perceived importance of addressing an information need, the need to collect the information prior to or in the early stages of planning, and the anticipated levels of cost and effort. Perceived importance and urgency were of greater concern to participants than cost and effort.

\section{Working Group Findings}

A concern raised by many working group members was the incomplete understanding of the distribution and abundance of many of the important fishery resources within the North Aleutian Basin. In some cases (e.g., for salmon species) there was relatively good information available for some seasons of the year, life stages, or habitats, but very little information for others. Some information is available on adult salmon spawning migration pathways along the lower Alaska Peninsula and early smolt out-migration. However, where smolts occur outside of the early summer months, whether juvenile salmon inhabit the potential lease area during part of their maturation process, and the routes taken by migrating adults are not known. Knowledge of species distributions and abundance would be needed to better assess potential impacts and as baseline information to conduct monitoring. Collection of this baseline information was considered to be a high-priority item.

Oil and gas development within the Sale 92 Area also has the potential to affect fisheries within a wider geographic area, including adjacent offshore and nearshore marine areas and onshore freshwater areas. For example, impacts to a substantial portion of the adult salmon from specific stocks could result in reduced migration to spawning streams, continued harvest in the mixed-stock fishery, and subsequent long-term reductions in those stocks. This could, in turn, affect commercial and subsistence fisheries and the economies that are supported by the fisheries. There are similar situations with some other important species. For example, it is unknown whether herring stocks on the north side of the Alaska Peninsula differ from stocks on the south side, and, although smelt spawning areas are known, where they occur during other portions of their life history is not. For some species, there is only a general understanding of distribution during a portion of the year. For instance, there is only a limited understanding of adult flatfish location and habitat use in offshore locations during the summer and of forage fish habitat during spring and summer; distributions and habitat requirements during other seasons are not known. As a consequence, the group considered it important to develop adequate baseline information and evaluations of potential impacts for areas extending outside the Sale 92 Area. 
The impacting factor of greatest concern to the group was potential oil spills from development activities. It was recognized that impacts of oil spills would depend on a number of factors, including spill volume, timing, location, and prevailing currents. Thus, it is critical to know which species and life stages are present, their location in the water column, seasonal abundance, and their susceptibility to oil. Tainting and the perception of tainting from an oil spill could have as great or greater impact on the fishery as oil contamination itself. The potential sensitivity of crabs to oil toxicity was of particular concern due to the importance of the crab fishery to local residents.

Concerns were expressed about the effects of seismic surveys on the behavior of species and life stages and on conflicts with fishery activities. In addition, there were concerns about the potential for invasive species to be introduced by oil and gas development activities and concerns that such introductions could lead to ecosystem-level changes. An ecosystem model could useful in understanding these sorts of effects. Economic aspects of fisheries, associated with both subsistence and commercial fishing, also were discussed, although it was assumed that identification of necessary studies would be undertaken by the Subsistence and Socioeconomics Working Group.

The working group specifically discussed opportunities to collect fisheries information in conjunction with other resource studies and noted that coordinating these studies could improve the usefulness of the information. For example, opportunistic identification and sampling of forage fish at locations with concentrations of predators, examination of predator diets, and using satellite tags on predators to locate and track seasonal concentrations of prey fish species could result in a better understanding of the role of forage fish within the North Aleutian Basin ecosystem. Other cooperative studies could include identification of important subsistence harvest areas and surveys in nearshore areas and streams that could be affected by oil and gas development.

Members of the working group ranked study ideas from the group to identify priorities. Priority information needs and studies included:

- The impact of seismic surveys on fish. One suggestion was to compile historic information about locations of seismic surveys in the North Aleutian Basin and overlay fisheries data to evaluate if there were any detectable effects. However, it was noted that such a post-hoc study poses many statistical and scientific methodology problems and might not be feasible.

- Nearshore benthic fish distributions.

- Migration pathways for adult salmon.

- Late spring and early summer distributions of juvenile salmon, young-of-the-year pollock, and epipelagic fish species.

- Energy development conflicts with commercial fishing in the Sale 92 Area.

- Distribution and abundance of plankton (especially ichthyoplankton) within the North Aleutian Basin during May and September. 
Because the time available to the working group did not allow development of detailed study profiles, study profiles provided by some participants were considered and adopted by the group. In total, there were nine study profiles related to fish and fisheries topics in five general study categories (Table 4). Five studies were proposed to collect data on the distribution and abundance of important forage and fishery species within the North Aleutian Basin that could be affected by oil and gas development and to use currently available data to evaluate the degree to which oil and gas development activities within the Basin are likely to affect or conflict with fisheries (full study profiles are provided in Appendix C, Section C.3). The four remaining study profiles address key issues, but the group did not feel these four profiles deserved priority attention.

\section{TABLE 4. Fish and Fisheries Working Group Study Profiles}

\begin{tabular}{|c|c|}
\hline Study Category & Brief Description $^{\mathrm{a}}$ \\
\hline \multirow[t]{2}{*}{ Information } & $\begin{array}{l}\text { Develop a Web-based Bering Sea fish catalog using existing NMFS and other data to } \\
\text { evaluate potential for species of concern to occur in areas where oil and gas } \\
\text { development would occur. }\end{array}$ \\
\hline & $\begin{array}{l}\text { Compile historical information about seismic surveys and fishery information in } \\
\text { the North Aleutian Basin to evaluate whether there is evidence of potential effects. }\end{array}$ \\
\hline Nearshore surveys & $\begin{array}{l}\text { Conduct seasonal nearshore habitat assessments, evaluate juvenile fish abundance, } \\
\text { and identify potential spawning locations for species of concern on the Bering Sea } \\
\text { side of the Alaska Peninsula. }\end{array}$ \\
\hline Salmon & $\begin{array}{l}\text { Conduct late spring and early summer epipelagic surveys for juvenile salmon and } \\
\text { young of the year pollock. }\end{array}$ \\
\hline \multirow[t]{2}{*}{ Fisheries } & $\begin{array}{l}\text { Evaluate potential for fishing gear conflicts with energy development in Sale } 92 \\
\text { Area. }\end{array}$ \\
\hline & $\begin{array}{l}\text { Conduct local fishing community surveys and studies to predict potential impacts of oil } \\
\text { spills and development on commercial and recreational fisheries and related economies. }\end{array}$ \\
\hline \multirow[t]{3}{*}{ Other } & Conduct seasonal juvenile flat fish survey. \\
\hline & $\begin{array}{l}\text { Evaluate seasonal fish migration (especially cod and halibut) within the North Aleutian } \\
\text { Basin. }\end{array}$ \\
\hline & $\begin{array}{l}\text { Conduct pelagic studies of plankton (especially ichthyoplankton) during May and } \\
\text { September. }\end{array}$ \\
\hline
\end{tabular}

a Priority studies identified by the working group are presented in bold type. 


\subsection{BIRDS}

The Birds Working Group was assigned the task of developing study profiles that outlined high-priority research on seabirds and shorebirds needed to support environmental impact analyses of offshore oil and gas leasing in the North Aleutian Basin. John Krummel of Argonne facilitated working group discussions that included experts from USFWS, ADFG, Bureau of Land Management, MMS, and the University of Alaska-Fairbanks (see Appendix A, Table A-2). The working group included individuals with field and research experience in shorebird, sea duck, geese, and seabird ecology and management. In addition, over half of the group had direct field experience in the nearshore and sea areas of the Basin that contain important habitat for these bird populations (e.g., Izembek Lagoon National Wildlife Refuge, Nelson Lagoon). Local knowledge of habitat areas that could be within the range of influence of oil and gas leasing activities helped the working group better understand key research issues and set research priorities.

Three members of the working group provided overviews of the subject area at the beginning of the meeting. Kathy Kuletz summarized key issues related to seabirds and shorebirds, while Bill Larned and Chris Dau addressed sea ducks, geese, and important habitat issues in Bristol Bay and the Basin. The Basin contains world-class habitat that at certain times of the year supports a significant percentage of the world population of some species of seabirds and shorebirds, sea ducks, and geese. Extensive food resources in offshore, nearshore, and onshore habitats coupled with the northernmost icefree coastal areas in Alaska during the winter attract millions of resident and migratory birds.

\section{Working Group Process}

The facilitator outlined a proposed process that used worksheets to systematically outline issues and potential study needs. The working group had a number of questions related to MMS environmental impact analysis needs, schedule, and timing issues related to MMS oil and gas leasing activities. The MMS staff, who served as information resources on MMS needs and issues, provided summaries of the impact analysis process and how MMS used study profiles.

After initial questions and discussions, the group examined the first worksheet designed to help the group identify oil and gas development impacting factors, duration, and areas potentially affected. The group noted some new issues on the worksheet, but the members decided to forgo further review of the worksheet. The group then listed resources potentially atrisk to oil and gas development. Each member of the group was also asked to list their priority resources of concern. The outcome was an extensive list of resources for further consideration. The working group ended by focusing on three key issues: populations (species), food types (offshore, nearshore, and onshore), and key geographic areas important to bird population dynamics (breeding, feeding, and nesting). These categories also helped the group identify priority issues related to oil and gas leasing in the North Aleutian Basin.

The working group examined the remaining worksheets and decided that further use of the worksheets would be tabled; rather, the group would directly frame problem areas or study issues that could be developed into study profiles. Because the members of the group were 
familiar with important bird issues in the Basin and the MMS resource staff were able to highlight the impact analysis needs of oil and gas leasing, the first day produced a list of preliminary study issues.

The discussion then moved to a set of questions posed by the group to the MMS staff on what type of information had been helpful in the past when examining leasing issues and associated data needs for impact assessments. The MMS staff explained how data were obtained and how data gaps were addressed. A long discussion ensued on data requirements for ocean spills analysis and how linkages between spills modeling output and impact receptors were evaluated by MMS staff. After these discussions were completed, the facilitator went over the study profiles template with the group.

\section{Working Group Findings}

The group selected six priority studies based on group consensus, and divided into small groups, with each small group assigned to complete a draft study profile. The study profiles reflected key issues discussed in working group discussions:

- $\quad$ Lack of current and reliable population census data based on statistically valid sampling methods,

- Little information about winter population sizes or distributions,

- Oil spills as potential catastrophic events to bird populations (especially rare or threatened and endangered species),

- Bird populations that are spatially clustered during breeding or while at feeding areas (high exposure consequence to spills),

- Birds attracted to light sources during migration or feeding (infrastructure development for oil and gas activities), and

- Spatially clustered populations of birds that represent a significant percentage of the total world population (exposure to disturbance or spills).

The working group was especially concerned about impacting factors from oil and gas development that could perturb birds when populations congregate in relatively small areas (island nesting areas, tidal flats, ocean feeding areas). Ocean spills were viewed as potentially catastrophic events that could significantly reduce total world populations of certain species. Other impacting factors (light, construction, and operation disturbances) could also significantly threaten bird populations if these factors affected clustered populations.

The working group agreed that scientifically valid surveys were needed to determine the seasonal locations of key bird populations. These survey data would allow MMS to determine the risk to populations from ocean spills. Current information on the location of birds does not have the spatial or temporal resolution to reduce the high level of uncertainty for modeling the impacts of ocean spills on bird populations. While nesting and nearshore areas are periodically surveyed, some in the group noted that the data have not always been systematically collected and analyzed with valid statistical approaches. For ocean areas, virtually no systematic surveys have been conducted to determine where birds feed and congregate. 
Based on suggestions and discussions, the working group agreed to one final task at the end of the two day sessions: vote on ranking the six study profiles in terms of importance to the resource and MMS study needs for the leasing program. Each participant (not including the MMS staff and the facilitator) then anonymously voted for their top three study profiles. The results were tabulated and the profiles were then ranked from 1 (highest priority) to 6 (lowest priority).

The draft study profiles developed by the working group reflect the consensus professional opinion of the individuals who participated in the working group. The following study profiles were developed and are provided in Appendix C (Section C.4). They are listed in decreasing order of priority.

- Spatial and temporal distribution of Steller's eiders and other waterbirds,

- Spatial and temporal distributions of birds at sea,

- Seabird colony census and diet studies,

- Aerial remote sensing of distribution and abundance of eelgrass,

- Studies of the Izembek Lagoon and Port Moller Lagoon estuarine systems, and

- Spatial and temporal patterns of bird movements.

While process studies and linkages to other working group study priorities are noted, the birds working group strongly recommended that statistically valid seasonal (especially winter) population surveys should receive the highest MMS funding priority, especially for threatened and endangered species or to identify areas and times when a significantly large proportion of the world's population gathers in the North Aleutian Basin. The group also strongly advocated that bird surveys should not be conducted as “add-ons" to other research agendas (i.e., fish or marine mammals). In the past, bird observers have been placed on ships, but the sampling protocols have been dictated by other research priorities. Thus, many bird surveys are observations, rather than statistically valid samples.

\subsection{MARINE MAMMALS}

The Marine Mammals Working Group addressed each of the 21 marine mammals stocks that occur in the North Aleutian Basin but focused on threatened and endangered species and critical habitat. The working group was especially cognizant of the timing and scope of MMS leasing activities, because seismic studies could have potential impacts on many of the marine mammals in the Basin.

The working group session was facilitated by Ihor Hlohowskyj of Argonne. Participants in the working group included representatives from NMFS, USFWS, MMS, Shell Oil Co., ADFG, Aleut Corporation, and Aleutians East Borough (Appendix A, Table A-2). Representatives from other organizations also participated occasionally in the session as they moved among concurrent sessions of other working groups. 


\section{Working Group Process}

The working group session began with a brief introduction from the facilitator reviewing the overall objectives of the workshop and working groups. Overall, the working group identified oil and gas development-related activities that could affect marine mammals in the Basin, identified and prioritized marine mammal resources, identified nine studies for consideration of funding, and prioritized the implementation of these studies based on an expected timeline of oil and gas activities related to potential development in the Sale 92 Area.

The working group used the first worksheet to identify oil and gas development impacting factors, impact duration, and the area potentially affected. Discussion focused on seismic survey studies, because these surveys likely would be the first activities initiated in the Basin related to lease sales and development in the Sale 92 Area. There was general agreement among the participants that seismic surveys should be the initial focus of the working group. Additional discussion dealt with the spatial scale to be considered, namely, whether studies should focus only on the Sale 92 Area or include other portions of the Basin. The group decided to focus on the Sale 92 Area, while acknowledging that an accidental oil release could very likely move beyond the Sale 92 Area boundary and affect marine mammals and their habitats in other portions of the Basin.

The working group used the second worksheet to identify and prioritize resources potentially affected by oil and gas development, but revised the worksheet extensively. The working group felt it appropriate to identify marine mammal stocks as the potentially affected resources because that is how the species are protected and managed. The group developed five categories of importance for marine mammal stocks:

- $\quad$ Listing status (endangered, threatened, or depleted);

- $\quad$ Stock status (population is increasing, decreasing, stable, or unknown);

- Availability of current abundance estimate (yes, no, or poor);

- Percentage of the stock potentially affected (small, large, or all); and

- $\quad$ Subsistence use (yes or no).

Each of the 21 marine mammal stocks that occur in the Basin were then evaluated with regard to these categories and given an overall importance ranking of moderate or high. A stock was automatically given a high overall importance ranking when it was either threatened or endangered, the stock was declining, or the stock represented a subsistence resource. None of the stocks were considered to be of low importance. Of the 21 stocks evaluated, 11 were given a ranking of high, including:

- $\quad$ North Pacific right whale;

- $\quad$ Fin whale,;

- Humpback whale, western Pacific stock;

- Humpback whale, central Pacific stock;

- Beluga whale, Bristol Bay stock; 
- Steller sea lion, western U.S. stock;

- Northern fur seal, eastern North Pacific stock;

- Harbor seal, Bering Sea stock;

- Spotted seal, Alaska stock;

- Pacific walrus, Alaska stock; and

- Northern sea otter, southwest Alaska stock.

The working group then considered whether oil and gas exploration, development, and production in the Sale 92 Area has the potential to negatively affect the stocks using the following regulatory criteria:

- Adversely change a stock's population trajectory (MMPA);

- Adversely impact subsistence harvest (MMPA);

- Result in jeopardy of listed stocks (ESA);

- Adversely modify critical habitat (ESA); and

- Cause significant impacts (NEPA).

The working group felt that for each of the 11 high-importance stocks, oil and gas-related activities have the potential to adversely change a stock's population trajectory and cause significant impacts.

The working group next focused on identifying which of the following resource attributes was of most importance for each of the 11 high-importance stocks (using a modified third worksheet):

- Feeding;

- Resting (including haulouts, rafting areas, and nearshore areas);

- Reproduction (including mating, rearing, lactation, and other reproduction-related behaviors);

- Migration;

- Health; and

- Subsistence.

For the 11 high-importance marine mammal stocks, three resource attributes — feeding, reproduction, and health — were considered as potentially affected by oil and gas activities.

The working group then identified the important linkages between oil and gas activities and the 11 high-importance marine mammal stocks and their attributes. The current level of understanding of each stock's attributes and how those attributes could be affected by oil and gas activities was, in general, highest for the pinnipeds and the sea otter, and lowest for the cetaceans. Among all 11 stocks, the most commonly identified information need was related to 
location: namely, the distributions of the stocks and locations of feeding, migration, and reproduction areas within the Basin and especially in relationship to the Sale 92 Area.

Major discussions during the working group sessions centered around three topics: (1) the need for studies to support MMS decisions regarding the granting of permits for pre-lease-sale seismic surveys in the Sale 92 Area, (2) the spatial boundaries that should be considered by the proposed studies, and (3) the need to link resource concerns and proposed studies to the needs of the MMPA, ESA, and NEPA.

Very early on, a discussion was initiated regarding the prioritization of data needs. It was pointed out that while leasing and development of the Sale 92 Area is dependent on a number of issues, regardless of the outcome of these issues, MMS can receive a permit request for pre-lease seismic exploration. Indeed, seismic surveys would certainly be the first major activity in the area should issues be resolved to allow for development of the lease-sale area. Therefore, it was strongly argued and subsequently agreed upon by the working group, that studies addressing the impacts of seismic surveys should receive highest priority for funding.

Issues related to the spatial scale that should be considered by the study profiles were discussed primarily with regard to three potential oil and gas-related activities: seismic surveys, accidental oil spills, and tankering on the Gulf of Alaska coast. Both seismic surveys and oil spills have the potential to affect marine mammal stocks outside the sale area proper. Seismic surveys have the potential to affect animals throughout the Basin, regardless of survey location, whereas permit applications for seismic surveys may be requested for any portion of the Basin. Accidental oil spills were also acknowledged to have the potential for affecting marine mammal habitats outside the Sale 92 Area, especially in the event of a catastrophic accidental release.

Finally, the known or presumed distributions of marine mammal stocks in the Basin is not restricted to the sale area, but includes other portions if not all of the Basin as well as areas beyond. The importance of Unimak Pass as a major corridor used by all listed cetaceans traveling between the Basin and the Gulf of Alaska was brought up on several occasions. Oil and gas production in the Basin would also require the construction and operation of storage and transportation facilities on the southern coast of the Alaska Peninsula, as well as tankering in the Gulf of Alaska of products from those facilities.

The third major area of discussion was related to the need to show what kinds of questions would be asked by the three major environmental regulations: MMPA, ESA, and NEPA. In other words, what are the questions that would be asked under each of these statutes when determining whether oil and gas development in the Basin could adversely affect marine mammal stocks in the Basin? Examination of these questions would help direct and prioritize study needs.

\section{Work Group Findings}

Nine study profiles were developed to address marine mammal issues in the Sale 92 Area and the North Aleutian Basin as a whole (Table 5 and Appendix C, Section C.5). These studies would provide important baseline information on the distribution, movements, and migration 
patterns of marine mammal stocks within and through the Basin and their occurrence within the Sale 92 Area. The nine study profiles focus on nine of the 11 marine mammal stocks identified by the working group as having the highest importance for research and study profile development. Two stocks, the beluga whale Bristol Bay stock and the northern fur seal eastern North Pacific stock, are not directly addressed by the study profiles. No study profile was developed for the beluga whale because it was felt that the Bristol Bay stock would only be affected in the event of an accidental oil spill. Thus, study profiles for this stock could be developed at a later time. No study profiles were developed for the northern fur seal because satellite-tagging studies of this species are currently underway.

These nine study profiles were prioritized with regard to the anticipated sequence of activities that would occur with oil and gas development of the Sale 92 Area and to MMS needs for preparing defensible NEPA analyses. These activities and needs, in chronological order, are:

1. Pre-lease seismic exploration,

2. Lease-sale EIS-related analyses,

3. Project development, and

4. Oil and gas production.

Three study profiles were identified for immediate startup (by FY 2007-2008), five studies for startup by FY 2008-2009 to support lease-sale- and EIS-related analyses, and one study for startup by the beginning of oil and gas development within the sale area (Table 5).

TABLE 5. Study Profiles Developed by the Marine Mammals Working Group

\begin{tabular}{|c|c|c|c|}
\hline Study Profile & Start (FY) & $\begin{array}{l}\text { Duration } \\
\text { (year) }\end{array}$ & $\begin{array}{l}\text { Total Cost } \\
(\$)\end{array}$ \\
\hline $\begin{array}{l}\text { Distribution, abundance, and habitat use of North } \\
\text { Pacific right whales }\end{array}$ & $2007-2008$ & 4 & $3,190,000$ \\
\hline $\begin{array}{l}\text { Seasonal acoustic monitoring of right whales and } \\
\text { other endangered cetaceans }\end{array}$ & $2007-2008$ & 4 & 720,000 \\
\hline $\begin{array}{l}\text { Abundance, distribution and seasonal movements } \\
\text { of humpback, fin, and other cetaceans }\end{array}$ & $2007-2008$ & 4 & 845,000 \\
\hline Health assessment of stranding marine mammals & 2008-2009 & 4 & 875,000 \\
\hline Steller sea lion seasonal distribution and diet & 2008-2009 & 3 & 450,000 \\
\hline Steller sea lion seasonal habitat use & 2008 & 3 & 940,000 \\
\hline Harbor seal and spotted seal seasonal distribution & 2008 & 4 & $1,355,000$ \\
\hline $\begin{array}{l}\text { Seasonal distribution and abundance of Pacific } \\
\text { walrus }\end{array}$ & 2008 & 3 & 660,000 \\
\hline \multirow[t]{2}{*}{$\begin{array}{l}\text { Seasonal distribution and abundance of northern } \\
\text { sea otter }\end{array}$} & 2009 & 3 & $1,270,000$ \\
\hline & & Total & $10,305,000$ \\
\hline
\end{tabular}




\section{CONCLUSIONS AND RECOMMENDATIONS}

Plenary speakers and meeting participants emphasized the critical importance of resources in the North Aleutian Basin, including human subsistence resources, commercial fisheries, and internationally important bird and marine mammal populations and habitats. Despite the importance of these resources, a number of topical areas were identified where basic information was lacking or incomplete. Critical information needs included:

- High-resolution data to improve existing models of circulation and physical oceanography,

- Characterization of existing resources and their status in the Basin;

- Distributions of resources in the Basin; life history and seasonal patterns of use;

- Population trends of important species; and

- $\quad$ Effects of seismic activities on ecological resources.

In general, meeting participants found that current information is insufficient to address oil and gas leasing issues. The study profiles that were developed at the meeting represent the highest-priority studies identified by the working groups.

Some of these information needs can be addressed by systematically evaluating existing data collected by various agencies with an eye toward characterizing distribution, status, and trends and looking for patterns of change that could indicate effects of environmental perturbations over the last few decades. These types of analyses could be particularly important for assessing the effects of leasing, exploration, development, and production activities related to oil and gas development. Study profiles were developed in these areas, and, if funded, could represent an important first step for the program. Such studies include:

- Compile historical information about seismic surveys and fishery information in the North Aleutian Basin;

- Evaluate potential for space-use conflicts between fishery activities and oil and gas development activities within the Sale 92 Area; and

- Compile North Aleutian Basin socioeconomics data.

Some data needs are critically important because there is little Basin-specific information on the topic, the resource is considered of vital importance, and the information is needed as early as possible in the lease-exploration-development-production timeline. On the basis of information gathered at the meeting, Argonne staff identified two topics that fit these criteria: (1) studies of the endangered North Pacific right whale and (2) studies of subsistence patterns. Three study profiles are related to these topics:

- Distribution, abundance, and habitat use of North Pacific right whales,

- Seasonal acoustic monitoring of right whales and other endangered cetaceans, and

- $\quad$ North Aleutian Basin subsistence. 
The North Pacific right whale is an endangered species with critical habitat in the Basin, specifically in the Sale 92 Area. Data are needed early because the species is potentially affected by seismic surveys that could occur within the next few years. Subsistence resources are vitally important to residents of the areas and could be affected by all aspects of oil and gas development including leasing and exploration. These study profiles are of greatest importance in the earliest phases of the North Aleutian Basin leasing program.

Assessments of the effects of oil and gas development activities in the North Aleutian Basin could greatly benefit from development of a high-resolution model of the Basin that represented important physical processes. Such a model would be useful for predicting the fate and effects of oil spills or other contaminant releases and could also be linked to information collected on other resources in the Basin to better understand the underlying bases of distributions, seasonal patterns of use, population trends, and changes in status. Although a fully developed high-resolution model would be useful now, it will be most critical several years from now for use in the assessments of development and production plans. Study profiles related to modeling physical processes include:

- Implementation of a meteorological buoy;

- Mesoscale meteorological modeling;

- Physical oceanography field program; and

- Modeling of circulation.

Other study profiles that were developed at the meeting will be useful for developing a monitoring program of the effects of oil and gas development in the North Aleutian Basin. To be most effective, these studies should start sometime prior to the initiation of oil and gas activities in order to establish baseline data.

Studies and the environmental assessment program they support will be greatly strengthened by strong communication among principal investigators and MMS staff and integration of studies to the extent possible. Studies should focus on hypothesis testing and employ robust statistical design using appropriate sample sizes and data quality objectives identified before the studies are implemented. Standardization of common data needed by several programs, avoidance of duplication of effort, and development of a Web-based data system using standard metadata procedures would maximize the usability of results and make the results available to a wider group of potential users. 


\section{REFERENCES}

Maslowski, W. 2007. "Modeling Recent Climate Variability in the Arctic Ocean," at The Naval Postgraduate School Modeling Effort (Web site). Naval Postgraduate School, Monterey, Calif. Available at: www.oc.nps.navy.mil/NAME/name.html. Accessed March 22, 2007.

Maslowski, W., D.C. Marble, W. Walczowski, and A.J. Semtner. 2001. "On Large Scale Shifts in the Arctic Ocean and Sea Ice Conditions during 1979-1998.” Annals of Glaciology 33:545-550.

Maslowski, W., B. Newton, P. Schlosser, A. Semter, and D. Martinson. 2000. "Modeling Recent Climate Variability in the Arctic Ocean.” Geophysical Research Letters 27(22):3743-3746.

Minerals Management Service. 2006. Outer Continental Shelf Oil and Gas Leasing Program: 2007-2012 - Draft Environmental Impact Statement. OCS EIS/EA MMS 2006-004.

U.S. Department of the Interior, Minerals Management Service, Herndon, Va.

Sherwood, K.W., J. Larson, C.D. Comer, J.D. Craig, and C. Reitmeier. 2006. "North Aleutian Basin Outer Continental Shelf Planning Area-Assessment of Undiscovered TechnicallyRecoverable Oil and Gas As of 2006.” U.S. Department of the Interior, Minerals Management Service, Alaska OCS Region, Anchorage. Available at: http://www.mms.gov/alaska/re/reports/ NAB06/North\%20Aleutian\%20Basin\%20Assessment\%20Report.pdf. Accessed March 19, 2007. 


\section{APPENDIX A}

REGISTRANTS AND WORKING GROUP MEMBERS OF THE NORTH ALEUTIAN BASIN INFORMATION STATUS AND RESEARCH PLANNING MEETING 
TABLE A-1. Registrants of the North Aleutian Basin Information Status and Research Planning Meeting

\begin{tabular}{|c|c|}
\hline Name & Affiliation \\
\hline Tom Ahlfeld & Minerals Management Service \\
\hline Randy Alvarez & Bristol Bay Native Association \\
\hline Jeffry Anderson & U.S. Fish and Wildlife Service \\
\hline Scott Anderson & Lake and Peninsula Borough \\
\hline Tina Anderson & Aleutians East Borough \\
\hline Robyn Angliss & National Marine Fisheries Service \\
\hline Eric Barnhill & Bering Sea Fishermen’s Association \\
\hline Carrie Beck & Alaska Department of Fish and Game \\
\hline John Bengtson & National Marine Fisheries Service \\
\hline Shelby Booth & Bristol Bay Borough \\
\hline Brad Boschetto & Shell Oil Co. \\
\hline Peter Boveng & National Marine Fisheries Service \\
\hline Sharon Boyette & Aleutians East Borough \\
\hline Judy Brady & Alaska Oil and Gas Association \\
\hline Heather Brandon & Alaska Department of Fish and Game \\
\hline Reid Brewer & University of Alaska Sea Grant \\
\hline James Browning & Alaska Fisheries Development Foundation \\
\hline Casey Buechler & Minerals Management Service \\
\hline Colleen Burgh & U.S. Environmental Protection Agency \\
\hline Doug Burn & U.S. Fish and Wildlife Service \\
\hline Mike Burwell & Minerals Management Service \\
\hline Lynn Carlson & Lake and Peninsula Borough \\
\hline Molly Chythlook & Bristol Bay Native Association \\
\hline Phil Clapham & National Marine Fisheries Service \\
\hline Cleve Cowles & Minerals Management Service \\
\hline Wayne Crayton & Minerals Management Service \\
\hline Jennifer Curtis & U.S. Environmental Protection Agency \\
\hline Doug Dasher & Alaska Department of Environmental Conservation \\
\hline Chris Dau & U.S. Fish and Wildlife Service \\
\hline Brian Davis & Private consultant \\
\hline Angela Doroff & U.S. Fish and Wildlife Service \\
\hline Matthew Eagleton & National Marine Fisheries Service \\
\hline Lisa Eisner & National Marine Fisheries Service \\
\hline
\end{tabular}


Table A-1 (Cont.)

\begin{tabular}{|c|c|}
\hline Name & Affiliation \\
\hline Diana Evans & North Pacific Fisheries Management Council \\
\hline Julian Fischer & U.S. Fish and Wildlife Service \\
\hline Cathy Foy & National Marine Fisheries Service \\
\hline Joel Garlich-Miller & U.S. Fish and Wildlife Service \\
\hline Duane Gill & Minerals Management Service-Scientific Committee \\
\hline Karen Gillis & Bering Sea Fishermen’s Association \\
\hline Ed Glazier & Impact Assessment Inc. \\
\hline Jeff Gleason & Minerals Management Service \\
\hline Larry Gorenflo & Argonne National Laboratory \\
\hline Stephen Grabacki & Graystar Pacific Seafood \\
\hline Glenn Gray & Aleutians East Borough \\
\hline Paul Grundholt & Aleutians East Borough \\
\hline Justine Gundersen & Aleutians East Borough \\
\hline Kelly Harrell & Friends of Bristol Bay \\
\hline John Hayse & Argonne National Laboratory \\
\hline Kate Hedstrom & University of Alaska \\
\hline Adelheid Herrmann & Native American Fish and Wildlife Society \\
\hline Ihor Hlohowskyj & Argonne National Laboratory \\
\hline Warren Horowitz & Minerals Management Service \\
\hline Steve Howell & Cook Inlet Regional Citizens Advisory Council \\
\hline Gary Hufford & National Weather Service \\
\hline Yulia Ivashchenko & Sea Star Scientific \\
\hline Allison Iversen & Alaska Department of Natural Resources \\
\hline Gary Johnson & Aleutians East Borough \\
\hline Walter Johnson & Minerals Management Service \\
\hline James Kendall & Minerals Management Service \\
\hline Gunnar Knapp & University of Alaska \\
\hline Brenda Konar & University of Alaska \\
\hline Yvonne Kopy & Bristol Bay Borough \\
\hline John Krummel & Argonne National Laboratory \\
\hline Kathy Kuletz & U.S. Fish and Wildlife Service \\
\hline Liz Labunski & U.S. Fish and Wildlife Service \\
\hline Kirk LaGory & Argonne National Laboratory \\
\hline Ron Lai & Minerals Management Service \\
\hline
\end{tabular}


Table A-1 (Cont.)

\begin{tabular}{|c|c|}
\hline Name & Affiliation \\
\hline Bill Larned & U.S. Fish and Wildlife Service \\
\hline Terri Lomax & Alaska Department of Environmental Conservation \\
\hline Wieslaw Maslowski & Naval Postgraduate School \\
\hline Molly McCammon & Alaska Ocean Observing System \\
\hline Peter McRoy & University of Alaska \\
\hline Rob McWhorter & Argonne National Laboratory \\
\hline Doug Mecum & National Marine Fisheries Service \\
\hline Phil Mundy & National Marine Fisheries Service \\
\hline Mary Lynn Nation & U.S. Fish and Wildlife Service \\
\hline Tom Newbury & Minerals Management Service \\
\hline Richard Newman & Minerals Management Service \\
\hline Debbie Nigro & Bureau of Land Management \\
\hline David Osterback & Aleutian Pribilof Islands Association \\
\hline Nikos Pastros & Confederated Salish-Kootenai Tribes of Flathead Nation \\
\hline Robert Pawlowski & Alaska Fisheries Development Foundation \\
\hline Mike Petrula & Alaska Department of Fish and Game \\
\hline Karen Pletnikoff & Aleutian Pribilof Islands Association \\
\hline Richard Prentki & Minerals Management Service \\
\hline Ann Rappoport & U.S. Fish and Wildlife Service \\
\hline Lorrie Rea & Alaska Department of Fish and Game \\
\hline Kate Reedy-Maschner & Aleutians East Borough \\
\hline Dan Rosenberg & Alaska Department of Fish and Game \\
\hline Lisa Rotterman & Minerals Management Service \\
\hline Susan Savage & U.S. Fish and Wildlife Service \\
\hline Will Schroeder & Minerals Management Service-Scientific Committee \\
\hline Whit Sheard & Pacific Environment \\
\hline Mike Sigler & National Marine Fisheries Service \\
\hline Brad Smith & National Marine Fisheries Service \\
\hline Caryn Smith & Minerals Management Service \\
\hline Tiel Smith & Bristol Bay Native Corporation \\
\hline Ron Stanek & Alaska Department of Fish and Game \\
\hline Paul Stang & Minerals Management Service \\
\hline Chris Stark & Bering Sea Fishermen’s Association \\
\hline Rick Steiner & University of Alaska Anchorage \\
\hline
\end{tabular}


Table A-1 (Cont.)

\begin{tabular}{ll}
\hline \multicolumn{1}{c}{ Name } & \multicolumn{1}{c}{ Affiliation } \\
\hline Charla Sterne & U.S. Fish and Wildlife Service \\
Elisabeth Stull & Argonne National Laboratory \\
John Trent & U.S. Fish and Wildlife Service \\
Della Trumble & Aleutians East Borough \\
Ian Voparil & Shell Oil Co. \\
Barbara Wallace & Minerals Management Service \\
Sharon Warren & U.S. Department of the Interior \\
Kate Wedemeyer & Minerals Management Service \\
Fred West & Alaska Department of Fish and Game \\
Dee Williams & Minerals Management Service \\
Margaret Williams & World Wildlife Fund \\
Mike Williams & National Marine Fisheries Service \\
\hline
\end{tabular}


TABLE A-2. Members of North Aleutian Basin Working Groups

\begin{tabular}{|c|c|}
\hline Name & Organization \\
\hline \multicolumn{2}{|c|}{ Oceanography, Ecosystems, and Fate and Effects Working Group } \\
\hline Anderson, Tina & Aleutians East Borough \\
\hline Burgh, Colleen & U.S. Environmental Protection Agency \\
\hline Eisner, Lisa & National Marine Fisheries Service \\
\hline Hartung, Daniel & Minerals Management Service \\
\hline Hedstrom, Kate & University of Alaska, Fairbanks \\
\hline Horowitz, Warren & Minerals Management Service \\
\hline Hufford, Gary & National Weather Service \\
\hline Johnson, Walter & Minerals Management Service \\
\hline Lai, Ron & Minerals Management Service \\
\hline Maslowski, Wieslaw & Naval Postgraduate School \\
\hline McRoy, Peter & University of Alaska \\
\hline Mundy, Phil & National Marine Fisheries Service \\
\hline Newman, Richard & Minerals Management Service \\
\hline Prentki, Dick & Minerals Management Service \\
\hline Schroeder, Will & Minerals Management Service-Scientific Comm. \\
\hline Smith, Caryn & Minerals Management Service \\
\hline Sterne, Carla & U.S. Fish and Wildlife Service \\
\hline Stull, Elisabeth & Argonne National Laboratory \\
\hline \multicolumn{2}{|c|}{ Socioeconomics and Subsistence Working Group } \\
\hline Alvarez, Randy & Bristol Bay Native Association \\
\hline Brewer, Reid & University of Alaska Sea Grant \\
\hline Burwell, Mike & Minerals Management Service \\
\hline Cowles, Cleve & Minerals Management Service \\
\hline Davis, Brian & Consultant \\
\hline Glazier, Ed & Impact Assessment Inc. \\
\hline Gorenflo, Larry & Argonne National Laboratory \\
\hline Kopy, Yvonne & Bristol Bay Borough \\
\hline Livingston, Caleb & Not stated \\
\hline Logusak, Frank & Aleutian Pribilof Islands Association \\
\hline Osterback, David O. & Aleutian Pribilof Islands Association \\
\hline Pletnikoff, Karen & Aleutian Pribilof Islands Association \\
\hline Reedy-Maschner, Kate & Aleutians East Borough \\
\hline
\end{tabular}




\section{Table A-2 (Cont.)}

\begin{tabular}{|c|c|}
\hline Name & Organization \\
\hline \multicolumn{2}{|c|}{ Socioeconomics and Subsistence Working Group (Cont.) } \\
\hline Sivarng-Livingston, Sharon & Not stated \\
\hline Stanek, Ron & Alaska Department of Fish and Game \\
\hline Trent, John & U.S. Fish and Wildlife Service \\
\hline Trumble, Della & Aleutians East Borough \\
\hline Wallace, Barbara & Minerals Management Service \\
\hline Way, Ruthie & Minerals Management Service \\
\hline Williams, Dee & Minerals Management Service \\
\hline \multicolumn{2}{|c|}{ Fish and Fisheries Working Group } \\
\hline Ahlfeld, Tom & Minerals Management Service \\
\hline Anderson, Jeffry & U.S. Fish and Wildlife Service \\
\hline Booth, Shelby & Bristol Bay Borough \\
\hline Buechler, Casey & Minerals Management Service \\
\hline Eagleton, Matthew & National Marine Fisheries Service \\
\hline Evans, Diana & North Pacific Fisheries Management Council \\
\hline Grundholt, Paul & Aleutians East Borough \\
\hline Gundersen, Justine & Aleutians East Borough \\
\hline Hayse, John & Argonne National Laboratory \\
\hline Herrmann, Adelheid & Native American Fish and Wildlife Society \\
\hline Jacobsen, Dick & Aleutians East Borough \\
\hline Johnson, Gary & Aleutians East Borough \\
\hline Knapp, Gunnar & University of Alaska \\
\hline Konar, Brenda & University of Alaska \\
\hline Olsen, Myra & Lake and Peninsula Borough \\
\hline Schrof, Steve & Alaska Department of Fish and Game \\
\hline Sigler, Mike & National Marine Fisheries Service \\
\hline Stark, Chris & Bering Sea Fishermen’s Association \\
\hline Voparil, Ian & Shell Oil Co. \\
\hline Wedemeyer, Kate & Minerals Management Service \\
\hline \multicolumn{2}{|l|}{ Birds Working Group } \\
\hline Castellini, Mike & University of Alaska \\
\hline Dau, Chris & U.S. Fish and Wildlife Service \\
\hline Fischer, Julian & U.S. Fish and Wildlife Service \\
\hline
\end{tabular}




\section{Table A-2 (Cont.)}

\begin{tabular}{ll}
\hline \multicolumn{1}{c}{ Name } & \multicolumn{1}{c}{ Organization } \\
\hline Birds (Cont.) & \\
Gleason, Jeffery & Mineral Management Service \\
Kendall, Jim & Mineral Management Service \\
Krummel, John & Argonne National Laboratory \\
Kuletz, Kathy & U.S. Fish and Wildlife Service \\
Larned, Bill & U.S. Fish and Wildlife Service \\
Nigro, Debbie & Bureau of Land Management \\
Rosenberg, Dan & Alaska Department of Fish and Game \\
Savage, Susan & U.S. Fish and Wildlife Service \\
Schroeder, Mark & Mineral Management Service \\
Sterne, Charla & U.S. Fish and Wildlife Service \\
Marine Mammals Working Group \\
Angliss, Robyn & National Marine Fisheries Service \\
Beck Eischens, Carrie & Alaska Department of Fish and Game \\
Bengston, John & National Marine Fisheries Service \\
Boschetto, Brad & Shell Oil Co. \\
Boveng, Peter & National Marine Fisheries Service \\
Burn, Douglas & U.S. Fish and Wildlife Service \\
Clapham, Philip & National Marine Fisheries Service \\
Garlich-Miller, Joel & U.S. Fish and Wildlife Service \\
Gundersen, Butch & Aleutians East Borough \\
Hlohowskyj, Ihor & Argonne National Laboratory \\
Ivanshchenko, Yulia & Seastar Scientific Consulting \\
Kendall, Jim & Minerals Management Service \\
Mack, Stanley & Aleut Corporation \\
Monnett, Charles & Minerals Management Service \\
Rotterman, Lisa & Minerals Management Service \\
Smith, Brad & National Marine Fisheries Service \\
\hline &
\end{tabular}




\section{APPENDIX B \\ SPEAKER BIOGRAPHIES AND PRESENTATIONS GIVEN AT THE NORTH ALEUTIAN BASIN INFORMATION STATUS AND RESEARCH PLANNING MEETING}




\section{SPEAKER BIOGRAPHIES}

John Bengtson is Director of the National Marine Mammal Laboratory, Alaska Fisheries Science Center, National Marine Fisheries Service/NOAA, in Seattle. John is trained as a wildlife ecologist, having earned an M.S. (reproductive biology of crabeater seals) and Ph.D. (ecology and behavior of manatees) from the University of Minnesota. He started his graduate studies at the University of Alaska-Fairbanks, in 1975, studying Arctic fox movements at Prudhoe Bay. For the past 30 years, he has studied wildlife in Alaska (ringed, bearded, spotted, ribbon, and harbor seals; northern fur seals; sea otters; Arctic fox), Antarctica (crabeater, leopard, Weddell, and Ross seals; Antarctic fur seals; chinstrap, gentoo, and macaroni penguins), and Florida and Belize (American kestrels, manatees). An underlying motivation for much of his research has been to investigate the natural variation and ecological patterns in the interactions among marine mammals, birds, and their environment. Trying to understand how climate change is affecting and altering high latitude ecosystems has become an increasingly important part of this research in recent years.

Dr. Bengtson has been active in international treaty and research organizations concerned with Antarctic and Arctic wildlife research and conservation. He was Convener of the Group of Specialists on Seals for the Scientific Committee on Antarctic Research (SCAR), and was Chairman of SCAR's Antarctic Pack Ice Seals Program, a research initiative involving scientists from nearly 20 nations. He was a founding member and Convener of the international Commission for the Conservation of Antarctic Marine Living Resources (CCAMLR) Ecosystem Monitoring Program, and he is currently Co-Chair of the U.S./Russia Marine Mammal Working Group, an organization that has promoted collaboration and coordination of research between these two countries since the early 1970s. He has served on many U.S. governmental delegations to meetings of the Arctic Council's Conservation of Arctic Flora and Fauna Working Group, U.S./Russia Environmental Agreement, CCAMLR, Antarctic Treaty, and Antarctic Seals Convention.

During the past decade, John has been a leader in implementing new initiatives under the U.S. Marine Mammal Protection Act, which in 1994 was amended to provide for cooperative agreements between the National Marine Fisheries Service and Alaska Native organizations to co-manage marine mammal populations used for subsistence purposes. He participates in several committees and forums where Alaska Natives and federal biologists work together to address issues of mutual concern pertaining to conservation, research, education, and resource management of marine mammals.

Phillip Clapham oversees large whale research at the National Marine Mammal Laboratory in Seattle, where his work focuses on population biology, behavioral ecology, and conservation management. He has more than 25 years of experience with cetaceans, and at one time or another has worked with most species of whales in various places worldwide. Prior to his current position, he worked at the Northeast Fisheries Science Center in Woods Hole, Massachusetts. He remains associated with the Smithsonian Institution (National Museum of Natural History) in Washington, D.C., and for many years directed a long-term study of individually identified humpback whales at the Center for Coastal Studies in Massachusetts. He holds a Ph.D. in zoology from the University of Aberdeen (Scotland), and has advised several governments and 
other bodies on whale research and conservation. Dr. Clapham has served on the Board of Governors of the Society for Marine Mammalogy, and is a member of the U.S. delegation to the International Whaling Commission's Scientific Committee. He edits for three scientific journals, and has himself published four books and about 100 peer-reviewed papers on whales and other cetaceans.

Cleve Cowles, Ph.D., is the Chief, Environmental Studies Section (ESS), Alaska Outer Continental Shelf (OCS) Region, Minerals Management Service (MMS). His responsibilities include leadership of MMS Alaska Environmental Studies Program. Cleve has been with the BLM/MMS Alaska OCS Region since 1979, serving as Wildlife Biologist (Endangered Species), Chief of the Environmental Studies Unit (1983-1994), Acting Chief of the Social and Economic Studies Unit (1992-1994), and ESS Chief since 1995. Collateral responsibilities have included serving as the MMS Technical Representative to the OCSEAP program (1983-1992), to the MMS/UAF Coastal Marine Institute (1994-present), and recently to the North Slope Science Initiative and to the Pacific Northwest Cooperative Ecosystem Studies Unit. He received his B.S. in Wildlife Science from the University of Maine (1969) and M.S. (1974) and Ph.D. (1979) in Fisheries and Wildlife Sciences at Virginia Polytechnic Institute and State University. Design and analysis of management decision systems, environmental research monitoring, cooperative project development, and information applications to decision making continue as his career interests. He has authored or coauthored articles in Journal of Environmental Management, Arctic, Journal of Mammalogy, Journal of Wildlife Management, and elsewhere.

Christian P. Dau is a wildlife biologist with the Migratory Bird Management Division of the U.S. Fish and Wildlife Service in Anchorage, Alaska. He has been with the Service for over 30 years, primarily involved with tundra waterbird studies. Studies have centered on ecology of geese and sea ducks in western and southwestern Alaska. He spent 9 years on the YukonKuskokwim Delta and 16 years on the southern Alaska Peninsula serving as biologist for the Yukon delta and Izembek National Wildlife refuges. Chris has bachelor's degree in zoology from Fresno State College and a master's degree in wildlife management from the University of Alaska-Fairbanks.

Brian Davis is a Cultural Anthropologist living in Anchorage. He has a B.A. in Anthropology from the University of Notre Dame, and an M.A. in Anthropology from the University of Alaska Fairbanks, with a focus on cultural and historic aspects of subsistence resource use. From 1999 to 2006, Davis worked for the Alaska Department of Fish and Game, Division of Subsistence, as a researcher, project lead, and Program Coordinator. Since 1993, Davis has worked on archaeological and natural resource projects with Alaska Native organizations in the Aleutians, Kodiak, Southeast Alaska, and the Bristol Bay region.

Angela Doroff is a wildlife biologist with the U.S. Fish and Wildlife Service in Anchorage, Alaska. She began her work on sea otters in 1985 and has since worked in Alaska, California, and the Commander Islands, Russia. She has worked on damage assessment studies for four years following the 1989 Exxon Valdez oil spill in Prince William Sound. Since then she has been conducting sea otter population assessment studies, development of conservation plans, international coordination, sea otter health and condition studies, and outreach activities. She is the species contact for the International Union of the Conservation of Nature's otter working 
group. Ms. Doroff has an M.S. degree in wildlife ecology from the University of Wisconsin, Madison, and a B.S. degree in biology from the University of Minnesota, Minneapolis.

Diana Evans of the North Pacific Fisheries Management Council graduated from the University of California, Berkeley (B.A. Geography and Linguistics), and received her M.S. in Geography from King's College London, University of London, in 1998. She has worked as National Environmental Policy Act specialist and fishery analyst for the North Pacific Fishery Management Council since 2002, and is currently the staff representative to the Council's ecosystem committee. She previously worked as a consultant on fishery environmental impact statements for National Marine Fisheries Service in Alaska and Hawaii.

Edward W. Glazier has been involved in various forms of social science research along the coastal zone of the U.S. since 1978. He earned a B.A. in anthropology from the University of North Carolina at Wilmington with a senior paper on dietary patterns among Algonkian tribes living along the Mid-Atlantic coast during the 11th century. His master's thesis in sociology at East Carolina University examines socio-cultural dimensions of the Exxon Valdez oil spill. His doctoral dissertation in sociology at the University of Hawaii at Manoa describes socioeconomic aspects of small boat fishing in the Main Hawaiian Islands, and explains why Native Hawaiian fishermen persist despite the various social forces and factors that constrain them at the beginning of the 21st century (the setting and situation is described in Hawaiian Fishermen, 2007, Wadsworth-Thomson Publishers). Dr. Glazier's tenure at Impact Assessment Inc., began during its 1989-1990 study of the Exxon Valdez oil spill. His work on OCS Study MMS 2004-038 is summarized in "Toward Mitigating Problems at the Fisheries-Oil Development Interface: The Case of the Salmon Drift Gillnet Fishery in Cook Inlet, Alaska,” recently published in Human Organization, Volume 65, Number 3 (Fall 2006). Edward is Research Director for the Pacific Islands Office of Impact Assessment, Inc., where he is engaged in various maritime social science research projects in Alaska, Hawaii, and the Western Pacific.

Larry Gorenflo holds advanced degrees in anthropology (M.A., University of Michigan) and geography (Ph.D., University of California, Santa Barbara). His interest focuses on the relationship between humans and their natural environment, emphasizing how people adapt to their natural and cultural surroundings. Through exploring patterns of human adaptation with a range of analytical methods, including geographic information system technology and statistical analysis, Dr. Gorenflo’s research emphasizes identifying spatial patterns of human behavior and, often, the impacts of this behavior. He has conducted research and published on human adaptation in Latin America and the Caribbean, Oceania, Africa, and the United States (including Alaska), as well as at a global scale.

John Hayse received his Ph.D. in Zoology from Miami University in 1991. He has 20 years of experience in marine and freshwater ecology. Since 1991 he has served as an ecologist in Argonne National Laboratory’s Environmental Science Division. Recent and ongoing project activities include evaluations of impacts to aquatic ecosystems from hydropower operations, training environmental project managers to prepare ecological risk assessments that conform to U.S. EPA guidance, and assessment of the ecological consequences of renewing the TransAlaska Pipeline System right-of-way and of the MMS's proposed oil and gas leasing program for the outer continental shelf. Current research includes development of individual-based models to 
evaluate effects of hydropower operations on survival and growth of trout and endangered fish populations.

Ihor Hlohowskyj received his Ph.D. in Zoology in 1986 from Miami University. He has over 25 years experience in aquatic and terrestrial ecology, ecological risk assessment, and environmental impact assessment. He has worked on a variety of projects throughout North America and abroad. His work has included the identification and training of methods for assessing potential climate change impacts on African fisheries, ecological risk assessments at military training facilities, risk assessment training for the Department of Defense and U.S. Department of Energy, and ecological evaluations of wind energy development on federal lands in the western U.S. His current activities include development of biomonitoring guidelines for the U.S. Navy, assessing the impacts of energy corridor designation on federal lands in the western U.S., and assessment of ecological impacts from oil, natural gas, and alternate energy leasing and development on the Outer Continental Shelf. Dr. Hlohowskyj is the author of over 100 journal articles, book chapters, reports, and conference publications.

Gunnar Knapp is a Professor of Economics at the University of Alaska-Anchorage Institute of Social and Economic Research, where he has worked since receiving his Ph.D. in Economics from Yale University in 1981. Dr. Knapp has written numerous research reports on the economy of Alaska and the management of and markets for Alaska natural resources. For the past 15 years he has been actively involved in research on markets for and management of Alaska fisheries, including salmon, pollock, crab, and halibut.

John Krummel received his Ph.D. in Ecology from Cornell University in 1978. His early work focused on integrated pest management and agro-ecosystems. Upon joining the staff of Oak Ridge National Laboratory in Tennessee, Dr. Krummel joined forces with several other staff scientists to initiate a landscape ecology program that developed many of the early concepts and tools of this emerging area of study. Dr. Krummel joined Argonne National Laboratory in Illinois in 1986 and continued work in spatial analysis and ecology. He helped develop a geographic information systems laboratory that became an integral part of a large program in environmental assessment. A key part of Dr. Krummel's current work is assisting federal land management agencies in resource planning, such as resolving energy-environment issues in Alaska.

Kathy Kuletz has lived in Alaska for 32 years, and has spent over 20 years studying and surveying marine birds. She has served as principal investigator for studies involving seabird diet, productivity, habitat use, and population trends. Most of this work has been with the U.S. Fish and Wildlife Service out of the Anchorage office of Migratory Bird Management. She received her Ph.D. from the University of Victoria, B.C., her master's from the University of California, Irvine, and her B.S. from California Polytechnic State University at San Luis Obispo. Dr. Kuletz is a member of the Groundfish Fisheries Ecosystem Plan Team and the Short-tailed Albatross Recovery Team. She is currently principal investigator for the North Pacific Pelagic Seabird Observer Program. Her other work experience in Alaska has been as a commercial salmon fisher, and her husband, son, and brother still fish in Bristol Bay. 
Kirk LaGory received his Ph.D. in Zoology from Miami University in 1984. He has over 20 years experience in environmental assessment and over 30 years experience in ecological research. He has worked on a wide variety of projects examining the impacts of human activities on terrestrial, aquatic, and wetland ecosystems and threatened and endangered species. Recent projects include developing operational strategies to minimize the effects of hydropower operations on endangered fishes of the Colorado River basin while maintaining generation capabilities; determining priorities for geomorphology research in the Colorado River Basin; developing an inventory, monitoring, and research program for the North Slope of Alaska; evaluating the effects of the Trans-Alaska Pipeline System on ecological resources; evaluating the effects of oil shale and tar sands development on ecological resources; assessing the status and habitat use of protected species in New Hampshire; identifying indicator species to assess the effects of forest management practices; and assessing the impacts of nuclear power plant license renewal on ecological resources. He was a coauthor of the Council on Environmental Quality's guidance for considering cumulative impacts in NEPA assessments. He is the author of over 80 journal articles, book chapters, reports, and conference publications.

William Larned works for the U.S. Fish and Wildlife Service in Soldotna, Alaska. He received his B.S. in Aeronautical Science from Embry-Riddle Aeronautical University and an M.S. in wildlife biology from the University of Connecticut. He has served as a wildlife biologist/pilot for the U.S. Fish and Wildlife Service for over 30 years. From 1992 to the present he has been based in Region 7’s Waterfowl Management Division, and worked statewide, primarily conducting population assessments for listed waterfowl species (spectacled and Steller's eiders) and other sea ducks. He has also conducted aerial surveys for ducks, geese, swans, loons, grebes, and other waterbirds in Alaska, Mexico, and Russia. Mr. Larned has designed and conducted aerial waterfowl surveys throughout southwest Alaska annually since 1992. Before coming to the U.S. Fish and Wildlife Service, he was the Area Wildlife Manager for the Maryland Wildlife Administration (1972-1976). From 1976 to 1984 he conducted waterfowl population assessments in eastern and south-central U.S.; Saskatchewan and Manitoba, Canada; and Mexico. He served as biologist, pilot, enforcement officer, and fire management officer in Kenai National Wildlife Refuge, Kenai Peninsula, Alaska, from 1984 to 1992.

Wieslaw Maslowski is an associate research professor of the Oceanography Department at the Naval Postgraduate School, Monterey, California. His research interests include polar and physical oceanography, high resolution numerical ocean and sea-ice modeling, ice-oceanatmosphere interactions, ocean circulation, sea ice, and climate variability in the Arctic Ocean, sub-polar North Pacific and Atlantic, and their effects on global ocean thermohaline circulation and climate. Dr. Maslowski's recent research focus is on the dramatic decrease of the multi-year sea ice cover in the Arctic Ocean in the late 1990s and 2000s, suggesting accelerated warming trend in the northern polar climate. Results of his studies attribute some of the recent change of sea ice cover to an increased northward advection of heat from the Bering Sea via Pacific Water.

Dr. Maslowski earned his Ph.D. in physical oceanography from the University of Alaska in 1994 and M.S. degree in physical oceanography from the University of Gdansk, Poland in 1987. He is a recipient of the Naval Postgraduate School Special Act Award, NOAA Global and Climate Change Postdoctoral Fellowship, and NASA Global Change Graduate Fellowship. He 
has served on the National Academies of Science/National Research Council Committee on A Science Plan for the North Pacific Research Board, NSF Committee for the Bering Sea Initiative and the Shelf Basin Interaction Program, Arctic Region Supercomputing Center Technology Panel, Board of Directors of the Arctic Research Consortium of the U.S., and most recently on several working groups of the Second International Conference on Arctic Research Planning.

Michael F. Sigler received his Ph.D. from University of Washington in 1993 and M.S. and B.S. degrees from Cornell University in 1982 and 1979, respectively. He is currently with the NOAA Fisheries, Alaska Fisheries Science Center in Juneau, where he is a marine biologist. At the Alaska Fisheries Science Center, he has served as the Program Leader of the Habitat and Ecological Processes Research Program and as the principal investigator for several studies including Steller sea lion prey and predation studies, the southeast Alaska Steller sea lion prey study, and shark predation of Steller sea lions. He has been principally responsible for Alaska sablefish assessment, population modeling, and quota recommendations for the past 11 years. He has also served as the project leader of the Alaska sablefish longline survey for 14 years. Dr. Sigler has chaired or vice-chaired stock assessment review panels for New England, Washington-Oregon-California, Canada, and Alaska state and federal fisheries. He has served as analyst for a National Research Council review of NMFS assessment methods and has advised University of Azores (Portugal) and New Zealand scientists on survey methods and population models. He has authored numerous peer-reviewed publications on topics related to fish and marine mammal ecology.

Paul Stang is the MMS's Regional Supervisor for Leasing and Environment in Alaska, a position he took in 1997 after 30 years in Washington, D.C. From 1984 to 1997, he held various management positions at MMS headquarters after seven years as a policy analyst in the Office of the Secretary of Interior. From 1972 to 1977, he served in the coastal zone management and marine ecosystem analysis offices of NOAA. Mr. Stang began his government career with the Navy's Deep Submergence Systems Project in 1967. He has a B.A. in Arts and Letters and a B.S. in Industrial Engineering from Penn State and an M.S. in Ocean Engineering from the University of Miami/Rosenstiel School of Marine and Atmospheric Science.

Elisabeth Ann Stull received her Ph.D. from the University of California-Davis, her M.S. from the University of Georgia, and her B.A. from Lawrence University. Her academic training was in limnology, oceanography, and ecology. Her specialty is primary productivity and plankton community structure. She taught limnology and ecology at the University of Arizona prior to joining the staff at Argonne National Laboratory in 1978. She has over 25 years experience in environmental assessment, preparing assessments of aquatic and marine resources and cumulative impacts. She has directed the preparation of both small and large impact statements, and conducted field research. She has been a program manager and advisor on the requirements of the National Environmental Policy Act. She has prepared assessments of hydroelectric power, coal-fired and nuclear facilities, ocean disposal, hazardous waste incineration, assembled chemical weapons, and high-energy research facilities. She assisted in the preparation of the Council on Environmental Quality guidance on cumulative impact assessment.

Ian Voparil works as a consultant for companies within the Shell Group, offering science-based advice on environmental issues and regulations. Areas of responsibility include oceanography, 
ecological impacts of sound in water, risk evaluation, avoidance and mitigation, and spill response. Based in Houston, he has an M.S. and Ph.D. in Oceanography from the University of Maine and worked as a lecturer and researcher at the University of California-Santa Cruz in the Department of Marine Sciences before joining Shell. He has published peer-reviewed literature on the bioavailability of nutrients and contaminants and ecological constraints on digestion. He currently serves on a number of industry technical committees, including the Offshore Operators Committee. 

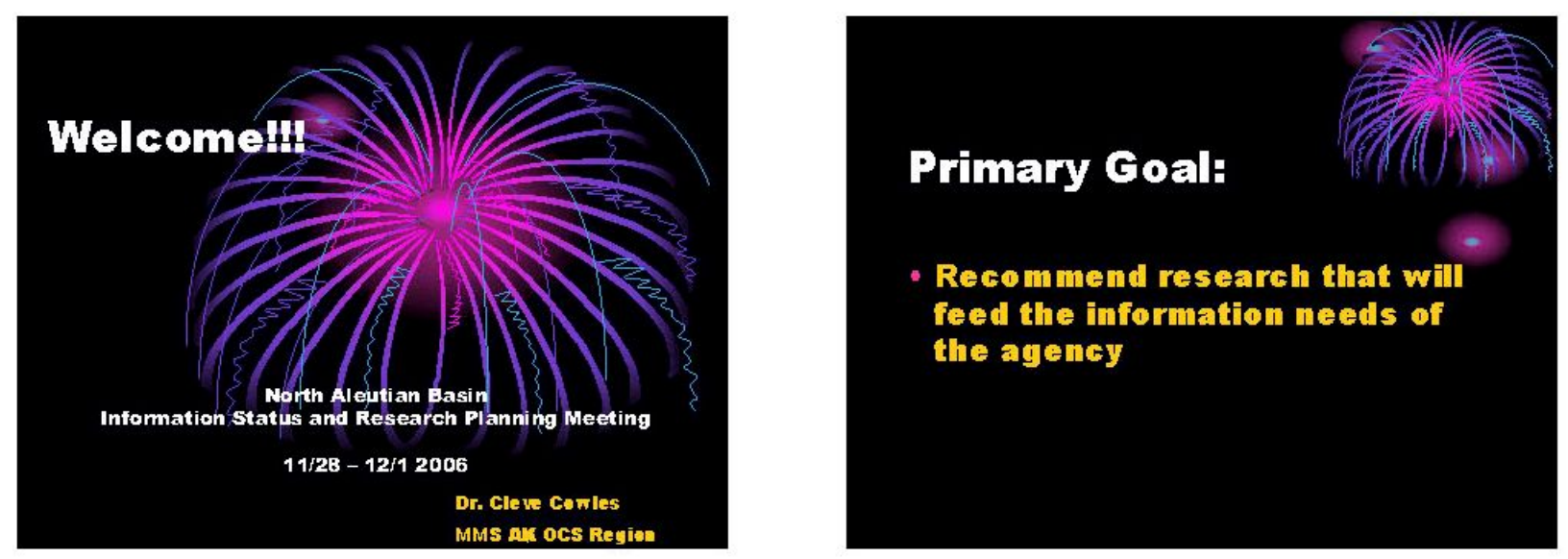

\section{Key considerations}

- Looking for mission relevance, "yood seience", hroad involvement

- Want to avoid duplication

- Ultimately looking to maximize integration among projects 

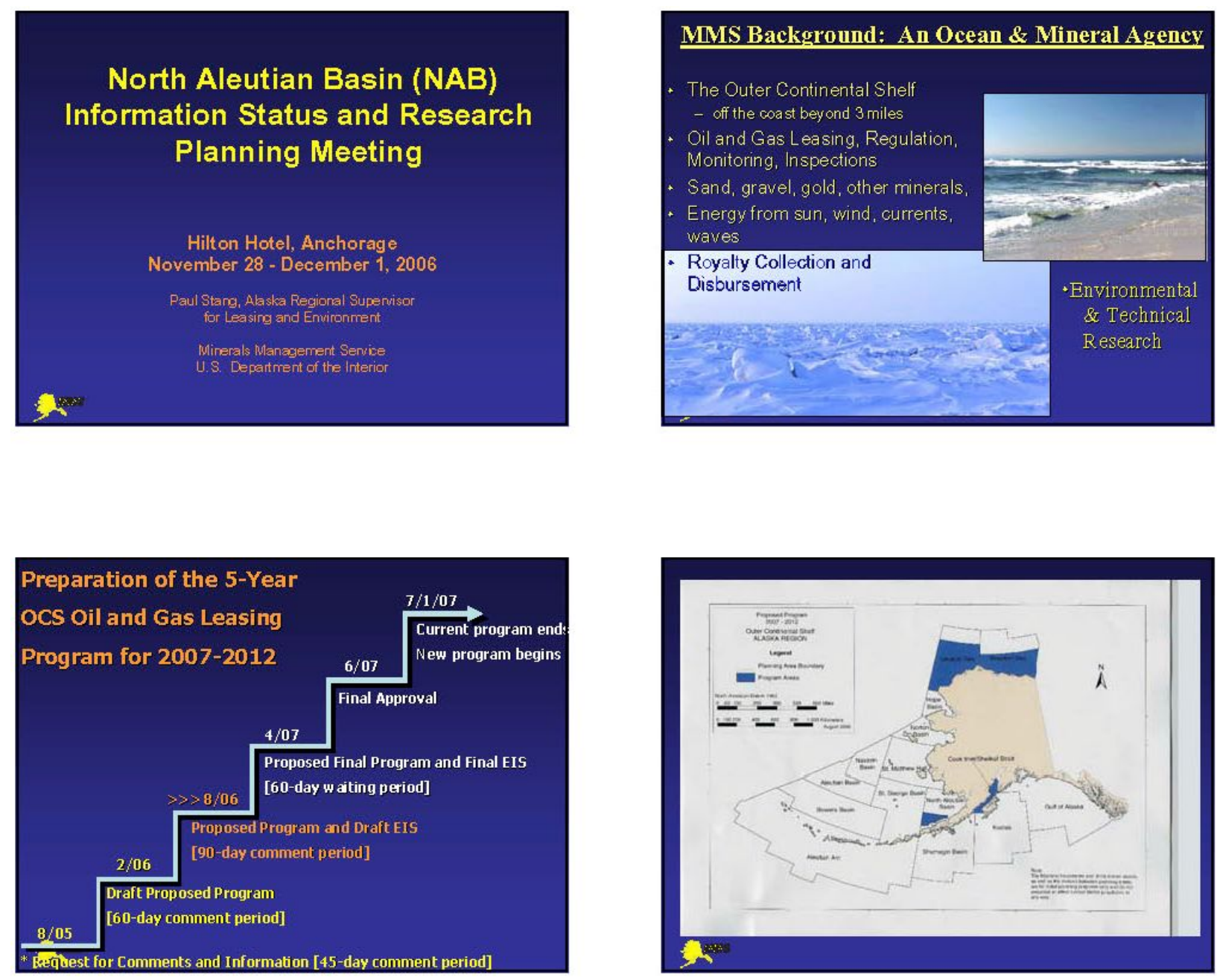

\section{Sales in the 2007-2012 Proposed Program off Alaska}

\section{Beaufort Sea \\ Cook Inlet \\ 2009 and 2011 \\ 2009 and 2011}

Chukchi Sea

2007,2010 and 2012

North Aleutian Basin

2010 and 2012 (subject to Fres. Withdrawal)

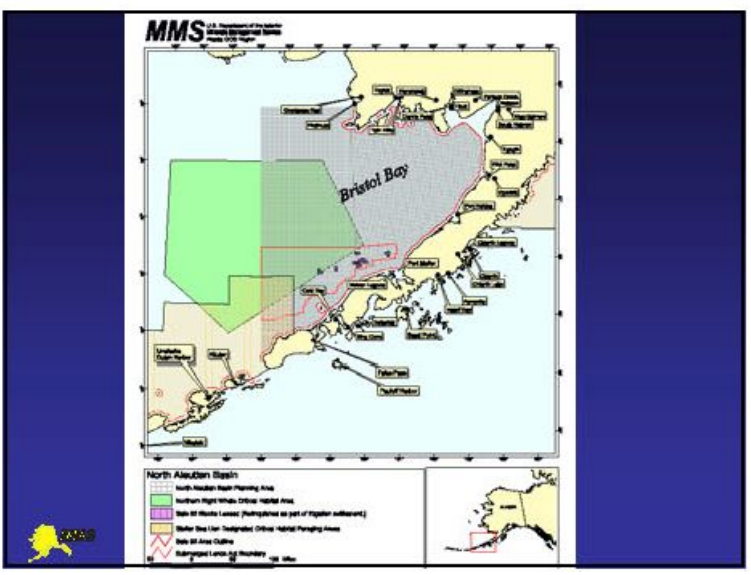




\section{Historic Sale 92 Area}

- Last area sale was held in 1988

- Last EIS for NAB area was completed in 1985

- Last MMS study in the area was concluded in early 1990 s

x

\begin{tabular}{|c|c|c|c|c|}
\hline \multicolumn{5}{|c|}{$\begin{array}{l}\text { OCS Oil and Cas Estimates } \\
\text { Undiscovered Technically Recoverable }\end{array}$} \\
\hline \multirow{2}{*}{ Planning Area } & \multicolumn{3}{|c|}{ Barrels* of Oil Equivalent } & \multirow{2}{*}{$\begin{array}{l}\text { Fraction } \\
\text { that's oil }\end{array}$} \\
\hline & $\underline{95 \%}$ & Mean & $\underline{5 \%}$ & \\
\hline Beaufort Sea & 0.53 & 13.14 & 36.08 & $2 / 3^{* *}$ \\
\hline Chukchi Sea & 4.15 & 29.04 & 77.36 & $1 / 2^{* *}$ \\
\hline N. Aleutian Basin & 0.09 & 2.29 & 6.65 & $1 / 3^{* *}$ \\
\hline Cook Inlet & 0.06 & 1.23 & 3.47 & $4 / 5^{* *}$ \\
\hline${ }^{*}$ Billions & & & ${ }^{* *} \mathrm{App}$ & roximate \\
\hline
\end{tabular}

\section{Some Key Concerns raised in} meetings on Aleutian Chain

- Effects of noise and oil spills on --

- Commercial fisheries year round

- Subsistence

- Endangered and Threatened Species

- Other Birds and Mammals

- Right Whale \& Stellar Sea Lion Critical Habitats

- Economic Benefits - Jobs \& Access to Fuel

\section{Proposed leasing is still contingent on ...}

- Inclusion in the Final 5-Year Program

- Removal of current Presidential Withdrawal

- Subsequent pre-sale decisions on whether to actually hold an individual sale in the NAB

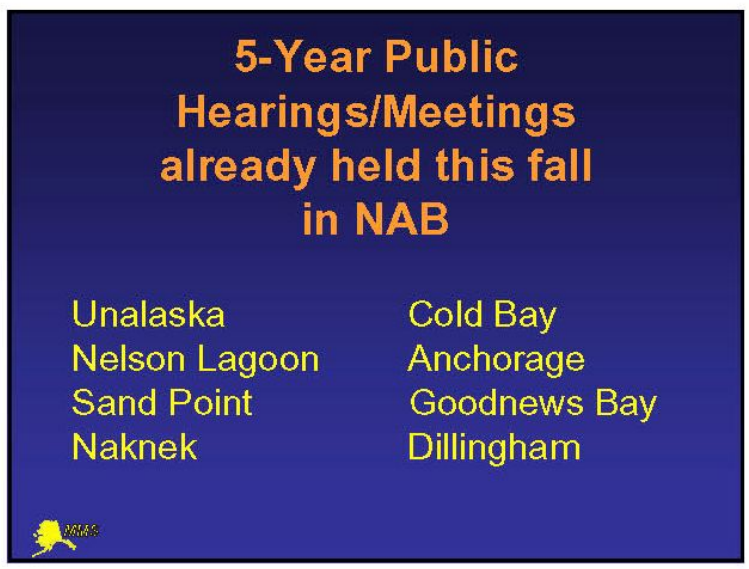

Timing Est. of Information Needs for OCS Leasing / Operational Activities

- Fall '07 - Need Studies Info to Start Lease Sale EIS

- 2008 - Start general monitoring in sale area

- 2010 - Lease sale

- $2011^{*}$ - First Exploration Well \& First Discovery

- $2012^{*}$ - Need Studies Info to Start DPP EIS

- $2012^{\star}$ - Start Monitoring in Development Area

- $2015^{*}$ - Complete EIS, Approve DPP, Sanction Project

- $2017^{*}$ - Begin Development Construction at NAB site

- $2020^{*}$ - Start Oil Production

- $2025^{*}$ - Start Gas Production (LNG Export) 


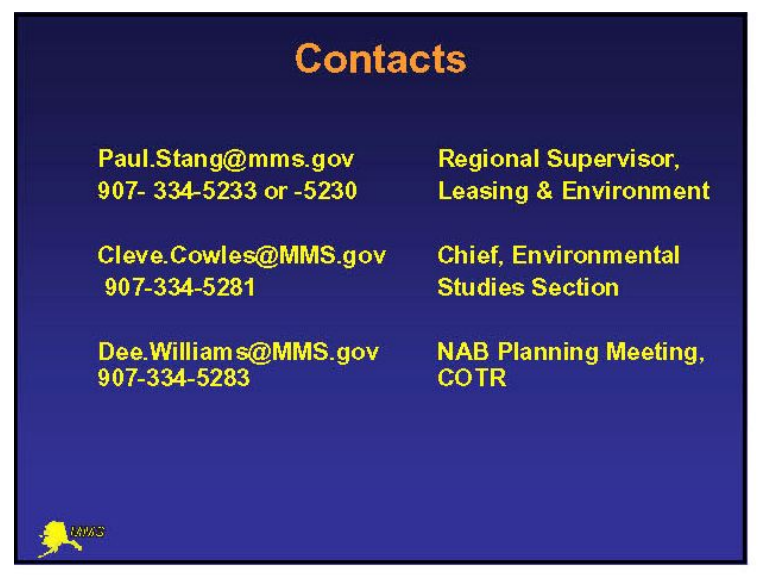




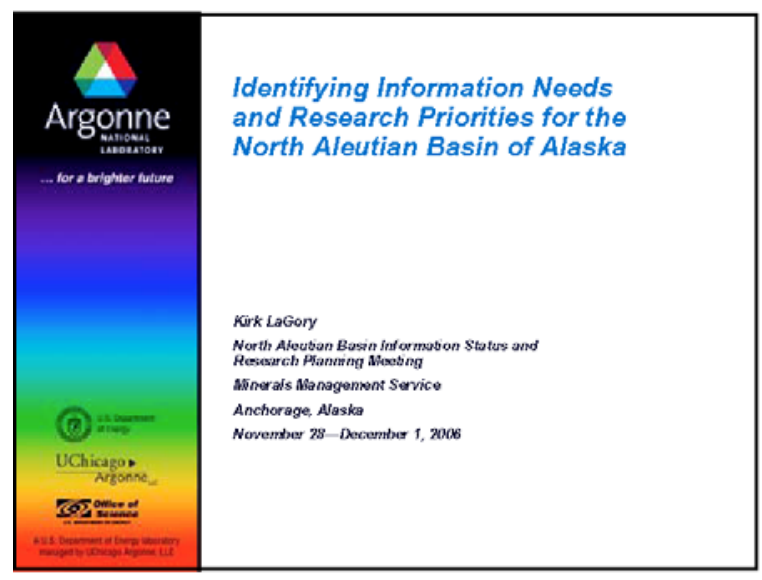

\section{Meeting Goal}

- Recommend research to support an assessment of the potentiol environmental impacts of oil and gas development in the North Aleutian Basin program area on marine, coastal, and human resources

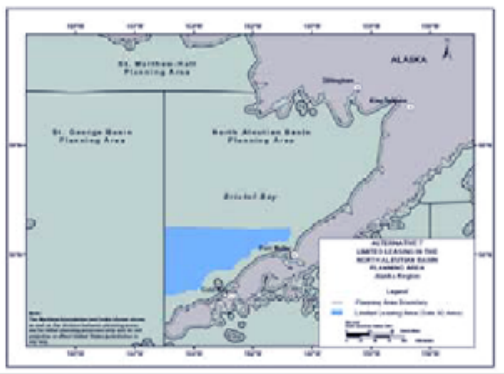

Studies Will Be Used to Support Assessments Related to Proposed Lease Sales

- Two proposed lease sales-2010 and 2012

- Each requires an assessment of different phases of activities EIS prior to sale

- Post-lease EA on exploration activities

- EIS of construction and operations

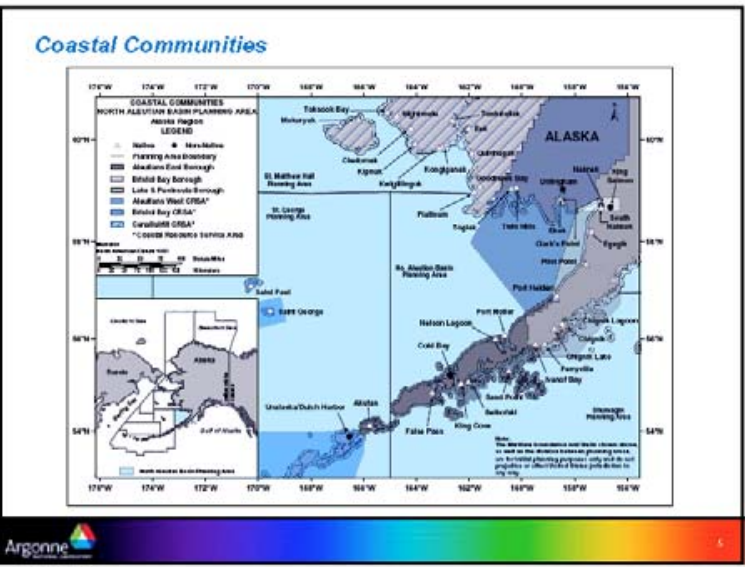

The North Aleutian Basin Contains Important Resources

- Ecologically important aree

Fish and shellish populations

- Seabirds and waterfowl

Marine mammals, including the endangered northern right whale and Steller sea lion and threatened sea otter

- Coastal communities that depend on resources of the Basir

- Cultural resources

- Commercial fisheries

- Subsistence resources

Refuges, Parks, and Preserves

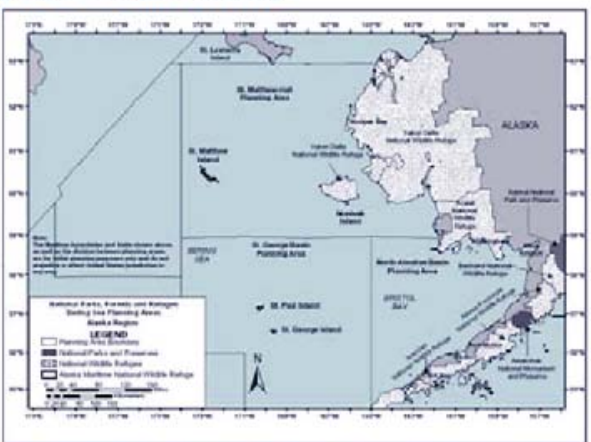




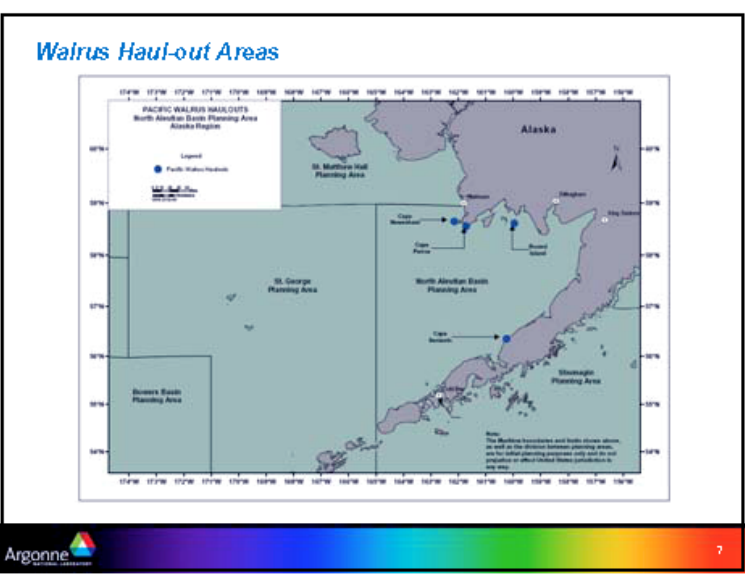

Steller SeaLion Rookeries and Haul-out Areas

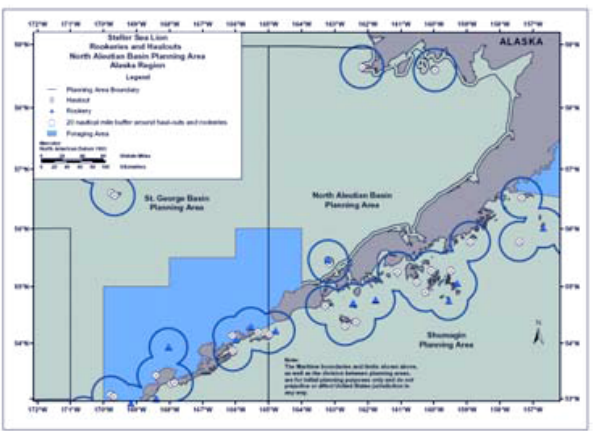

Meeting Overview

- Day 1: Presentations by researchers in relevant topical areas

- Day 2 and 3: Ereakout sessions for five working groups

- Physical oceanography, ecosystems, oil spill fate and effects

- Socioeconomics, subsistence, local and traditional knowedge

- Fish and comm ercial fisheries

Birds

- Marine mammals

- Day 4: Presentation of working group results

- Working Groups are asked to develop specific study profiks

- MMS will prioritizeand fund study projects in the aree, beginning in FY07

Several Types of Studies Can Be Considered

- Analyses of existing data sets

- Resource inventories

- Studies oftrends in status and distribution

- Targeted research to address topical areas

- Model development

- Database development
Elements of MMS Study Profiles

- Need for study and relevance to MMS mission

- Study objectives including hypotheses to be tested

- Methods

- Timing induding start date and duration

- Cost and level of effort

impact Analysis Terminology

Oil and Gas Development

Activity P hase (e.g., exploration, construction, operations, decommissioning)

> Activity (e.g., seismic surveys, drilling, trenching)

Impading Fador (e.g., noise, disturbance of substrate, traftic, accidents)

Affected Resource (e.g., species, habitats, economy, subsistence use)

Affected Resource Attribute (e.g., species life stage, special use areas, jobs, hunting, recreational fishing) 


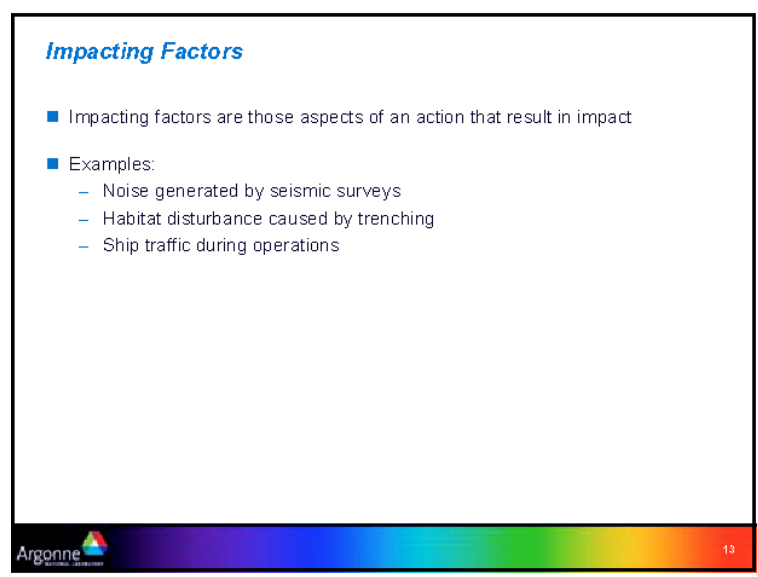

\section{Resource Attributes}

- Resource attributes are those characteristics of the resource that are of greatest concern or importance for sustainability

\section{- Examples:}

Migration pathways

- Food resources

Breeding areas

- Important life stages
Considerations for Identifying Information Needs and Recommended Studies

- Need to view North Aleutian Basin as a "system" of interdependent parts

- Focus on important parts (resources) of the system that are relevant to assessment of impacts

Which resources could be most affected by oil and gas development actions?

Which activities and impacting factors could have the most important effects?

What other factors could affect the resources of interest?

- Look for opportunities to identify representative species or groups for study

\section{Resources}

- Resources are biological, physical, cultural, and socioeconomic components of the Basin

- Examples:

- Sea otter

- Groundfish

- Nearshore ecological communities

Demographic patterns

Subsistence

Jobs

- Public services

\section{Simple Impact Mode}

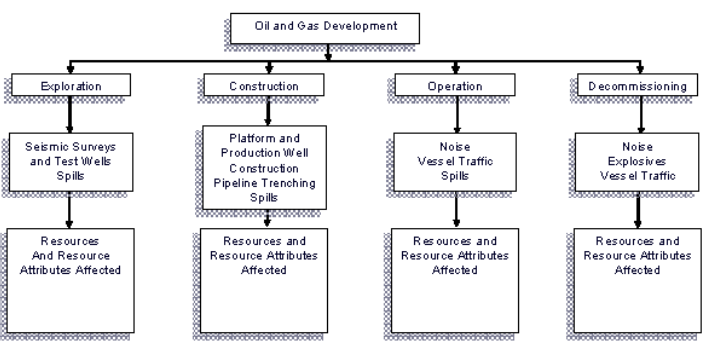

We Wilf Focus on a Series of Questions to Arrive at Study Recommendations

What aspects of oil and gas development could affect resources in the Basin?

What are the important resources of concern in the Basin?

3. What are the important resource attributes for consideration?

What are the most important oil and gas impacts that affect resources of concern?

5. How well do we understand each resource in the Basin and the potential effects of oil and gas development? 


\begin{tabular}{|l|}
\hline Prioritization \\
- What makes a resource or resource attribute important? \\
- Ecological value \\
. Importance to system \\
Sustainabifity of resource or system \\
- Rarity \\
- Economic value \\
- What makes or cultural value \\
- Duration impacting factor important? \\
- Magnitude \\
- Spatial extent of effect \\
- Importance of the resource affected \\
\end{tabular}




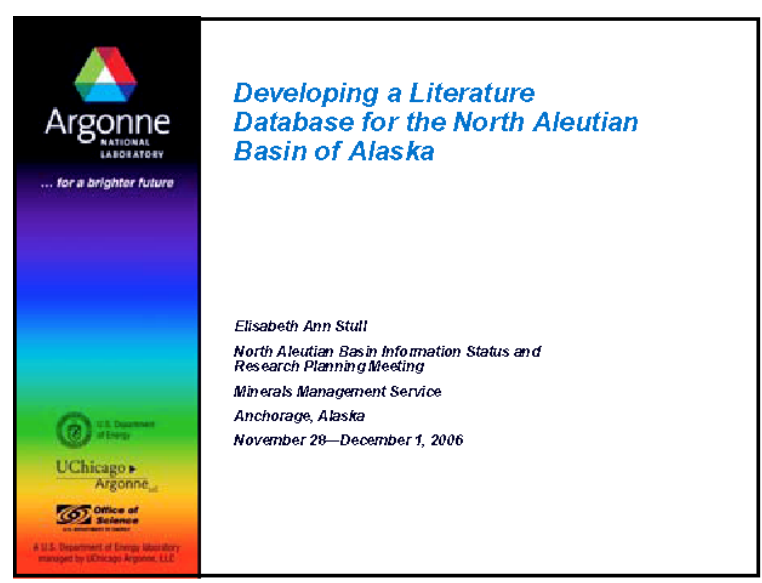

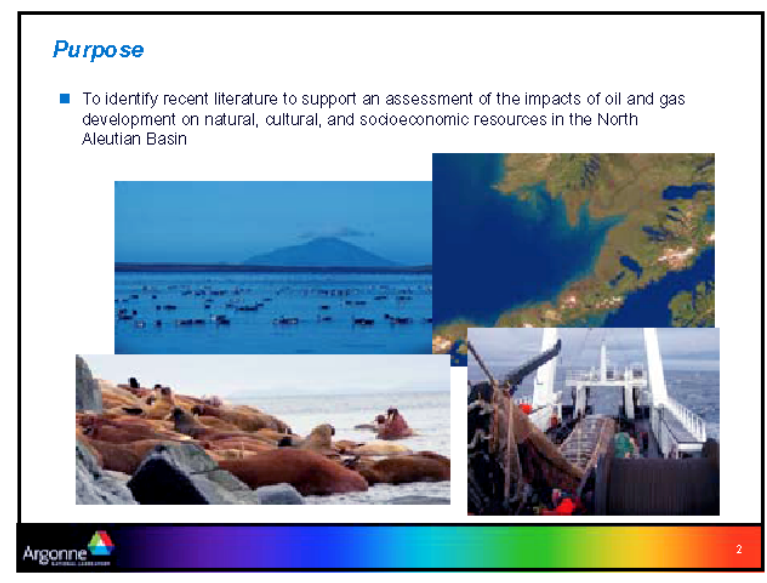

Many Types of References were Identified and Collected
- Workshop and symposium proceedings
- Personal Web pages
- Web pages of non-governmental organizations
- Web pages of governmental organizations
- Environmental impact studies
- Books and articles reporting research results
- Regulatory documents
- Technical reports
- Newspapers and newsletters
- Theses and dissertations

\section{Argonne 4}

1278 References were Found; $63 \%$ in Electronic Formats

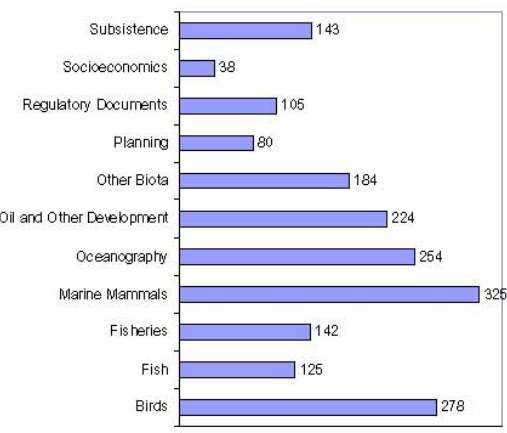

The Database was Organized into Eleven Topical Areas

- Oceanography (Biological, Chemical, and Physical) and Other Physical Sciences

- Marine Mammals

- Birds

- Fish and Shellfish

- Other Biota and Community/Ecosystem Studies

- Effects of Oil/Gas and Other Development

- Fisheries

- Subsistence, Traditional Knowledge, and Other Related Topics

- Socioeconomics

- Resource and Research Planning

- Studies Related to Regulatory Requirements

\section{Argonne 4}

References were Colfected for the Years 1996 through 2006

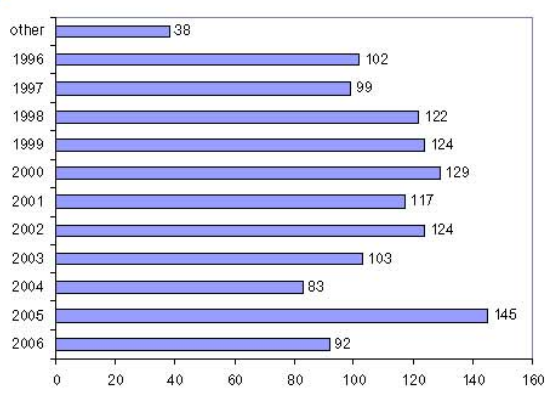


Oceanography (Biological, Chemical, and

Physical) and Other Physical Sciences

- Major Topics:

- Dynamics of the Bering Sea, the Bering Sea ecosystem

Interactions between oceanographic regions (Bering Sea, Chukchi Sea, Beaufort Sea)

Currents in and around the Aleutian Chain

- Effects of global warming.

- Little information was found on

Bristol Bay nearshore

- Benthic and intertidal areas

Birds

- Major topics:

- Waterfowl abundance, distribution, breeding

- Seabird by-catch

- Seabird colonies

Effects of petroleum spills

- Contaminant concentrations and effects

- Subsistence harvest

- Species most studied:

Eider species

- Kittlitz's murrelet

Other Biota and CommunitylEcosystem Studies

- Community and ecosystem studies

- Phytoplankton and plankton productivity of the Bering Sea

- Relationships of groups of organisms to habitats

- Cumulative impacts

- Factors structuring communities and ecosystems

- Benthic organisms

Wild life studies

- Impact of oil spills on communities and ecosystems

\section{Marine Mammals}

- Major Topics included:

- Surveys, distribution, abundance, migration and movement

Diet and food supply

- Impact of human activities

- Population trends

- Subsistence use and traditional knowledge

- Species most studied:

- Right, fin, bowhead whales

- Walrus

- Sea otter

- Polar bear

- Geographic Area: Bering Sea and North Pacific

- Little Information was found on

- Populations in the immediate vicinity of potential oil/gas development activities.

Fish and Shellfish

- Major topics

- Population dynamics

- Migration

- Abundance and distribution

- Recruitment

- Major species studied

- All salmon species

- King and tanner crabs

- Pacific herring

- Walleye pollock

Effects of OillGas and Other Development

- Oil spill history and impacts

- Selendang Ays

- Exxon Valdez

- Assessments of oil development impacts

- Population abundance after oil spills for birds and mammals

- Effects of disturbance from development activities

- Collisions, both with respect to birds and mammals

- Pollutant concentrations in biota

- Effects of fishing on biota, including birds and mammals 


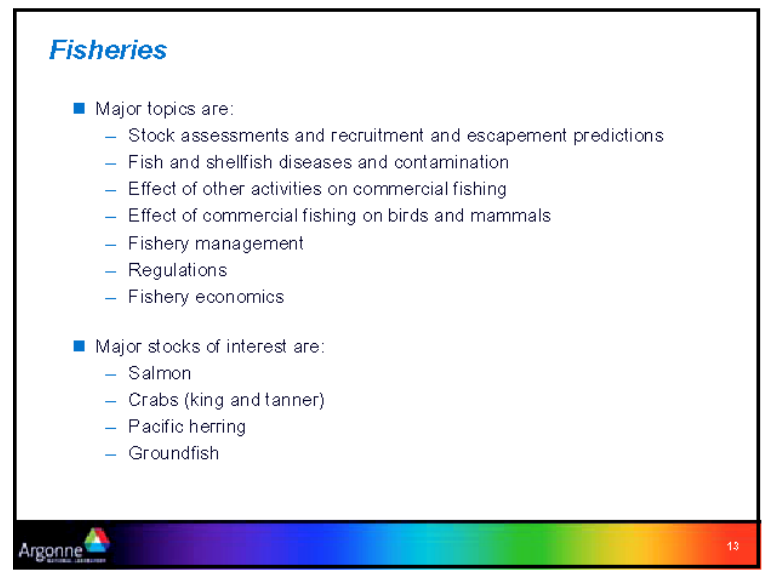

Subsistence, Traditional Knowledge, and Other Related Topics

- Major topics include:

- Subsistence harvest of plant products, fish, birds, and mammals

- Wild foods: identification and use

- Surveys of subsistence practices

- Native management of resources important in subsistence

- Traditional knowledge of resource abundance, trends, and ecology

- Regulations

\section{Studies Related to Regulatory Requirements}

- Types of documents include:

- Regulations

- Regulatory analysis

- Environmental assessments and impact statements

housing, government

- Resource economics

- Infrastructure development (i.e. harbors, community services)

Borough and Native governments and corporations

- Community planning

- Developing industries

- Mineral resources

- Endangered Species Act determinations

- Critical habitat determinations

- Recovery plans for endangered species

- Biological Opinions prepared pursuant to the Endangered Species

- Bering Sea impacts study (BESIS)

- Western Arctic shelf-basin interaction study (SBI)

- Gulf of Alaska Ecosystem Monitoring and Research Plan

- Eastern Bering Sea (BASIS) coastal research

Conchusions
There are many recent studies of the Bering Sea area.
- Research emphasis has been placed on:
. Wider regional issues
- Global climate change
. Marine mammal species
. Faterfowl and protected bird species
- There is less research activity in certain areas, such as
- In areas adjacent to proposed oil'gas development locations
- Benthic and coastal communities and ecosystems
- You will be able to identify areas which should high priorities for future
research related to oil/gas development in the North Aleutian basin.


Potential Financial and Employment Impact from the Development of Oil \&

Gas in the North Aleutian Basin

Shell Offshore Inc. Anchorage, Alaska

October, 2006

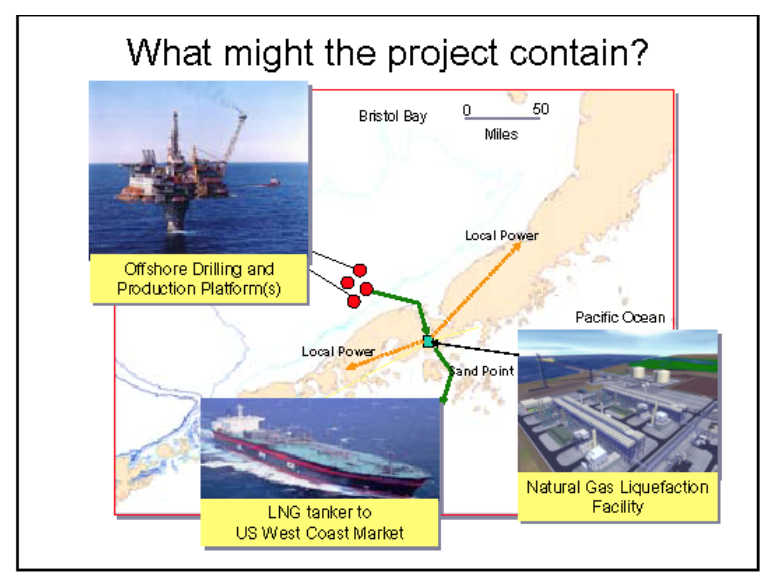

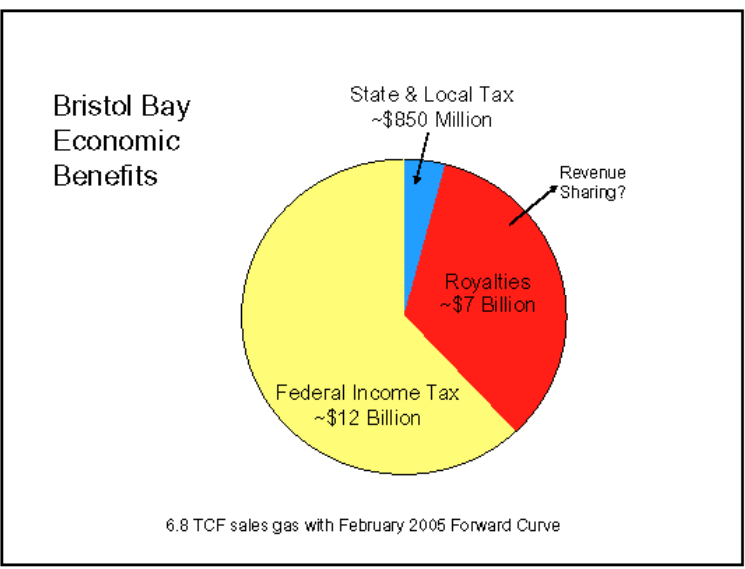

\section{Jobs: Offshore Operations \& Onshore LNG Facility}

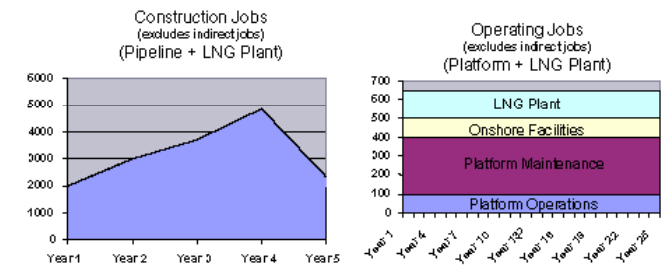

\section{Typical LNG Plant Personnel}

\begin{tabular}{|c|c|}
\hline \begin{tabular}{|l|} 
Category \\
Staff Positions
\end{tabular} & Plan (two crews) \\
\hline \begin{tabular}{|l} 
Oudishore Installation Manager \\
Offs
\end{tabular} & 2 \\
\hline Process Team Leader & 2 \\
\hline Utilities Team Leader & \\
\hline Process Staff As sociate & 2 \\
\hline Resource Coordinator & $\overline{2}$ \\
\hline Marine Supervisor & 2 \\
\hline Graft Positions & \\
\hline $\begin{array}{l}\text { Instrumentation Technician } \\
\text { Electrician }\end{array}$ & 4 \\
\hline $\begin{array}{l}\text { Electrician } \\
\text { Electronic Technician }\end{array}$ & $\frac{4}{4}$ \\
\hline Mechanic & 6 \\
\hline Production Operator & 16 \\
\hline Total & 46 \\
\hline
\end{tabular}

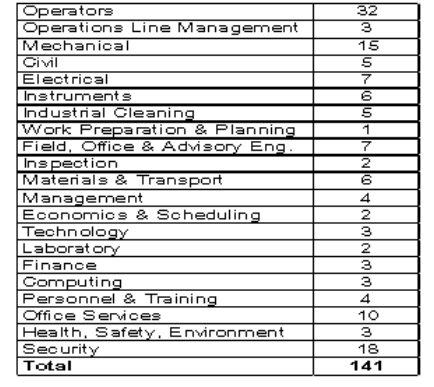




\section{Shell US Operations Workforce Strategy}

- Recruit Talent

- Community \& Technical Colleges and Universities - Partner with scholarships and outreach programs

- Participate in Industry Advisory Committees and Organizations (e.g. Center for the Advancement of Process Technology (CAPT), Process Technology Degree Programs

- Operations leadership involved with schools

- Develop Local Source

- Focus on schools in areas of operation (Gulf of Mexico, Rockies, Texas, Alaska)

- Invest in local schools and programs

- Seek Diversity

- Actively promote our industry in high schools and colleges

- Fund and partiapate in programs to attract local talent

\section{Educational Expectations}

- Offshore Installation Manager

- Process Team Leader

- Utilities Team Leader

- Process Staff Associate

- Resource Coordinator

- Marine Supervisor
- Associate to Bachelors Degree

- Significant offshore operations experience

- Continuing Education - In-House courses - Shell / Industry approved CE courses - Shell Leadership Training

- Pertinent License as required

\section{Educational Expectations}

- Automatic Control Repairman

- Electrician

- Electronic Technician

- Computer Assisted Operations

- Mechanic

- Operator
- Associate to Bachelors Degree

- Continuing

Education

- In-House courses

- Shell / Industry approved $\mathrm{CE}$ courses

\section{Support Positions}

- Catering Crew

- Helicopter Landing Officer

- Medical Technician

- Clerk / Office Administrator

- Logistics Clerk

Comments: These positions are usually contract positions. Education varies for each job and may require special licenses. 


\section{Oil and Gas Contractors}

- Health, Safety, Environment

- Spill Response, Emergency Response

- Well Services

- Drilling, Coning, Logging, Completion, Production, Recompletion, Abandonment

- Platform Services

- Equipment Start-up, Maintenance, Renewal, Removal

- Logistics handling

- Helicopter, Crew Boats, Equipment Barges, etc.

- Pipe and Materials

- Fabrication, Transport, Loading, Installation,

Maintenance, Removal

\section{Community Employment}

- Services

- Hotels, Restaurants, Transportation

- Emergency (Police, Fire Departments)

- Infrastructure (Schools, Communications, Power

Transportation, Water and Sewage, Waste Management)

- Governmental Agencies

- Real Estate, Construction, etc

- Goods

- Food, Fuel, Homes, Vehicles

- Clothing, Household items, Office Products

\section{Employment and Compensation Impact}

\begin{tabular}{|l|r|r|rr|rr|}
\hline \multicolumn{1}{|c|}{ Category } & Ratio & Total Count & $\begin{array}{c}\text { Average Salary per } \\
\text { person per year }\end{array}$ & $\begin{array}{c}\text { Total Compensation } \\
\text { per Category pery ear }\end{array}$ \\
\hline Operator \& Contract Staff & 1 & 650 & $\$$ & $* * 85,000.00$ & $\$$ & $55,250,000,00$ \\
\hline Community & $*$ & 3900 & $\$$ & $* * 38,000,00$ & $\$$ & $148,200,000.00$ \\
\hline Total & & 4550 & $\$$ & $123,000.00$ & $\$$ & $203,450,000.00$ \\
\hline
\end{tabular}

* Scott Goldsmith (ISER) - University of Alaska Anchorage

** Based on Kenai Peninsula data, 2005 - 2006 

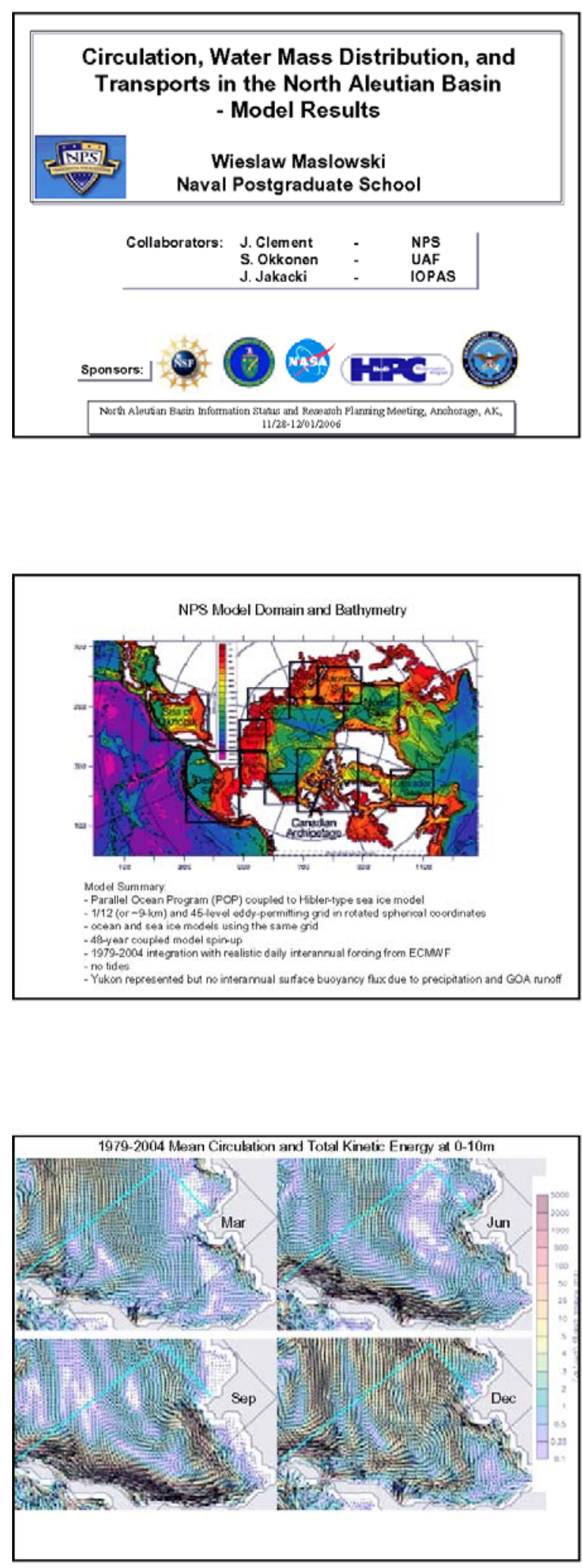

\section{Outline}

1. Domain Requirements for Study

2. Mean, Seasonal and Interannual Circulation

3. Mass and Property Transports

4. Salinity and Temperature Distribution

5. Sea Ice Conditions, Variability, and Impacts

6. Fate of Tracers

7. Summary
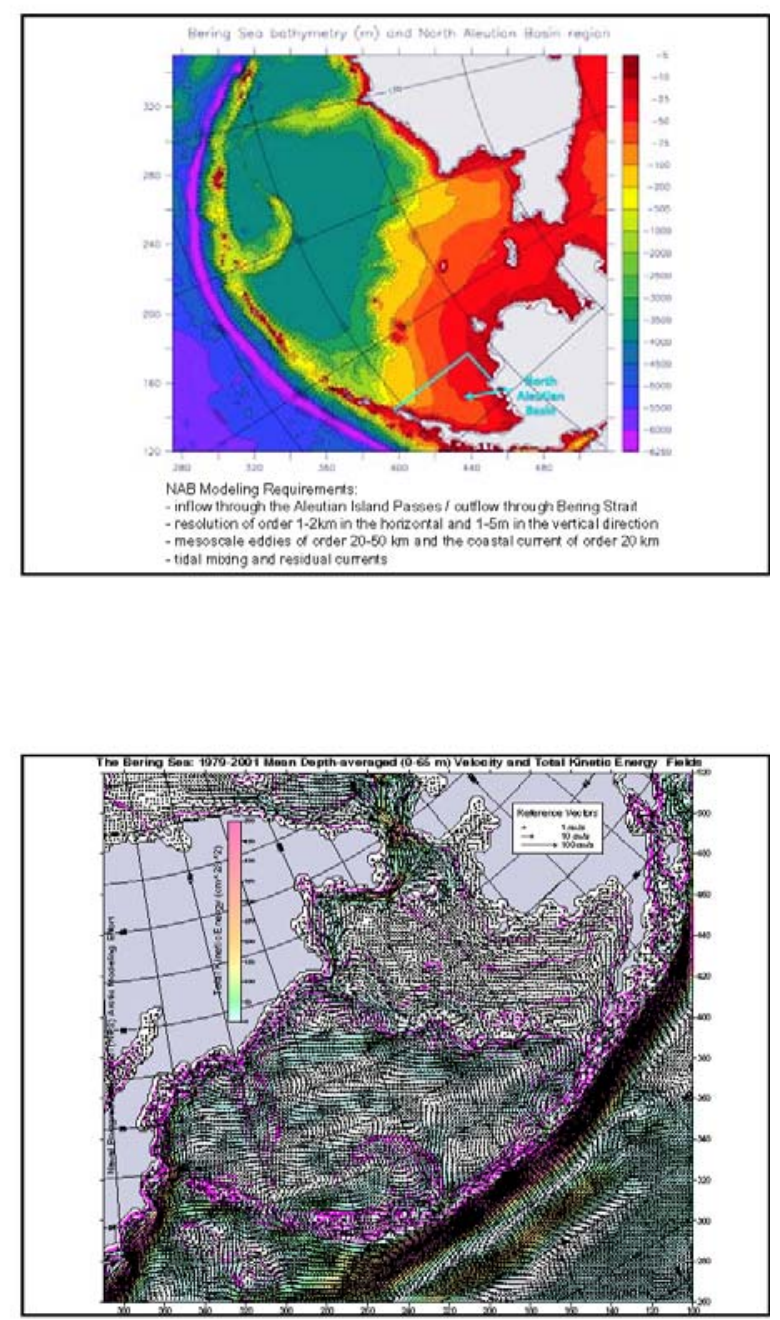

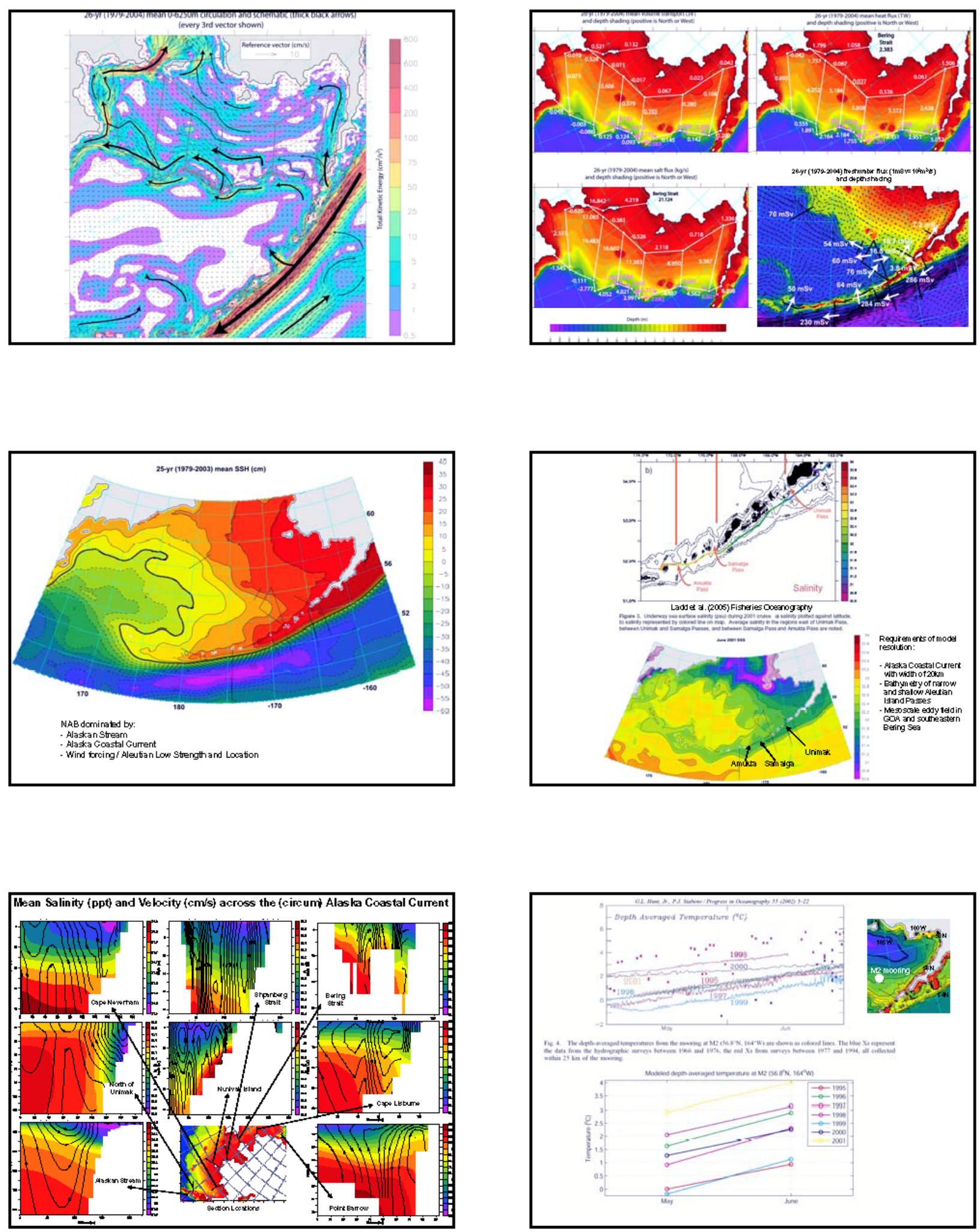

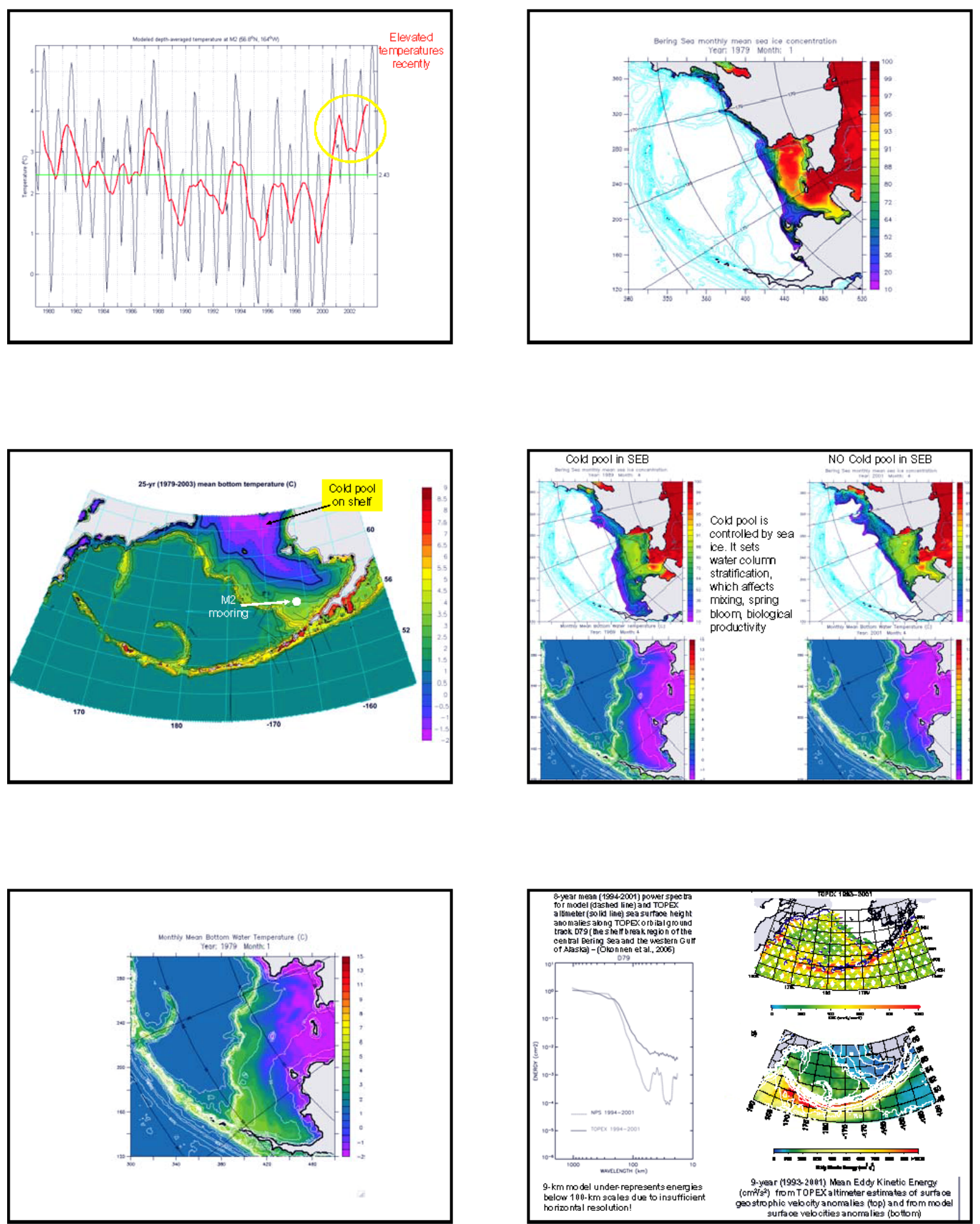


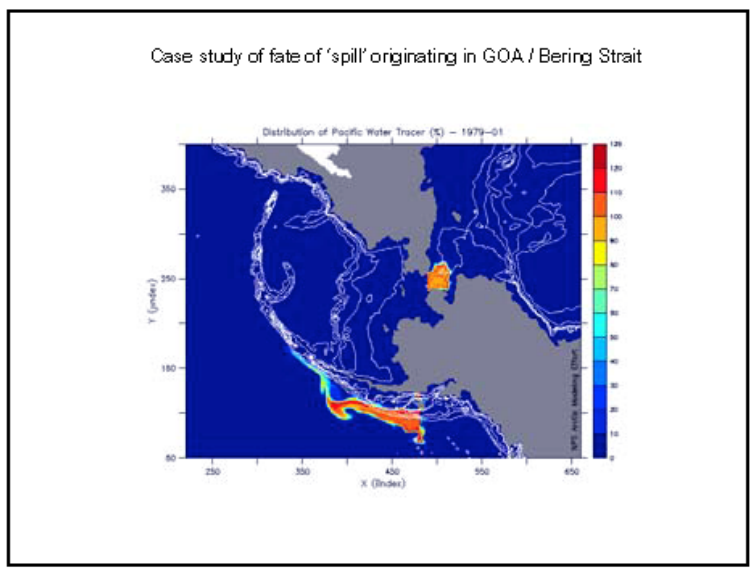

Case study of fate of 'spill' originating in the S-W NAB
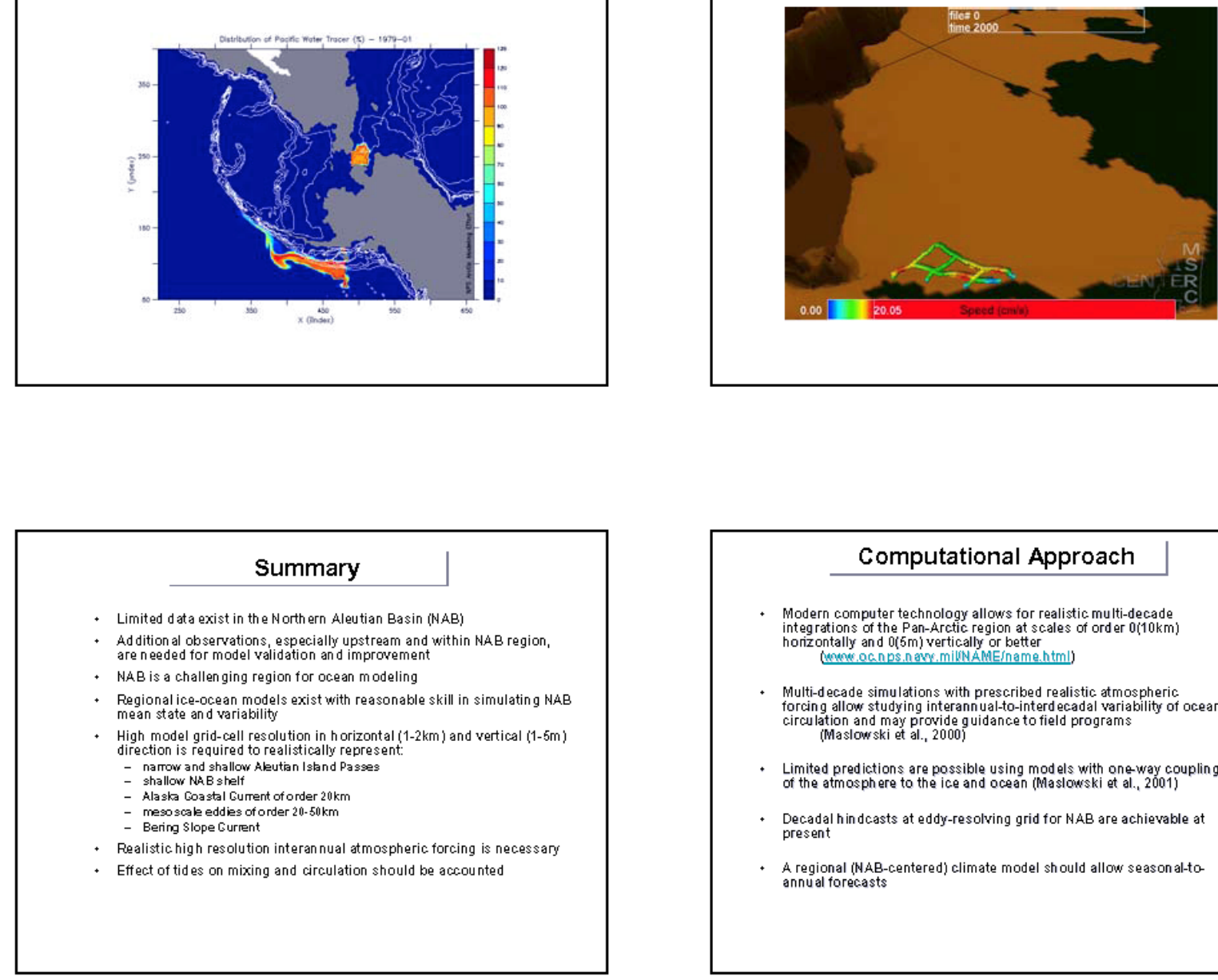

\begin{tabular}{|c|c|}
\hline & Computational Approach \\
\hline + & 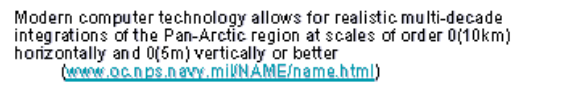 \\
\hline & $\begin{array}{l}\text { Multi-decade simulations with prescribed realistic atmospheric } \\
\text { torcing allow studying interannual-to-interdecadal variability of ocean } \\
\text { circulation and may provide guidance to field programs } \\
\text { (Maslow ski et al., 2000) }\end{array}$ \\
\hline & $\begin{array}{l}\text { Limited predictions are possible using mod els with one-way coupling } \\
\text { of the atmosphere to the ice and ocean (Maslowski et al., 2001) }\end{array}$ \\
\hline & $\begin{array}{l}\text { Decadal hindcasts at eddy-resolving grid for } \mathrm{NAB} \text { are achievable at } \\
\text { present }\end{array}$ \\
\hline & $\begin{array}{l}\text { A regional (NAB-centered) climate model should allow season al-to- } \\
\text { annual forecasts }\end{array}$ \\
\hline
\end{tabular}

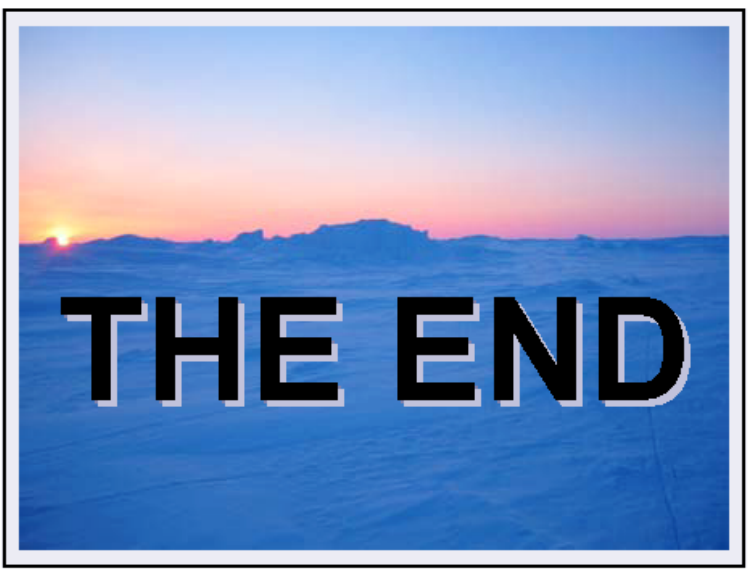


Marine Fish Abundance and Distribution in the MMS North Aleutian Basin Program Area (southeast Bering Sea)

- Michael Sigler

- Program Leader, Habitat and Ecological Processes Research (HEPR) Program

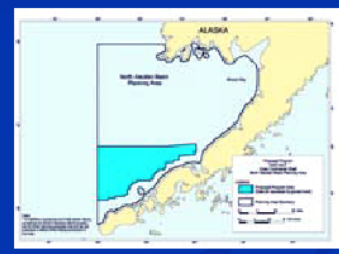

\section{What information is available?}

- Fisheries data

- Survey data

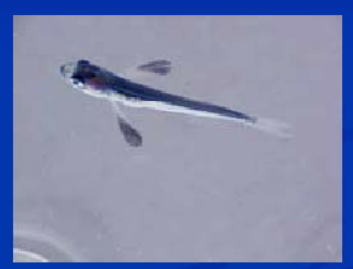

\section{Outline}

- What information is available?

- What information is needed for this area?

- What uncertainties should be addressed first?

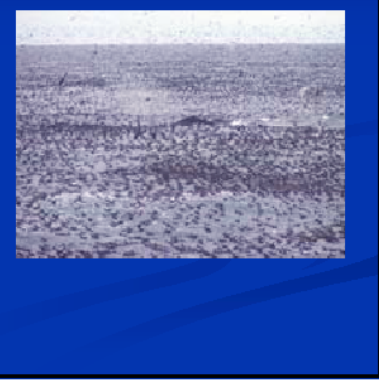

\section{Pollock catch}
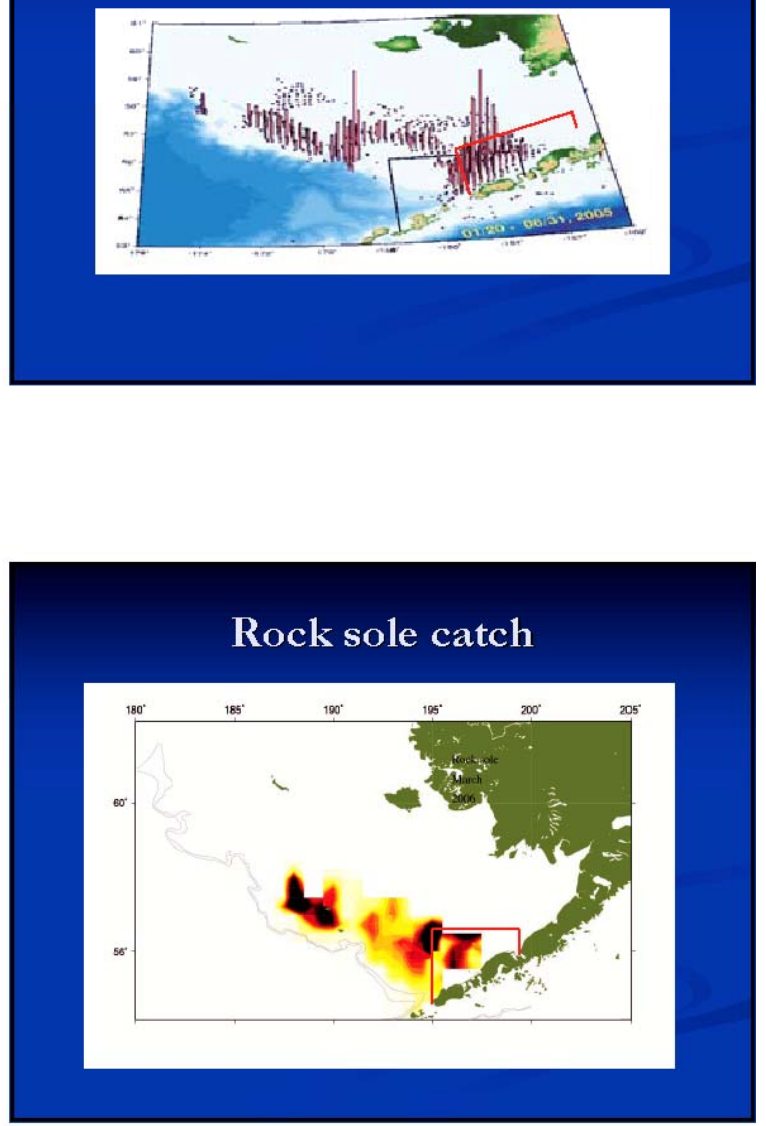

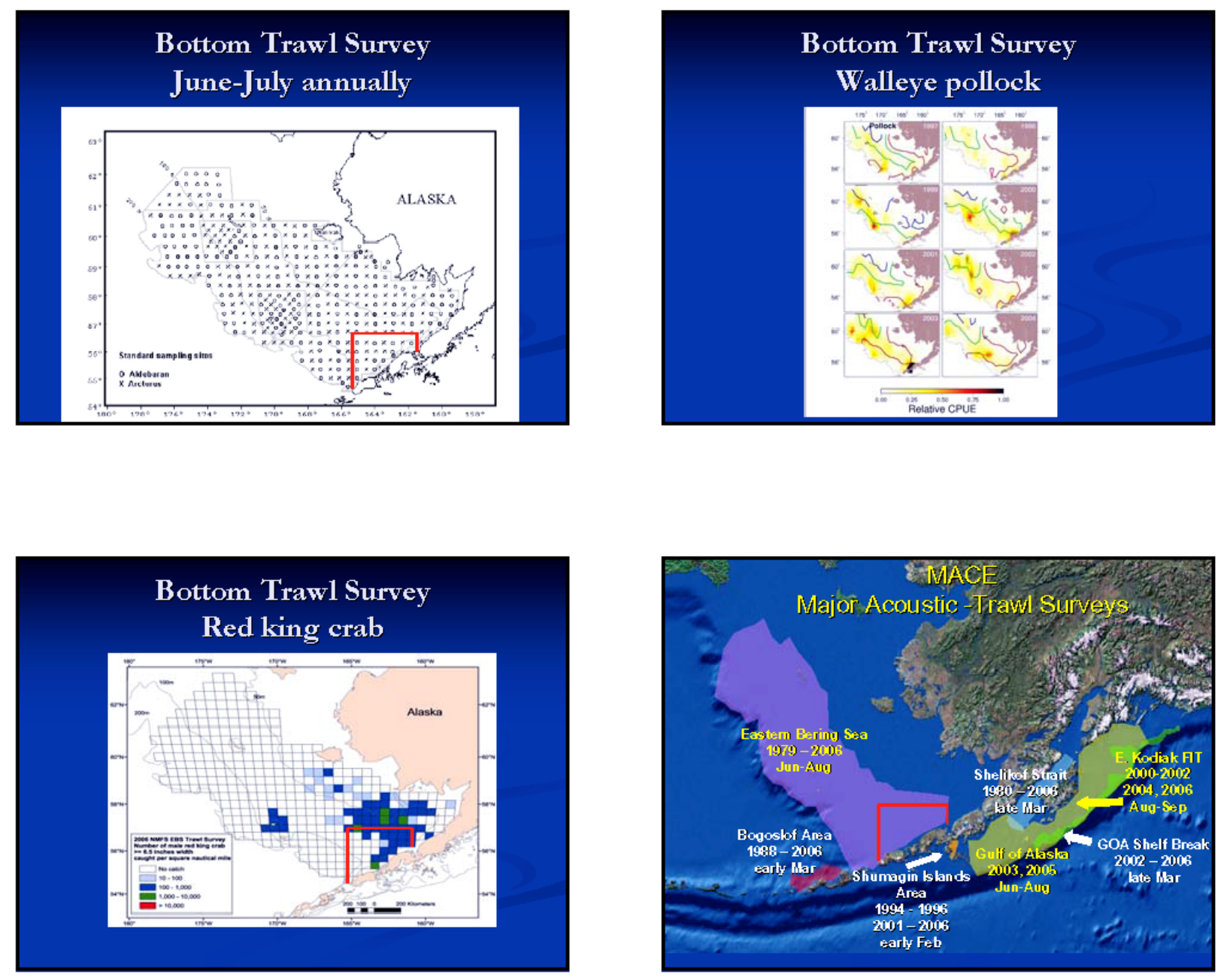

Acoustic-midwater Trawl Survey June-July biennially

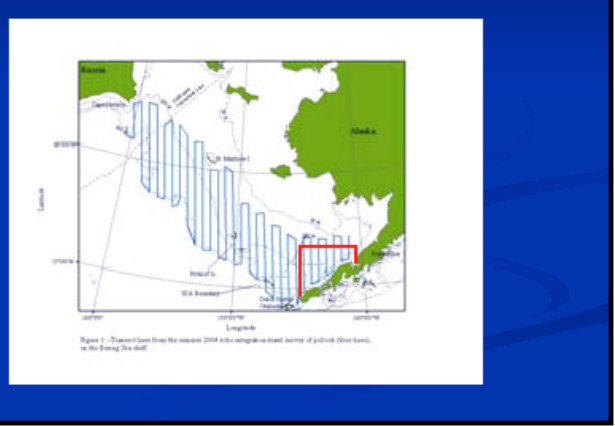

Acoustic-midwater Trawl Survey June-July biennially

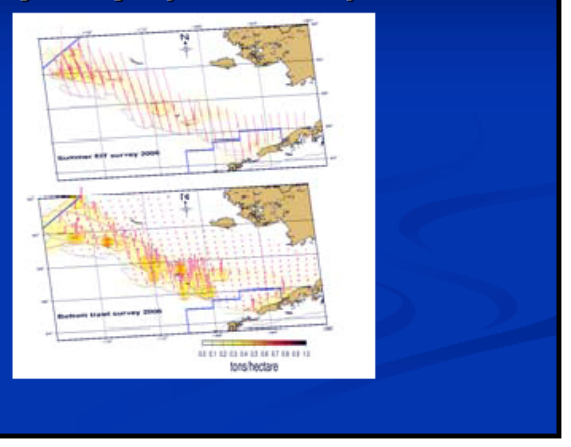



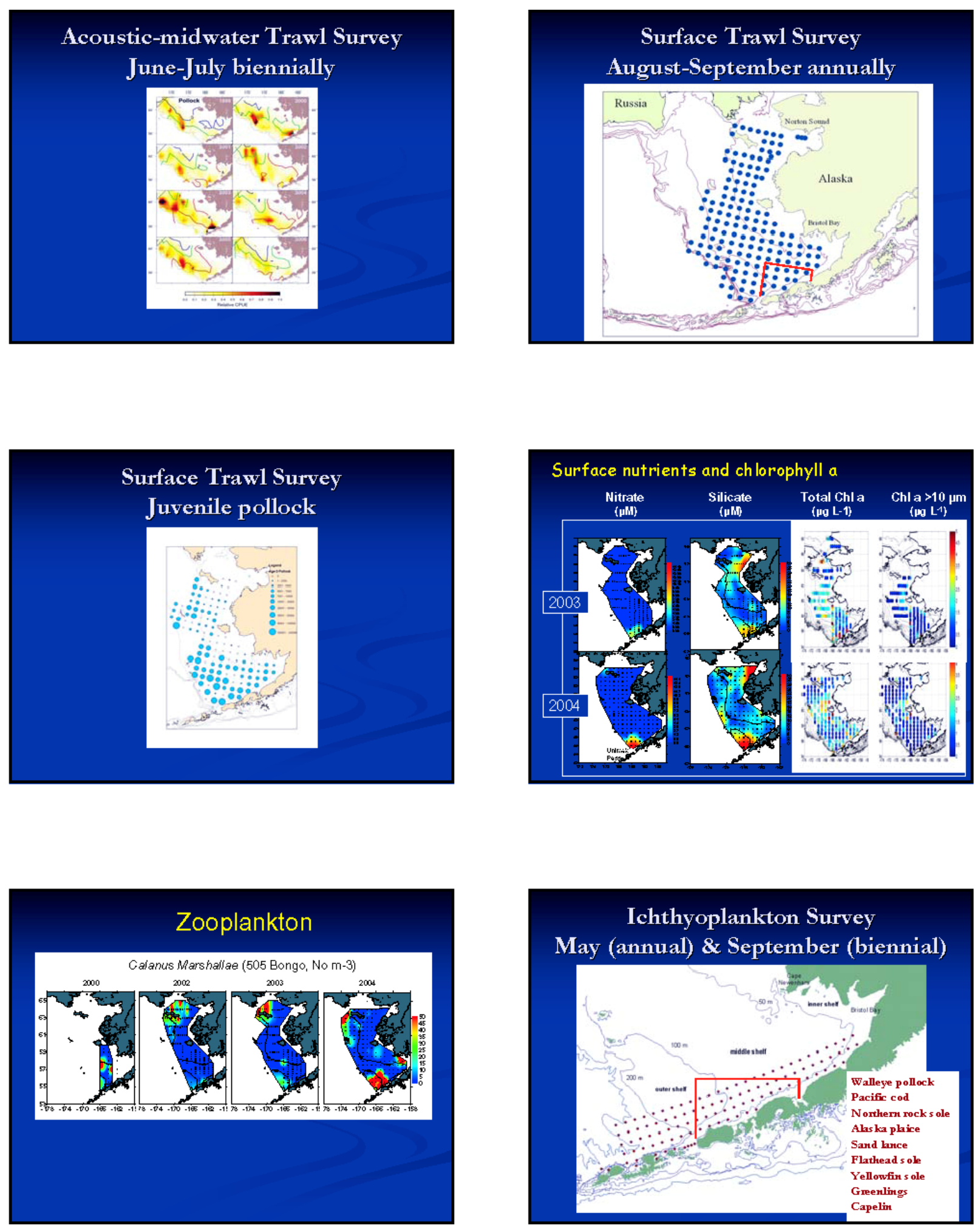

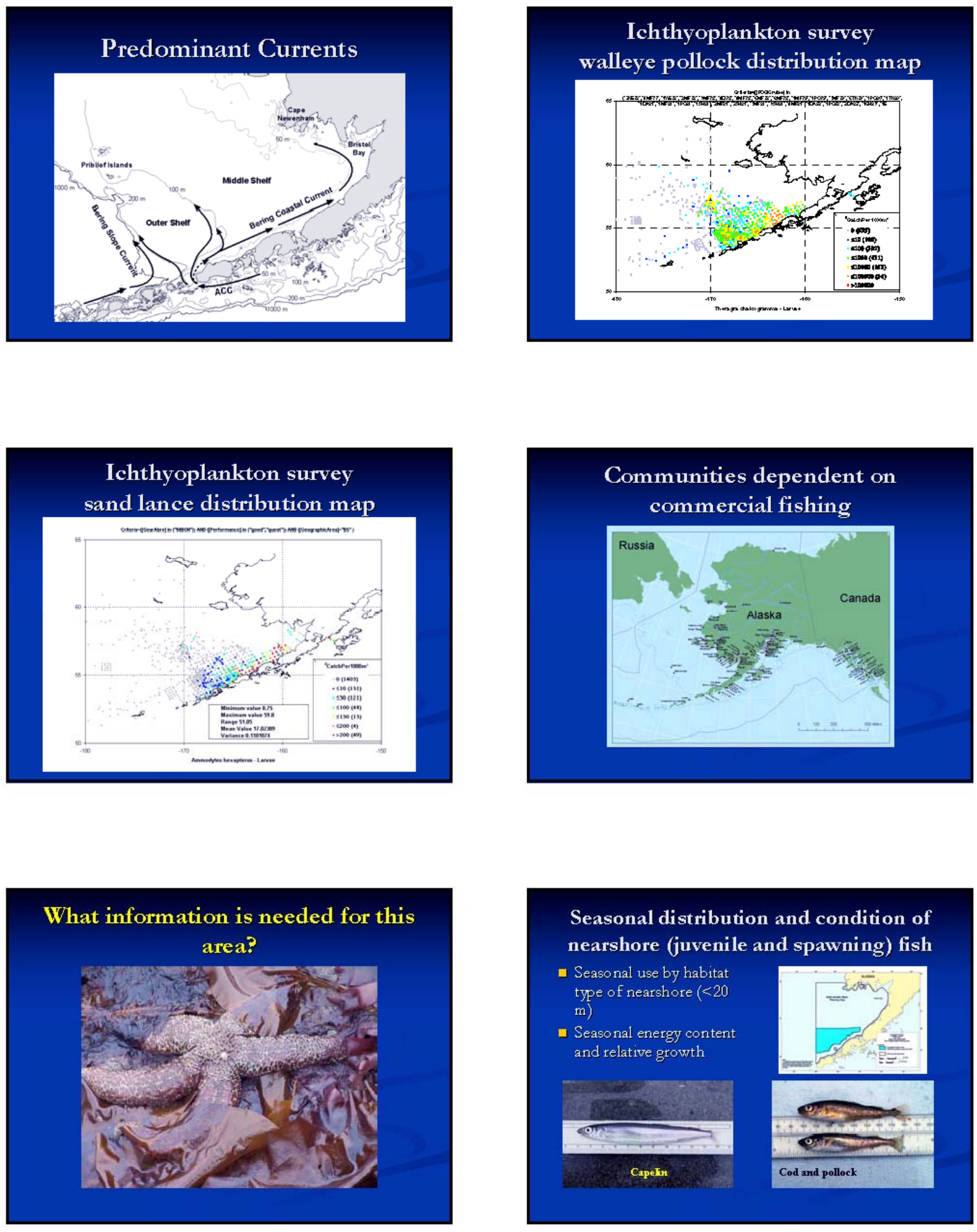


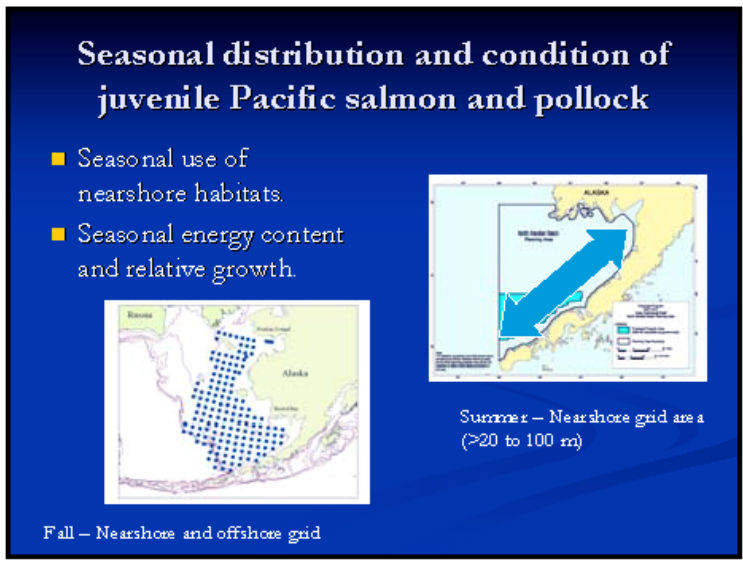

\section{Seasonal fish distribution}

- Track individual adult fish (e.g. cod) from

autonomous, widely-spaced moorings.

- Describe seasonal distributional shifts.
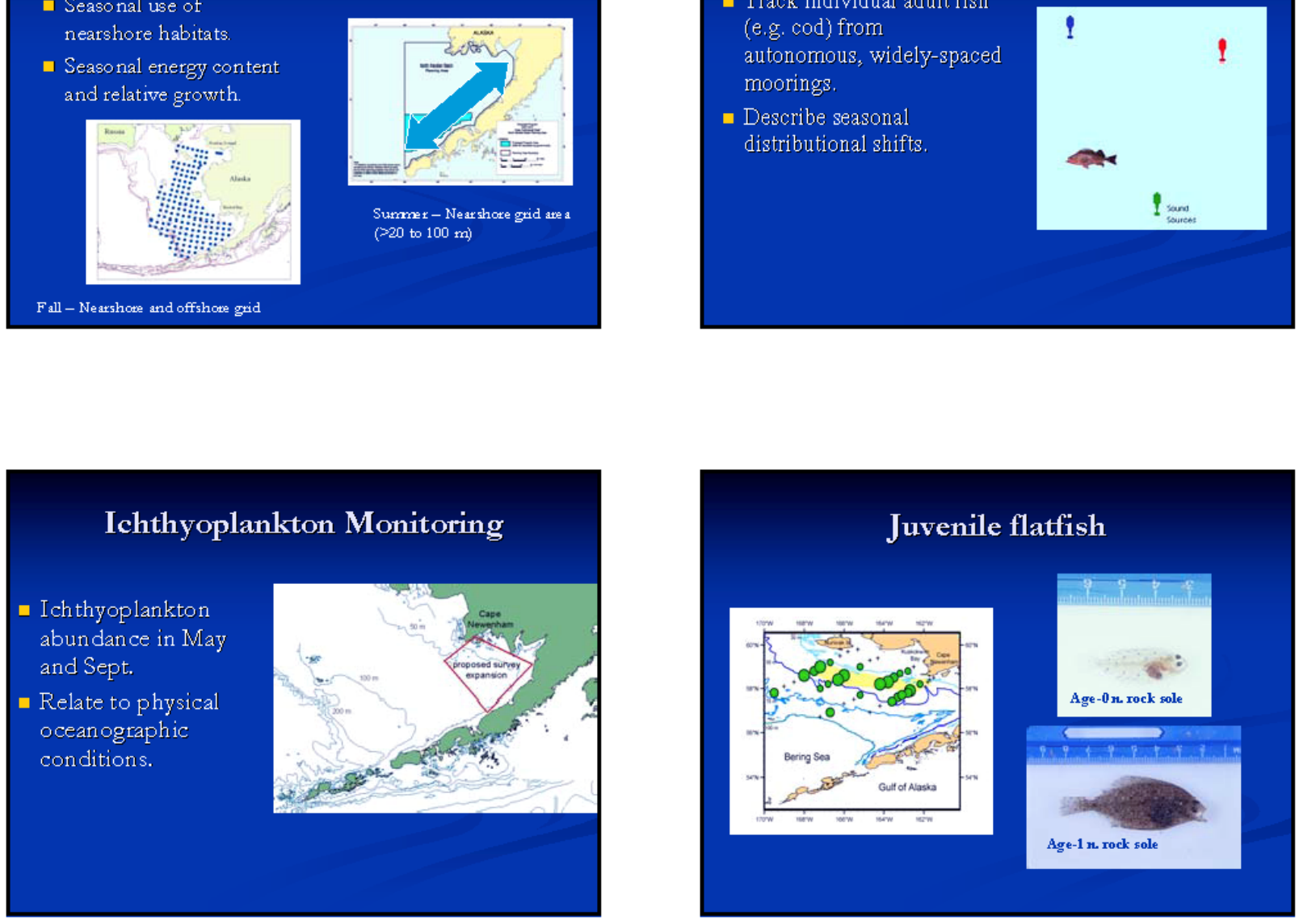

\section{Bering Sea Fish Catalogue}

Build web-based access to extensive NOAA databases (1975-present)

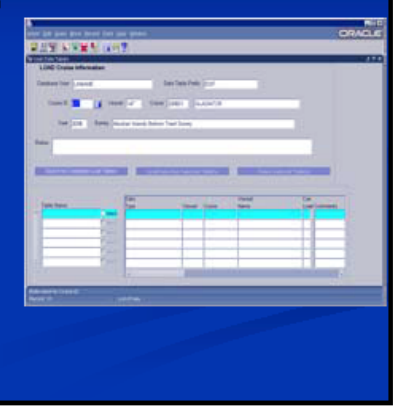

\section{What uncertainties should be} addressed first?

- Nearshore and juvenile fish, including ichthyoplankton

- Seasonal abundance and distribution 


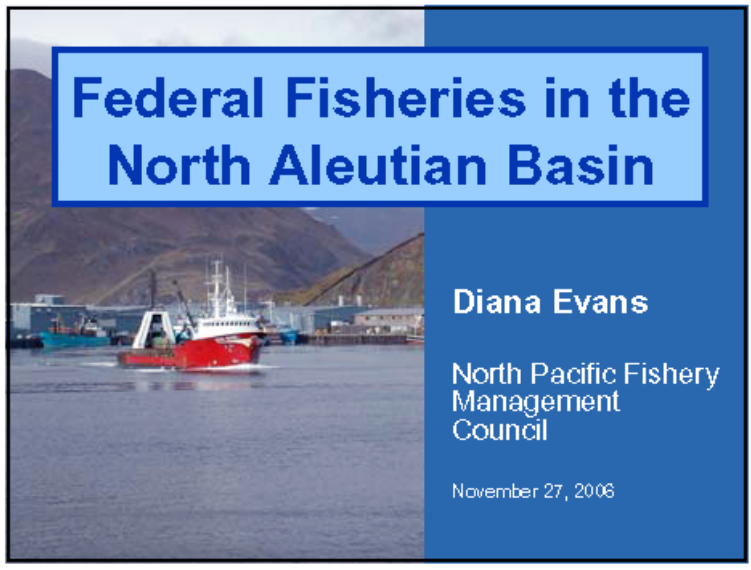

\section{Fishery Management Process}

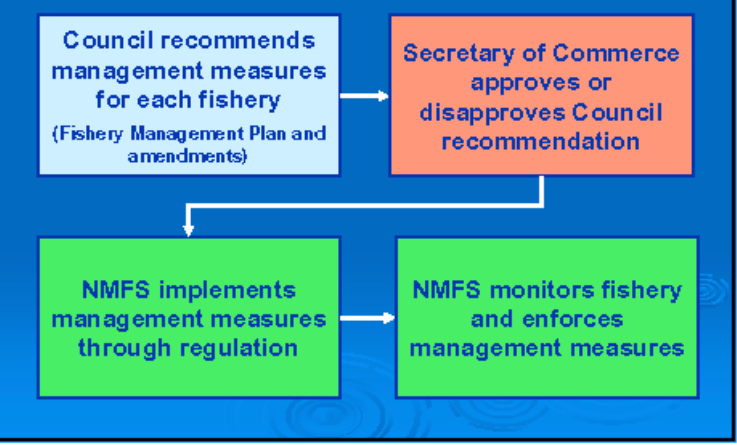

\section{Council membership}

11 voting members

- (1) NMFS RA;

- (3) WA, OR, AK State Fishery Dept heads;

- (5) AK 'at large' seats appointed by AK governor

- (2) WA 'at large' seats appoint by WA governor

> 4 non-voting members (USFWS, USCG PSMFC, Dept of State)

\section{Plan for talk}

$>$ Background

- the Council

- Federal fisheries management

$>$ Fishery distribution within the proposed

Sale 92 area of the North Aleutian Basin

- Groundfish

- Halibut

- Crab

- Scallop

\section{What is the Council?}

Responsibilities under MSA:

Prepare a Fishery Management Plan for each fishery under its authority

Submit amendments to FMPs as necessary

Conduct public hearings to allow all interested persons to be heard regarding FMPs and their implementation

Review stock assessments and harvest specifications

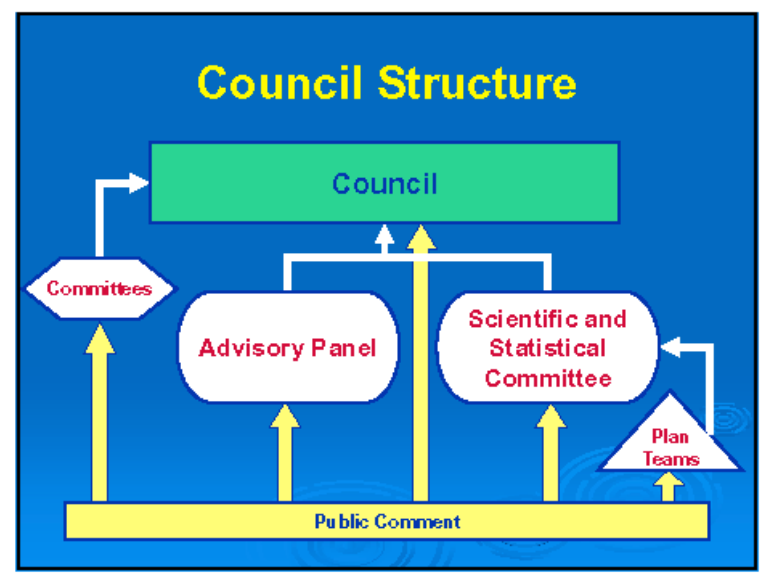




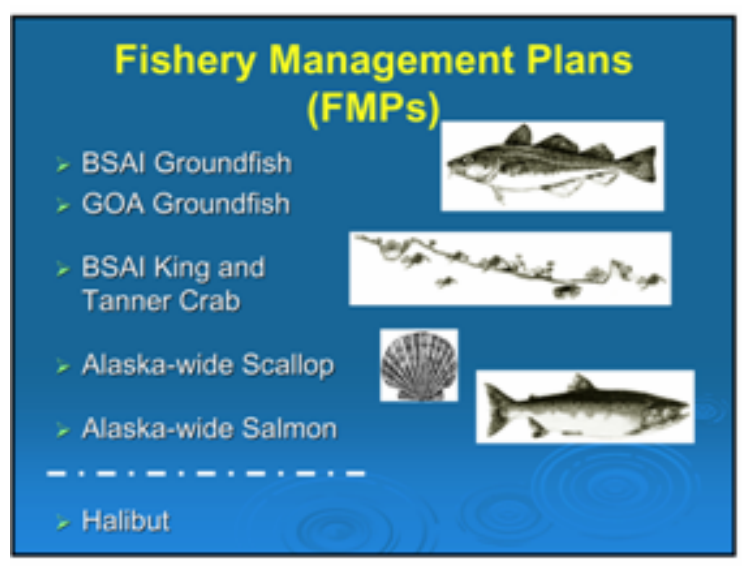

\begin{tabular}{|l|c|c|}
\hline \multicolumn{3}{|c|}{ Setting Harvest Levels } \\
\hline & $\begin{array}{c}\text { Optimum Yield' and } \\
\text { Overfishing Levels }\end{array}$ & $\begin{array}{c}\text { Actual annual } \\
\text { harvest levels }\end{array}$ \\
\hline Groundfish & Council & Council \\
\hline Crab & Council & State of Alaska \\
\hline Scallop & Council & State of Alaska \\
\hline Halibut & $\begin{array}{l}\text { International Pacific } \\
\text { Halibut Commission }\end{array}$ & $\begin{array}{l}\text { International Pacific } \\
\text { Halibut Commission }\end{array}$ \\
\hline 'expressed as a rmoe & \\
\hline
\end{tabular}
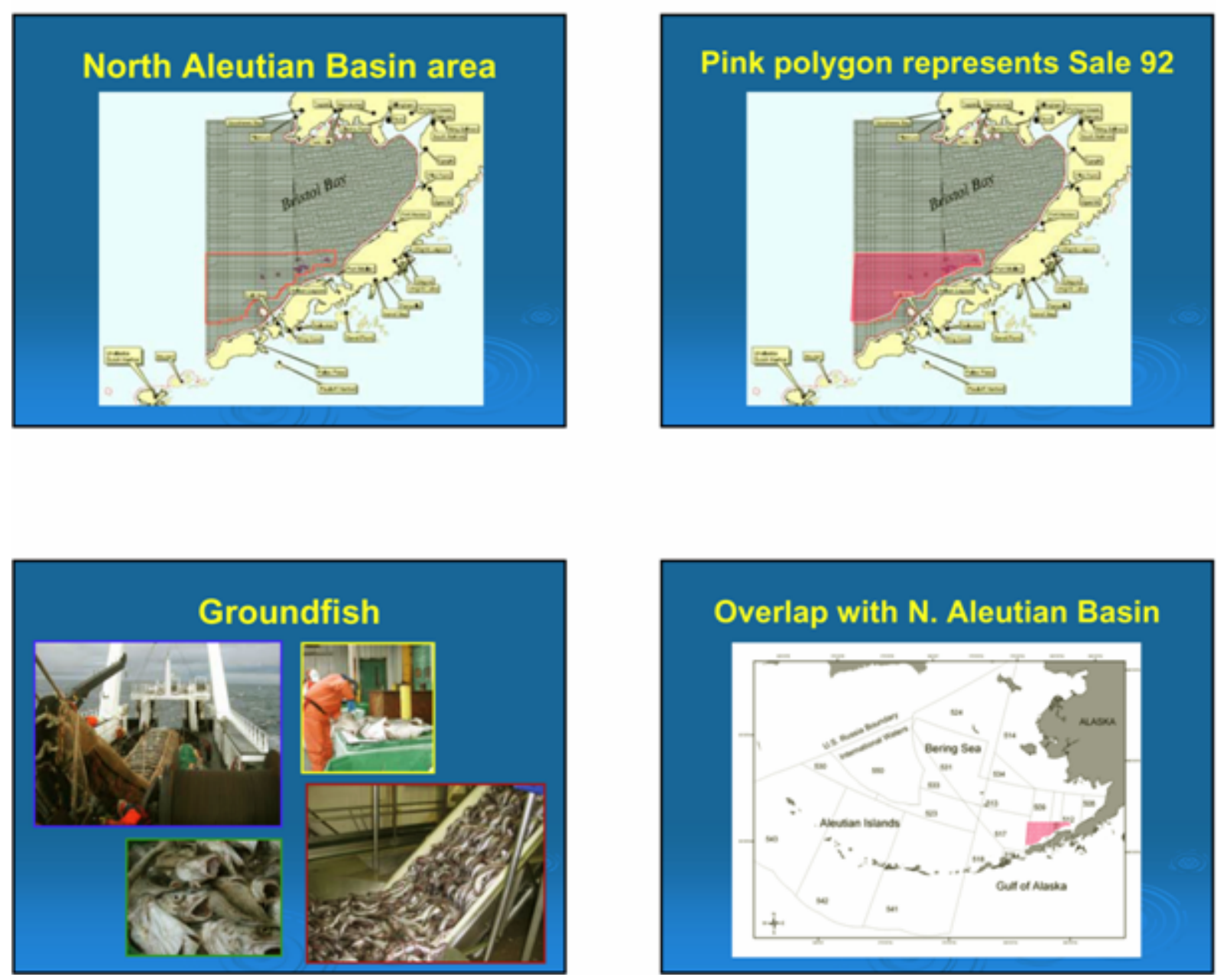


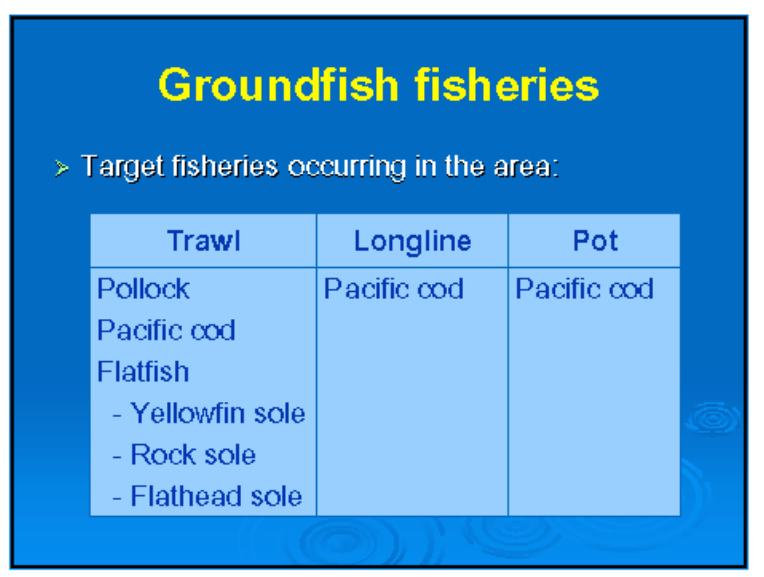

\begin{tabular}{|l|c|c|}
\hline \multicolumn{3}{|c|}{ Fishery Harvest - 2005} \\
\hline & $\begin{array}{c}\text { Harvested in } \\
509,516,512\end{array}$ & $\begin{array}{c}\text { \% of total BSAl } \\
\text { harvest }\end{array}$ \\
\hline Pollock trawl & 317,089 & $21 \%$ \\
\hline Pacific cod traw & 26,028 & $40 \%$ \\
\hline Pacific cod longline & 13,300 & $11 \%$ \\
\hline Pacific cod pot & 4,727 & $28 \%$ \\
\hline Yellowin sole trawl & 6,674 & $7 \%$ \\
\hline Flathead sole traw & 2,292 & $55 \%$ \\
\hline Rock sole trawl & 20,418 & $14 \%$ \\
\hline
\end{tabular}
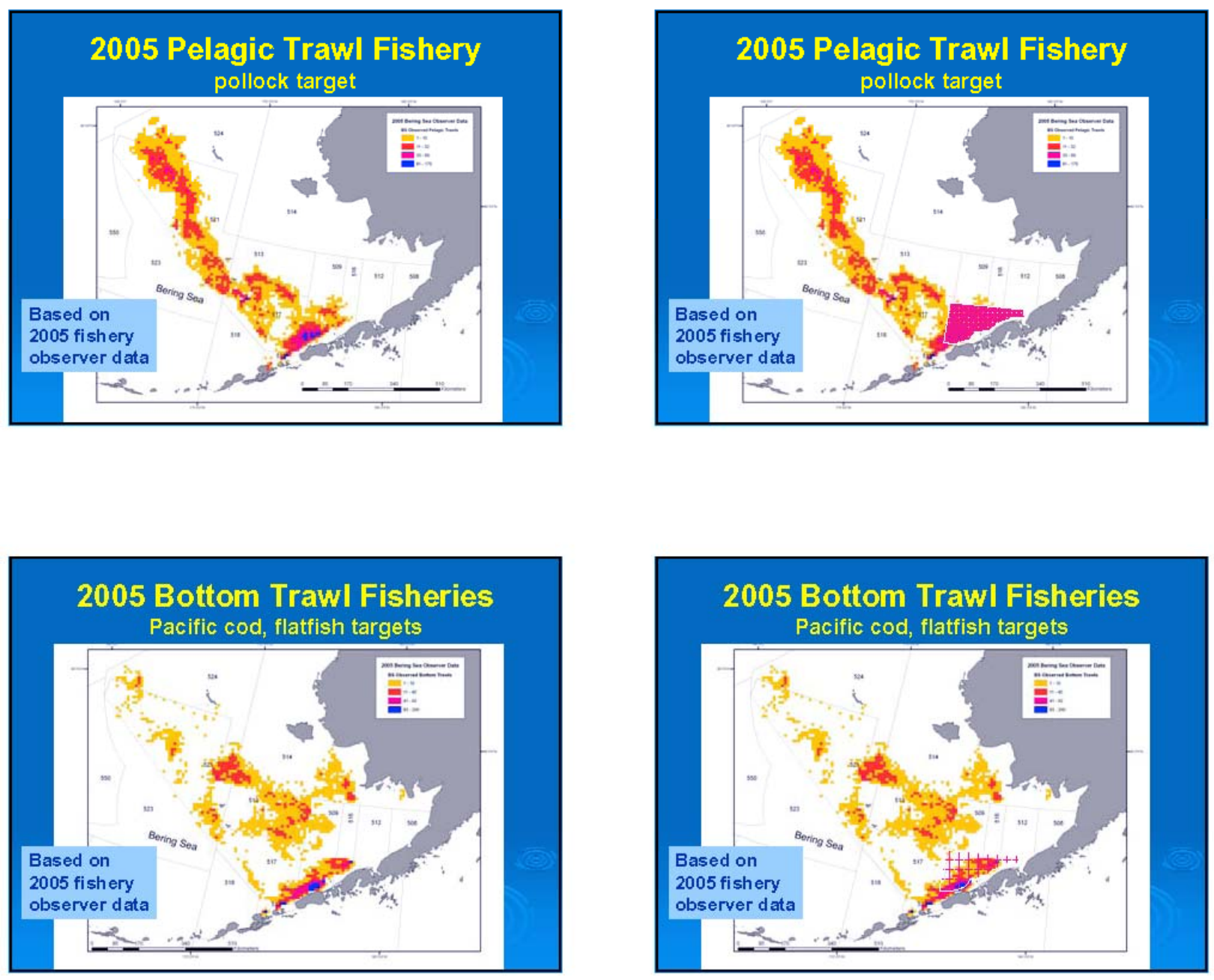

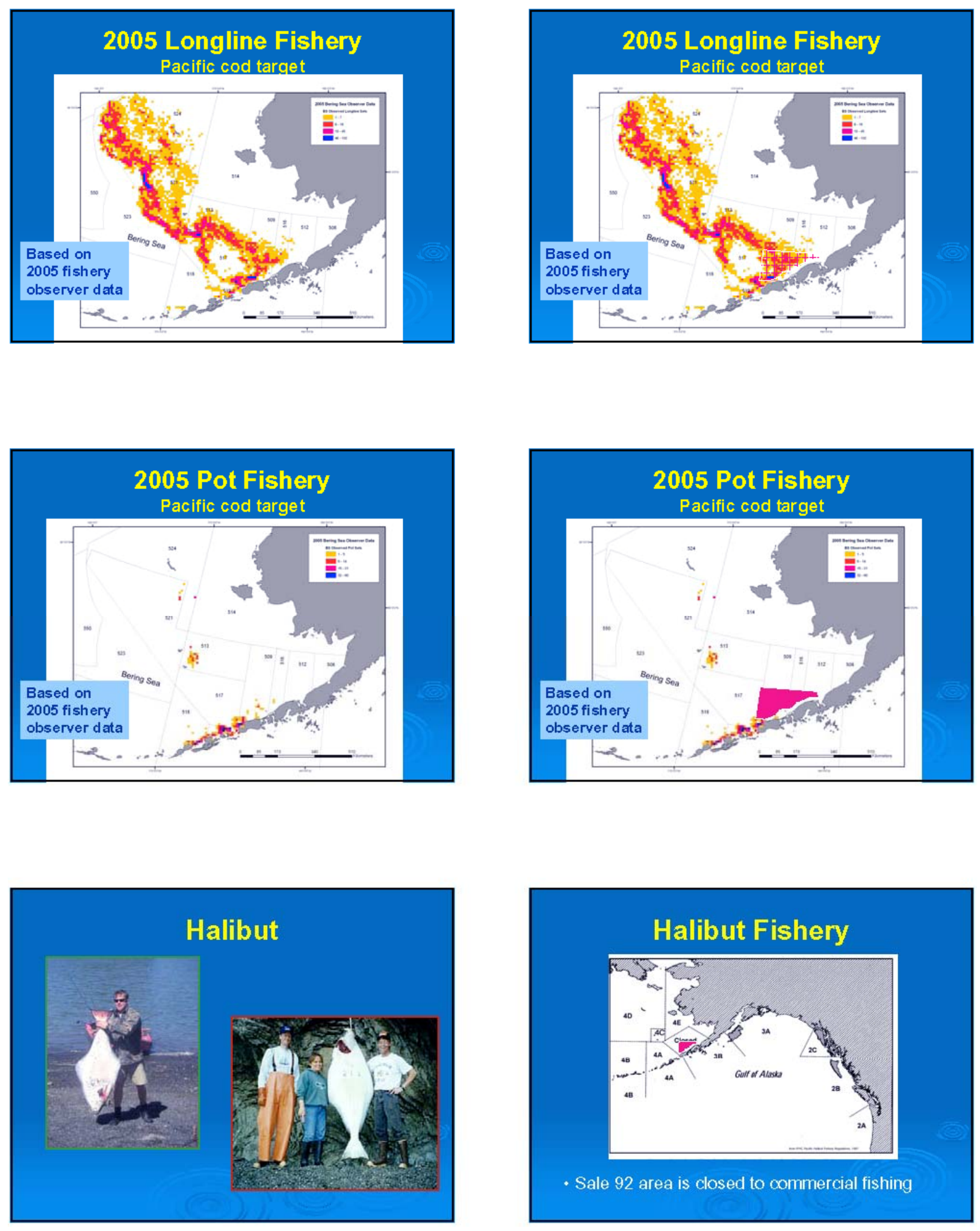

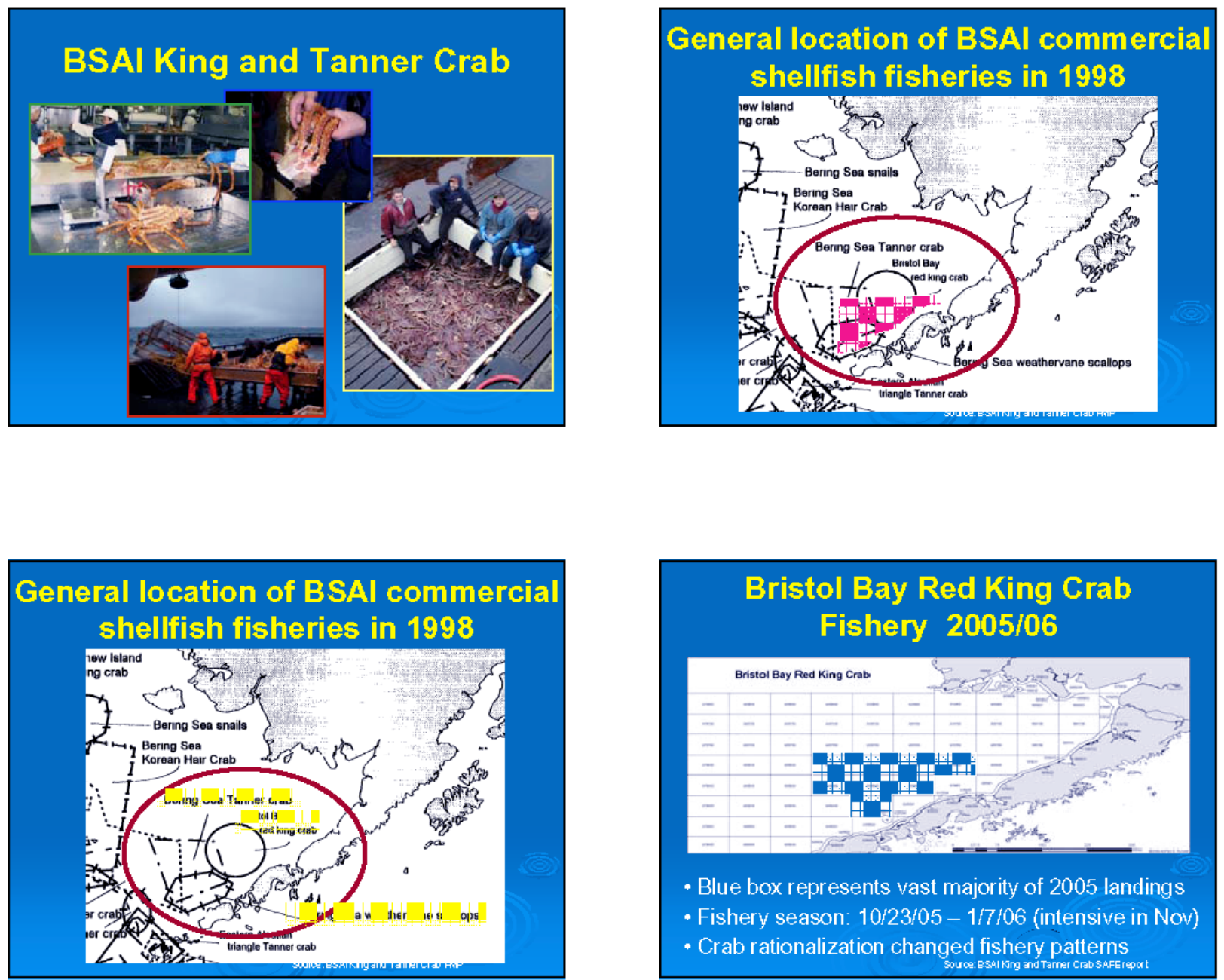

\section{Bristol Bay Red King Crab Fishery 2005/06}

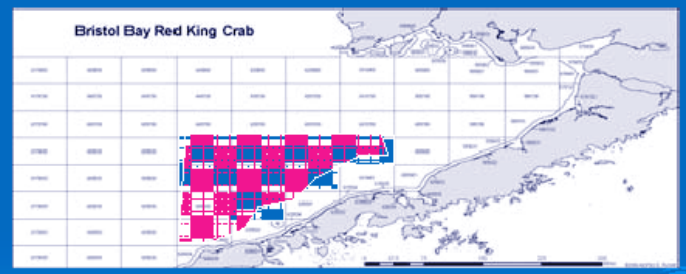

- By week, anywhere from 1-51 vessels participating - 2.5 million crabs harvested, 16.5 million lbs

\section{Bering Sea Tanner crab}

Fishery closed 1997-2004

$>2005-$ no overlap

- Fishery occurred west of the North Aleutian Basin

Early/mid-1990s, some incidental harvest of Tanner crab in BBRKC fishery 

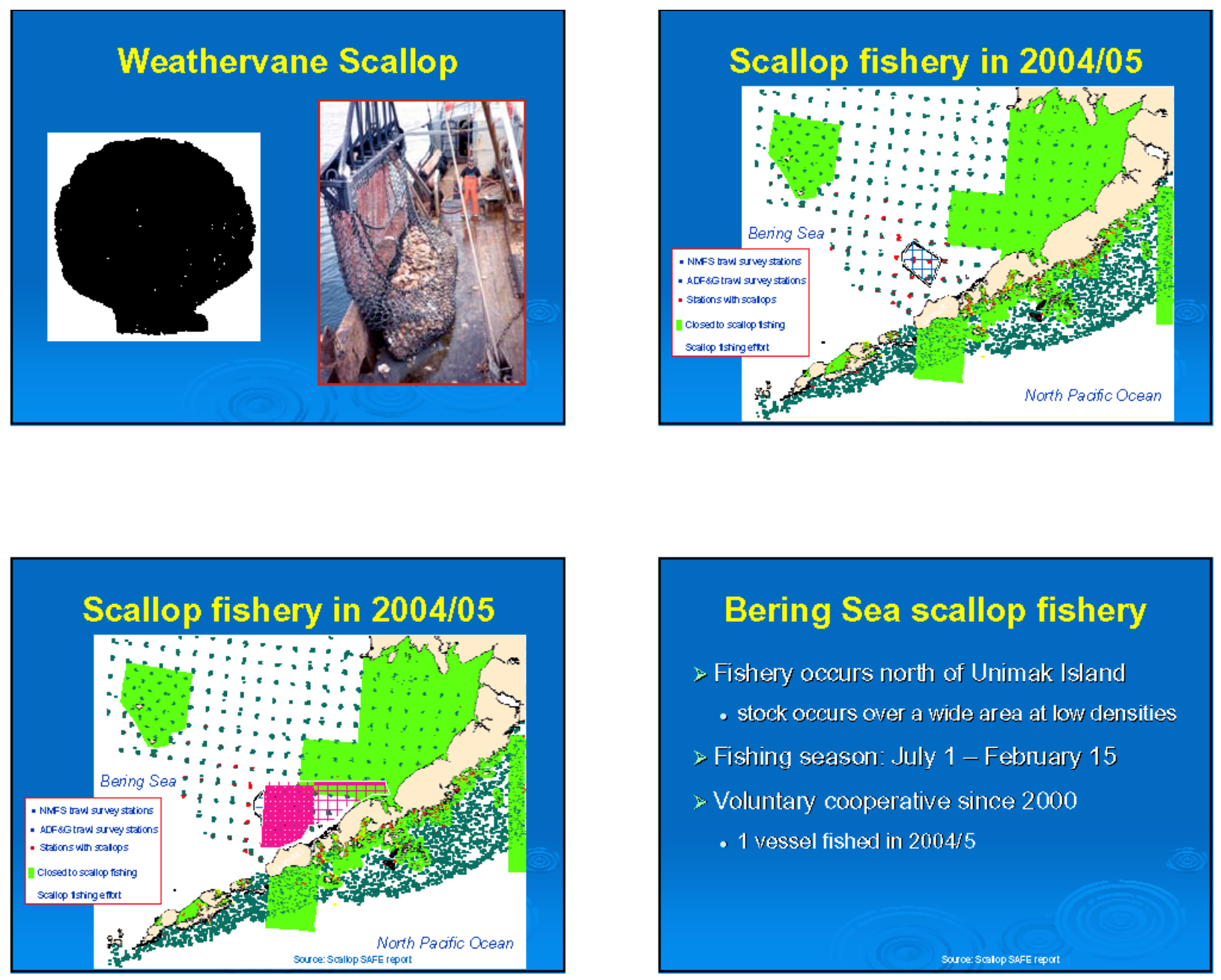

\section{Bering Sea scallop fishery}

$>$ Fishery occurs north of Unimak Island

- stock occurs over a wide area at low densities

> Fistring season: July 1 - Febnuary 15

- Voluntary cooperative since 2000

- 1 vessel fished in $2004 / 5$

\section{Bering Sea Area scallop fishery summary statistics}

\begin{tabular}{|c|c|c|c|c|c|}
\hline Season & $\begin{array}{l}\text { Number } \\
\text { vessels }\end{array}$ & $\begin{array}{c}\text { GHR } \\
\text { ceiling } \\
\text { (bs meat) }\end{array}$ & $\begin{array}{l}\text { Dredge } \\
\text { hours }^{\natural}\end{array}$ & $\begin{array}{l}\text { Catcha } \\
\text { (lbs meat) }\end{array}$ & $\begin{array}{c}\text { Duration of } \\
\text { fishery }\end{array}$ \\
\hline $2000 / 01$ & 3 & 200,000 & 3,355 & 205,520 & \\
\hline $2001 / 02$ & 3 & 200,000 & 3,072 & 140,871 & $7 / 1-11 / 1$ \\
\hline $2002 / 03$ & 2 & 105,000 & 2,038 & 92,240 & $9 / 5-1 / 6$ \\
\hline $2003 / 04$ & 2 & 105,000 & 1,020 & 42,590 & $7 / 1-7 / 18$ \\
\hline $2004 / 05$ & 1 & 105,000 & 275 & 10,050 & $7 / 1-7 / 13$ \\
\hline \multirow{2}{*}{\multicolumn{5}{|c|}{$\begin{array}{l}2005 / 06 \\
\text { aConfidential data released by vessel op erators }\end{array}$}} & \multirow[t]{2}{*}{$12 / 13-1 / 11$} \\
\hline & & & & & \\
\hline & & & & & \\
\hline
\end{tabular}


Potential Impacts of North Aleutian Basin Oil \& Gas Development on Commercial Fisheries:

What Do We Know? What Research is Neded?

Gunnar Knapp

Professor of Economics

Institute of Social and Economic Fesearch

University of Alaska Anchorag

Gunnar.Knapp@uaa.alaska.edu

Prepared for

Minerak Management Services

"North Aleutian Basin Information Status and Research Planning Meeting" November 28 - December 1,2006 Anchorage, Alaska
The fisheries which might be affected by North Aleutian Basin oil and gas development a re diverse and complex.

- Multiple fish species

- Multiple types of fisheries (commercial, sport, subsistence)

- Multiple types of participants (families to large corporations)

- Multiple types of fishing vessels (small to very large)

- Multiple management agencies (state, federal, and international)

- The fisheries occur over a wide geographic area

- The fisheries have economic impacts and importance over far wider geographic region extending throughout Alaska and the Pacific Northwest.
Important characteristics of commercial fisheries which might be affected by North Aleutian Basin oil and gas development

- These fisheries arevery economically significant, with annual wholesale value of close to half a billion dollars

- Catches, production, prices and value vary widely from year to year

- The fisheries are highly sea sonal

- Commercial fishing and processing is overwhelmingly the most important private-sector industry of the region.

- In the small, predominantly Native villages, salmon fishing is an important source of income and jobs

- Several towns have major fish processing industries and support industries

The economic benefits and impacts of the industry extend far beyond the region:

- A large share of the fishermen are from outside the region

- A very large share of the processing work force is non-resident

- Most of the processing industry is headquartered in Seattle.

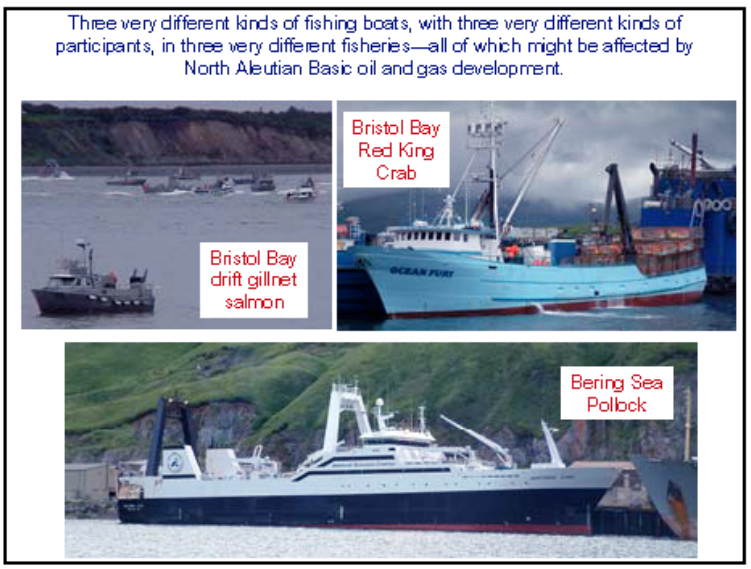

The Purpose of this Meeting (from the meeting announcement)

"... To review the status of available scienfific information and advise MMS of additional information that may be needed for a regional envronmental impact statement about oil and gas leasing"

\begin{tabular}{|c|c|}
\hline $\begin{array}{l}\text { How the meetingagenda describes what tis } \\
\text { meeting will ty b do }\end{array}$ & $\begin{array}{l}\text { Gorresponding questions fat l address in tis } \\
\text { presentation }\end{array}$ \\
\hline 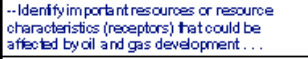 & $\begin{array}{l}\text { 1. What are major isheries that might be affected } \\
\text { by North Aleutian Basin (NAB) cil \& gas } \\
\text { deteropmert? }\end{array}$ \\
\hline 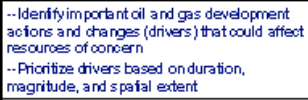 & $\begin{array}{l}\text { 2. How might NAB oil and gas development affect } \\
\text { tere fisteries? }\end{array}$ \\
\hline 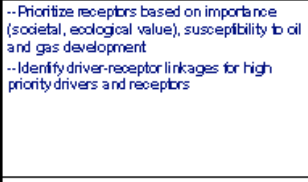 & 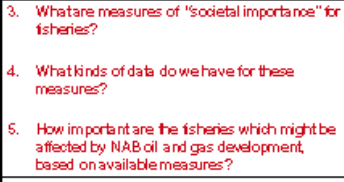 \\
\hline $\begin{array}{l}\text {--1denify intormation nesds for pricity driver. } \\
\text { receptr lirkages } \\
\text {-- Pricritize information needs }\end{array}$ & $\begin{array}{l}\text { 6. Whatare te mostimportant research needs tor } \\
\text { undestanding potenial impacts of WAB ail and } \\
\text { gas devedopment on fisteries? }\end{array}$ \\
\hline
\end{tabular}


1. What are major fisheries that might be affected by North Aleutian Basin (NAB) oil \& gas development?

Potentially affected fisheries include-but are not necessarily limited to:

\begin{tabular}{|c|c|c|c|}
\hline Maragsment & Species goup & Species & Fistery \\
\hline 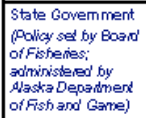 & Salmon & \begin{tabular}{|l|} 
Sockere salmon \\
Crinock salmon
\end{tabular} & 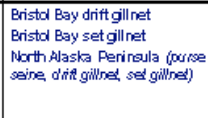 \\
\hline \multirow{6}{*}{ 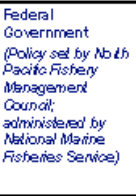 } & \multirow[t]{5}{*}{ Groundfisti } & Pollock & BSAI Pollock trayt \\
\hline & & Pacific Cod & $\begin{array}{l}\text { BSAI Pacific cod trawl } \\
\text { BSAI Pacific cod longline } \\
\text { BSAI Pacific cod pot } \\
\end{array}$ \\
\hline & & \begin{tabular}{|l} 
Yellowins \\
Yole
\end{tabular} & BSAI Yellowfin sole trawt \\
\hline & & \begin{tabular}{|l|} 
Hathead sole \\
\end{tabular} & BSAl hattread sole traw \\
\hline & & \begin{tabular}{|l|} 
Fock sole \\
\end{tabular} & BSAl Rock sole trwl \\
\hline & Shellfish & Withervane Scallop & Bering Sea Scallop \\
\hline $\begin{array}{l}\text { Federal goverment } \\
\text { (delegated to State) }\end{array}$ & Grab & Ried KingGrab & Bristal Bay Red King Grab \\
\hline
\end{tabular}

Potentially affected fisheries of significant economic importance are not limited to commercial fisheries. Both the guided sport fishing industry

and subsistence fisheries are of significant economic importance.
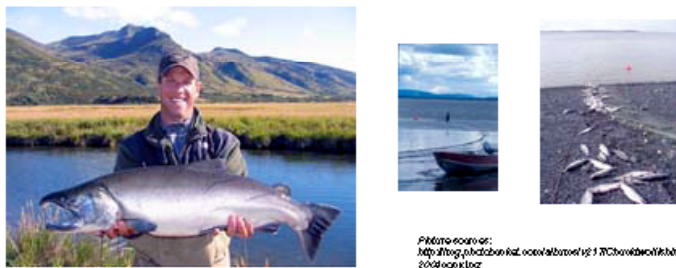

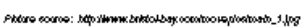

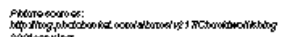

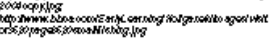

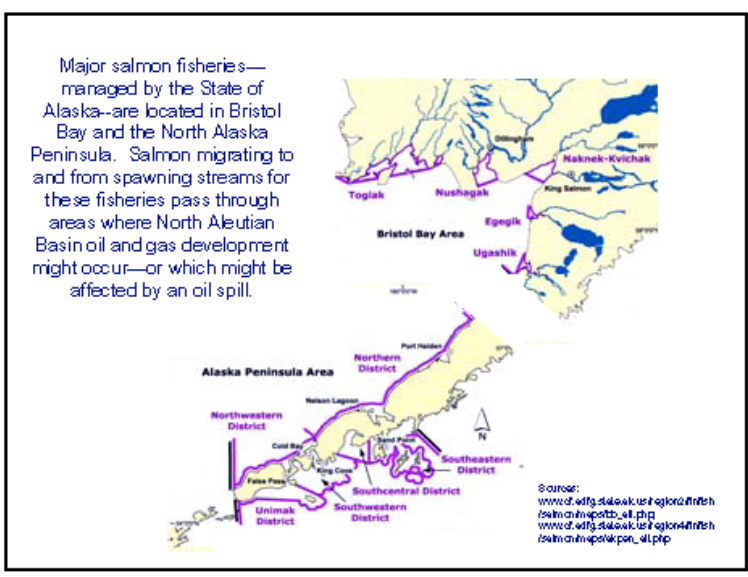

2. How might North Aleutian Basin oil and gas devebpment affect fisheries?

Probably the most significant effects would result fromoil spills.

Effects on
fishery
resources
Fisheries
closures to
protect safety

Oil spills are not the only way in which $N A B$ oil and gas development might affect fisheries. There are a variety of other potential impacts which are probably more likely to occur, but smaller in scale - and relatively easier to

$$
\text { assess. }
$$

\begin{tabular}{|l|l|}
\hline Examples of potential drivers & \multicolumn{1}{|c|}{ Examples of potential impacts } \\
\hline $\begin{array}{l}\text { Infrastructure development } \\
\text { (diil nigs, oil piatfoms, } \\
\text { pipelines, roads, ports, } \\
\text { airstrips, energy) }\end{array}$ & $\begin{array}{l}\text { Navigational hazands } \\
\text { Areas closed to fishing due to drilling rigs or } \\
\text { subsea pipelines } \\
\text { Reduction in trans portation oosts and energy } \\
\text { costs for fishemnen and processors }\end{array}$ \\
\hline Marine traffic & $\begin{array}{l}\text { Navigational hazands } \\
\text { Areas closed to fishing }\end{array}$ \\
\hline Population growth & Increased demand for sport fishery resources \\
\hline Tax revenues & Improvements in fisheries infrastructure \\
\hline
\end{tabular}




\begin{tabular}{|c|c|}
\hline Concept & Measure \\
\hline \multirow{3}{*}{ Gross revenues } & Ex-wessel value \\
\hline & Processing valueadded \\
\hline & Support-industry income \\
\hline \multirow{3}{*}{$\begin{array}{l}\text { Net economic benefit } \\
\text { (revenue - costs) }\end{array}$} & Hanvester net income \\
\hline & Processor profit \\
\hline & Support industry profit \\
\hline \multirow{3}{*}{$\begin{array}{l}\text { Participation } \\
\text { (number of persons working) }\end{array}$} & Haruesting \\
\hline & Processing \\
\hline & Support industries \\
\hline \multirow{3}{*}{$\begin{array}{l}\text { Emp byment } \\
\text { (mar-months or man-years worked) }\end{array}$} & Hanesting emp byment \\
\hline & Processing emp byment \\
\hline & Support industries \\
\hline Tax revenues & Tax revenue \\
\hline
\end{tabular}

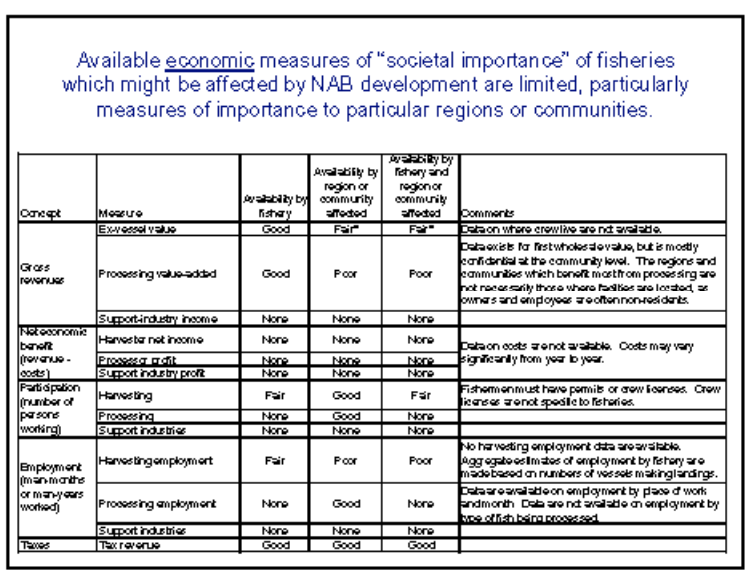

5. How important are the fisheries which might be affected by NAB oil and gas development, based on available measures?

The simplest measures of economic importance, and the one for which data are mosteasily avallable, are ex-vessel and whoksale value. As a very rough rule of thumb, these fishenes have a combined annual ex-vessel value of about $\$ 200$ 作 significantly buer or higher in some years.

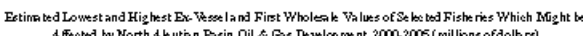

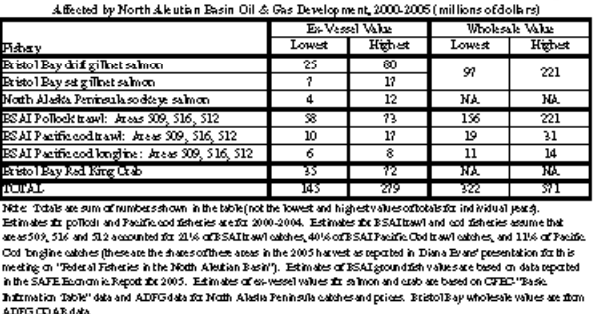

The Bristol Bay Salmon Fishery

World's largest sockeye salmon fishery

+ 1980-2003 average annual catches of 20 million sockeve salmon

- 1980-2003 average annual catch value of $\$ 105$ million

- Historically $20-40 \%$ of total

value of Alaska salmon fisheries

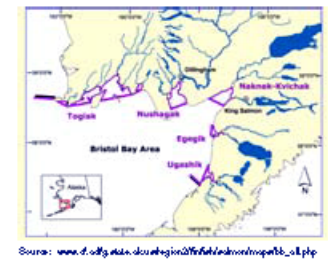

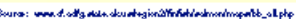

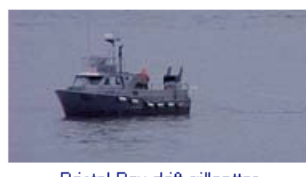

Selected measures of the economic importance of the Bristol Bay salmon fishery

Bristol Bay Salmon Fishery: Selected Economic Measures

\begin{tabular}{|c|c|c|c|c|}
\hline Mimasure & Fishery & 2003 & 2004 & 2005 \\
\hline \multirow{3}{*}{\begin{tabular}{|l|}
$\mid$\begin{tabular}{|l} 
Ex-vessel \\
value
\end{tabular} \\
\end{tabular}} & or ifit gillnet fishery & $\$ 37,099$ & $\$ 65,670$ & $\$ 80,502$ \\
\hline & Setgillnet fistery & $\$ 10,417$ & $\$ 11,664$ & $\$ 17,399$ \\
\hline & Total & $\$ 48,416$ & $\$ 7,333$ & $\$ 97,951$ \\
\hline \multicolumn{2}{|c|}{ First wholesale value $(\$ 000)$} & $\$ 111923$ & $\$ 178,758$ & $\$ 221,679$ \\
\hline \multirow{3}{*}{\begin{tabular}{|l}
$\begin{array}{l}\text { Number of } \\
\text { permits } \\
\text { fished }\end{array}$ \\
\end{tabular}} & Drift gillnet fishery & 1424 & 1411 & 1447 \\
\hline & Setgillnet fistery & 761 & 795 & 829 \\
\hline & Total & 2185 & 2206 & 2276 \\
\hline \multicolumn{2}{|c|}{ Estimated hanuesting participation } & 6555 & 6618 & 6828 \\
\hline \multicolumn{2}{|c|}{ Estimated hanuesting FTE employment } & 546 & 552 & 569 \\
\hline \multicolumn{5}{|c|}{ 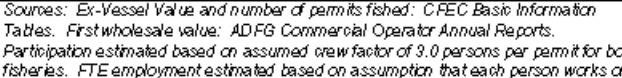 } \\
\hline
\end{tabular}

4. What kinds of data do we have for measures of "societal importance" of fisheries?

Available data for potential measures of "societal importance" or Available data differ for different fisheries depending on who manages Them and how they are managed.

fisermen and processing workers come from other regions than their impotance to particular regions or importance of

\section{ions}

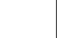

Bristol Bay drift gillnetter 


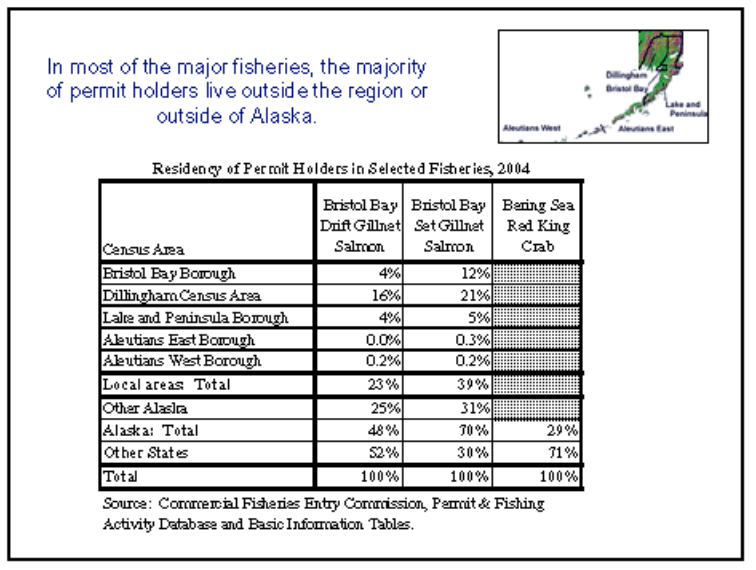

6. What are the most important research needs for understanding potential impacts of $\mathrm{NAB}$ oil and gas development on fisheries?

To estimate potential oil-spill related effects, we need to tyy to answer the following questions. The answer to each question depends on the answers to all the previous questions. The level of uncertainty increases with each question.

\begin{tabular}{|l|l|}
\hline $\begin{array}{l}\text { Devebpment } \\
\text { scenanis }\end{array}$ & $\begin{array}{l}\text { Where, when and how might oil exp bration and development } \\
\text { occur? }\end{array}$ \\
\hline Potential for spills & $\begin{array}{l}\text { What is the probability of oil spills, by spill magnitude and time of } \\
\text { year? }\end{array}$ \\
\hline Spill trajectony & $\begin{array}{l}\text { What is the probability that spilled oil would reach different } \\
\text { bcations? }\end{array}$ \\
\hline Fisheries closures & $\begin{array}{l}\text { What is the probability that oil spills would result in fisheries } \\
\text { closures? }\end{array}$ \\
\hline $\begin{array}{l}\text { Spill effects on } \\
\text { resources }\end{array}$ & $\begin{array}{l}\text { What is the probability of long-term effects on fisheries } \\
\text { resoures? }\end{array}$ \\
\hline $\begin{array}{l}\text { Effect on catches } \\
\text { and prices }\end{array}$ & How might oil spills affect catches and prices? \\
\hline $\begin{array}{l}\text { Aggregate economis } \\
\text { effects }\end{array}$ & $\begin{array}{l}\text { What would be the aggregate economic effects of changes in } \\
\text { catches and prices? }\end{array}$ \\
\hline $\begin{array}{l}\text { Distribution of } \\
\text { economic effects }\end{array}$ & $\begin{array}{l}\text { How would these effects be distributed by community and } \\
\text { region? What would be their reative significance? }\end{array}$ \\
\hline
\end{tabular}

Here is an initial guess at our ability to address these questions through reseanch. For each question, I assume that we know the answers to the previous question.

\begin{tabular}{|c|c|c|c|c|}
\hline \multirow[b]{2}{*}{ Question } & \multicolumn{2}{|c|}{$\begin{array}{l}\text { Our ability b make specific } \\
\text { predicfions }\end{array}$} & \multicolumn{2}{|c|}{$\begin{array}{l}\text { Our ability to make } \\
\text { probatilisic projections }\end{array}$} \\
\hline & Gurrenty & $\begin{array}{l}\text { With furter } \\
\text { research }\end{array}$ & Qumently & $\begin{array}{l}\text { With istther } \\
\text { research }\end{array}$ \\
\hline Development soenario & L & M & $\mathrm{L}$ & $\mathrm{H}$ \\
\hline Potenfial for spills & $\mathrm{L}$ & L & $\mathrm{L}$ & $m$ \\
\hline Spill trajectory & L & M & L & M \\
\hline Fisheries dosures & L & $\mathrm{H}$ & $\mathrm{L}$ & $\mathrm{H}$ \\
\hline Spill effect on resources & L & $\mathrm{L}$ & $\mathrm{L}$ & L \\
\hline $\begin{array}{l}\text { Effect oncathes and } \\
\text { prices }\end{array}$ & L & M & L & M \\
\hline $\begin{array}{l}\text { Aggegate exonomic } \\
\text { effects }\end{array}$ & L & M & L & $\mathrm{H}$ \\
\hline $\begin{array}{l}\begin{array}{l}\text { Distibution of economic } \\
\text { effects }\end{array} \\
\text {. }\end{array}$ & L & L & L & $M$ \\
\hline
\end{tabular}

Given the uncertainty as sociated with the previous questions, any estimates of the potential oilspill related economic effects of NAB oil and gas devebpment on fisheries will be highty uncertain. 


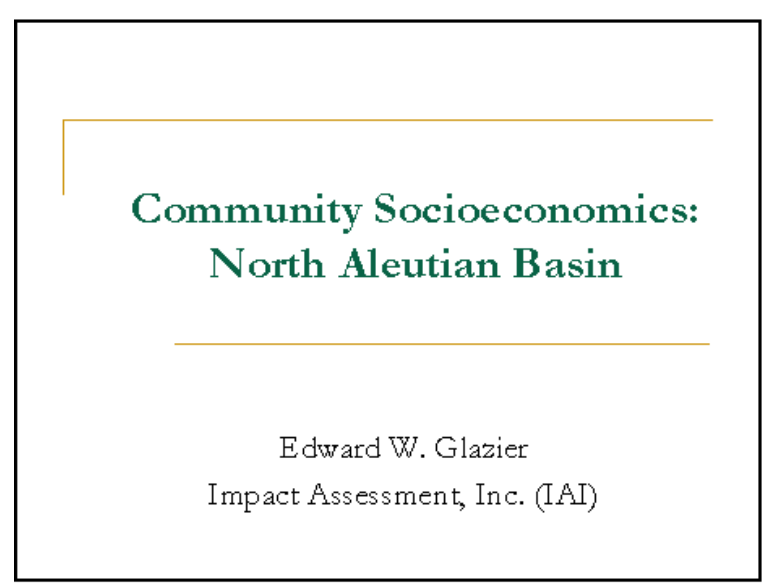

- IAI's early work in the NAB, now 25 years ago, included a 20 year forecast of socioeconomic conditions in the absence of OCS development (see MMS TR-75, subsequently published as $A$ Systems Approach to Social Impact Assesstrent, 1985, Boulder: Wlestview Press)

- The work was intended as baseline against which development scenarios \& OCS-related socioeconomic change could be assessed; forecasts were based on systematic ethnographic work in communities in AEB \& points west

- Similar work was undertaken by IAI in Bristol Bay (see MMS TR-103) \& other areas potentially affected by prospective OCS industry activity (see MMS TR- $92,93,103,126,128,139,140$ )

- A systems modeling approach was used to assess relationships between social structural aspects of the communities and agents or forces of change

- The approach was applied along many dimensions: ecology, demography, economics, socio-politics, social netwo rks, education, health care, and religion

- It was attentive to factors such as econom ic stratification, the effects of external revenue on subsistence practices, and intra-regional variation in effects of involvement in commercial fisheries
- The intent of this presentation is to discuss previous MMS socioeconomic research conducted in the NAB, and a theoretical orientation for conducting such work in advance of prospective future OCS development in the region

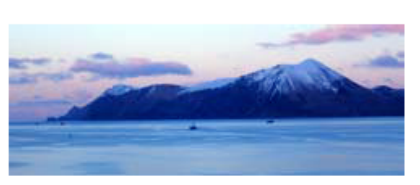

- The research was organized to enable assessment of long-term social change with/without OCS devel.

- Three components were involved: (1) OCS development assumptions/scenarios based on industry needs \& interests, (2) examination \& description of baseline social, cultural, and economic conditions against which OCSrelated changes could be assessed while controlling for other sources of change, and (3) evaluation of potential socioeconom ic effects of OCS develop ment at state, regional \& local levels of analysis
- ANCSA was relatively new and a new(er) economic orderwas developing, commercial fisheries were growing and limited entry fisheries were being introduced; technology was improving the efficiency of pursuit of natural resources

- The dominant source of change was projected to be growth of commercial fisheries \& closer integration of local/indigenous society with more formalized systems of social and political interaction

- This led to forecasts (working hypotheses) that then-current trends of social change would extend into 2002 (even in the absence of OCS development) 
- Select 1982 Hypotheses about NAB Communities:

- Commercial salmon resources would increasingly constitute an important basis of social \& economic change

- Growth of non-indigenous populations would be less significant than other projections were indicating, due in part to the effects of ANCSA and limited entry fisheries

- Increased income \& predominance of the cash economy were seen as likely, but class dichotomization would occur where involvement in comm. fisheries mixed

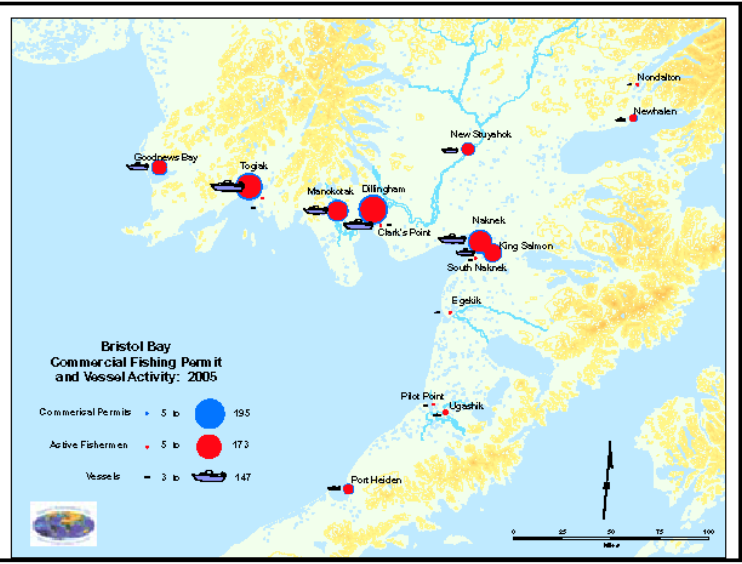

In short, there was emphasis on probable responses to exogenous social \& economic sources of change, \& prediction: integration of traditional/indigenous and capitalist/American-Alaskan societies inevitable

- While some of the hypotheses can now be observed as valid, there is much depth to the story, and a T-2 round of detailed ethnographic work would aid in adequately assessing social change in the region since 1982

- This would be highly instructive given ongoing potential for OCS development \& associated introduction of new agents $\&$ forces of change in this unique region of Alaska

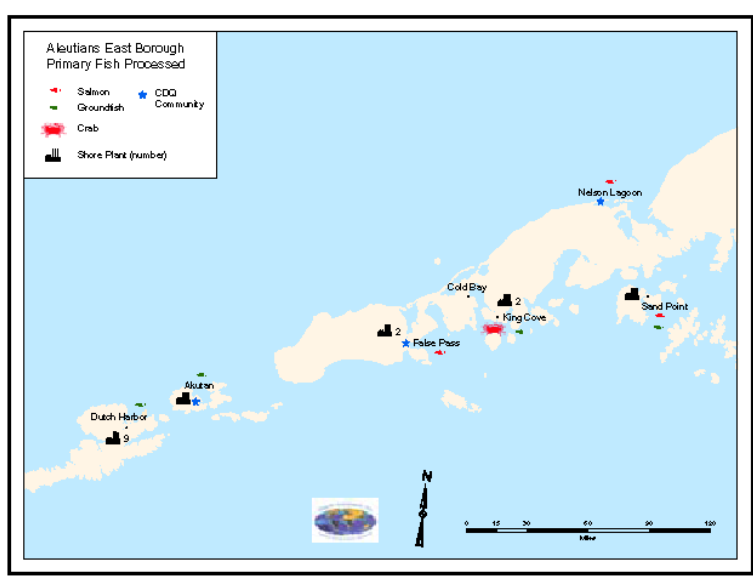

- Increased correlation between income, economic wealth, and political power would be likely

- Social \& economic interaction and political structures in indigenous communities would become more formalized

- Traditional means of subsistence would decline given increasing availability of imported goods

- Adoption of "mainstream" material \& social values would accelerate at the expense of traditional orientations
- Given lessons that have been learned since 1982, future analysis is likely to indicate that traditional Unangan, Alutiig ( \& other Alaska Native) values \& lifeways being enacted with more resilience than was hypothesized

- Actually, the authors did recognize the complexity of social change \& the probability that indigenous residents would retain individual and collective agency (p. ix):

"In spite of the adoption of western values there will be a reversal of trends toward the amalgamation of ethnic identities and a renewal of the strength of [indigenous] ethnic identity. ." 
Indeed, it is possible to accommodate exogenous forces \& factors of change without fully adopting them or sacrificing identity, and many would argue that Unangan and Alutiiq identity are most durable. In fact, indigenous societies have persisted for millenia in Alaska despite a range of challenging factors

- This is highly significant in this context as it is clearly possible for Alaska Natives to nurture identity \& associated lifeways while accommodating, articulating with, or otherwise responding to external forces of change

- Cash and capital are now clearly seen as enabling subsistenceoriented lifeways and associated cultural practices. These aspects of life are not mutually exclusive.
- But one should not infer that these differing ways of life are typically compatible or that attending to traditional lifeways is easy given the pressures of modern societies

= In fact, a conundrum is often generated. That is, cash is required in the modern context, but in the absence of opportunity it is not easily acquired, particularly if one highly values subsistence practices $\&$ associated traditional-cultural lifeways, as these unavoidably require time and energy that cannot be given to capitalist ideals

- As such, forms of economic opportunity that readily enable rather than obviate Alaska Native cultural traditions and practices are typically highly desirable to the practitioners

= Understanding the aforementioned conundrum and indigenous interests, and the way these have played out over time in the $\mathrm{NAB}$ are critically important dimensions of social analysis to be considered in advance of potential OCS development or other source of planned change in the region

- Particularly important given large $\%$ of Alaska Natives living in region, local importance of comm. fisheries, extensive Outside participation in comm. fisheries, few employment alternatives, existing socioeconomic conditions in many communities
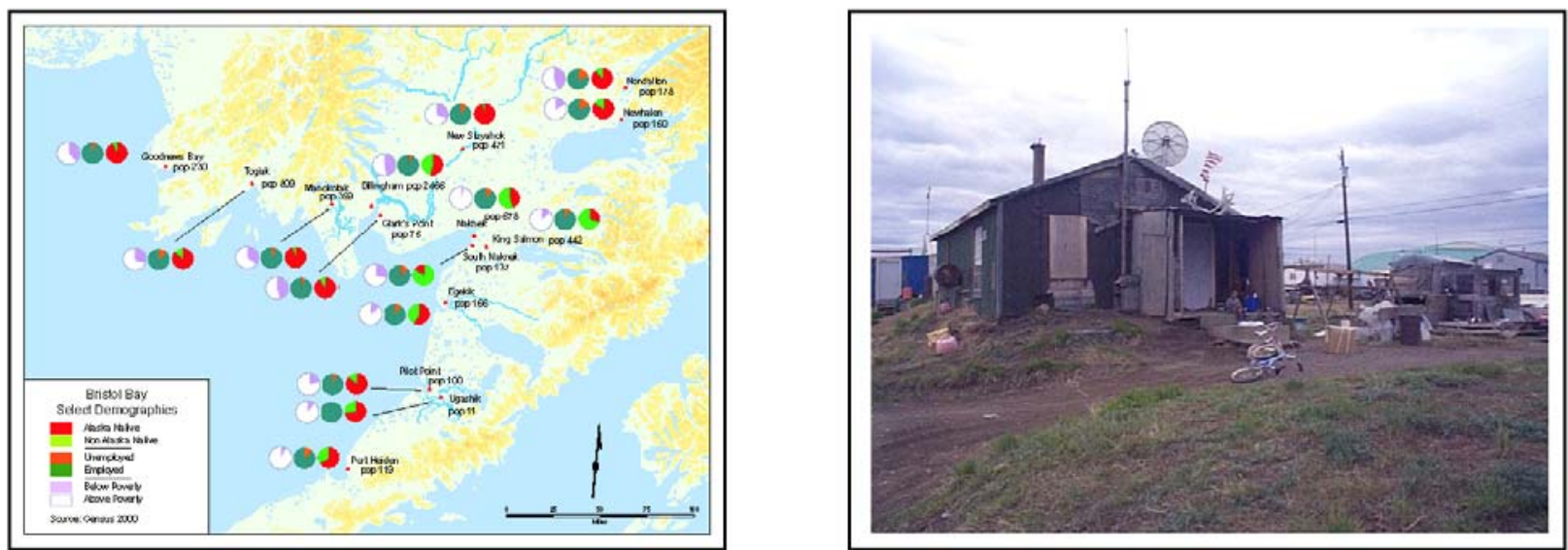
- The likely comm unity-level social and econom ic effects of development on the NAB OCS cannot be immediately analyzed or answered

- Although recent social research in the region has covered a broad geographic area (e.g., NMFS fishing community research), its dep th of coverage has generally been limited to specific programmatic needs that yield information that is useful but inadequate for generating sufficient understanding of socioeconom ic change \& its correlates

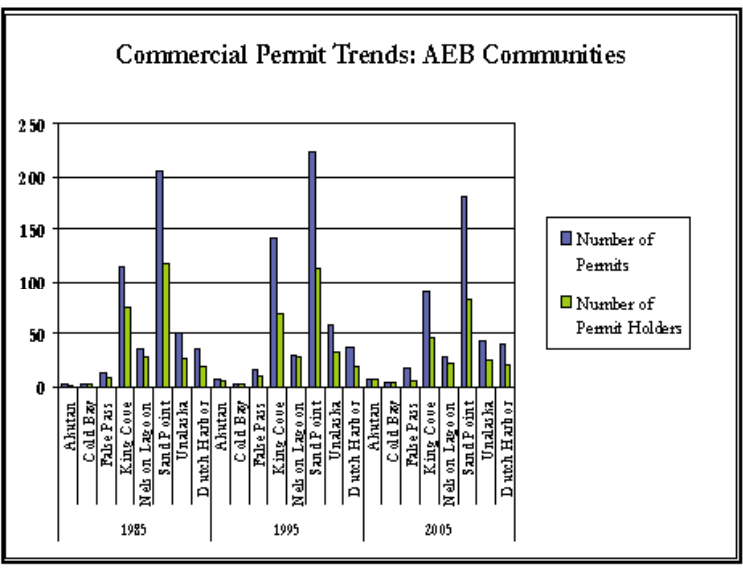

Finally, as per the logic of TR-75 and associated research, future assessment must be designed so that the effects of non-OCS sources of change (e.g., salmon abundance or lack thereof, or opportunities associated with Pebble Mine) are analytic ally controlled, thereby enabling measurem ent and adequate understanding of the potential (or actual) local and regional social and econom ic effects of specific industry actions on the NAB OCS. This is increasingly challenging given that $m$ any sources of change are now seen as global in scope and effect
- Comprehensive social assessment would require work at the level of detail previously conducted for MMS in the region, \& careful monitoring of select social and economic variables and indicators over the course of time

- Logically, the research would address the nature of participation of indigenous and non-indigenous residents in predominant \& subsidiary industries in the region; the potential nature of their involvement in, or interface with prospective oil \& gas industry activity in the $\mathrm{NAB}$; \& the dynamic-interactive effects of such participation on involvement in traditional cultural practices
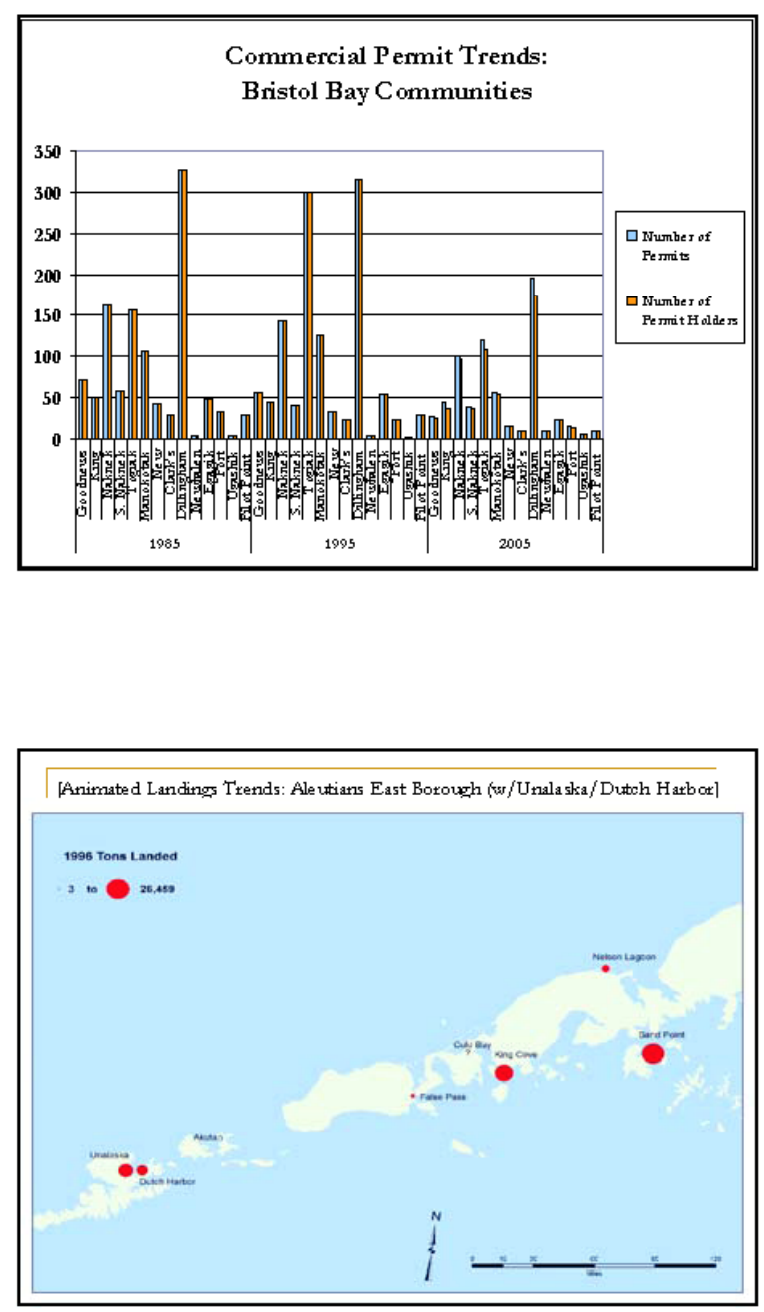

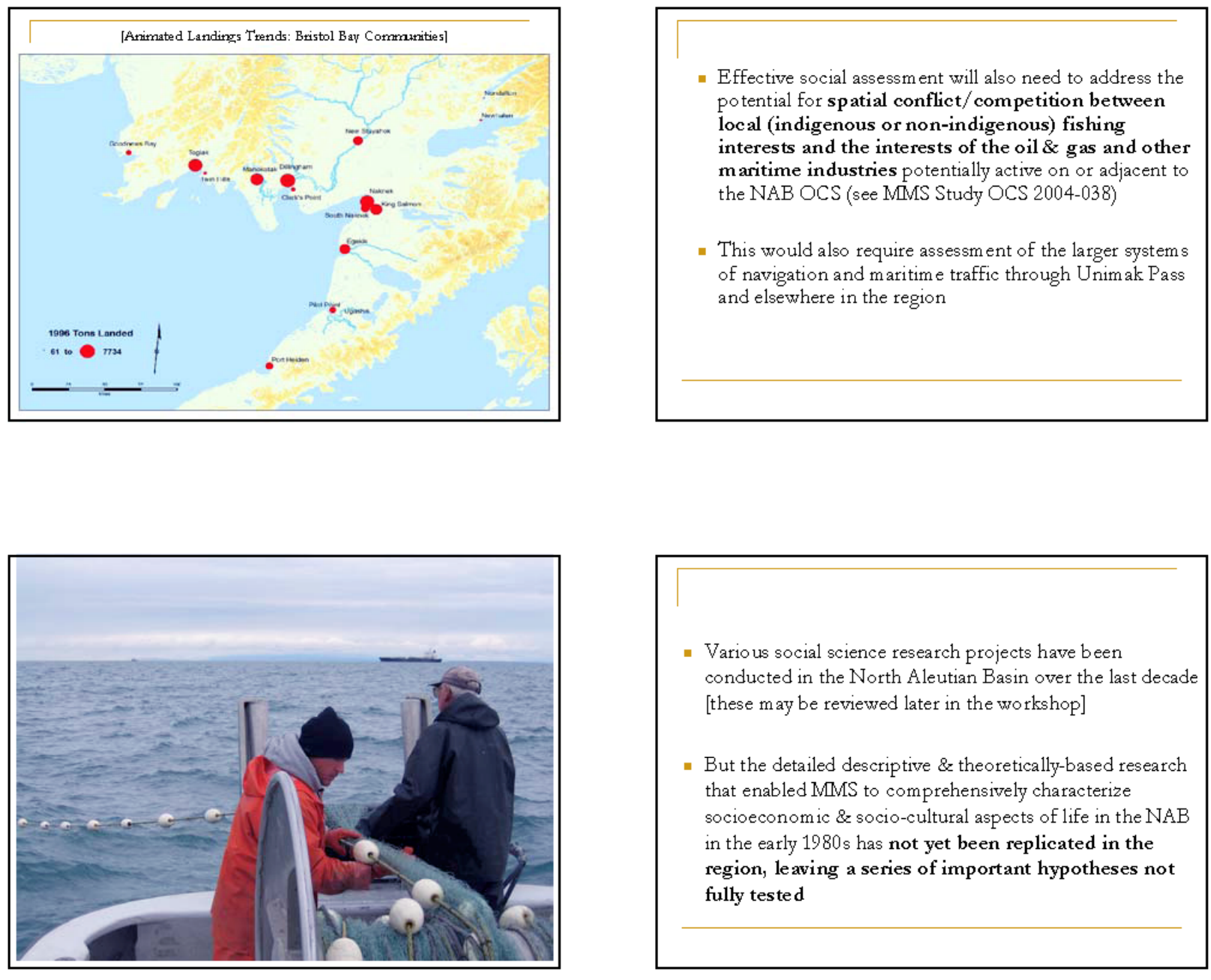

Various social science research projects have been conducted in the North Aleutian Basin over the last decade [these may be reviewed later in the workshop]

- But the detailed descriptive \& theoretically-based research that enabled MMS to comprehensively characterize socioeconom ic \& socio-cultural aspects of life in the NAB in the early 1980s has not yet been replicated in the region, le aving a series of important hypotheses not fully tested

- By comprehensively revisiting old [and new] socioeconomic variables and theoretical perspectives in advance of prospective further social change, analys ts would be able to continue the long-term systematic rese arch begun in the region in the 1980s, and in so doing:

(1) advance understanding of the human implications of OCS $s$ cen arios in the NAB, (2) satisfy NEPA- and OCSLA-related social-an alytical mandates, and (3) generate sufficient information for developing policy that could serve to enhance the life experiences of persons residing in adjacent communities 


\section{Subsistence Research in the North Aleutian Basin}

Brian Davis

Cultural Anthropologist

Former Program Coordinator, Alaska Department of Fish and Game, Division of Subsistence

November 28, 200

\section{Alaska Native Culture Groups}

- Yup'ik Eskimo: Goodnews Bay, Togiak

- Alutiiq (Aleut): King Salmon, Chignik

- Unangan Aleut: Unalaska, False Pass

- Athabaskan Indian: Pedro Bay, Naknek

\section{Major Subsistence Resources:}

Northern Aleutian Basin
- Salmon
- Caribou
- Halibut
- Moose
- Whitefish
- Harbor Seals
- Herring/Herring Roe
- Sea Lions
- Smelt
- Beluga Whale
- Cod
- Ducks
- Ptarmigan
- Sea Gull Eggs
- Clams
- Tanner Crab
- Beaver
- BemiesNegetation

\section{Subsistence Research:} Government

- ADF\&G, Division of Subsistence

- ADF\&G, Divison of Commercial Fisheries

- USF\&WS, Migratory Birds, Marine Mammals

- NOAA/NMFS, Marine Mammals, Halibut

- USF\&WS, Office of Subsistence Management

\section{What Is Subsistence?}

- A Legally Defined Harvest or Use - State-Stock and Location

- Federal-Residence and Alaska Native - Permitted, Regulated, and Non-

- Any Rural Alaskan Harvest

- Customary Harvests

- Cultural Values Related To Harvest
*Subsistence Research: Alaska Native Organizations

- BBNA

- AIPIA

- Alaska Native Harbor Seal Commission (ANHSC)

- The Alaska Sea Otter-Steller Sea Lion Commission (TASSC)

- Aleut Marine Mammal Commission (AMMC)

- Qayasiq Walrus Commission (BBNA) 
Subsistence Research: Independent Contractors

- Steve Braund \& Associates

- Herbert Maschner- Idaho State University

- Robert Wolfe \& Associates

- University of Alaska, ISER

- The Nature Conservancy
Subsistence Research: Focus Areas

1. Subsistence Foods Safety

2. Subsistence Traditions, Customs, Education

3. Subsistence Land Use Mapping

4. Subsistence Harvest Assessment

\section{Subsistence Foods Safety}

- APIA, Nat. Inst Env HIth Sci: Traditional Foods Dietary Benefits and Risks (Atka, St. Paul)

- APIA, ANTHC: Maternal/Infant Health

- APIA: PSP Project, Sand Point, Unalaska

- ANHSC, NOAA: Harbor Seal Biosampling

- TASSC, USEPA: Contaminant Testing, Sea Gull Eggs, Togiak, Unalaska

\section{Subsistence Traditions,} Customs, Education

- Tribal Culture Camps: Unalaska, King Cove

- Alaska Native Knowedge Network

- TEK: ADF\&G, Bristol Bay/Aleutian Islands' Fisheries

- TEK: BBNA, Togiak TEK

- Customary Trade: BBNAADF\&G

\section{*3. Subsistence Land Use:} Mapping

- Harvest Locations: Point Data

- Hunting/Fishing Locations: Polygon Data

- Routes, Trails, Cabins, Access

- Intensity of Use

- Harvest Concentration

- Duration: 5-year, 10-year, lifetime

- Confidentiality, Anonymity

- Non-Harvest Mapping: Ecological observations

\section{Subsistence Harvest}

\section{Assessment: Organizations}

ADFG, Division of Subsistence: Community Harvest Baseline Data. Harvest Estimates and Participation Levels.

ADFG, Division of Commercial Fisheries: Permitted Subsistence Fisheries (Salmon, Crab

USF\&WS: Migratory Bird Harvest Survey

NOAANMFS: Subsistence Halibut Fishery

ANHSC: Harbor Seal and Steller Sea Lion Harvest

St. Paul Island Ecosystem Office: Fur Seal Harvest

Qayasiq Walrus Commission: Round Island Walrus Harvest 


\section{Subsistence Harvest Assessment} Data

- A. ADF\&G Division of Subsistence, Community Studies-- Baseline and Directed

- B. ADF\&G, Division of Commercial Fisheries, Bristol Bay Salmon Permit Data, 2003

- C. NOAA/NMFS, Subsistence Halibut Harvest, By Community, 2003-2004

- D. ANHSC, Marine Mammal Harvest, By Community, 1992-2004

- E. USF\&WS, Migratory Bird Harvest, 2004 2005, Not Yet Available
A-1. Subsistence Harvest: Participation Rates, Major Resource Categories. South Naknek, 1992

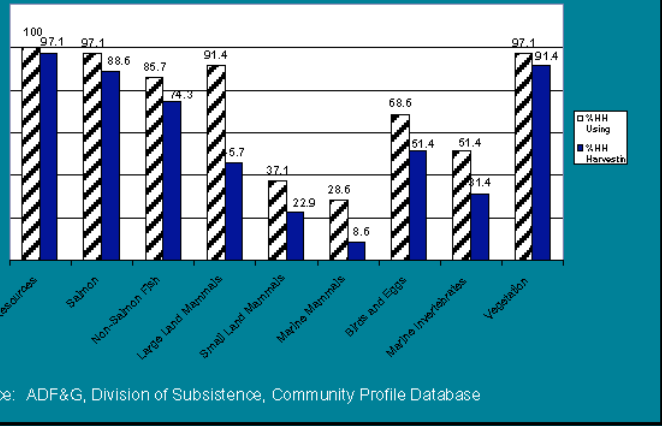

A-2. Subsistence Harvest: Percent of Households Harvesting, By Resource: South Naknek, 1992

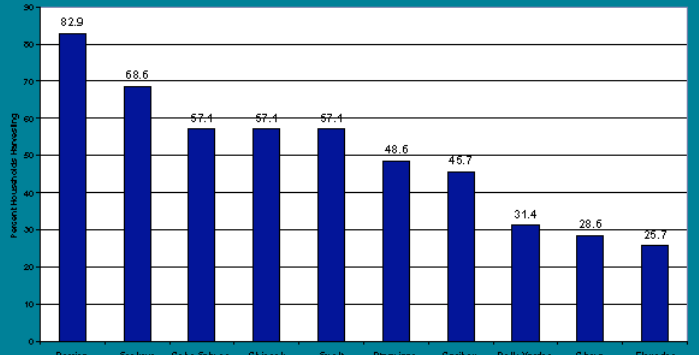

A-4. Subsistence Harvest Data: ADF \&G Baseline Studies By Year

- Manokotak: 1985

- Nelson Lagoon, 1987

- Clark's Point, 1989

- Sand Point, 1992

- Dillingham, 1984

- King Cove, 1992

- Naknek, 1983

- False Pass, 1988

- South Naknek, 1992

- Akutan, 1990

- King Salmon, 1983

- Unalaska/Dutch Harbor 1994

- Egegik, 1984

- Nikolski, 1990

- Port Heiden, 1987

- Chigniks, 2003

- Perryville, 2003
${ }^{*}$ A-3. Subsistence Harvest: Top Species in Pounds Usable Weight, Unalaska, Chignik Lake South Naknek
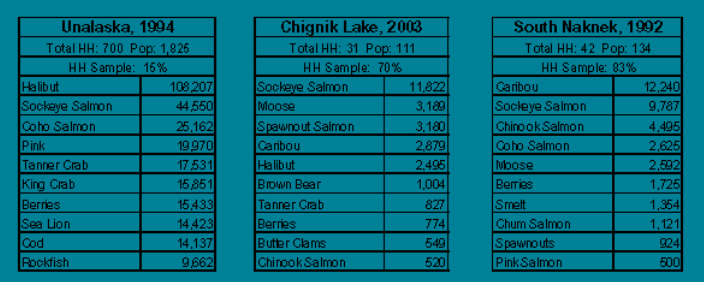

Source: ADF\&G, Division of Subsistenœ, Community Profile Database

\section{A-5. Subsistence Harvest Data:} ADF \&G Directed Studies

- Birds and Eggs: Akutan, False Pass, Nikolski, Nelson Lagoon, 1996

- Large Land Mammals: 12 Alaska Peninsula Communities, 1995-1997

- Large Land Mammals: Clark's Point, Manokotak, Portage Creek, Togiak, Twin Hills, 2001-2002

- Marine Mammals: Nearly All Communities, 1994-2004 
B-1. Subsistence Salmon Permit Harvest: All Bristol Bay Region, 1993-2003

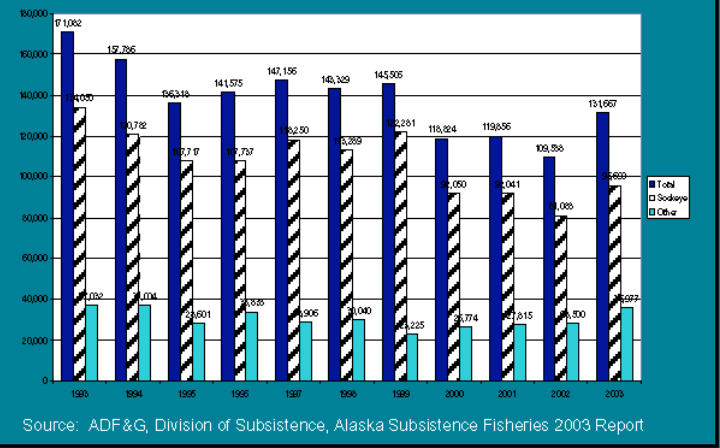

C-1. Subsistence Halibut Harvest: Reporting Communities, 2004

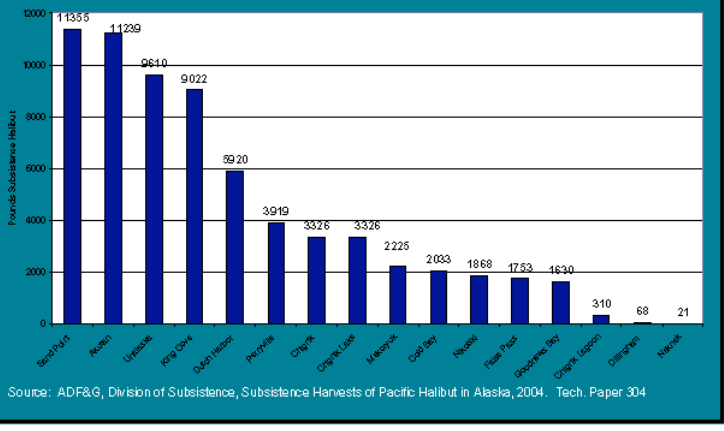

D-2. Harbor Seal Harvest: Egegik Naknek, 1992-2004

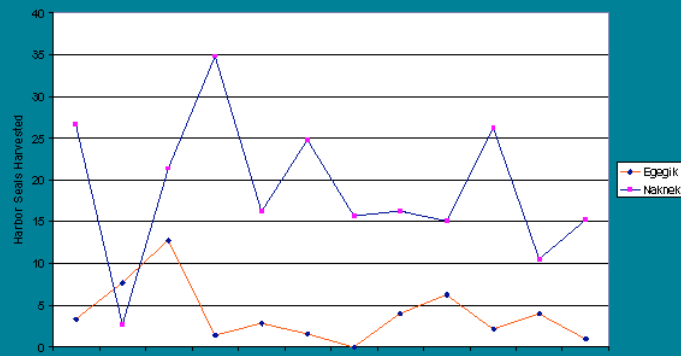

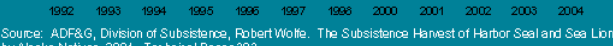

*B-2: Bristol Bay Communities,

Total Salmon Harvest, 2003
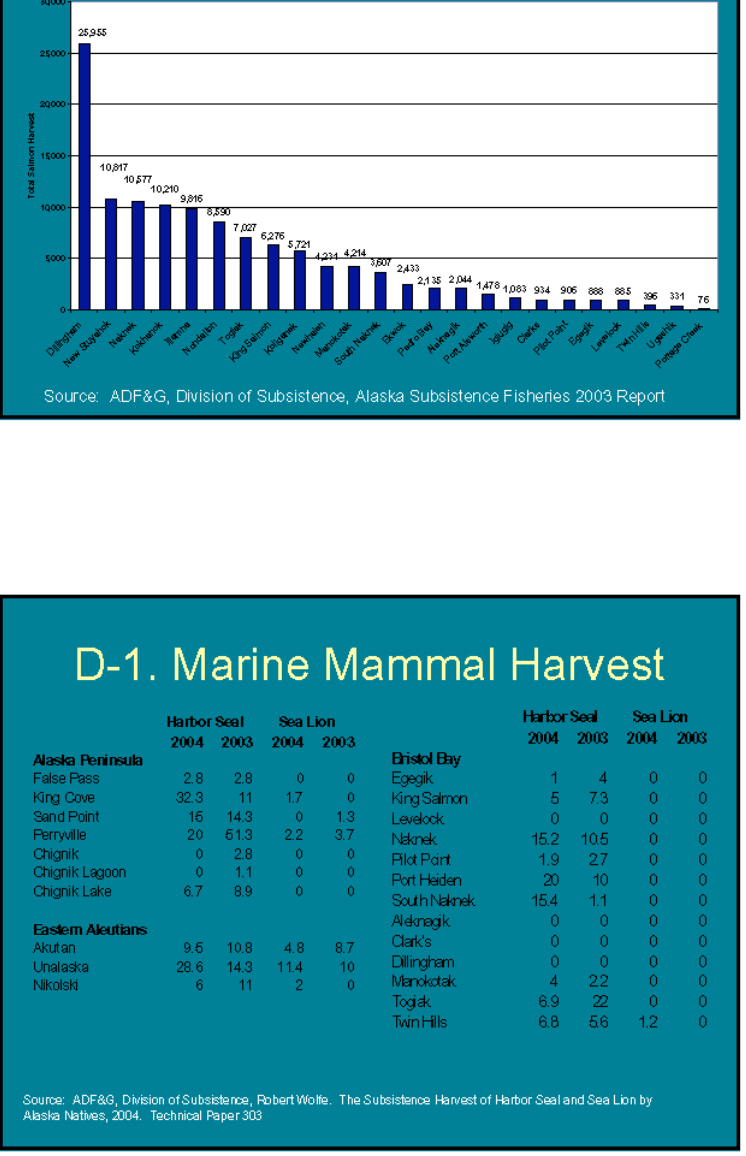

\section{Subsistence Web Sites}

- ADF \&G, Division of Subsistence:

Aww subsistence adfg. state ak us

- AMMC: maraleutmarinemammals.org

- ANHSC: Www harborsealcommission org

- ANKN: wmav ankn uaf edu

- TASSC mmuseaotter-sealion org

- APIA: wmw apiai org

- BBNA: wrmbbna com

NOAA Subsistence Halibut

mm. fakr noaa gov/ram/subsistence/halibut.htm

- USF\&WS Sub Mgmt: alaska.fws.gov/asm/home 


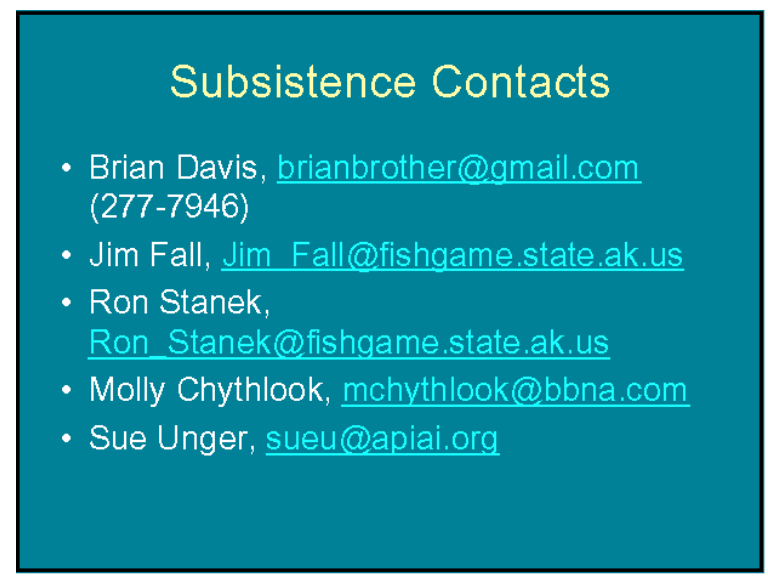




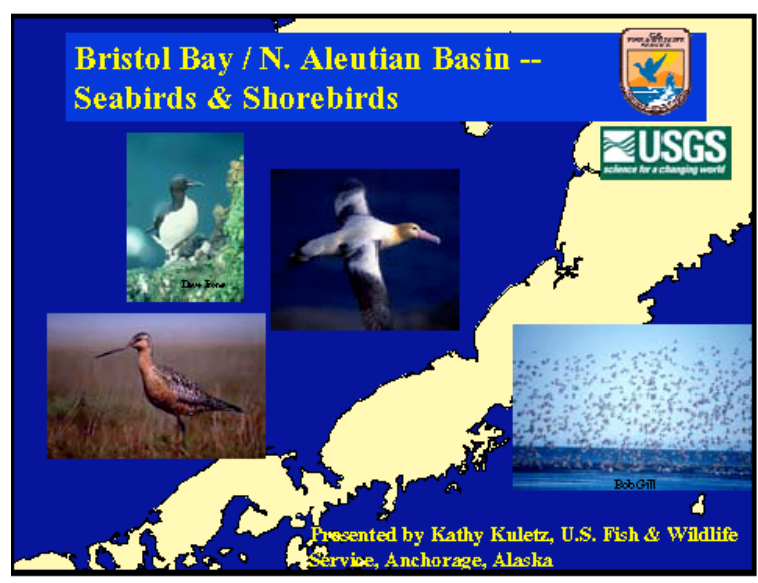

\section{SHOREBIRDS}

-Up to $1 / 3$ of the world population of Bar-tailed Godwits use Egegik Bay in fall

-The only nesting ar ea for a subspecies of Marbled

Godwit is found in the Bristol Bay Lowlands
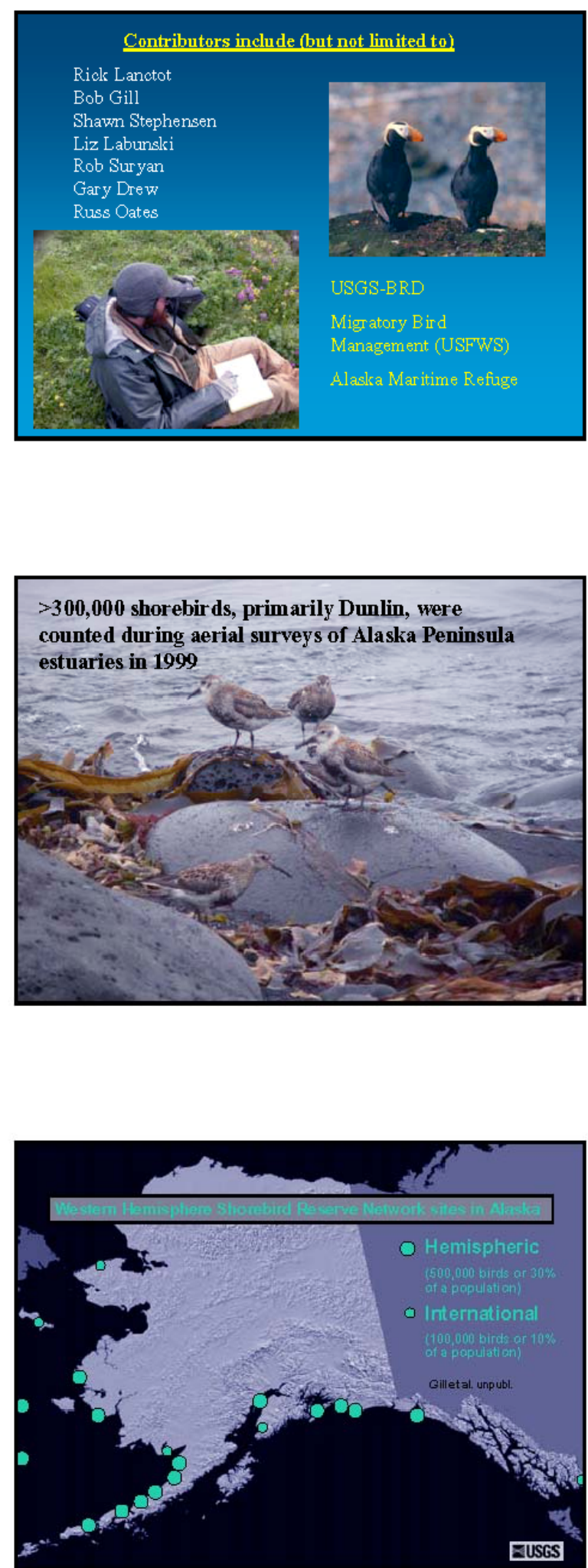

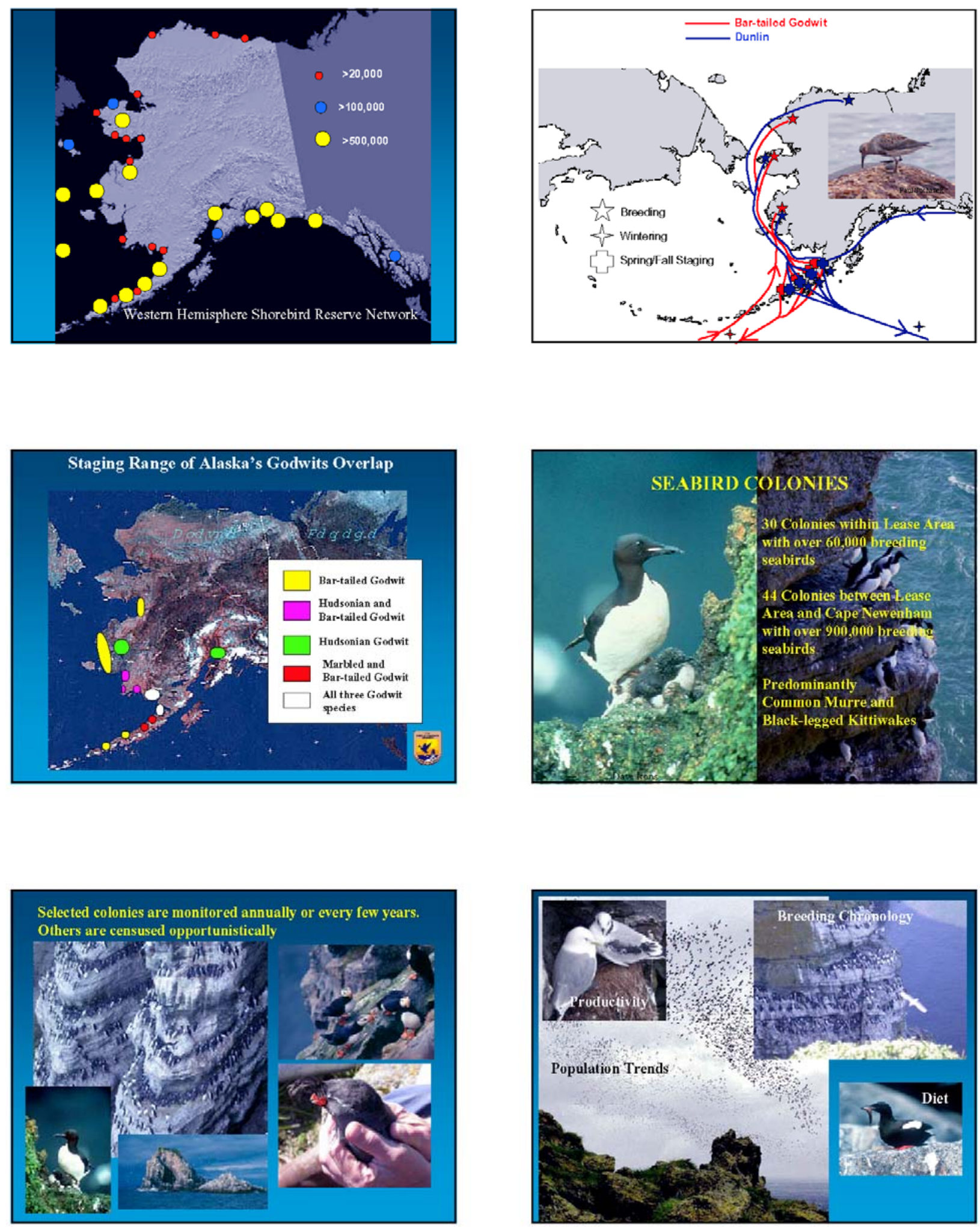

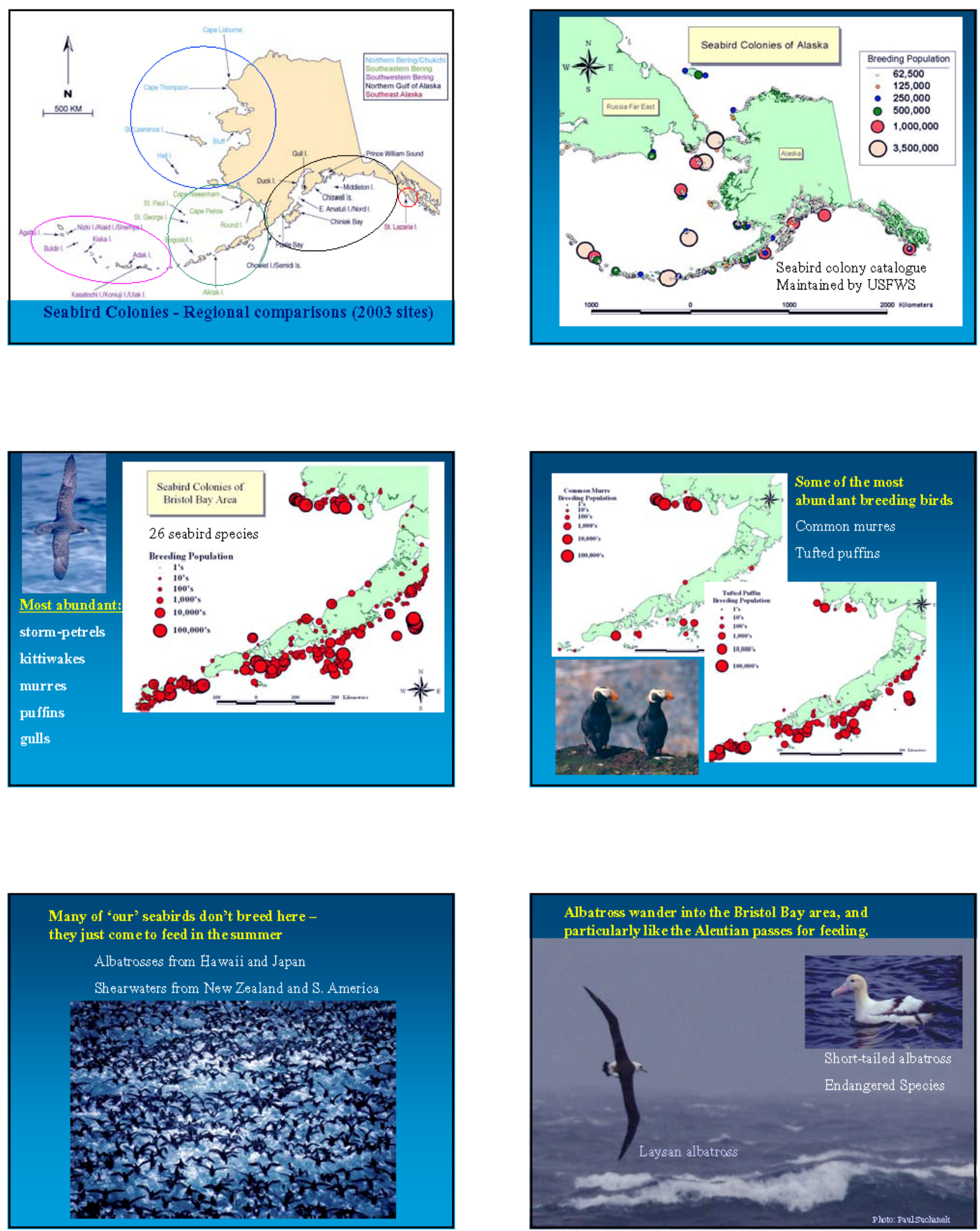

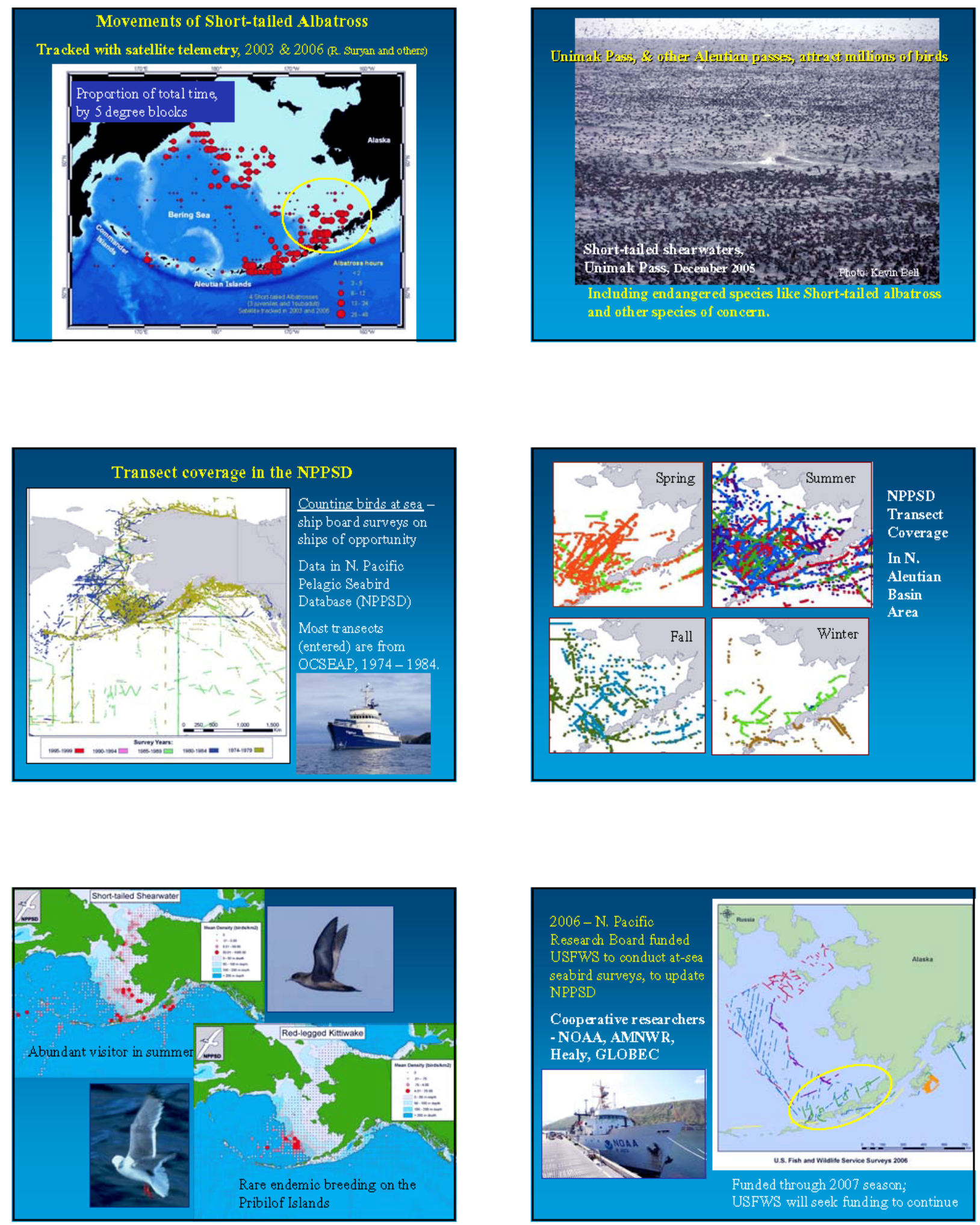

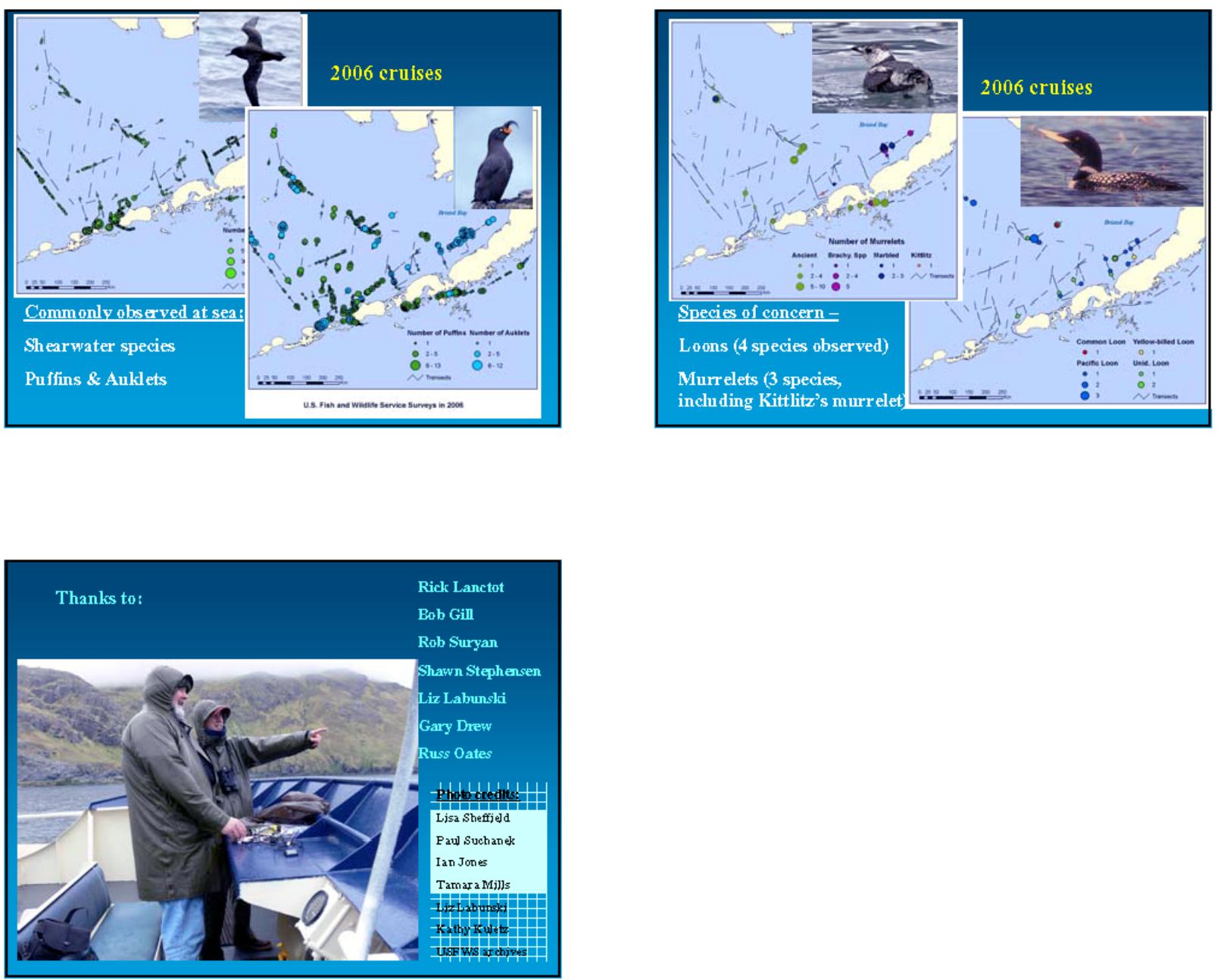

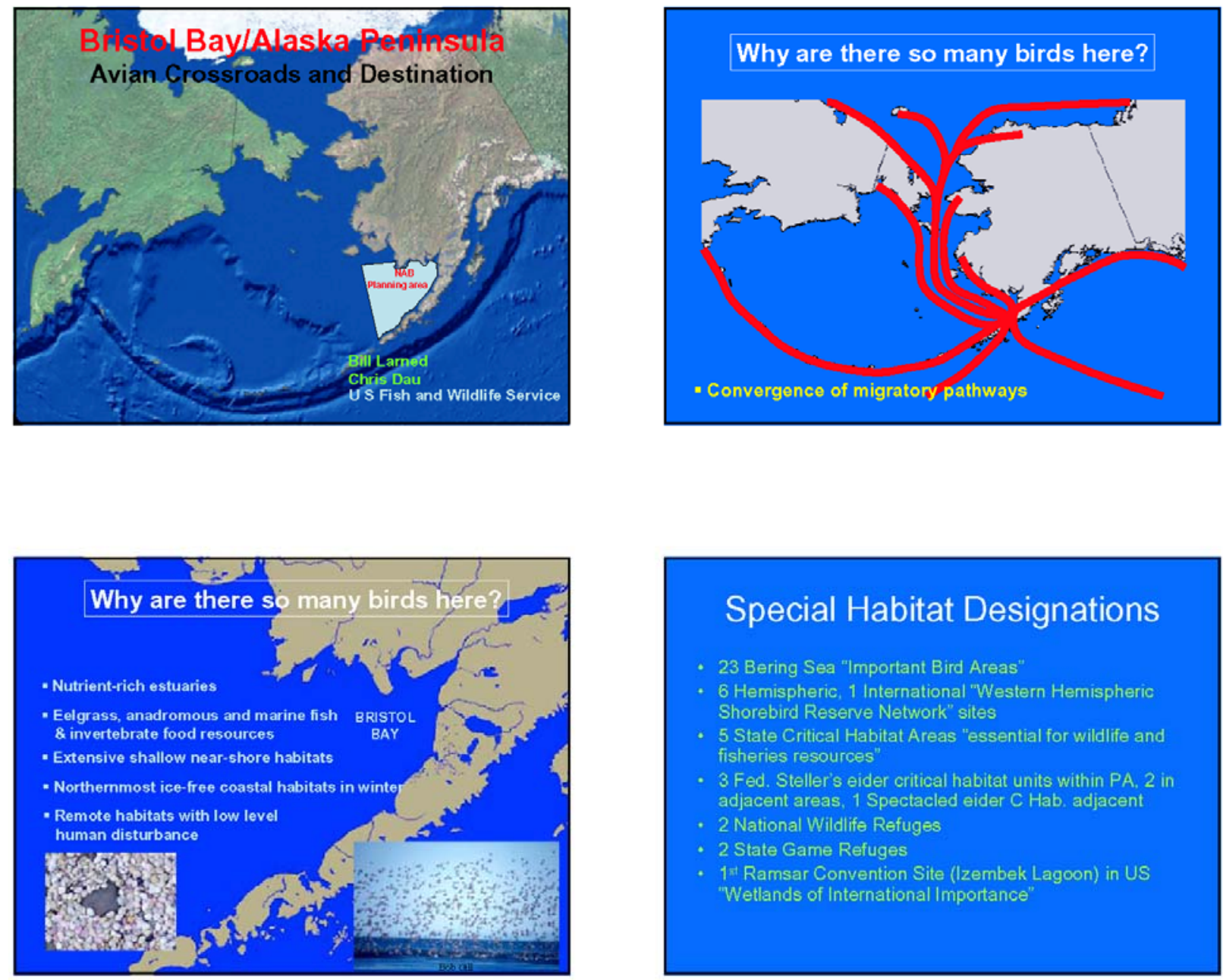

\section{Special Habitat Designations}

- 23 Bering Sea "Important Bird Areas"

6 Hemispheric, 1 International "Western Hemispheric Shorebird Reserve Network" sites

5 State Critical Habitat Areas "essential for wildlife and fisheries resources"

- 3 Fed. Steller's eider critical habitat units within PA, 2 in adjacent areas, 1 Spectacled eider $\mathrm{CHab}$. adjacent

2 National Wildlife Refuges

2 State Game Refuges

1잘 Ramsar Convention Site (Izembek Lagoon) in US "Wetlands of International Importance"

\section{WATERBIRDS MOST AT RISK}

- Sea Ducks:

Long-tailed duck,

- Geese:

Cackling

Canada goose

- Other dabbling/diving/sea ducks, loons, grebes, gulls in estuaries and along shorelines esp. during spring/fall migration

\section{Data Sources}

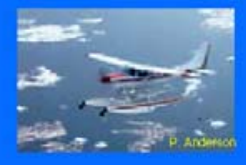

FWS Aerial Surveys - Spring Staging, Winter, Molting, Fall Staging, including: sea ducks, other diving ducks, dabbling ducks, geese, loons, grebes, gulls, eagles

Many estuarine studies (marine ecology, abundance. biology, disturbance factors of waterbirds)

- Radiotelemetry - VHF and Satellite

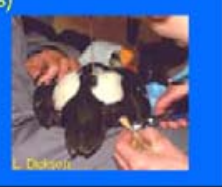



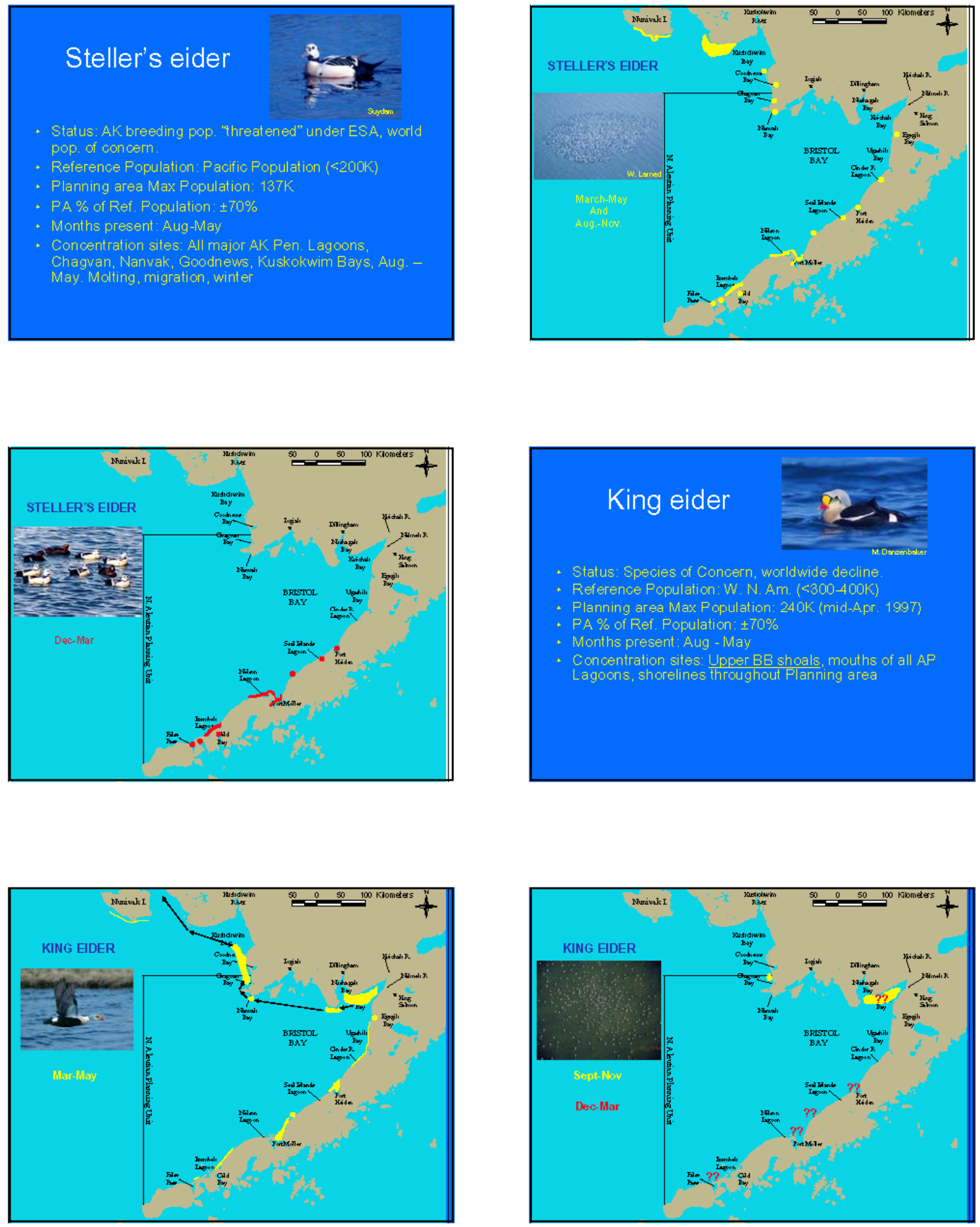

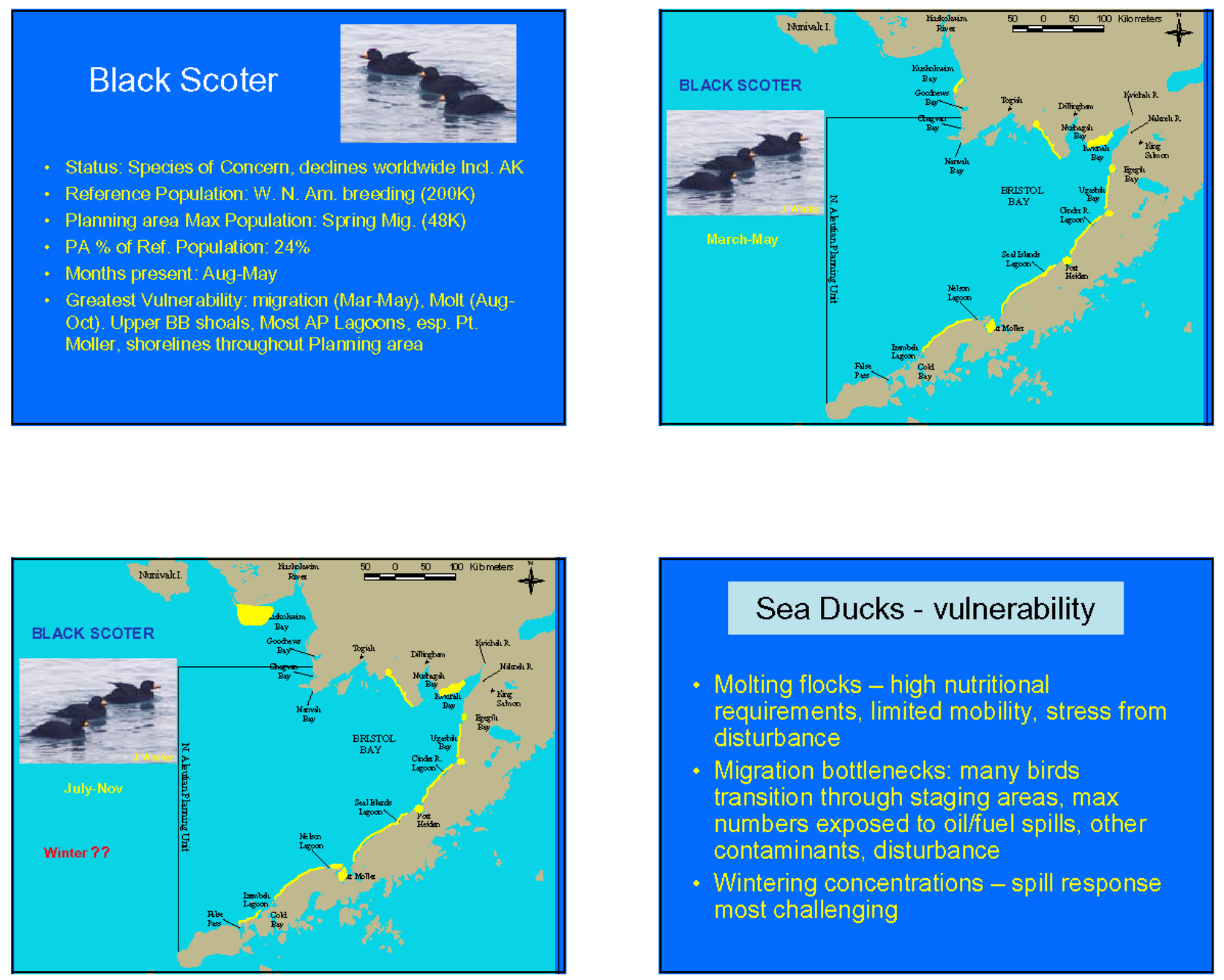

\section{Sea Ducks - vulnerability}

- Molting flocks - high nutritional requirements, limited mobility, stress from disturbance

- Migration bottlenecks: many birds transition through staging areas, max numbers exposed to oil/fuel spills, other contaminants, disturbance

- Wintering concentrations - spill response most challenging

\section{DATA GAPS}

- Baseline food resource quant/qual data from major coastal/estuarine habitats (prey density, distribution, competitors, contaminants)

- Year-round distribution of sea ducks -especially winter distribution.

- Relationships of seasonal waterbird distribution \& migration to environmental variables, esp. sea ice, weather, prey distribution/abundance, disturbance

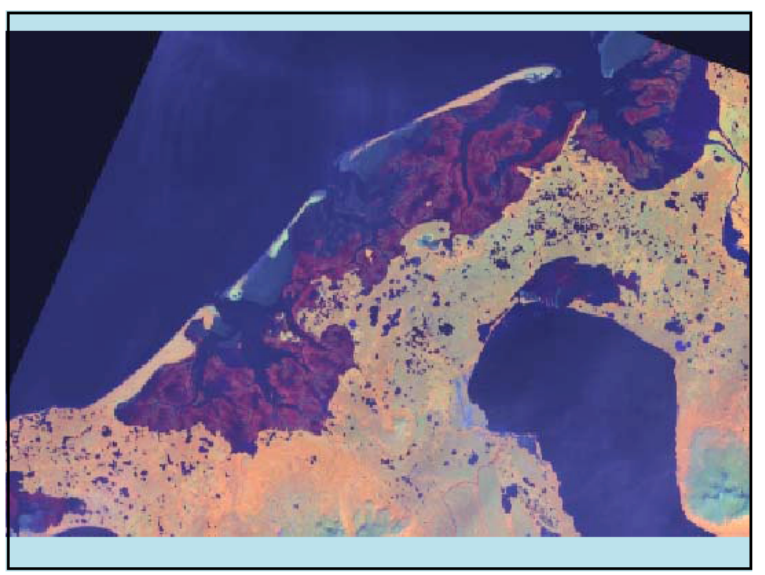




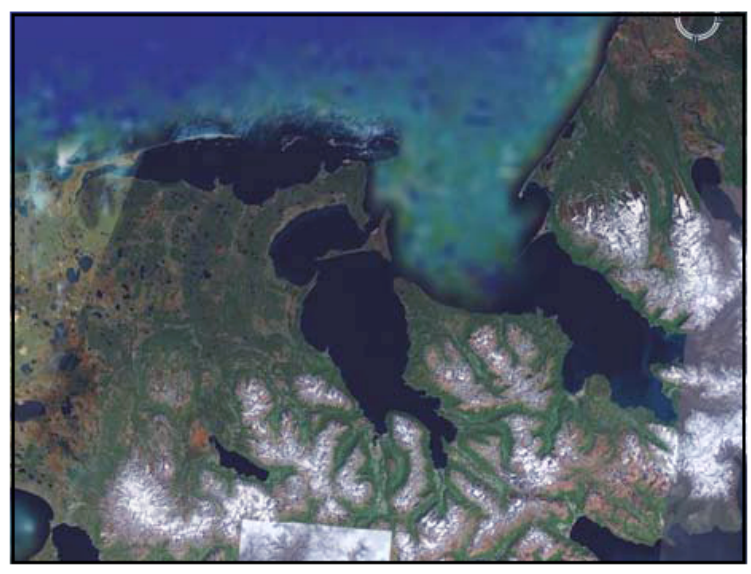

\section{Pacific Brant}

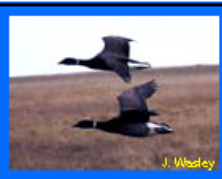

- Status: International Species of concern due to $\sim 40 \%$ reduction in population

- Reference Population: Pacific Coast and High Arctic, breeds in AK, Canada, Russia: $\sim 120 \mathrm{~K}$

- NAB Planning area Max Population: $>95 \%$

- Months present: Sept-May

- Concentration sites: Izembek Lagoons,

Bechevin, Chagvan, Nanvak Bays, Sept-Nov, April-May
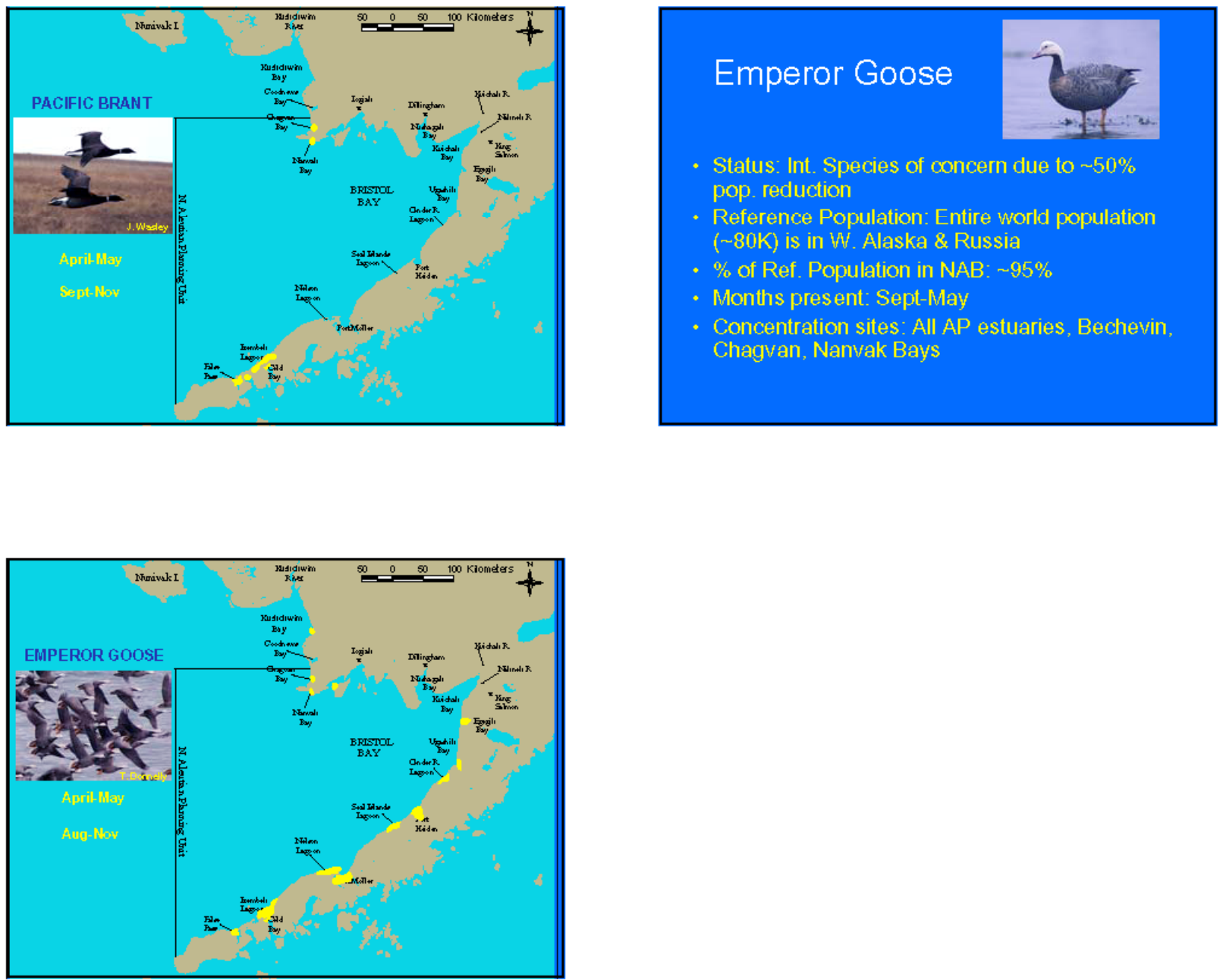


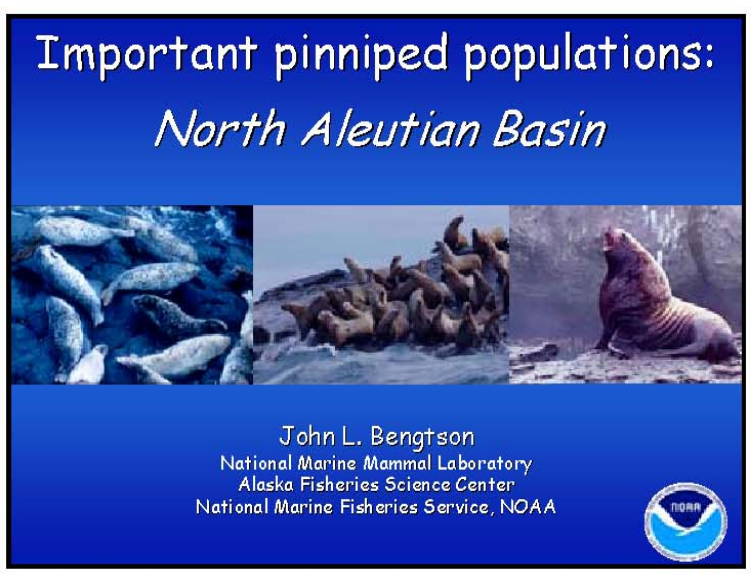

\section{Important pinniped populations:}

Distribution
\& habitats

Life

What critical information gaps concerning pinniped populations need to be addressed to assess the potential impacts of

oil and gas development in the North Aleutian Basin?
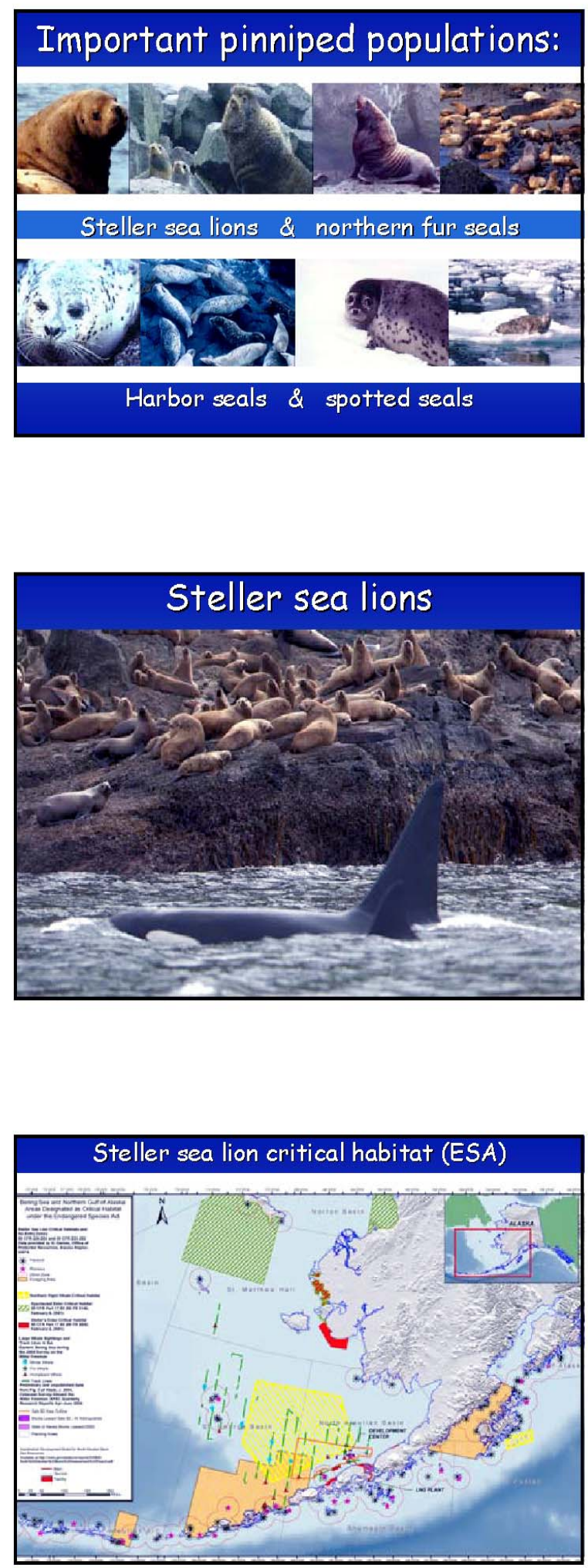

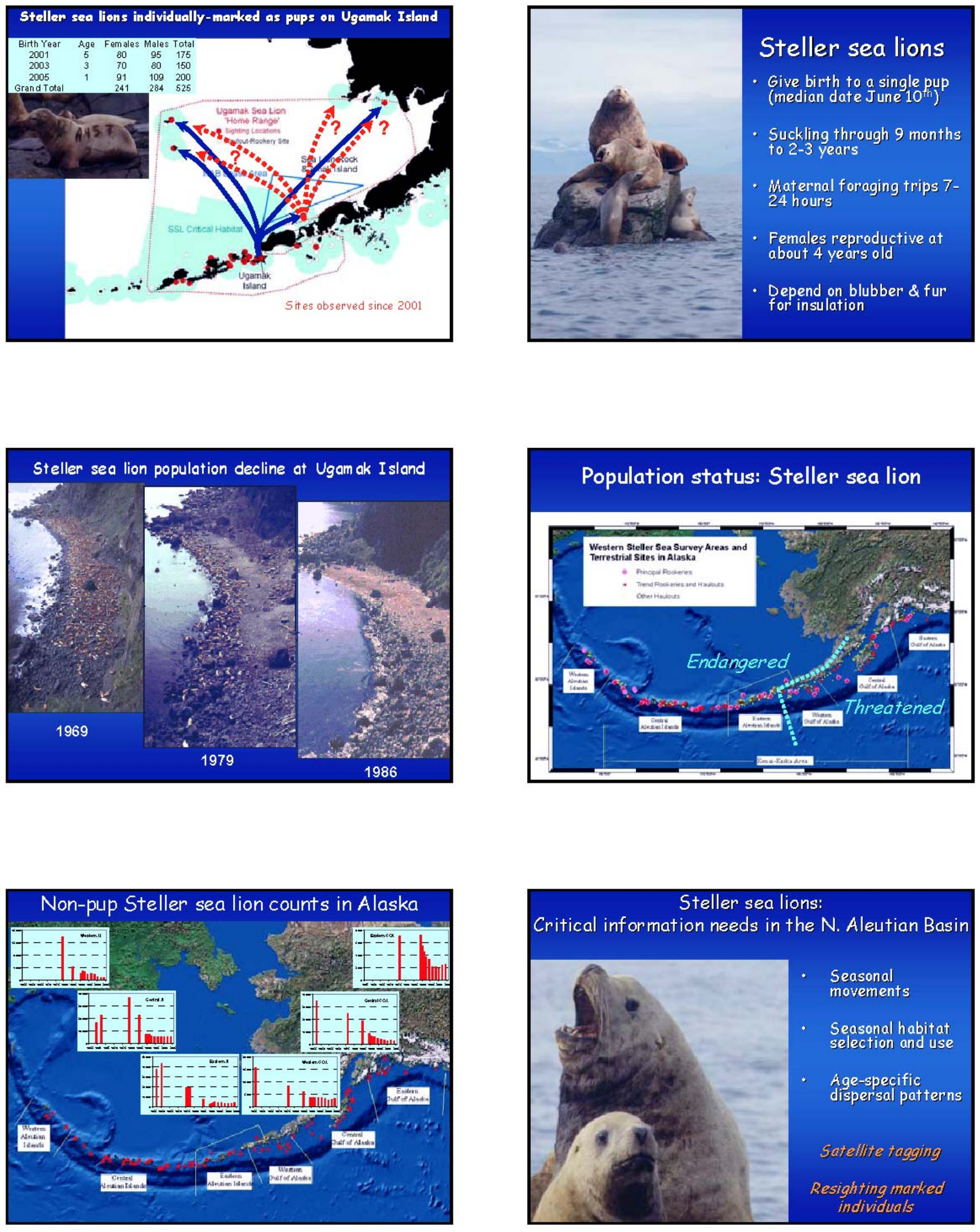

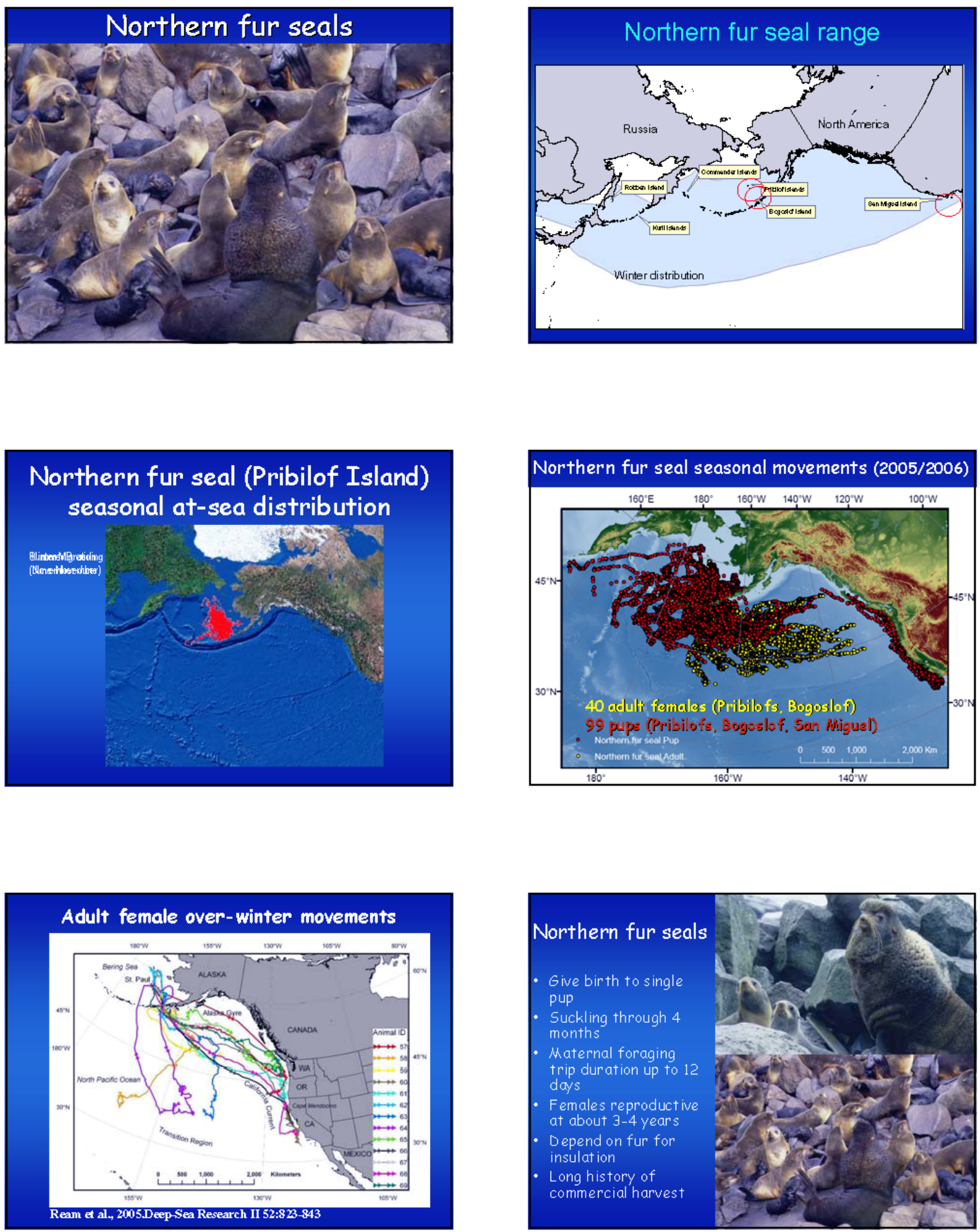

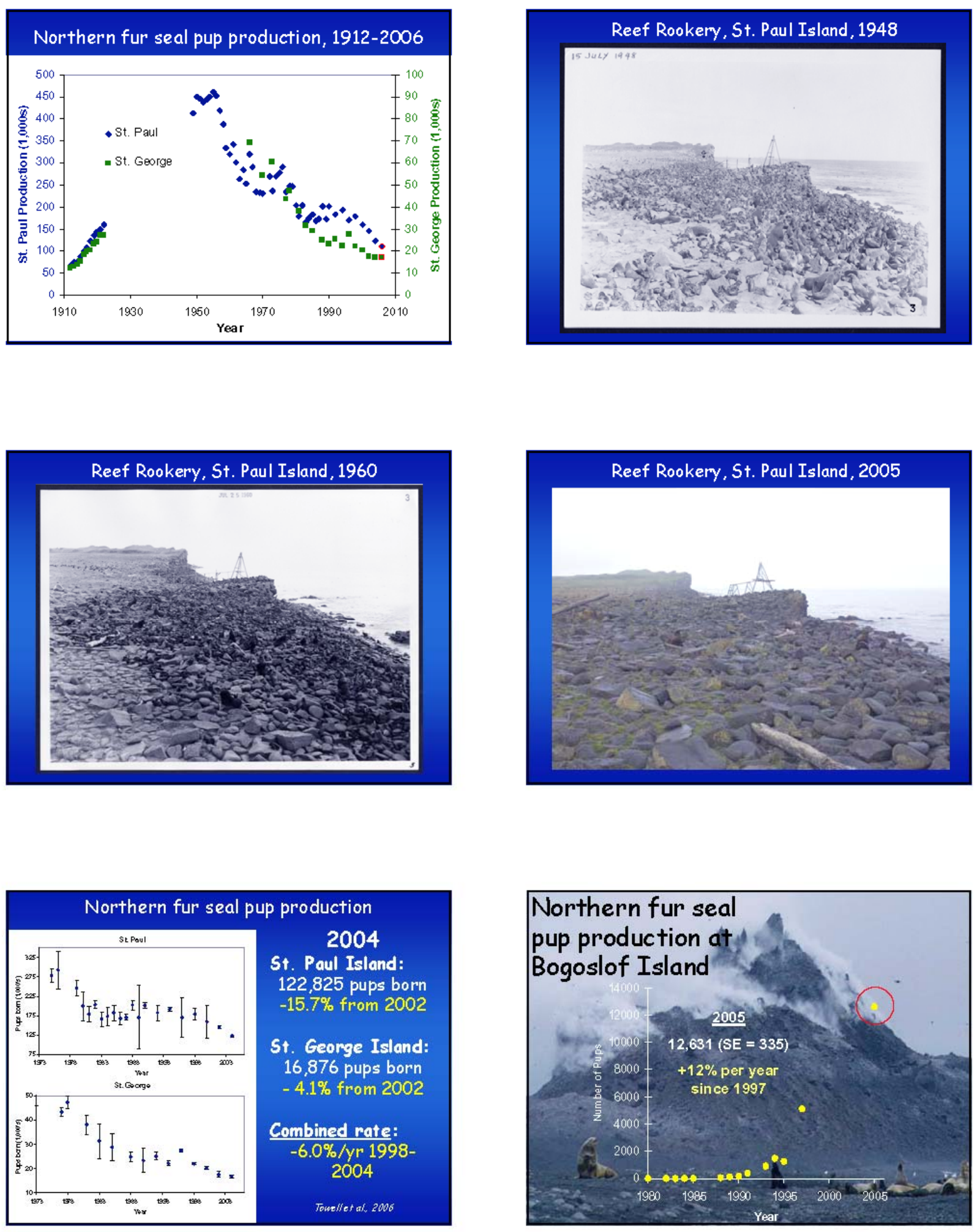

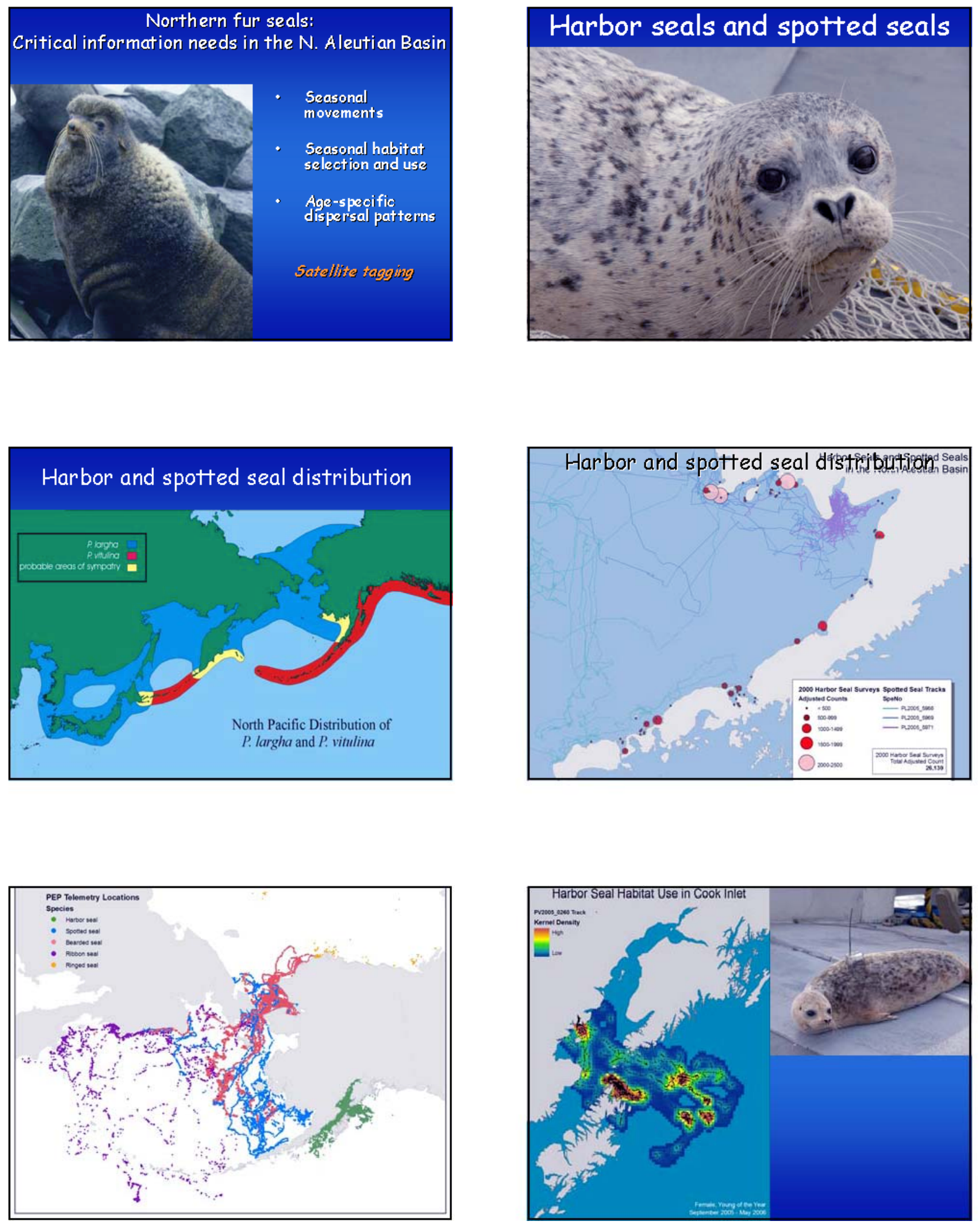

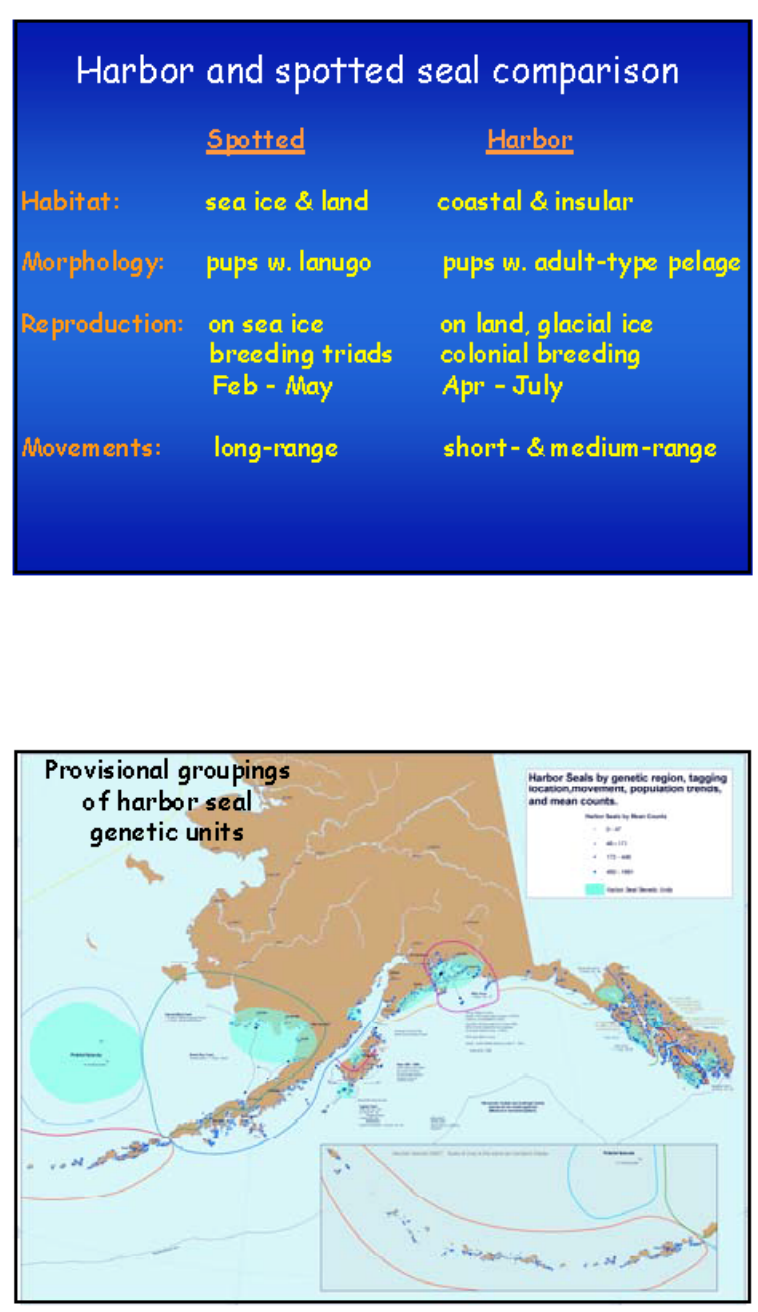

Harbor and spotted seals:

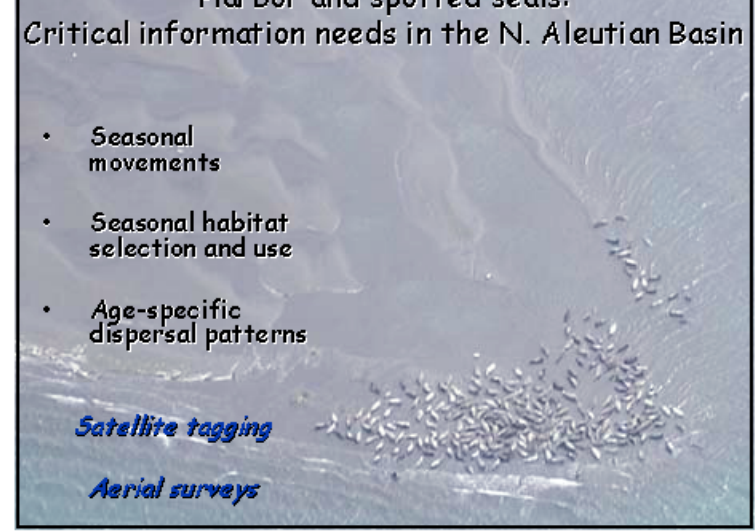

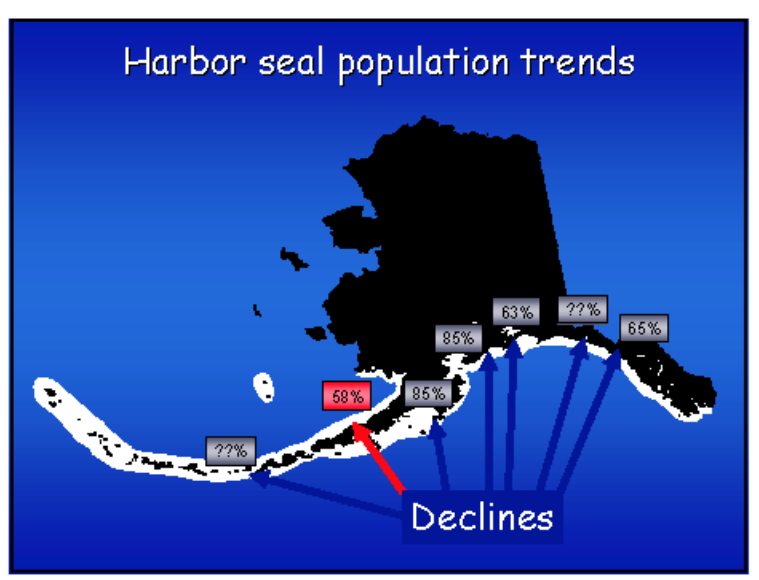
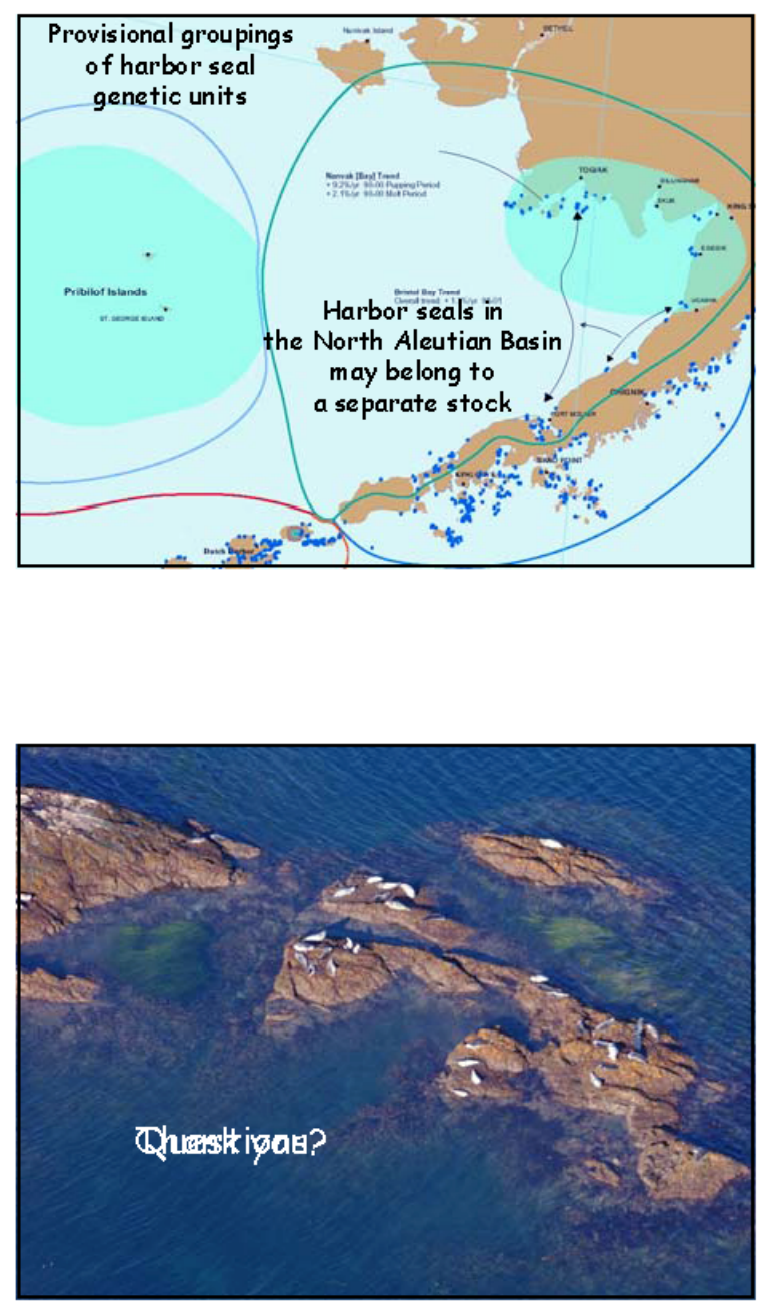

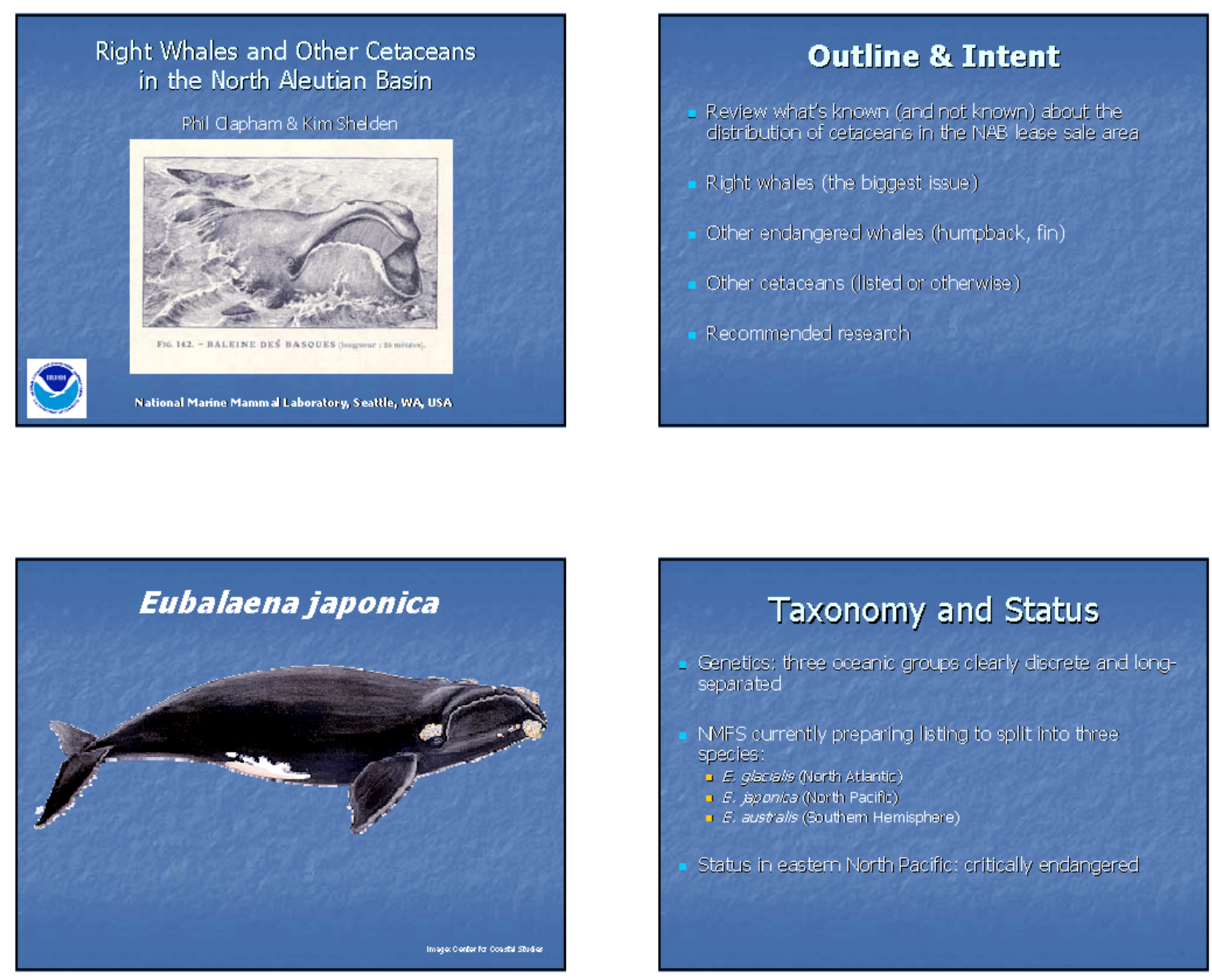

\section{North Pacific: Whaling History}

Began in 1835 on the Northwest Ground

Depleted by 1849

\lrcorner Whalers moved into the western North Pacific by 1845

\lrcorner $21,0000-30,000$ whales killed in the 1840 's

Some whalling in the early $20^{\text {th }}$ century

Eastern and Western North Pacific RW populations considered separate

\section{Disappearing Whales}

-1941-1964: 598 sightings east of 180 1965-1999: 82 sightings

- Where did they all go?

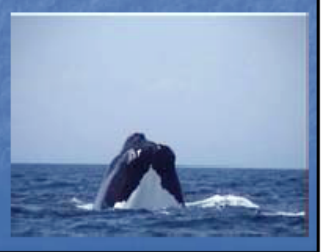



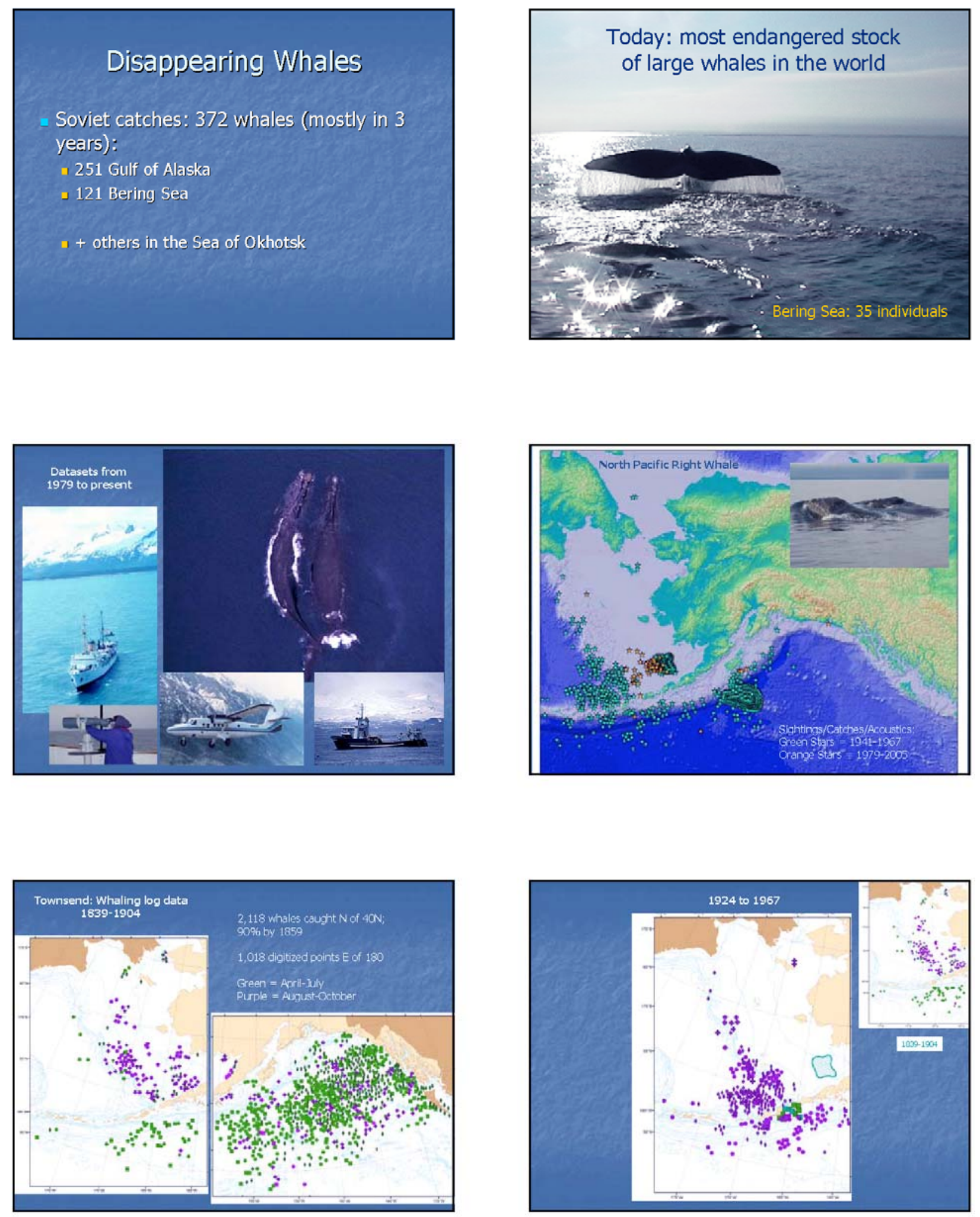

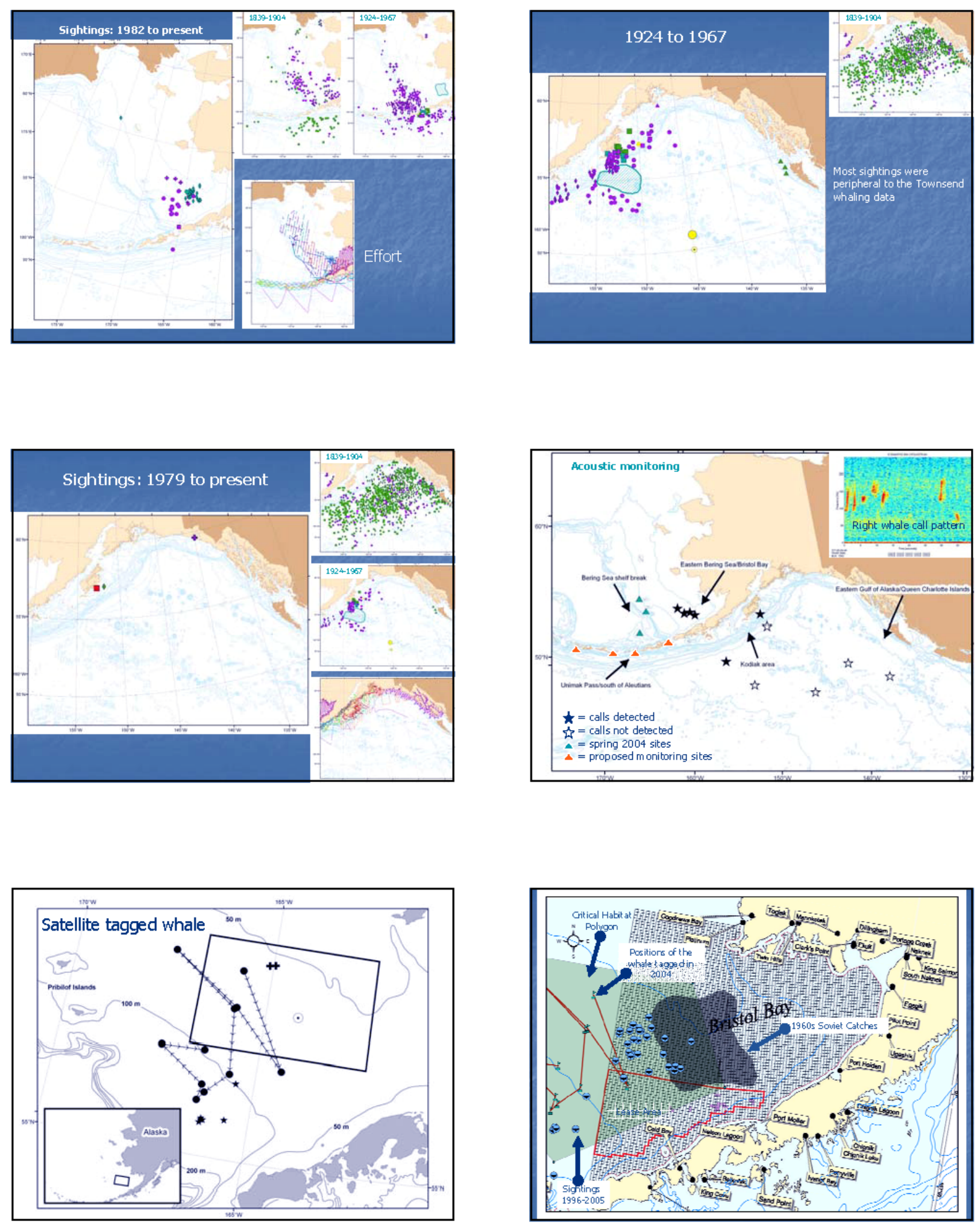

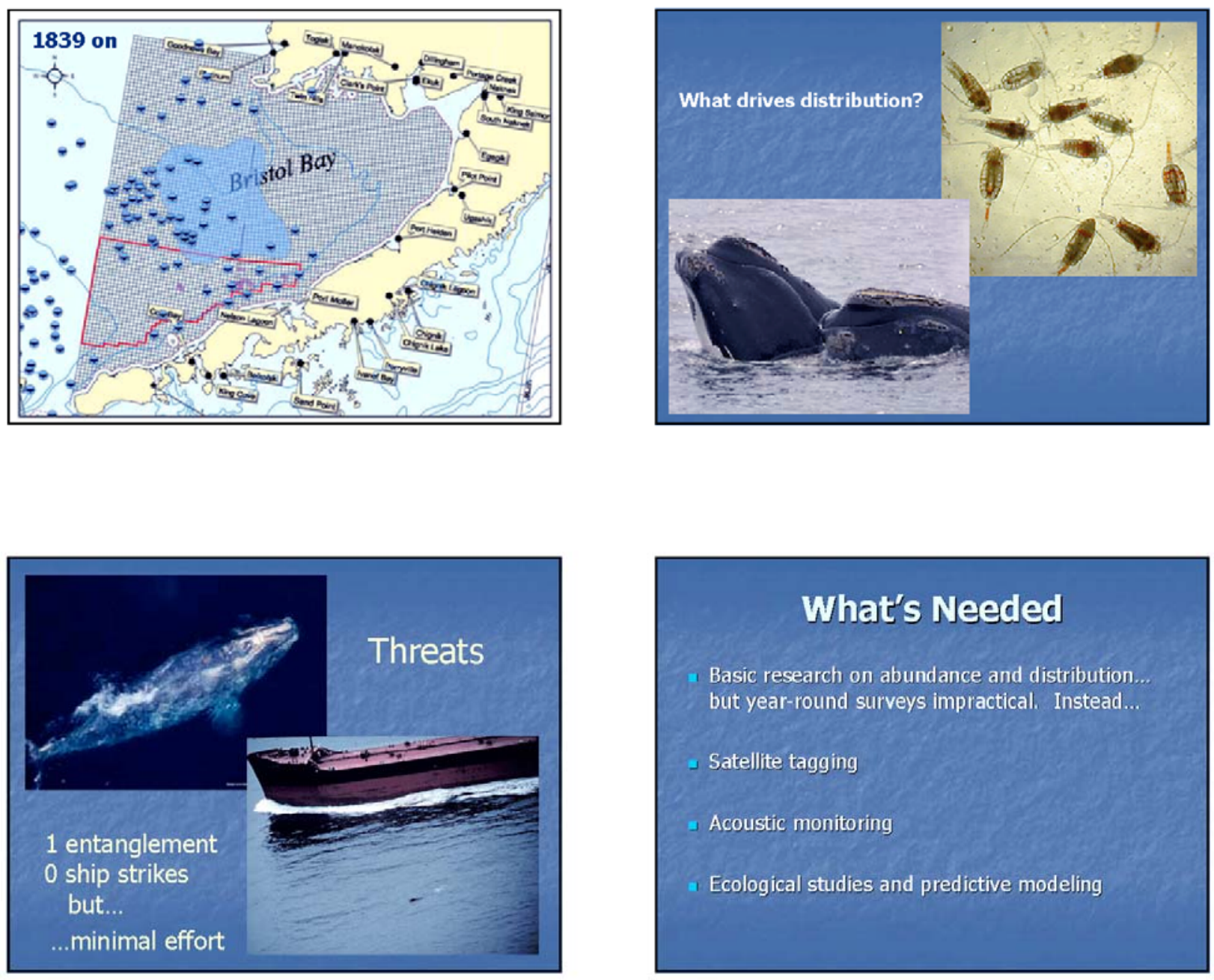

\section{What's Needed}

Basic research on abundance and distribution. but year-round surveys impractical. Instead.

Satellite tagging

Acoustic monitoring

Ecological studies and predictive modeling

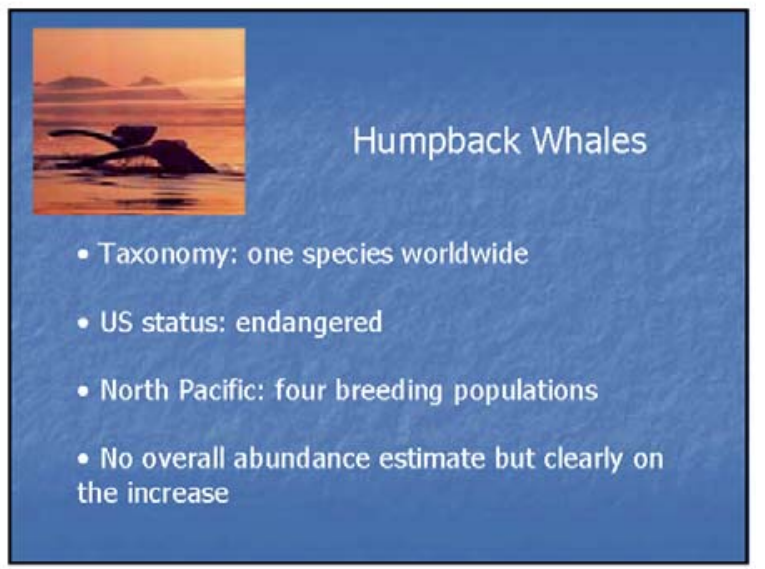



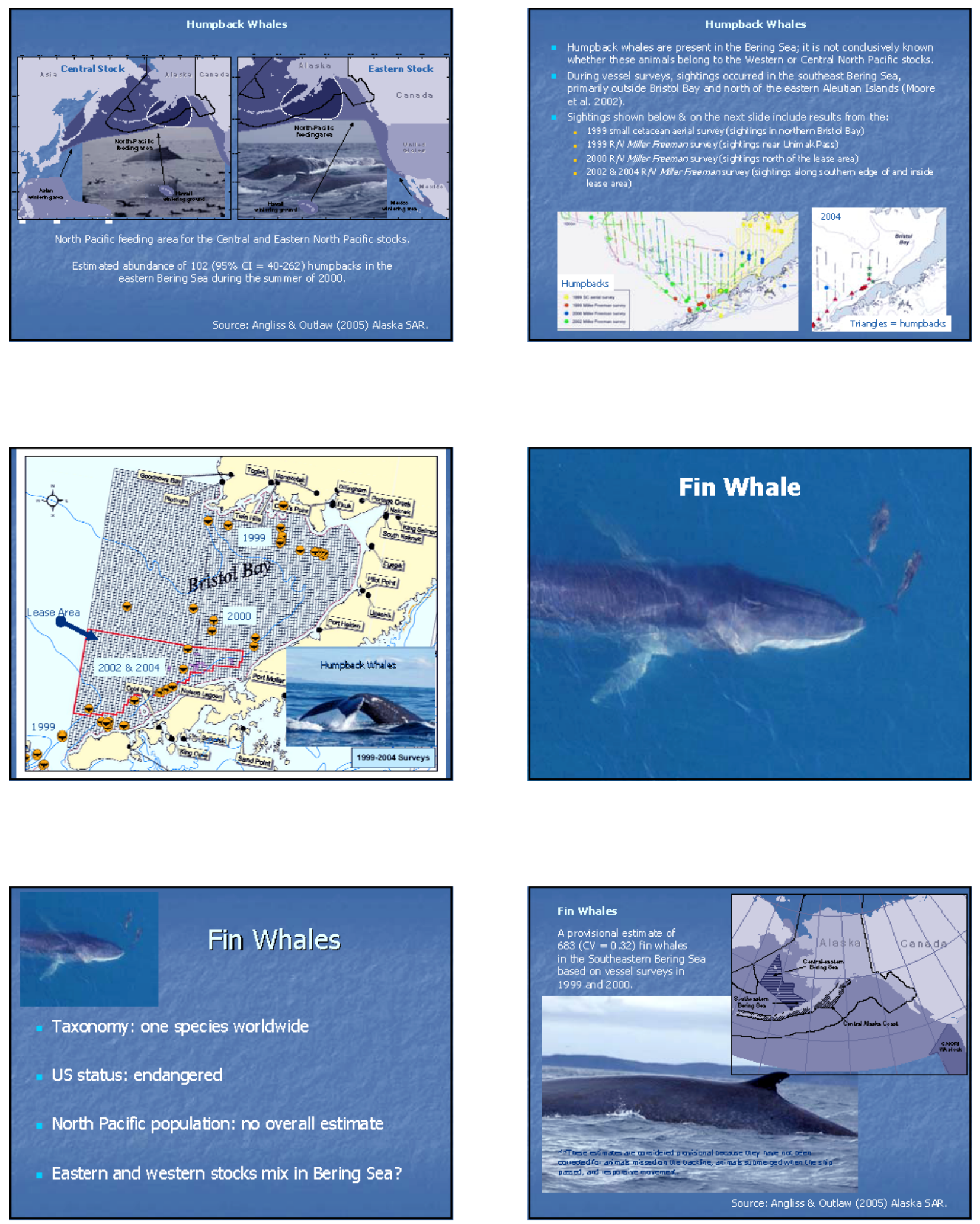

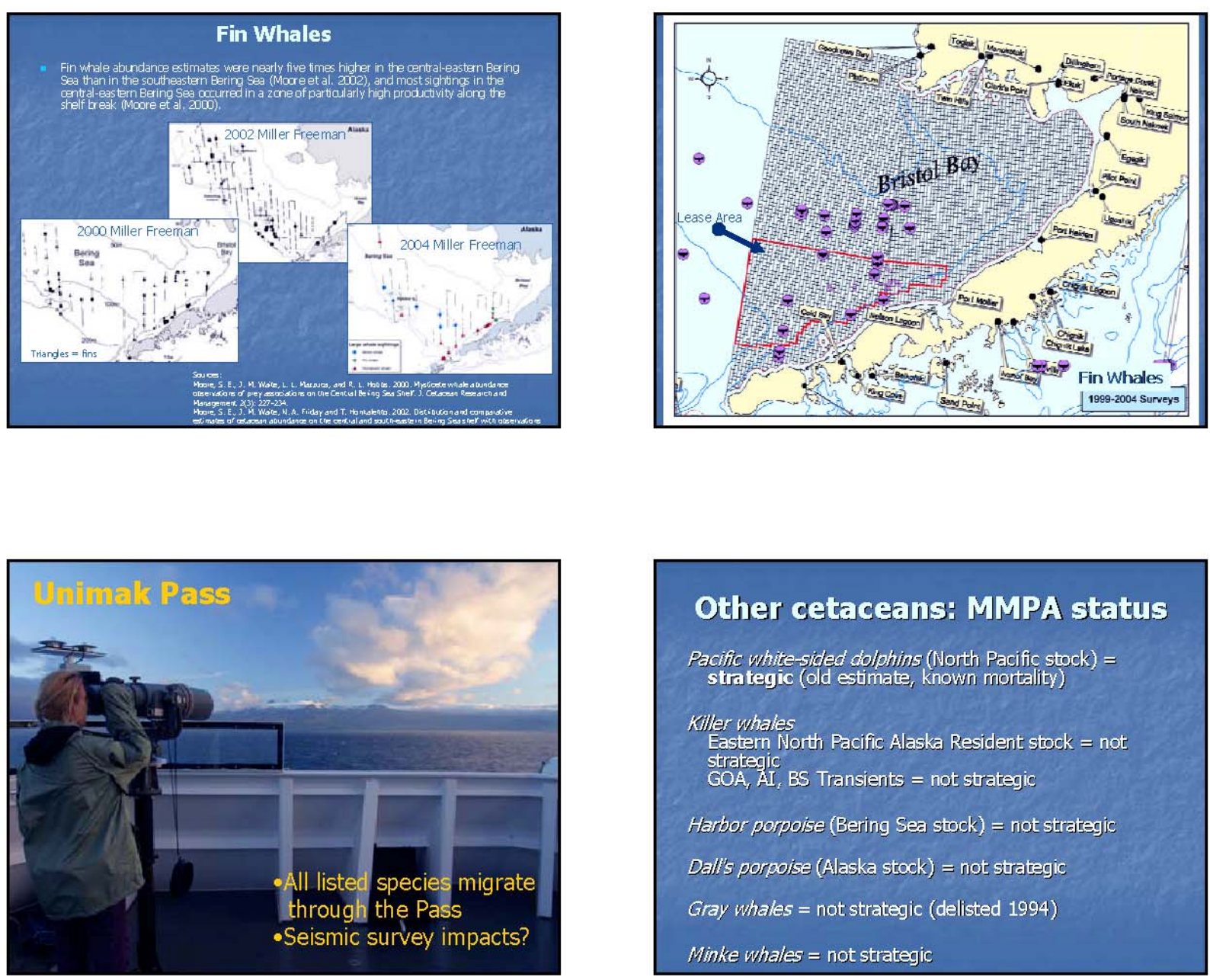

\section{Other cetaceans: MMPA status}

Pacific white-sided dolphins (North Pacific stock) = strategjo (old estimate, known mortality)

Killer whales

Eastern North Pacific Alaska Resident stock = not strategic

GOA, AI, BS Transients = not strategic

Herbor porpoise (Bering Sea stock $)=$ not strategic

Dalls porpoise $($ Alaska stock $)=$ not strategic

Gray whales $=$ not strategic (delisted 1994)

Minke whales $=$ not strategic
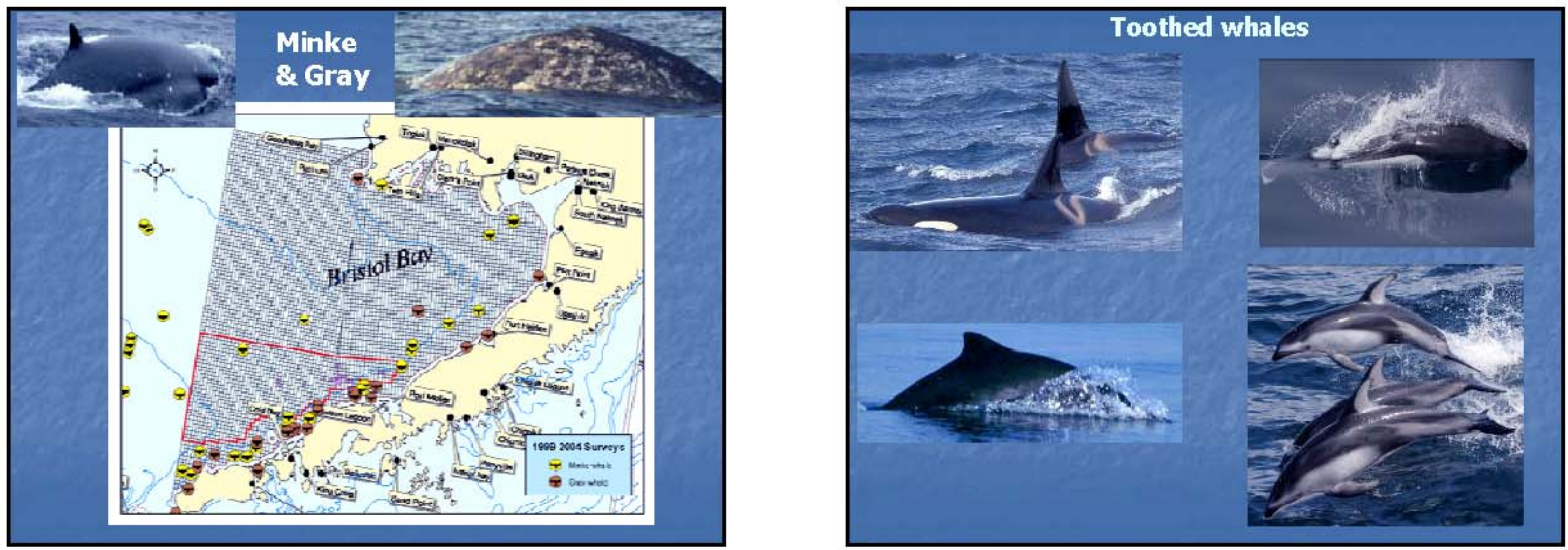

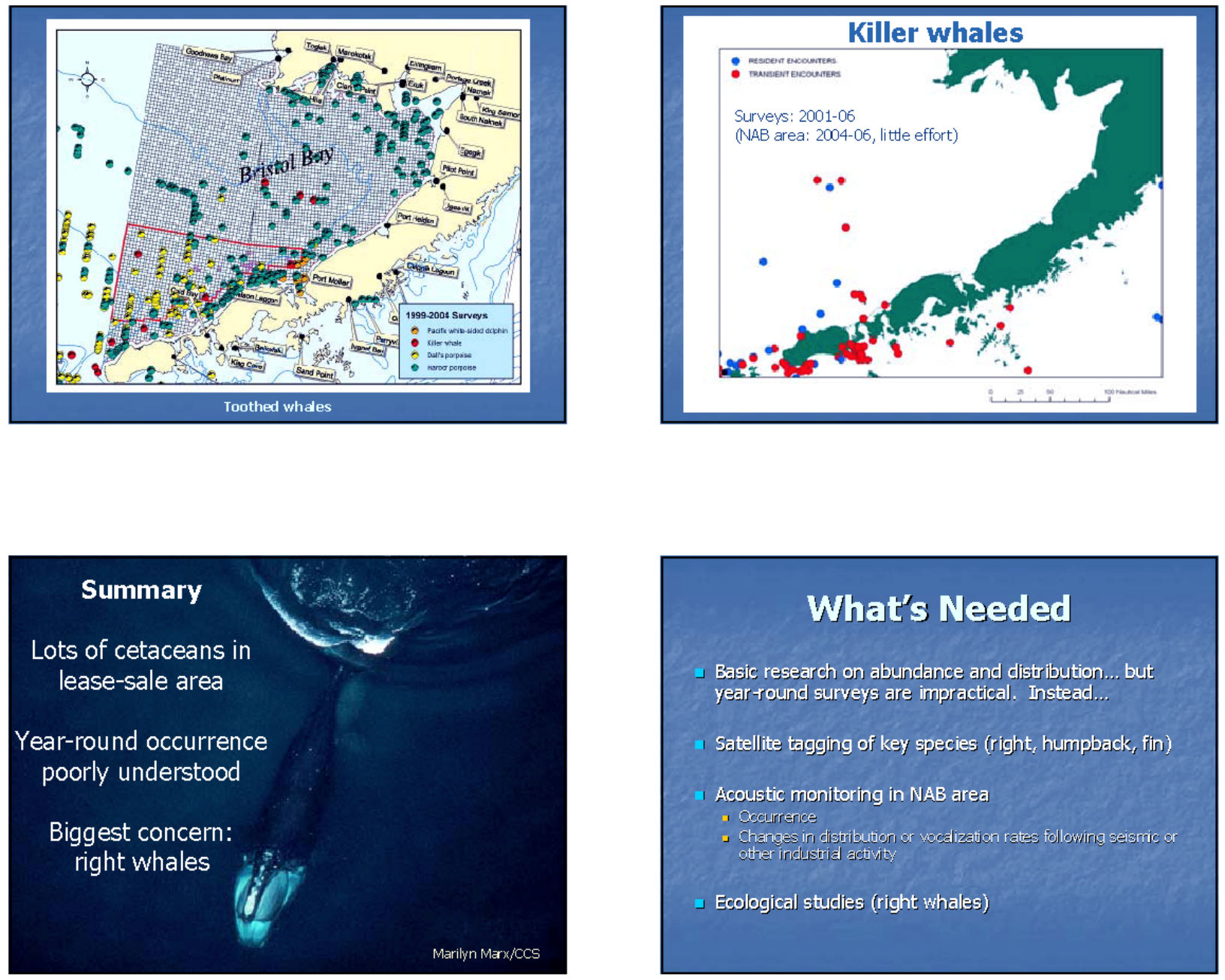

\section{What's Needed}

$\triangle$ Basic research on abundance and distribution... but year-round surveys are impractical. Instead.

I Satellite tagging of key species (right, humpback, fin)

I Acoustic monitoring in NAB area

- Cocurrence

- Changes in distribution or wocalization rates foll owing seismic or

other ingustria activt:

Ecological studles (right whales)

\section{Impact}

NAB contains right whale Critical Habitat and is a feeding ground for several species... and proposed areas of interest for industry likely occur in the migratory path.

Closely related bowhead whales are known to djyert from their migratory path at received sound levels of $120 \mathrm{~dB}$, which may occur $80 \mathrm{~km}$ from the seismic source.

Crifical to understand the responses of listed species during feeding and migratory behavior to better identify mitigation and monitoring required

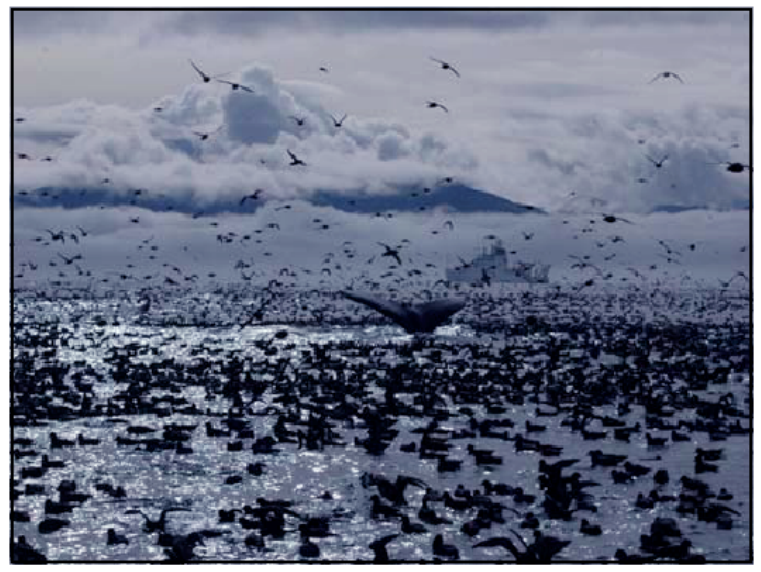



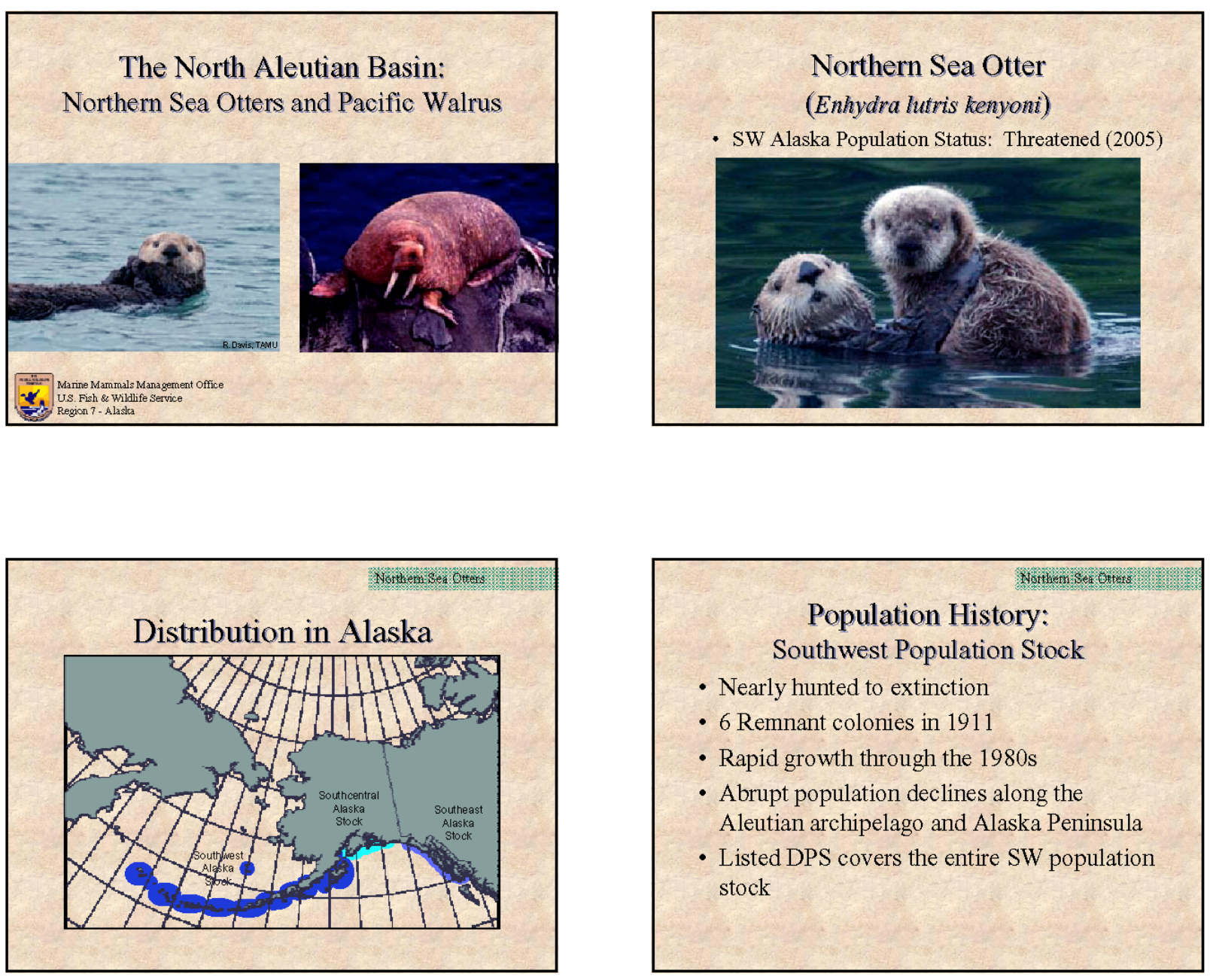

\section{Population History:}

Norttien Ser Grotor

Southwest Population Stock

- Nearly hunted to extinction

- 6 Remnant colonies in 1911

- Rapid growth through the 1980 s

- Abrupt population declines along the Aleutian archipelago and Alaska Peninsula

- Listed DPS covers the entire SW population stock
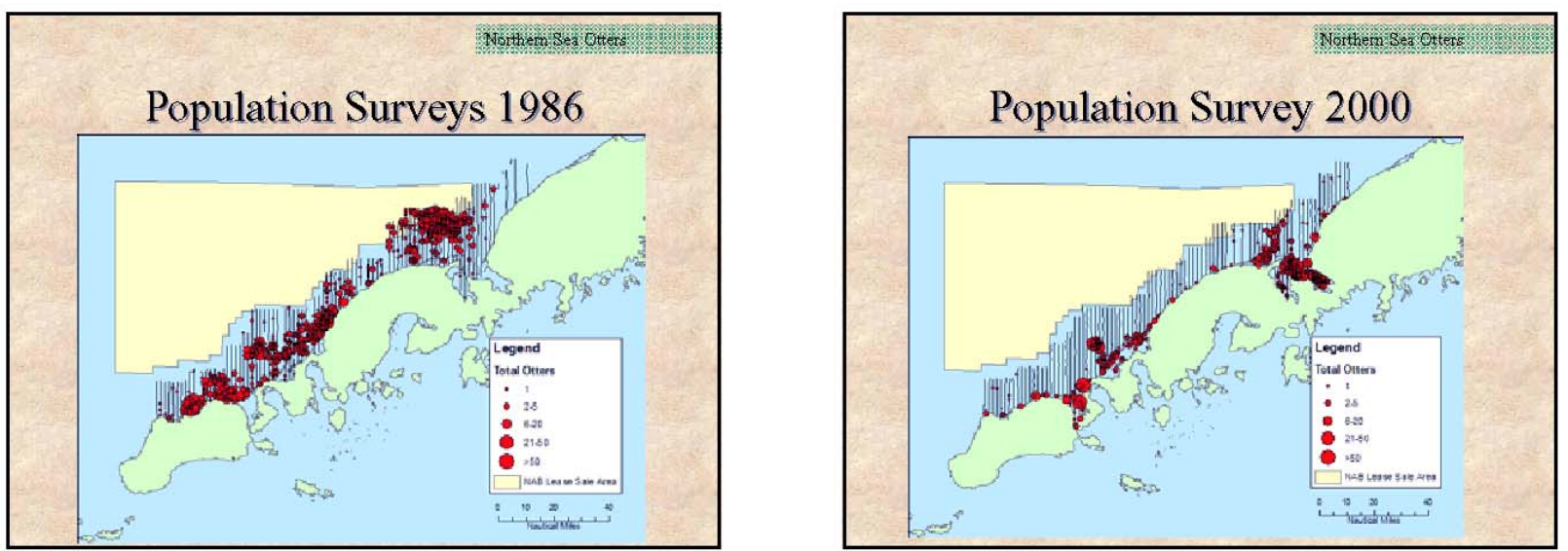


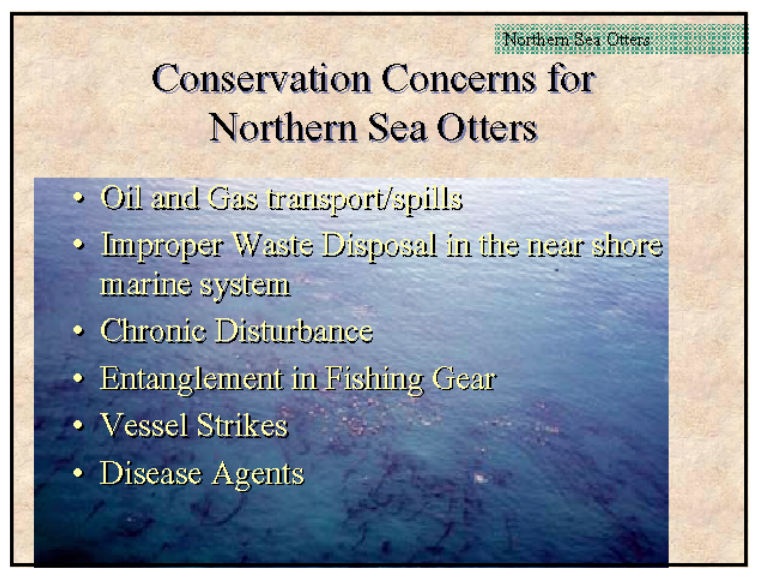

Nontien See Otris:

\section{Information Gaps:}

North Aleutian Basin Region

- Temporal Dynamics of the population - population trend

- Habitat Use

- seasonal/annual movement patterns

- evaluation of the prey base

- Health and Condition of the population

- body condition

- indices of health
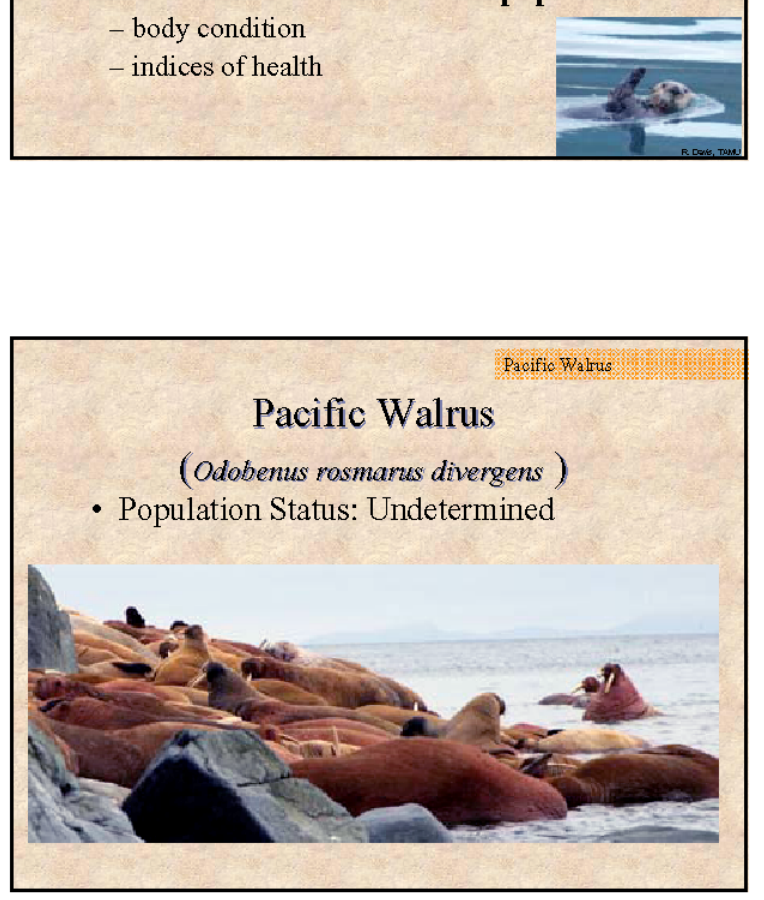

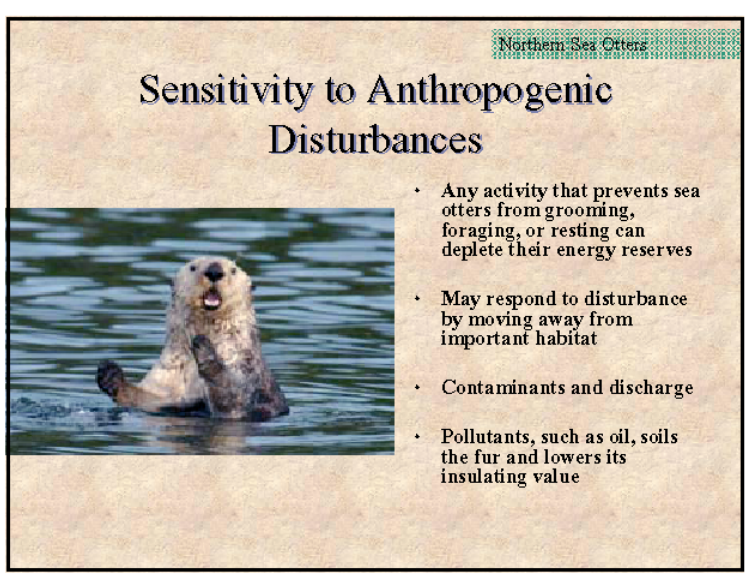

\section{Conservation and Management}

\section{Priorities}

- Population Surveys for Sea Otter Abundance and Distribution

- Systematic surveys of sea otters in the near shore and off shore habitats (10 yrs)

- Longitudinal Studies of Sea Otter Survival, Reproduction, and Movement

- radio telemetry studies to assess population demography

- Health and Condition Studies of Free Ranging Sea Otters

- Capture studies to assess health, condition, and potential disease agents

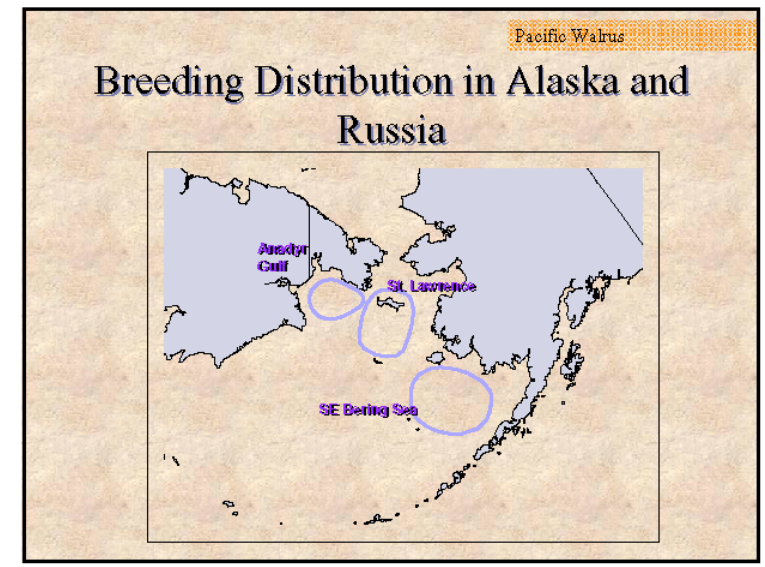



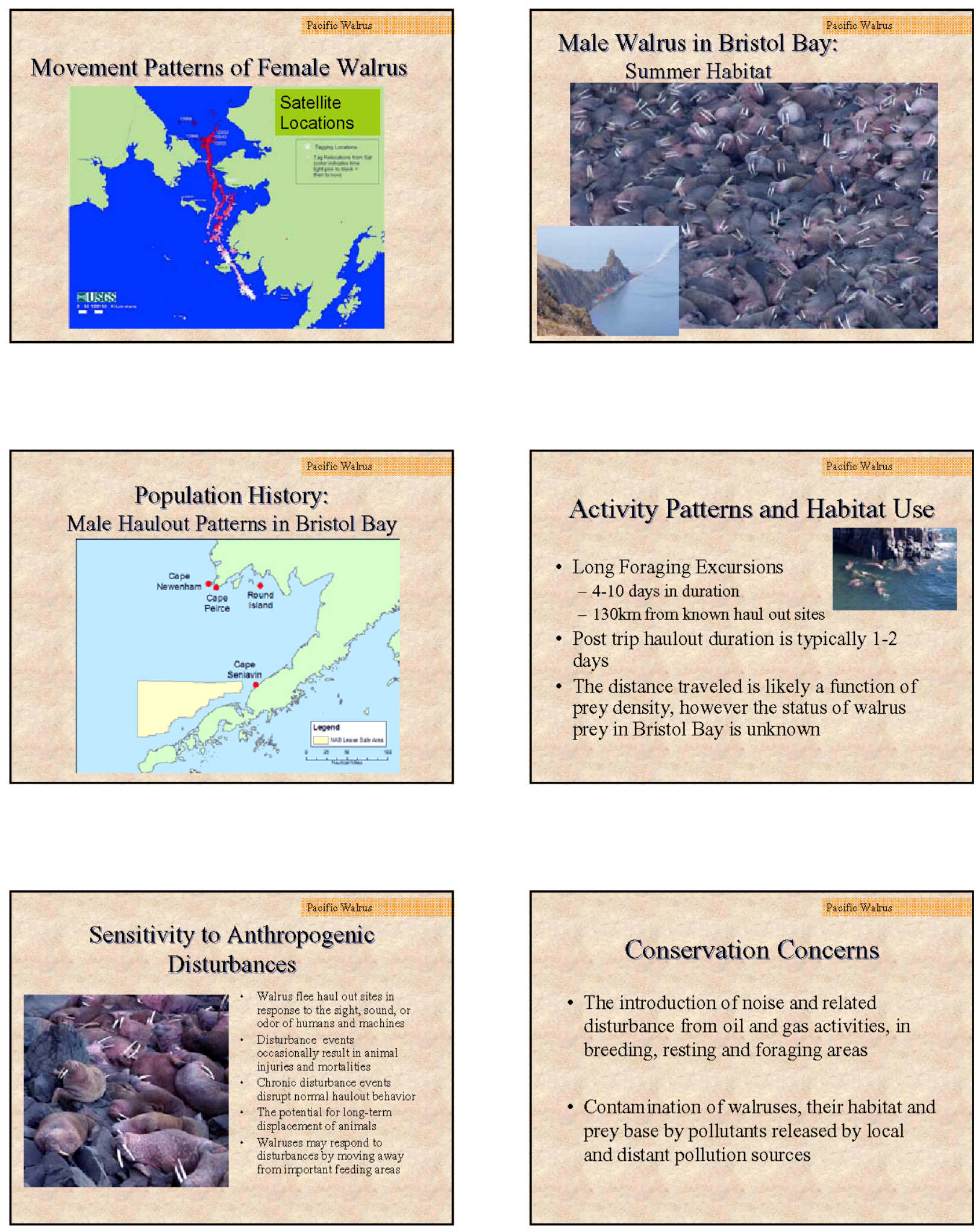


\section{Research and Monitoring Priorities}

- Habitat studies: Identify/delineate important foraging areas; Investigate seasonal distributions and haulout use patterns. Emphasis on the Cape Seniavin walrus haulout on the Alaska Peninsula

- Disturbance studies: Investigate responses to vessel/aircraft traffic and seismic operations

- Oil spill modeling: Oil spill trajectories, potential effects on walruses, prey species, and habitats 
APPENDIX C

STUDY PROFILES DEVELOPED AT THE NORTH ALEUTIAN BASIN INFORMATION STATUS AND RESEARCH PLANNING MEETING 


\section{C.1 OCEANOGRAPHY, ECOSYSTEMS, AND} FATE AND EFFECTS STUDY PROFILES 


\section{Proposed Study Profile}

Region: Alaska

Planning Area: $\quad$ North Aleutian Basin

Title: $\quad$ Modeling of Circulation

MMS Need for Information: Oil spill trajectory analysis for impact assessment on EIS. Physical data to support biological analysis.

\section{Period of Performance:}

- Phase 1: FY 2007-2008

- Phase 2: FY 2008-2011

\section{Description}

\section{Background}

Historic information is out of date, methodology and techniques have improved.

\section{Timing Needs} 2012.

Phase 1 needed for the EIS and before exploration. Phase 2 needed before the sale in

\section{Objectives}

1. Develop and improve an ocean circulation model that has demonstrated skill at representing the physical processes in the circulation within the domain.

2. Phase 1 adapt existing model for use in the oil spill trajectory analysis for the first North Aleutian Basin sale.

3. Phase 2 improve model to meet all objectives.

\section{Methods}

Develop numerical ocean model that includes sea ice processes, tides, eddies, coastal currents, emphasis on surface currents. Includes high-resolution bathymetry and atmospheric forcing. Includes hind-cast of 7- to 15-year period.

\section{Cost and Level of Effort}

- Phase 1: $\$ 300,000$

- Phase 2: $\$ 1$ to $\$ 3$ million

Date Information Is Required: 1.5 years before the North Aleutian Basin EISs. 


\section{Proposed Study Profile}

Region: Alaska

Planning Area: $\quad$ North Aleutian Basin

Title: $\quad$ Physical Oceanography Field Program

MMS Need for Information: Supporting data for the modeling effort. Data supporting biological studies. Environmental description for the EIS.

Period of Performance: FY 2008-2012

\section{Description}

\section{Background}

Insufficient knowledge of coastal flow, transport through Aleutian passes and lagoon exchanges. Insufficient knowledge of shelf-basin exchange, eddies, fronts, stratification, waves and wind forcing, tidal mixing.

\section{Timing Needs}

Post-lease.

\section{$\underline{\text { Objectives }}$}

1. Identify and describe critical dynamic processes potentially leading to improved parameterization for ocean modeling.

2. Advance the knowledge of coastal flow processes on the regional environment, including bays and lagoons.

3. Provide data to facilitate biological and ecosystem analyses.

4. Provide data for model verification and sensitivity testing.

\section{Methods}

1. Moorings and surface-layer drifters using the Argos GPS system.

2. Multiple, year-round moorings in the passes and across and along the coastal flow, plus one set on the Pacific side.

3. Current meters and pressure sensors at the entrances to lagoons.

4. Conduct three summer and two winter/spring hydrographic surveys.

5. Other instrumentation as appropriate.

\section{Cost and Level of Effort}

1. 12-14 moorings for coastal flow at $\$ 100,000$ each. 
2. 9-10 moorings for the passes at $\$ 100,000$ each.

3. Four current meters and pressure sensors at the entrances to lagoons at $\$ 50,000$ each.

4. 50 surface-layer drifters at $\$ 5,000$ each.

5. One day ship time for each mooring at $\$ 20,000$ per day

6. 40 days ship time for the hydrographic surveys at $\$ 20,000$ a day.

7. $\$ 500,000$ for data analysis and reporting.

Date Information Is Required: Post-lease. 


\section{Proposed Study Profile}

Region: Alaska

Planning Area: $\quad$ North Aleutian Basin

Title: $\quad$ Implementation of a Meteorological Buoy

MMS Need for Information: Required for meteorological and oceanographic modeling, and oil spill trajectory analysis and air quality impact assessment.

Period of Performance: FY 2008-2011

\section{Description}

Background

Buoys supports modeling methodology and techniques.

Timing Needs

In conjunction with meteorological modeling.

$\underline{\text { Objectives }}$

Meteorological data supports all modeling and oceanographic field programs.

\section{Methods}

In cooperation with National Oceanic and Atmospheric Administration National Data Buoy Center.

Cost and Level of Effort

Project cost: $\$ 250,000$ for the buoy plus $\$ 100,000$ per year.

Date Information Is Required: Parallel to the other field programs. 


\section{Proposed Study Profile}

Region: $\quad$ Alaska

Planning Area: $\quad$ North Aleutian Basin

Title: $\quad$ Mesoscale Meteorological Modeling

MMS Need for Information: Oil spill trajectory analysis and oceanographic modeling and air quality impact assessment.

Period of Performance: FY 2008-2011

Description

Background

Historic information lacks required detail; modeling methodology and techniques have improved.

Timing Needs

Leads circulation modeling by six months.

\section{Objectives}

Apply mesoscale meteorological model that has demonstrated skill at representing the physical processes within the domain.

\section{Methods}

Mesoscale meteorological model includes nesting or downscaling information from the larger domain to a high-resolution scale over the eastern Bering Sea. Includes high-resolution topography, radiative fluxes, and ocean thermal effects. Includes six hourly output from hindcast of 7- to 15-year period.

Cost and Level of Effort

Total project cost: $\$ 600,000$

Date Information Is Required: Two years before the North Aleutian Basin EISs. 


\section{Proposed Study Profile}

Region: $\quad$ Alaska

Planning Area: $\quad$ North Aleutian Basin

Title: $\quad$ Characterization of Sediments

MMS Need for Information: Provides baseline for monitoring and for assessing impacts of pollutants.

Period of Performance: FY 2007-2009

\section{Description}

\section{Background}

Historic information is out of date, methodology and techniques have improved.

$\underline{\text { Timing Needs }}$

Needed for the EIS and before exploration.

\section{$\underline{\text { Objectives }}$}

Identify and chemically characterize fine-grain sediments. Create statistically valid sampling design.

\section{Methods}

1. Polycyclic aromatic hydrocarbon characterization, standard suite of sediment characteristic, trace metals.

2. Quality control, interlaboratory calibration, and use of reference standards. Sediment coring.

\section{Cost and Level of Effort}

10 cores for dating, 3 cores for analysis and 50 surface sediment samples, including 25 for biota at the same location.

- Core Analysis: $10 /$ core $=100$ samples at $\$ 1,500$ per sample $=\$ 150,000$

- Biota: 50 samples at $\$ 1,000 /$ sample $=\$ 50,000$

- Ship Time: $\$ 25,000$ a day for 2 weeks $=\$ 350,000$

Date Information Is Required: Before the North Aleutian Basin EIS. 


\section{Proposed Study Profile}

Region: Alaska

Planning Area: $\quad$ North Aleutian Basin

Title: $\quad$ Characterization of Benthic Communities

MMS Need for Information: Provides baseline for monitoring; basis for assessing impacts, food web, higher trophic levels, and contaminant transfer.

Period of Performance: FY 2007-2009

\section{Description}

\section{Background}

Historic information is out of date, methodology and techniques have improved.

Timing Needs

Needed for the EIS and before exploration.

\section{Objectives}

1. Characterization of present benthic communities.

2. Statistically valid sampling design.

3. Identify primary food-web linkages to fisheries, birds, and marine mammals.

4. Link with oceanographic and biological characteristics.

\section{Methods}

Grab samples, box cores, and bottom trawls.

\section{Cost and Level of Effort}

Two years of field studies, two 2- to 3-week cruises. Cost not determined.

Date Information Is Required: Before the North Aleutian Basin EIS. 


\section{Proposed Study Profile}

Region: Alaska

Planning Area: $\quad$ North Aleutian Basin

Title: $\quad$ Sea Ice Edge Productivity

MMS Need for Information: Impact of oil spill on a keystone community.

Period of Performance: FY 2007-2009

\section{Description}

\section{Background}

Potential oil concentration area if a spill occurred during late winter and spring. This area is used by walrus, seals, and seabirds and supports high algal/plankton productivity.

\section{Timing Needs}

Needed for the lease-sale EIS.

\section{Objectives}

1. Assess the variability of primary production, and the contribution to secondary production in the ice front.

2. Determine the impacts of petroleum products on the community.

\section{Methods}

Ice cores, chlorophyll measurements, plankton samples, and primary productivity experiments. Shipboard laboratory experiments of contaminant effects. The hypothesis to be tested is that incorporation of oil in the sea ice is detrimental to sea ice primary productivity and associated food webs.

\section{Cost and Level of Effort}

One to two seasons of field studies. Cost not determined.

Date Information Is Required: Before the North Aleutian Basin EIS. 


\section{Proposed Study Profile}

Region: $\quad$ Alaska

Planning Area: $\quad$ North Aleutian Basin

Title: $\quad$ Identify and Characterize Eelgrass Communities

MMS Need for Information: Keystone habitats for fish, birds, mammals. Essential habitat for migratory birds, shorebirds, and waterfowl. Habitat of international significance. Baseline for impact assessment and monitoring.

Period of Performance: FY 2007-2009

\section{Description}

Background

Information on distribution and food web is incomplete and needs to be updated.

\section{Timing Needs}

Needed for the lease-sale EIS and before exploration.

\section{Objectives}

1. Identify the distribution of eelgrass communities.

2. Identify primary food-web linkages to fisheries, birds, and marine mammals.

3. Coordinate with coastal flow and tidal studies.

4. Link to the shore bird and waterfowl studies and subsistence studies.

5. Provide a basis for restoration planning.

\section{Methods}

1. Transect and quadrat surveys.

2. Genetic identification of subpopulations.

3. Isotope ratio studies of food webs.

4. Scuba surveys where necessary.

5. Seasonal studies integrated with waterfowl information.

\section{Cost and Level of Effort}

Two years of field studies. Cost not determined.

Date Information Is Required: Before the North Aleutian Basin EIS. 


\section{Proposed Study Profile}

Region: Alaska

Planning Area: $\quad$ North Aleutian Basin

Title: $\quad$ Intertidal Community Characterization

MMS Need for Information: Basis for assessing oil spill and construction impacts, food web, higher trophic levels, and contaminant transfer.

Period of Performance: FY 2007-2009

\section{Description}

\section{Background}

Little historic information is available. Potential area of high impact.

Timing Needs

Needed for the lease-sale EIS and before exploration.

\section{$\underline{\text { Objectives }}$}

1. Characterize present communities.

2. Identify primary food-web linkages to fisheries, birds, and marine mammals.

3. Include the intertidal zone of Amak Island and isolated rocky intertidal important for marine mammals and seabirds.

\section{Methods}

Quadrat samples, shoreline transects, visual and scuba surveys.

\section{Cost and Level of Effort}

Two years of field studies. Cost not determined.

Date Information Is Required: Before the North Aleutian Basin EIS. 


\section{C.2 SOCIOECONOMICS AND SUBSISTENCE STUDY PROFILES}




\section{Proposed Study Profile}

Region: Alaska

Planning Area: $\quad$ North Aleutian Basin

Title: $\quad$ North Aleutian Basin Socioeconomics Study, Phase I

MMS Need for Information: The information from this study will be used for NEPA analysis and documentation for the North Aleutian Basin prior to oil and gas exploration and development in that region.

Period of Performance: FY 2007-2009

\section{Description}

\section{Background}

The oil and gas industry has expressed interest in leasing part of the North Aleutian Basin to search for and possibly develop oil and gas deposits; this study would provide key socioeconomic baseline data. The Phase I effort would focus on the following communities and organizations: Nelson Lagoon, Sand Point, Cold Bay, False Pass, King Cove, Unalaska, Community Development Quota Groups, and the associated boroughs closest to proposed development.

\section{Timing Needs}

Data should be available for impact analysis prior to oil and gas exploration and development.

\section{Objectives}

1. Synthesize a broad range of existing socioeconomic data; for identified communities this information would include basic demographic data, basic data on the economic structure and activities in the region, assessment of labor base in the region (to evaluate local capacity to provide labor to the oil and gas industry, and educational and training requirements to obtain employment at various levels in the oil and gas industry).

2. Identify existing community infrastructure and public services, and capacity to incorporate change that likely would accompany oil and gas exploration and development.

3. Identify socioeconomic aspirations and values.

\section{Methods}

1. Conduct community consultations in all places included in Phase I, to ensure local interest in participation. 
2. Identify key sources of data: Census data, Aleutians East Borough, Aleut Corporation, Aleutian-Pribilof Islands Association, Eastern Aleutian Tribes, key communities, other pertinent boroughs, Community Development Quota groups, tribal governments, and village corporations.

3. Compile data and identify any key types of information that are unavailable from existing data sources.

4. Conduct focus groups for qualitative data collection and, as possible, obtain data unavailable from existing sources.

5. Conduct basic data analysis (baseline description) and prepare report describing the socioeconomic characteristics of the Phase I area.

6. Conduct community consultations to present data analysis and baseline description to the communities for their evaluation and comments.

7. Assess need for Phase II geographical or topical expansion - the nature of both potential expansions contingent on Phase I results.

\section{Cost and Level of Effort}

Total project cost: $\$ 500,000$

Date Information Is Required: Preliminary report by fall 2008. Final report by September 2009. 


\section{Proposed Study Profile}

Region: Alaska

Planning Area: $\quad$ North Aleutian Basin

Title: $\quad$ Subsistence Study for North Aleutian Basin

MMS Need for Information: Information will be used for National Environmental Policy Act (NEPA) analysis and documentation for North Aleutian Basin prior to oil and gas exploration and development in that region.

Period of Performance: FY 2007-2010

\section{Description}

Background

The oil and gas industry has expressed interest in leasing part of the North Aleutian Basin to search for, and possibly develop, oil and gas deposits; this study would provide key current subsistence baseline data. The subsistence study would include Nelson Lagoon, Cold Bay, False Pass, and three other settlements in the region as representative communities.

\section{Timing Needs}

Data will be collected and compiled as soon as possible.

\section{Objectives}

1. To gather current household and community data on subsistence activities - subsistence resources harvest, harvest levels of different resources, locations of subsistence activities for various resources, levels of participation for subsistence harvest and structure of resource exchange, timing for resource harvests.

2. For Nelson Lagoon, Cold Bay, False Pass, and three other representative settlements in the region, the data collected would include information on subsistence harvest and use similar to the standard data collected by the Alaska Department of Fish and Game, Division of Subsistence, using its standard survey tool and methods.

3. The subsistence survey would collect additional information on subsistence that would help to assess any potential impacts from oil and gas exploration and development. Such information would include household economic input into subsistence (particularly in the form of equipment), details on sharing subsistence harvest among members of a community, enhanced information on the timing of subsistence harvests for various resources, traditional knowledge data (particularly on the locations and populations of subsistence resources), map data that includes information on relative importance of various locations to subsistence harvests, and information on the subsistence cycle with respect to wage employment. 


\section{Methods}

1. Conduct community consultations in all places from which data were collected, to ensure local interest in participation and accuracy of the information obtained.

2. Conduct an Alaska Department of Fish and Game subsistence survey, modified as necessary to obtain the additional information described above under Objectives.

3. Integrate as appropriate revised biological data on subsistence resources.

4. Compile data from the survey.

5. Conduct basic data analysis (baseline description) and prepare report describing the subsistence activities in each of the target communities.

6. Conduct community consultations to present data analysis/baseline description to the communities for their evaluation and comments.

Cost and Level of Effort

Total project cost: $\$ 350,000$

Date Information Is Required: Final report is needed by spring 2010. 


\section{C.3 FISH AND FISHERIES STUDY PROFILES}




\section{Proposed Study Profile}

Region: $\quad$ Alaska

Planning Area: $\quad$ North Aleutian Basin

Title: $\quad$ North Aleutian Basin Nearshore Forage Fish Seasonal Distribution and Spawning Survey

MMS Need for Information: Forage fish are an important component of the North Aleutian Basin ecosystem, primarily as prey to marine mammals, seabirds, and commercially important fish species. Study information will be used to prepare an EIS in 2010.

Period of Performance: FY 2007-2009

\section{Description}

\section{Background}

The southeast Bering Sea is a data-rich location for marine fish distribution and abundance information. Similar information is lacking, however, for shallow nearshore waters along most of the Alaska Peninsula. Shallow nearshore waters ( $<5 \mathrm{~m}$ deep and $<20 \mathrm{~m}$ offshore) are some of most productive habitats in Alaska and many Fishery Management Plan species use nearshore habitats at some point in their life cycle. Alaska has more than $50 \%$ of the U.S. coastline; most is pristine, but all of it is vulnerable to changing environmental perturbations and increasing stress from shoreline development. In particular, information is needed on the function and use of nearshore habitats by most forage species (e.g., capelin, Pacific sand lance, Pacific sandfish) because of their importance as a prey resource for higher-level-trophic consumers (e.g., marine mammals, fish), and the susceptibility of nearshore spawning and rearing areas to disturbance from oil and other shoreline development. Exxon Valdez oil spill studies have demonstrated that oil impacts are greatest in the nearshore zone, and that oil persists in this zone for decades. This is a high-priority habitat to assess species presence, seasonality, and vulnerability.

Standard research surveys by the Alaska Fisheries Science Center in the Bering Sea sample all habitats except the nearshore, and the standard surveys do not target forage fish. This project will assess the seasonal distribution, habitat use, relative abundance, diet, and energy density of forage fish in the nearshore ecosystem of the North Aleutian Basin. Because nearshore habitats are vulnerable to human disturbance, a better understanding of how the nearshore environment supports ecologically important forage fish species is needed to help managers conserve forage fish populations and protect essential habitats. We know that several forage fish species use the nearshore environment, but we do not fully understand their dependence and fidelity to the different habitats types within the nearshore, or which habitats are more important for different life stages. Seasonal changes in the use of nearshore habitats or energetics of forage fish are also not known. 


\section{$\underline{\text { Objectives }}$}

This study will help address information gaps on forage fish in the North Aleutian Basin by assessing:

1. Seasonal use of nearshore habitats,

2. Relative fish abundance in different habitat type, and

3. Energy flux and relative growth of forage fishes in different seasons.

\section{Methods}

1. Conduct a seasonal fish use and habitat assessment study in the North Aleutian Basin. Nearshore fishes will be sampled in spring, summer, and fall with a variety of gear types (e.g., beach seine, small boat trawling, purse seine, jigging, remotely operated vehicle). Sampling will be in nearshore waters in a variety of habitat types (e.g., sand/gravel beaches, eelgrass), as well as the shallow nearshore areas down to $20 \mathrm{~m}$. At each sampling site, we will measure habitat characteristics following ShoreZone groundtruthing protocols. Because nearshore seasonal fish use can be difficult to assess, especially in remote locations in winter, we will review new technology such as using an in-situ underwater camera that intermittently takes pictures and would allow assessment of fish habitat use.

2. All fish captured will be identified and counted, and a subsample of individuals will be measured for fork length. For the primary forage fish species, including capelin, Pacific herring, Pacific sand lance, and Pacific sandfish, additional sampling will include collection of otoliths, stomachs, and whole fish.

3. Several assessments will be made on the status of the fish, including age, diet, and energetics analyses. The seasonal sampling (fall, spring) are critical time periods for the energetics assessments. Young fish with inadequate energy reserves going into the winter have poor survival potential. These data for the forage fish species as well as the top predators are critical to modelers

4. All data will be added to an existing database. This database will be linked into the Alaska ShoreZone/Fish Atlas ArcIMS Web site hosted by the NMFS, Alaska Regional Office. This website will be dynamic and will be continually updated as more data become available. The Web site contains detailed information throughout Alaska on shoreline geomorphology (substrate, slope, etc.), fish use by habitat type, other biological characteristics (taxonomic lists, rare species, etc.), and digital images for documentation. MMS scientists and managers will be able to query the database to obtain site-specific information on habitat type and associated fish assemblages in the Basin and in the Beaufort and Chukchi Seas.

\section{Cost and Level of Effort}

Total project cost: $\$ 300,000$, including $\$ 90,000$ for vessel and $\$ 150,000$ for aerial survey platform. 
Date Information Is Required: Study results will be used in EIS preparation in 2010. The study design review will be due July 2007. Fieldwork will be completed in FY 2008-2009, and results reported in late 2009. 


\section{Proposed Study Profile}

Region: Alaska

Planning Area: $\quad$ North Aleutian Basin

Title: $\quad$ Seasonal Distribution and Condition of Juvenile Pacific Salmon and Young of the Year Pollock within the North Aleutian Basin

MMS Need for Information: Pacific salmon and forage fish are an important component of the North Aleutian Basin ecosystem, primarily as prey to marine mammals, seabirds, and commercially important fish species. Study information will be used to prepare an EIS in 2010.

Period of Performance: FY 2008-2010

\section{Description}

\section{Background}

The southeast Bering Sea is a data-rich location for marine fish distribution, abundance, and condition information. Similar information is lacking, however, for epipelagic communities within nearshore waters along the Alaska Peninsula. In particular, information is needed on the function and use of nearshore habitats by most forage species (e.g., juvenile salmon, capelin, Pacific sand lance, Pacific sandfish, and Pacific herring) because of their importance as a prey resource for higher-level-trophic consumers (e.g., marine mammals, fish), and the susceptibility of nearshore spawning and rearing areas to disturbance from human activities.

We know that juvenile salmon experience high marine mortality rates during the first year at sea and that size of the fish plays an important role, with larger fish having higher marine survival rates. Size-dependent mortality of juvenile salmon is believed to be concentrated during two marine life history stages. The first stage occurs just after juvenile salmon enter the marine environment, where smaller individuals are believed to experience higher size-selective predation. The second stage occurs following the first summer at sea, when smaller individuals may not have sufficient energy reserves to survive late fall and winter.

Standard research surveys by the Alaska Fisheries Science Center's Ocean Carrying Capacity Program in the Bering Sea sample the epipelagic fish communities within the North Aleutian Basin from nearshore and offshore habitats during late summer and early fall. The annual surveys (2000-2006) have provided much needed data for our understanding of how ocean conditions affect growth and marine survival of Pacific salmon after their first summer at sea. However, our understanding of the processes that affect marine survival of juvenile salmon during their first few months at sea is limited, especially for western Alaska salmon stocks.

We propose to use a similar grid sampling system within Bristol Bay and along the Alaska Peninsula during July to add a seasonal component to our research. A similar survey during July 1999 indicated that sockeye, chinook, coho, pink, and chum salmon from Bristol Bay watersheds and several forage fish species (i.e., capelin, sand lance, sandfish, and rainbow smelt) 
use the nearshore environment of Bristol Bay and the Alaska Peninsula. An earlier study during the late 1960s also indicated that juvenile Bristol Bay sockeye salmon utilized these environments during their first few months at sea. This project will assess the seasonality (summer, fall), distribution, relative abundance, diet, energy density, size, and potential predators of juvenile salmon and other forage fish in the nearshore ecosystem ( $>20 \mathrm{~m}$ to $100 \mathrm{~m}$ ) of the North Aleutian Basin. This information is lacking because salmon and other forage fish species are usually not targeted for assessment, and nearshore areas are seldom surveyed as fish habitat. Because nearshore habitats are vulnerable to human disturbance, a better understanding of how the nearshore environment supports ecologically important juvenile salmon and other forage fish species is needed to help managers conserve these populations and protect essential habitats. In addition, we do not know the effect of season on the utilization of nearshore habitats or energetics of salmon and forage fish during summer.

\section{Objectives}

This study will help address information gaps on forage fish in the Basin by assessing:

1. Seasonal (summer and fall) use of nearshore habitats ( $>20 \mathrm{~m}$ to $100 \mathrm{~m}$ ).

2. Relative fish abundance by habitat type.

3. Energy flux and relative growth of salmon and forage fishes through seasonal change.

\section{Methods}

1. Conduct a seasonal fish use and habitat assessment study in the North Aleutian Basin. Nearshore fishes will be sampled in July (summer) and again in our annual surveys in August and September (fall) with a surface trawl (top $15 \mathrm{~m}$ of the water column). Sampling will be in waters $20 \mathrm{~m}$ deep or greater. At each sampling site, we will measure physical and biological oceanographic characteristics and biological characteristics of salmon and forage fish species.

2. All fish captured will be identified and counted and a subsample of individuals will be measured for fork length. Several assessments will be made on the status of the fish, including age, diet, and energetic analyses. The seasonal sampling (summer, fall) are critical time periods for the energetic and growth assessments. Young fish with inadequate energy reserves going into the winter have poor survival potential. These data are of critical importance to modelers.

3. Archive environmental data and specimens to provide a cost-effective means of future hypothesis testing by MMS and other agencies.

\section{Cost and Level of Effort}

Total cost: $\$ 600,000$, including $\$ 350,000$ for a vessel

Date Information Is Required: Study results will be used in EIS preparation in 2010. The study design review will be due July 2007. Fieldwork will be completed in FY 2008-2009, and results reported in late 2009. 


\section{Proposed Study Profile}

Region: Alaska

Planning Area: $\quad$ North Aleutian Basin

Title: $\quad$ North Aleutian Basin Ichthyoplankton and Zooplankton Monitoring

MMS Need for Information: Zooplankton and larval fishes are important to energy transfer and recruitment dynamics of commercially important species in the Eastern Bering Sea ecosystem. Baseline data on fish larvae and zooplankton abundance and distribution along the North Aleutian Basin are necessary to understand coupling between biological and physical variables, and energy linkages between lower and higher trophic levels. These data will be invaluable to the MMS in determining damage to the environment in the event of an oil spill or leak. In addition, the data provided from this study could also be used to evaluate the potential impacts of drilling structures. Study information will be used in NEPA analysis and documentation for Bristol Bay lease sales and development and production plans.

Period of Performance: FY 2007-2010

\section{Description}

\section{Background}

Lower-trophic-level production is critical to energy transfer through food webs. Larval fish survival is often a recruitment bottleneck for commercial species. Information on lowertrophic-level dynamics in the North Aleutian Basin is needed to understand present conditions and to serve as a baseline to assess potential impacts of oil and gas development on Bering Sea marine species. The North Aleutian Basin and Bristol Bay are among the world's most productive ecosystems, so understanding zooplankton (diversity, distribution, production) and ichthyoplankton (diversity, growth, survival, recruitment) dynamics is fundamental to understanding and assessing repercussions at higher trophic levels. This type of fundamental information is critical to accurate and successful assessment of potential affects of oil and gas development in this region. Vertebrate and invertebrate species that spend all or parts of their life histories in the near surface could be highly vulnerable to the impacts of oil leaks or spills, and improved information on the ecology of these species will be invaluable to assessing impacts of oil and gas development. Fish eggs, especially for walleye pollock and flatfishes, may be particularly vulnerable.

The NOAA Eco-FOCI Program currently conducts research in the North Aleutian Basin, along the Alaska Peninsula from Unimak Island to Bristol Bay (offshore of the $50 \mathrm{~m}$ isobath). We propose to expand our surveys in 2008 in spring (May) and autumn (September) to include Bristol Bay inshore of the $50 \mathrm{~m}$ isobath. This will provide new information on current conditions on the Bering Sea Inner Shelf, and will provide much-needed information on seasonality of production. In addition, we will collaborate with Eco-FOCI physical oceanographers at the NOAA Pacific Marine Environmental Laboratory, who can incorporate the distribution and life history information into oceanographic models of transport. We would also work with another 
NOAA program, BASIS, (Bering Aleutian Salmon International Survey) that samples the Bristol Bay area in the summer (August 2008) to identify the larval fishes collected during their survey and incorporate the data into the project.

\section{$\underline{\text { Objectives }}$}

1. Extend two existing NMFS surveys to include zooplankton and ichthyoplankton sampling in Bristol Bay inshore of the $50 \mathrm{~m}$ isobath in 2008 (May, September). Collaborate to analyze ichthyoplankton samples from BASIS collections made in August 2008. Assess ichthyoplankton and zooplankton diversity, distribution, and abundance along the North Aleutian Basin and in Bristol Bay to allow assessment of future changes in the planktonic community.

2. Evaluate vertical and horizontal abundance and size distribution of eggs and larvae of several key economic and ecologically important species, including walleye pollock, Pacific cod, northern rock sole (Lepidopsetta polyxystra), and capelin (Mallotus villosus).

3. Document the vertical and horizontal patterns of abundance of marine zooplankton, particularly those species and life history stages that are most important for the recruitment dynamics of commercially valuable fish species.

4. Evaluate species composition and assemblage structure of ichthyoplankton and zooplankton assemblages in Bristol Bay.

5. Relate observed patterns to predominant physical oceanographic conditions.

\section{Methods}

1. Design a series of stations in Bristol Bay on a fixed grid. Conduct neuston, depthdiscrete, and oblique sampling for zooplankton and ichthyoplankton in May and September 2008.

2. Send samples to the Plankton Sorting and Identification Center (ZSIOP) in Szczecin, Poland. Eco-FOCI has a 30-year history of joint cooperation and taxonomic expertise with ZSIOP. Verify sorts at the AFSC in Seattle and archive specimens at the University of Washington Fish Collection, where we have a long-term commitment to store and access our samples. Summarize information on fish distribution, relative abundance, locations and times of critical or sensitive life history stage habitats, and trophic structure in GIS and report format. Provide results for NEPA analyses.

3. For the primary ichthyoplankton and zooplankton species, summarize vertical and horizontal distribution and relate patterns to environmental variables.

4. Archive biological and environmental data and specimens to provide a cost-effective means of future hypothesis testing by MMS and other agencies.

\section{Cost and Level of Effort}

Total project cost: $\$ 300,000$

Date Information Is Required: Study information will be used in NEPA analysis and documentation for potential North Aleutian Basin lease sales and development and production 
plans. The surveys will be implemented in 2008, and final survey results will be due July 2010 . Draft and final reports will be due October and December 2010, respectively. 


\section{Proposed Study Profile}

Region: Alaska

Planning Area: $\quad$ North Aleutian Basin

Title: $\quad$ Compile Historical Information about Seismic Surveys and Fishery Information in the North Aleutian Basin

MMS Need for Information: Information would be used in NEPA evaluations to evaluate whether seismic surveys within the Sale 92 Area of the North Aleutian Basin would affect commercial fishery catches.

Period of Performance: FY 2007

\section{Description}

Background

Data are available on locations and timing of seismic surveys conducted within the North Aleutian Basin. It may be possible to use these data to quantify the effect of seismic surveys on fishery catch. There may be some difficulties in making inferences from these kinds of data, but attempts will be made to control for the effects of confounding variables.

Timing Needs

This evaluation would be a high priority for consideration for deferral areas prior to the lease-sale EIS.

\section{Objectives}

Evaluate whether there is evidence that seismic surveys within the Sale 92 Area of the North Aleutian Basin would affect commercial fishery catches.

\section{Methods}

1. Overlay historic seismic data for Sale 92 Area with available catch-per-unit effort from same time and place.

2. Look at seismic effects studies for similar fish species (e.g., Engas on cod).

\section{Cost and Level of Effort}

One-month literature review, 3 months analyst effort for fishery data, 2 months of analysis, 3 months for seismic data collation. This would be a relatively low-cost, rapid assessment.

Date Information Is Required: Prior to lease-sale EIS. 


\section{Proposed Study Profile}

Region: Alaska

Planning Area: $\quad$ North Aleutian Basin

Title: $\quad$ Evaluation of Potential for Space-Use Conflicts between Fishery Activities and Oil and Gas Development Activities within the Sale 92 Area

MMS Need for Information: Information would be used in NEPA evaluations to evaluate whether oil and gas development within the Sale 92 Area of the North Aleutian Basin would affect commercial fishery catches.

Period of Performance: FY 2007

\section{Description}

\section{Background}

Data are available from NMFS on commercial fishery catches in the North Aleutian Basin. These data include information on locations of catches, species, and gear types used. It may be possible to use these data to quantify potential conflicts between oil and gas development and commercial fisheries.

\section{Timing Needs}

This evaluation would be a high priority for consideration for deferral areas prior to lease-sale EIS.

\section{$\underline{\text { Objectives }}$}

Identify potential conflicts between development and commercial fisheries within the Sale 92 Area of the North Aleutian Basin.

\section{Methods}

Map the historic distribution of fishery catch data (catch per unit effort, species, numbers, gear type) in the Sale 92 Area.

\section{Cost and Level of Effort}

One month literature review, 3 months analyst effort for fishery data, 2 months of analysis, 3 months for data collation. This would be a relatively low-cost, rapid assessment.

Date Information Is Required: Prior to lease-sale EIS. 


\section{Proposed Study Profile}

Region: $\quad$ Alaska

Planning Area: $\quad$ North Aleutian Basin

Title: $\quad$ Nearshore Distribution of Juvenile Flatfishes in the Eastern Bering Sea

MMS Need for Information: The Eastern Bering Sea shelf is home to a group of flatfish species that are found in large abundance and are important in the Bering Sea ecosystem and to the coastal communities. The timing and distribution patterns of the juvenile flatfish settlement is directly related to annual recruitment success and is influenced by large-scale pressure fields and local seasonal hydrography. The proposed study will verify the cross-shelf flow mechanism and the role of the formation of the inner front in the settlement of juvenile flatfish and would allow researchers to differentiate shifts in flatfish productions caused by habitat disturbance, density dependence, or temporal shifts in climate forcing. Study information will be used in NEPA analyses and documentation for North Aleutian Basin lease sales and for development and production plans.

Period of Performance: FY 2007-2009

\section{Description}

\section{Background}

Knowledge of the distribution and settlement patterns of juvenile flatfish is required to evaluate the potential environmental impacts of oil and gas development in the Eastern Bering Sea. Retrospective analysis of spring pressure fields in the Eastern Bering Sea revealed that a decadal shift in cross-shelf wind patterns occurred in 1977 and 1989, and perhaps again in 2000. Retrospective analyses of crab and flatfish stocks in the region suggest that these shifts in crossshelf winds may influence the advection of flatfish larvae to suitable nursery areas. A feasibility study was conducted in the eastern Bering Sea in August 2003 to determine whether ages 0 and 1 flatfish could be captured in nearshore areas with a small beam trawl and to obtain physical data on the location and structure of the inner front and sediment grain size. The cruise was successful in accomplishing the stated objectives, but was limited in time and space due to its exploratory nature.

This study would expand the beam trawl survey of the coastal and middle domains on both sides of the inner front in the northern Bristol Bay area. The size and quality of the inner front would be determined and sediment collected to assess which processes are critical to density dependent effects on recruitment success and which are the result of large-scale oceanographic effects.

\section{Objectives}

1. Determine the distribution and abundance of juvenile flatfish (and crab) species relative to the inner front of northern Bristol Bay. 
2. Obtain physical data on the location and structure of the inner front and collect sediment samples to determine the structure of the sediment in the nursery area relative to depth, fish abundance, and the location of the inner front.

\section{Methods}

1. Perform a two-week juvenile flatfish survey of the northern Bristol Bay area using the plumbstaff beam trawl, conductivity-temperature-depth casts, and sediment grabs.

2. Analyze the data in conjunction with hydrographic current models and stock assessment recruitment estimates of juvenile flatfish.

\section{Cost and Level of Effort}

Total cost: $\$ 360,000$, including $\$ 250,000$ for a vessel

Date Information Is Required: Study information will be used in NEPA analyses and documentation for North Aleutian Basin lease sales and for development and production plans. The survey would be conducted in August 2007. Hydrographic model applications and data analysis should be completed by December 2009. 


\section{Proposed Study Profile}

Region: Alaska

Planning Area: $\quad$ North Aleutian Basin

Title: $\quad$ North Aleutian Basin Fishing Communities

MMS Need for Information: This study will allow MMS to understand connections between specific fishing grounds in the North Aleutian Basin and human fishing communities on shore. It is necessary to understand these connections in order to analyze potential social impacts (per NEPA) on the human environment of leasing activity in different ocean areas and to improve social and economic aspects of oil spill risk assessment.

Period of Performance: FY 2007-2010

\section{Description}

\section{Background}

The North Aleutian Basin has some of the world's riches fishing grounds, which have provided enormous social and economic benefits to fishing communities in Alaska and other states. Many communities in the region are highly dependent on commercial fishing as the major economic activity currently available. The potential for oil and gas development leases in marine locations in the region creates the need for assessment of potential impacts on these communities. In addition to socioeconomic impacts created by shore-based activities, socioeconomic impacts may occur from effects to ocean fishing grounds from closed fishing areas, reduced harvest, or other impacts to catch.

Commercial fishing patterns indicate that fish harvested from certain ocean locations are likely to be landed for processing in a given community. Fish harvested from other locations are likely to be landed elsewhere. Thus, communities will have different risk and impact profiles under different development scenarios. To understand the different risks and vulnerabilities of specific communities, it is necessary to understand which ocean areas they rely on. This study will use geographic information system (GIS) analysis to link communities to particular ocean areas through commercial fishing patterns, enabling a detailed assessment of potential impacts.

The information required for this study already exists in state and federal records. No new primary data will need to be collected. Catch location is recorded as ADFG statistical areas (about 10 square miles) on fish tickets, along with landing information (port codes). By connecting these data in a GIS, we can map which areas of the ocean typically produce fish for which fishing communities. The study will produce a quantitative assessment of potential impacts on communities that receive fish landings from areas already identified as potential lease sites.

The study will also produce an interactive tool which can be used to assess potential impacts on different communities under other leasing scenarios and various oil spill scenarios. 
The end user will be able to click on an area or areas of the ocean and the tool will return information on how many fish (by species and season) caught in those areas were received by which ports. Ex-vessel fish prices will be used to translate this information into the value of these fish per community. When combined with oil spill trajectory models or with localized lease impact models (which can be used to determine which ocean areas to select), the tool will predict which communities will be most affected under a specific scenario. In the event of an actual oil spill, the tool can also provide a rapid assessment of the most economically vulnerable communities.

The methods behind this type of analysis have been pioneered by geographer Kevin St. Martin at Rutgers University for use in socioeconomic analysis for fisheries management plans and have been applied in a limited manner to the study of some West Coast fisheries. They have not yet been applied in Alaska.

\section{$\underline{\text { Objectives }}$}

The objectives of this study are to provide a GIS tool that can be used to:

1. Analyze the potential socioeconomic impacts of different leasing scenarios on fishing communities.

2. Quickly assess the fishing communities most vulnerable to impacts in the aftermath of an oil spill (as mediated through closed fishing grounds or other effects).

3. Provide a basis in quantitative data for the distribution of mitigation efforts to the fishing communities most likely to be affected.

\section{Methods}

1. Data: ADFG statistical areas (catch) and ports codes (landings) as extracted from ADFG fish tickets and other existing records.

2. Geographic scope: Marine areas and ports of the North Aleutian Basin.

3. Software: ArcGIS (an electronic geographic information system).

4. Method: Interactive GIS mapping of catch locations by port, species, and season. Assess value using ex-vessel fish prices. Apply to different development scenarios.

\section{Cost and Level of Effort}

Total cost: $\$ 127,000$

Date Information Is Required: A summary report and interactive CD will be available by mid-2009. 


\section{Proposed Study Profile}

Region: $\quad$ Alaska

Planning Area: $\quad$ North Aleutian Basin

Title: $\quad$ Bering Sea Fish Catalog

MMS Need for Information: MMS needs organized fish ecology and behavior information for Arctic Alaska environmental impact assessments and informed decision-making pertaining to leasing activity in Arctic Alaska.

Period of Performance: FY 2007-2010

\section{Description}

\section{Background}

The most comprehensive source of data on the distribution and biology of Bering Sea fishes and benthic invertebrates are provided by the groundfish bottom trawl surveys conducted each summer by the Alaska Fisheries Science Center. The data series, which extends back to 1972, includes the catch in weight and numbers per unit of area trawled, size distribution by sex, and for select species, age, body weight, and maturity. Currently these data reside in the RACEBASE Oracle database, which is accessible only to Alaska Fisheries Science Center staff; however, a new database is under construction that will have a Web-based interface allowing extraction of data and GIS mapping. One way to increase the access of these data for MMS staff is to speed up the development of the Web-based access system by using contract html and Oracle programmers. Another contract person would be hired to construct a metadata section of the database that better defines its contents and allows the user to make more informative selections of data for further analysis and plotting.

\section{Objectives}

1. Build a Web-based access system to the RACEBASE survey database using contract $\mathrm{html}$ and Oracle programmers. The system will allow data selection, downloading, and plotting with a GIS system.

2. Build a Web-based metadata catalog for RACEBASE so that uninformed users can quickly understand the content of the database and formulate data selections more efficiently. The catalog will also document changes in survey methodology to allow more appropriate interpretation of survey results.

\section{Methods}

1. Contract html and Oracle programmers will be hired to build a Web-based access system to RACEBASE and create a metadata catalog to allow a better understanding of the content of the database. This will allow MMS staff and others to directly query the database and either have the resulting data downloaded or plotted with a GIS. 


\section{Cost and Level of Effort}

Total cost: $\$ 150,000$

Date Information Is Required: Contract programmers will be hired in early FY 2007. The metadata catalog will be completed during FY 2007 and the final Web-based access system will be completed by October 2009 . 


\section{Proposed Study Profile}

Region: $\quad$ Alaska

Planning Area: $\quad$ North Aleutian Basin

Title: $\quad$ Bering Sea Seasonal Fish Migration

MMS Need for Information: Marine fish species are important in the Bering Sea ecosystem and to the coastal communities. Distribution patterns of these fish are available only during the summer when they are surveyed by the Alaska Fisheries Science Center bottom trawl survey. The proposed study will discern the seasonal movements of individual fish and allow estimation of fish distribution during other seasons. Study information will be used in NEPA analyses and documentation for North Aleutian Basin lease sales and for development and production plans.

Period of Performance: FY 2007-2010

\section{Description}

\section{$\underline{\text { Background }}$}

Evaluation of the potential environmental impacts of oil and gas development in the Bering Sea requires knowledge of the spatial distributions of marine fishes throughout the year. Such distributions are determined each summer by the groundfish trawl surveys that have been conducted by the Alaska Fisheries Science Center since 1972. Since many fish species are known to make extensive seasonal migrations, summer distributions may not be indicative of distributions at other times of the year. Using bottom trawl surveys to determine distributions outside of the summer months is difficult and often ineffective because the short days and rough seas severely reduce the number of stations that can be completed per day. An alternative way of determining seasonal fish movement is to use fish tagging systems that allow repositioning individual fish continuously over time. One such system, known as FRAFOS, is now in operation in areas along the East Coast. The system consists a number of low-frequency sound transmitters attached to moorings spread out at distances of 50-100 km. Individual fish are fitted with small tags housing acoustic receivers that record the arrival time of the sound pulse from each mooring. These data are then used to triangulate fish position. Tags are later retrieved from fish captured by the commercial fishery. The tags have a battery life of over two years and allow daily position fixes. Pacific cod and halibut, because they are large, robust fish with long migration paths, would be the first species to be tagged with this system.

\section{Objectives}

1. Obtain daily position data for Pacific cod and halibut to plot the trajectory of individual fish over the course of a year or more at liberty.

2. Combine the trajectories with the summer distributions to estimate the seasonal shift in distribution of each species. 


\section{Methods}

1. Place low-frequency transmitters on each of the four oceanographic moorings maintained by the Pacific Environmental Lab, and place two additional transmitters on new deepwater moorings.

2. Place FRAFOS tags externally on 50 cod and 50 halibut using standard Alaska Fisheries Science Center tagging methodology. Previous NMFS research placing similar tags on cod obtained about $40 \%$ return rate.

3. Since NMFS has an ongoing tagging program for cod and the International Pacific Halibut Commission has a similar program for halibut, little additional advertising will be required to inform the fishing community about the tag return program.

\section{Cost and Level of Effort}

Total cost: $\$ 350,000$ including $\$ 100,000$ for a vessel

Date Information Is Required: Study information will be used in NEPA analyses and documentation for North Aleutian Basin lease sales and for development and production plans. The initial placement of transmitters and deployment of FRAFOS tags will begin in July 2007. Fish trajectories and movement patterns should be completed in December 2009. 


\section{C.4 BIRD STUDY PROFILES}




\section{Proposed Study Profile}

Region: $\quad$ Alaska

Planning Area: $\quad$ North Aleutian Basin

Title: $\quad$ Spatial and Temporal Distribution of Steller’s Eiders and Other Waterbirds in the North Aleutian Basin Project Area

MMS Need for Information: Present spatial and temporal information on Steller's eiders and several other bird species of management concern is inadequate to predict and assess potential impacts of oil and gas exploration and development in the North Aleutian Basin planning area. Study information will be used in NEPA analyses and documentation for North Aleutian Basin lease sales, for exploration plans, and for development and production plans. This study is considered the highest priority of the six bird studies proposed for the North Aleutian Basin.

Period of Performance: FY 2007-2011

\section{Description}

\section{Background}

The project area, especially the lower Alaska Peninsula lagoons, is widely known as critical habitat for the federally listed Steller's eider, and as a staging and molting area for many shorebirds and waterfowl of global and regional conservation concern. For instance, the entire listed population of Steller's eiders is present in the North Aleutian Basin during major portions of their annual cycle. In addition, the area hosts nearly the entire populations of species of management concern, including Pacific brant, Emperor geese, and cackling Canada geese, during portions of the year. The importance of the area to waterbirds is reflected in the designation of over 40 sites protected under various international, federal, state, and other programs. However, most distribution and abundance data are both out of date and seasonally biased, and thus inadequate for evaluation of waterbirds' vulnerability to both acute and chronic impacts of oil and gas activities.

\section{Timing Needs}

Because potential impacts would occur from all phases of leasing, the need for this information is immediate.

\section{$\underline{\text { Objectives }}$}

The study would document abundance and distribution of waterfowl and shorebirds throughout the annual cycle within bays, lagoons, and other nearshore habitats between Izembek Lagoon and Goodnews Bay.

\section{Methods}

1. Aerial surveys: Seasonal shoreline-based comprehensive aerial surveys would be conducted, using methods described in Larned (2005), and Mallek and Dau (2006). These 
methods consist of periodic censuses, augmented by replicated sampling schemes for certain habitats, e.g., Kvichak Shoals. Winter distribution will be emphasized because that is the season about which the least is known.

2. Ground-based shorebird surveys: Small camps will be distributed at four to six locations between Izembek Lagoon and Kvichak Bay. Personnel in camps will document species composition, estimate abundance, peak arrival and peak departure, and estimate turnover rates throughout the spring and fall migration periods. Several winter visits would be made to determine the presence of rock sandpipers and other shorebirds in post-migration periods.

3. Telemetry: Use conventional and satellite telemetry techniques to determine distribution, turnover rates, and habitat use. Investigate use of geolocator recording devices as a means to determine characteristics such as habitat use, migration timing, and turnover rates.

\section{Cost and Level of Effort}

Costs would include permits needed for Steller's eider implants; public relations efforts with subsistence hunters; and weather constraints for aerial surveys in all seasons, particularly winter; one full-time and three part-time principal investigators (PIs) and one technician; and operations costs. The estimated costs are as follows:

- 1 PI (full time, $\$ 100,000$ ) + 3 sub-PIs (1 for each major methodology, half year, $\$ 50,000$ each) +1 technician (full time, $\$ 50,000)=\$ 300,000 /$ year $\times 5$ years $=\$ 1.5$ million

- Aerial surveys $\$ 40,000 /$ survey $\times 5$ surveys/year $=\$ 200,000 /$ year $\times 5$ years $=\$ 1$ million

- Ground surveys logistics, materials, and analytical $\$ 60,000 /$ year $\times 5$ years $=\$ 300,000$

- 20 telemetry transmitters at $\$ 7,000$ each $=\$ 140,000$

- Total cost: \$2.94 million

Date Information Is Required: Prior to lease-sale EISs. 


\section{Proposed Study Profile}

Region: Alaska

Planning Area: $\quad$ North Aleutian Basin

Title: $\quad$ Spatial and Temporal Distributions of Birds at Sea

MMS Need for Information: The lack of seasonal at-sea distribution and abundance information on short-tailed albatross and other seabirds makes it impossible for MMS to adequately complete impact analyses as required by NEPA or to complete Section 7 consultations for the proposed lease sales in the North Aleutian Basin. A number of oil and gas exploration and development activities have the potential to directly and indirectly impact a number of bird species, but the estimated magnitude or significance of these effects would be inaccurate if based on existing datasets.

Information gained from this research would allow the MMS analysts and managers in cooperation with other interested parties to address major gaps in knowledge for over 60 species. In addition, this information would provide valuable documentation for analysts and managers for lease sales in the 2007-2012 program and development and production plans from existing leases. This study is considered the second highest priority of six bird studies proposed for the North Aleutian Basin.

Period of Performance: FY 2007-2011

\section{Description}

\section{Background}

Breeding seabirds are generally monitored at colonies, yet they spend most of the year dispersed offshore. Additionally, one half or more of all seabirds do not breed because they are too young or there is limited nesting habitat. Recently, U.S. Geological Survey and USFWS consolidated historic at-sea survey data into the North Pacific Pelagic Seabird Database (NPPSD), but most of these data were collected in the 1970s-1980s. MMS will require current data on seabird distribution and abundance in the North Aleutian Basin. Since the 1980s many seabird species have declined and changes have occurred in ocean ecosystems. These changes may have affected the foraging patterns of seabirds. To address this data gap, this project would update seabird distribution data for the southern North Aleutian Basin. It would also provide first-time coverage for the northern Basin, which has not been adequately surveyed previously, and would include the winter months, for which few at-sea data have been collected. This project will use standardized protocols for marine bird surveys. Data will be entered into the NPPSD, providing access to multiple users. The final goal will be to integrate the seabird data with the oceanographic and fisheries data, to determine what oceanographic properties and prey distribution define bird distribution in the Basin.

The study would be implemented in two phases, with the first efforts focused on seabird distribution in offshore waters covered by ongoing fisheries and marine mammal surveys. The 
second phase will require dedicated surveys using smaller vessels and support vessels to survey more nearshore waters, particularly in the northern Basin.

\section{Timing Needs}

Phase one would conduct surveys beginning in 2007, and would likely continue through summer 2009. The second phase would occur from 2008 through 2010.

\section{Objectives}

1. Describe spatial and seasonal distribution of birds at sea in the North Aleutian Basin.

2. Implement collaborative studies of prey availability by working with concurrent studies of invertebrate, zooplankton, and forage fish availability within foraging range of the selected colonies.

\section{Methods}

1. Coordinate with oceanographic, fisheries, and marine mammal research to conduct at-sea surveys for birds.

2. When coordination with other studies does not meet the requirements of this project, survey vessels will be contracted to provide survey platforms.

3. Adult diet will be determined by collection of adults at foraging sites, in cooperation with oceanographic and fisheries (invertebrate and forage fish) studies.

\section{Cost and Level of Effort}

Costs would include vessel charter time (assuming no coordination with other projects) for 6 months/year $(\$ 600,000)$. Beyond ship contracts, basic yearly operating costs include travel $(\$ 30,000)$, permanent and seasonal personnel $(\$ 150,000)$, equipment and diet analysis $(\$ 50,000)$. Total $=\$ 830,000 /$ year, 2007-2010 (without ship time, \$230,000). A final year of synthesis and completion of final report $=\$ 100,000$.

Total cost: $\$ 3.42$ million

Date Information Is Required: Data to be entered annually into the NPPSD. Annual reports on survey effort will be provided. Final report completed in 2011. 


\section{Proposed Study Profile}

Region: $\quad$ Alaska

Planning Area: $\quad$ North Aleutian Basin

Title: $\quad$ Seabird Colony Census and Diet Studies in the North Aleutian Basin and Southern Alaska Peninsula

MMS Need for Information: The data on seabird colonies in the North Aleutian Basin are not current, which makes it difficult to address potential impacts to seabird populations within the proposed lease-sale areas relative to potential offshore oil and gas exploration and development. Information gained from this research would allow MMS analysts and managers in cooperation with other interested parties to address major gaps in knowledge for use in NEPA evaluations for the oil and gas activities in the North Aleutian Basin. This study is considered the third highest priority of the six bird studies proposed for the North Aleutian Basin.

Period of Performance: FY 2007-2011

\section{Description}

\section{Background}

In the proposed lease-sale area and adjacent North Aleutian Basin there are approximately 44 seabird colonies and nearly a million nesting birds of 26 species. Most of the colony census data is $10-20$ years old, and current breeding population sizes are not known. Additionally, seabird diet during the breeding season has only been studied sporadically and opportunistically at a few colony sites. Since these colonies have been surveyed, there have been major changes in the marine ecosystem, which could have affected seabird population trends and foraging habits. Similar data gaps exist for seabird colonies on the south side of the Alaska Peninsula, where approximately 2 million birds were recorded nesting in past surveys. Cumulatively, the colonies in this region represent a substantial proportion of the breeding seabirds along the North American coasts. Seabirds are a protected resource under the Migratory Bird Treaty Act and international treaty obligations.

Seabird colonies on the north side of the Alaska Peninsula will be affected by early exploration and development activities. Seabird colonies on the south side will be affected during development of transportation infrastructure and vessel traffic during the production and oil delivery phase. Thus, this study would be implemented in two phases, with the first efforts focused on seabird colonies on the north side, and the second focused on the seabird colonies on the south side of the Alaska Peninsula.

\section{Timing Needs}

During Phase 1, censuses would be conducted of colonies in the North Aleutian Basin beginning in 2007, and would likely continue through summer 2009. Phase 2 studies would cover the south Alaska Peninsula in 2009 through 2011. 


\section{$\underline{\text { Objectives }}$}

1. Re-census colonies in the North Aleutian Basin area.

2. Re-census colonies on the southern Alaska Peninsula within $150 \mathrm{~km}$ of any proposed oil transport facility.

3. Conduct diet studies at selected colonies in the North Aleutian Basin and southern Alaska Peninsula.

4. Implement collaborative studies of prey availability by working with concurrent studies of invertebrate, zooplankton, and forage fish availability within foraging range of the selected colonies.

\section{Methods}

1. Colony census techniques will follow protocols outlined in Alaska Maritime National Wildlife Refuge (AMNWR) and USFWS manuals. Colony censuses will be prioritized following the USFWS report Colony Re-Census Plan, which provides dates of last census and reliability of census data for each site. The new colony census data will be integrated into the Seabird Colony Database housed with USFWS in Anchorage.

2. Chick diet will be monitored by collecting prey deliveries at the nest of species representative of all foraging guilds of locally nesting birds. Diet studies will be coordinated to complement the sampling conducted at colonies monitored by the AMNWR and associated Seabird, Marine Mammal, and Oceanographic Coordinated Investigations study locations.

3. Adult diet will be determined by collection of adults at foraging sites, or by nonlethal methods where possible. A second phase of the diet study would begin a reference study of fatty acid signatures for prey in the Basin to facilitate future diet studies that will not require collection of seabird stomachs.

4. Data on prey availability (from plankton and fish studies) will be integrated with the seabird diet information via a link with the seabird diet database being developed by USFWS and AMNWR.

\section{Cost and Level of Effort}

Yearly costs would include vessel charter time for 2 months/year $(\$ 150,000)$, permanent and seasonal personnel $(\$ 120,000)$, equipment and camp/collection operations and diet analysis $(\$ 80,000)$. Total $=\$ 350,000 /$ year from 2007 to 2010. A final year of synthesis and completion of final report $=\$ 120,000$.

Total cost: \$1.52 million

Date Information Is Required: Colony census data to be entered annually. Annual reports on colony and diet studies available January following field season. Final report completed in 2011. 


\section{Proposed Study Profile}

Region: Alaska

Planning Area: $\quad$ North Aleutian Basin

Title: $\quad$ Aerial Remote Sensing of Distribution and Abundance of Eelgrass in the North Aleutian Basin Planning Area

MMS Need for Information: Eelgrass resources are an important component of the estuarine and nearshore systems of the North Aleutian Basin. Eelgrass is important forage for eiders, brant, and nursery for juvenile marine and anadromous fish, and is vital to nutrient input and cycling of the North Aleutian Basin. Understanding the distribution and abundance of eelgrass is essential and will enable MMS to more thoroughly understand and predict the potential effects of oil and gas development in the North Aleutian Basin. This study is considered the fourth highest priority of the six bird studies proposed for the North Aleutian Basin.

Period of Performance: FY 2008-2010

\section{Description}

\section{Background}

Eelgrass studies are needed to obtain current distribution and abundance information. Data at the most basic level outside of Izembek Lagoon is needed. This study will begin to establish baseline knowledge of eelgrass distribution and status in the North Aleutian Basin planning area.

\section{$\underline{\text { Objectives }}$}

1. Map distribution and abundance of eelgrass within the North Aleutian Basin planning area.

2. Design a long-term eelgrass monitoring plan for the North Aleutian Basin planning area.

\section{Methods}

1. Review existing imagery.

2. Evaluate sources of imagery (i.e., satellite, low-level photography, ground survey) and expand as necessary.

3. Design survey methods for long-term comparability, cost-effectiveness, and incorporation of future technological and remote sensing advances.

4. Conduct the survey according to most the appropriate methodology for mapping distribution and abundance.

5. Digitize data.

6. Determine level of sampling necessary to monitor changes in distribution and abundance. 


\section{Cost and Level of Effort:}

Total cost: $\$ 400,000$

Date Information Is Required: Study products are presently needed to enhance assimilation into environmental assessment and NEPA process of the North Aleutian Basin. The survey design will be due July 2007. Initial surveys will be implemented in May through September 2008. Initial survey results will be due April 2009. Draft and final reports are due October and December 2009, respectively. 


\section{Proposed Study Profile}

Region: Alaska

Planning Area: $\quad$ North Aleutian Basin

Title: $\quad$ Estuarine System Studies - Izembek and Port Moller Lagoons

MMS Need for Information: Bird resources are an important component in the estuarine systems of the North Aleutian Basin. Understanding the structure and function of these systems, represented by Izembek and Port Moller Lagoons, will enable MMS to more thoroughly understand and predict the potential effects of oil and gas development in the North Aleutian Basin. This study is considered the fifth highest priority of the six bird studies proposed for the North Aleutian Basin.

Period of Performance: FY 2007-2010

\section{Description}

\section{Background}

Consistent estuarine systems studies are needed to obtain fundamental and current resource information. Data at the most basic level are needed. There has been no effort to date to use an interdisciplinary approach to understand these systems, of which birds are an integral element. Izembek and Nelson Lagoons and the Port Moller complex are among the most important estuarine systems in North America and are globally important (Ramsar convention designation). In addition to the need for basic distribution data, ecological information is necessary to assess the potential effects of offshore development. However, life history strategies, foraging, population dynamics, and other aspects of estuarine bird behavior and ecology are, for the most part, poorly understood.

This study will begin to establish baseline knowledge of bird ecology in the North Aleutian Basin planning area. Concurrent collection of interdisciplinary data will help complete our understanding of these systems.

\section{Objectives}

1. Design a long-term bird monitoring plan for Izembek and Nelson Lagoon/Port Moller complex, including:

- Distribution and habitat use (seasonal, spatial, temporal patterns of movement)

- Abundance (seasonal, spatial, temporal)

- Forage requirements

- Stressors

- Background contaminants levels

- Disturbance and consumption use

- Predation 
- Climate, including ice cover

- Forage quantity and quality

Focal species for these monitoring efforts are:

- Brant (Izembek Lagoon only)

- Emperor goose

- Steller's eider

- Dunlin

- Western sandpiper

2. Ensure that interdisciplinary evaluations of system components known to determine bird use of these areas, such as chemistry, climate, oceanography, benthic, vegetative (i.e., mapping of eelgrass distribution), fish, and marine mammals, are done concurrently and combined with the above bird information to form an understanding of the function of these systems.

\section{Methods}

1. Construct and evaluate conceptual model.

2. Review existing data sources.

3. Evaluate existing survey designs and expand as necessary.

4. Design survey methods for long-term comparability, cost-effectiveness, and incorporation of future technological and remote sensing advances.

5. Conduct survey to determine distribution, abundance, and patterns of movements.

6. Conduct survey to determine forage relationships.

7. Conduct study to determine physiological requirements of focal species, being certain to include background levels of contaminants and other stressors.

8. Combine focal species information with other interdisciplinary data.

\section{Cost and Level of Effort}

$\$ 250,000 /$ year for 3 years (not including cost-sharing with physical sciences)

Total cost: $\$ 750,000$

Date Information Is Required: Study products are presently needed to enhance assimilation into environmental assessment and NEPA process of the North Aleutian Basin. The study design will be due July 2007. Initial design will be implemented in October 2007. Initial model will be operating by October 2008. Operational model will be completed by October 2009. 


\section{Proposed Study Profile}

Region: Alaska

Planning Area: $\quad$ North Aleutian Basin

Title: $\quad$ Spatial and Temporal Patterns of Bird Movements

MMS Need for Information: Recent interest for oil development in the North Aleutian Basin requires some knowledge of marine bird distribution and timing of use. In particular, it is critical to identify high-use areas within the region for Steller's eiders, short-tailed albatross (listed as endangered), and other species of concern due to declining population trends, global importance, and the increased potential for collisions with oil and gas infrastructure. This area is of international importance to a wide variety of birds that use the area for important life history stages including migration stopovers, overwintering, and molting. The general lack of information on pre- and post-breeding movements and staging areas makes it difficult to address potential oil and gas-related effects on these species molting, wintering, and staging in this region. Information gained from this research would allow MMS analysts and managers, in cooperation with other interested parties, to address some major gaps in knowledge for these species required for NEPA evaluations of proposed oil and gas development activities in the North Aleutian Basin. This study is considered the lowest priority of six bird studies proposed for the North Aleutian Basin.

Period of Performance: FY 2007-2011

\section{Description}

\section{Background}

The North Aleutian Basin is of international significance because birds from throughout North and South America and Asia congregate there. Locally, it is well documented that birds in the pelagic environment are attracted to light sources. Thousands are killed annually in collisions with vessels. Millions of waterfowl, shorebirds, and seabirds migrate through, breed, overwinter, and stage in the lease area, including Steller's eiders and short-tailed albatrosses, both listed species. The planning area provides wintering habitat for approximately $70 \%$ of the Pacific population of Steller's eiders.

Millions of birds may move through and forage within the lease area. They may be attracted to manmade light sources and vulnerable to striking manmade objects. As exploration and operations activities proceed in the planning area there will be a significant increase in the amount of light and consequently the potential for increased bird strikes.

On a larger spatial scale, it is well known that large numbers of species that use the area for molting, staging, or overwintering migrate to distant locations to complete their annual life cycles. Thus, any effects from oil and gas leasing and exploration may have consequences at an international level. 


\section{Objectives}

1. Develop a model to be used by MMS to assess the potential for bird strikes in the North Aleutian Basin by identifying the timing, patterns of movement, species composition, and numbers of birds transiting the lease area and correlate these movements with weather and other environmental variables.

2. Identify the patterns of movements of birds on local and global spatial scales throughout annual cycles.

3. Facilitate analysis of survey data by identifying movements and turnover rates within the lease area.

4. Mark birds with a variety of life histories including common murres, black-legged kittiwakes, crested auklets, shearwaters, dunlins, Steller’s and king eiders, and black scoters.

\section{Methods}

1. Mark a sample of birds within the proposed lease-sale area (multi-species) using telemetry (in combination with other distribution studies).

2. Conduct onshore and offshore radar studies.

3. Record onshore and offshore visual observations (in combination with other distribution studies).

\section{Cost and Level of Effort}

$\$ 500,000 /$ year for 5 years

Total cost: $\$ 2.5$ million

Date Information Is Required: Prior to the completion of any development and production plan EIS. 


\section{C.5 MARINE MAMMAL STUDY PROFILES}




\section{Proposed Study Profile}

Region: Alaska

Planning Area: $\quad$ North Aleutian Basin

Title: $\quad$ Distribution, Abundance, and Habitat Use of North Pacific Right Whales

MMS Need for Information: The eastern population of the North Pacific right whale (Eubalaena japonica) is arguably the rarest stock of whales anywhere in the world. Right whales throughout the North Pacific were drastically reduced by commercial whaling beginning in 1835, and the remnant eastern population was almost wiped out by illegal Soviet catches in the 1960s. Today, the surviving population likely numbers fewer than 100 whales, although little is known of its abundance, movements and current habitat use. Because of its endangered status under the ESA (and designated as "critically endangered" by the International Union for the Conservation of Nature and Natural Resources), the eastern North Pacific right whale is among the highest priorities for recovery efforts by NMFS. Under NEPA, MMS will be required to evaluate how federal actions associated with oil and gas development may impact right whales, which are known to feed in the North Aleutian Basin lease-sale area. The occurrence, distribution, and habitat use of this species in the area may play an important role in determining where and when exploration or access to petroleum reserves may be conducted.

Period of Performance: FY 2007-2010

\section{Description}

\section{Background}

Historical data as well as recent observations confirm that the North Aleutian Basin lease-sale area is used by right whales for at least the period May through September; although it is generally assumed that the animals migrate out of the area during winter, this assumption is based on very little information and has never been confirmed. It is also assumed that right whales occupy the North Aleutian Basin area to feed on copepods, but oceanographic and foraging ecology studies of the region that would support this assumption are lacking. Multidisciplinary surveys of the lease-sale area and adjacent regions would provide crucial information on the occurrence and habitat use of right whales in this region. A parallel study would examine movements of individual whales using satellite-monitored radio tags, a technique that has proven very useful in this and other species of large whales because it allows more costeffective and practical collection of distributional information for longer periods than can be obtained by regular sighting surveys.

\section{$\underline{\text { Timing Needs }}$}

Because of the extremely vulnerable status of this population and the potential for industry activities (notably seismic surveys) to begin as early as 2007 or 2008, it is essential that at least the tagging work is begun in the summer of 2007. At least three seasons of study are required to capture interannual variation in animal movements and habitat characteristics and to increase the sample size of tagged whales. 


\section{$\underline{\text { Objectives }}$}

1. Conduct a multidisciplinary project involving aerial- and ship-based sighting surveys, and physical and biological sampling to characterize right whale habitat over spatial scales of tens of kilometers in and around the Basin.

2. Through animal-borne acoustic tagging and concurrent oceanographic observations, characterize right whale foraging behavior and prey distribution over spatial scales of hundreds of meters to kilometers.

3. Through animal-borne satellite tagging, determine the extent to which the Basin is used by right whales, and their movements throughout the Bering Sea and elsewhere.

4. Collect biopsy samples of right whales for genetic, pollutant, and dietary analysis, and samples of copepods to establish a prey pollutant baseline.

\section{Methods}

We will conduct several integrated research activities from the same platform in the same region that will provide information on right whale ecology and behavior at various spatial scales; these will include sightings surveys (quarterly aerial surveys, annual ship-based surveys), physical/biological sampling, and acoustic and satellite tagging of whales. Integration of these activities will ensure that observations at one spatial scale can be appropriately interpreted in the context of observations at larger spatial scales. We will coordinate our activities with other programs (e.g., Bering Ecosystem Study and North Pacific Research Board's Integrated Ecosystem Research Program) so that our relatively small-scale observations can be put into the context of conditions and processes occurring over the broader Bering Sea. The satellite tagging portion of the project will begin in the summer of 2007 and will involve attaching up to 15 tags to right whales in the southeastern Bering Sea over 3 years. Integrated ecosystem observations and sighting surveys will begin in 2008.

Distribution and movement data from this study will be combined with information from acoustic recording devices (see separate study plan) to assess the occurrence of right whales in the Basin year-round and, possibly, to study the response of tagged whales to seismic surveys.

Biopsy samples of right whales will be taken during tagging operations for analysis of genetics, pollutants, and diet. In addition, samples of copepods will be taken during oceanographic operations to establish a baseline for contaminants in right whale prey prior to oil and gas development activity.

\section{Cost and Level of Effort}

- $\quad$ FY 2007: \$615,000 (cruise, aerial surveys, and satellite tagging)

- FY 2008: \$1,050,000 (cruise, aerial surveys, satellite tagging, and oceanography)

- FY 2009: \$1,050,000 (cruise, aerial surveys, satellite tagging, and oceanography)

- $\quad$ FY 2010: \$475,000 (aerial surveys, analysis, and write-up)

- Total Cost: \$3.19 million 
Date Information Is Required: A final report is needed by the end of the funding period, September 2010. Information derived from the earlier phases of the tagging study should be made available as soon as possible to assess potential impacts of industrial activity on movements and habitat use. 


\section{Proposed Study Profile}

Region: Alaska

Planning Area: $\quad$ North Aleutian Basin

Title: $\quad$ Seasonal Acoustic Monitoring of Right Whales and Other Endangered Cetaceans in the North Aleutian Basin

MMS Need for Information: At least nine species of cetaceans are known to occur in the North Aleutian Basin lease-sale area. These include the North Pacific right whale (Eubalaena japonica), humpback whale (Megaptera novaeangliae), fin whale (Balaenoptera physalus), gray whale (Eschrichtius robustus), minke whale (Balaenoptera acutorostrata), harbor porpoise (Phocoena phocoena), Dall's porpoise (Phocoena dallii), Pacific white-sided dolphin (Lagenorhynchus obliquidens), and the killer whale (Orcinus orca). It is likely that, to one extent or another, the area represents a feeding ground for all of these species during at least spring, summer, and fall; however, there has been relatively little survey effort in the region, and none during winter. Recent data from autonomous recording devices in the Gulf of Alaska and southeast Bering Sea (i.e., the North Aleutian Basin lease-sale area) have indicated that some species (including fin whales) are present year-round, a finding that contradicts conventional wisdom about migratory behavior. Such devices offer great potential to continuously monitor the occurrence of cetaceans, as well as to obtain baseline ambient noise data and information on calling rates during exploratory activities.

Overall, the pattern of occurrence of cetaceans in the Basin is unclear, and needs to be clarified in light of the likely oil and gas development and associated activities. Under the NEPA, MMS will be required to evaluate how federal actions associated with oil and gas development may impact right whales and other cetaceans, which are known to feed in the Basin. The occurrence, distribution, and habitat use of all of these species in the area may play an important role in determining where and when exploration or access to petroleum reserves may be conducted. Right whales are of particular concern given their critically endangered status and the paucity of knowledge regarding the extent to which they use the Basin.

Period of Performance: FY 2007-2010

\section{Description}

\section{Background}

North Pacific right whales are critically endangered as a result of commercial whaling beginning in 1835 and devastating illegal catches by the USSR in the 1960s. They are known to use the Basin as a feeding ground, but the nature and extent of their occurrence remains unclear, and acquisition of this knowledge is urgently required for recovery efforts and petroleum resource development activities. Surveys conducted periodically by NMFS since 1999 have recorded other cetaceans in the region in summer, but the expense of conducting season-long or year-round visual surveys in the Bering Sea has precluded development of a clear picture of cetacean habitat use in this region. In contrast, acoustic monitoring is a proven means of 
detecting cetacean vocalizations over months or years, with the added advantage that detections are 24 hours a day, as well as during the darkness and bad weather that hinder visual observation.

\section{Timing Needs}

Because of the potential for seismic surveys as early as 2007 or 2008, it is essential that recorders be deployed in the summer of 2007. This will allow gathering of baseline acoustic data - or, in the event that seismic work is occurring in the summer of 2007, would ensure that recorders were in place to assess the potential impact of these surveys.

\section{Objectives}

1. Deploy passive acoustic recorders in the Basin to monitor occurrence of right whales and other cetaceans year-round.

2. Compare acoustic results with data from visual surveys conducted in the region to assess the vocalization rate relative to the number of whales observed.

3. Collect baseline ambient noise data, and assess changes in calling rates during and following seismic surveys.

\section{Methods}

Acoustic monitoring will be conducted using passive acoustic recorders (i.e., PMEL recorders, DASARS, HARPS, PALS, and/or Cornell Pop-ups) deployed in the Basin, and subsequently retrieved for analysis after variable periods of from several months to more than a year. The devices will be deployed beginning in the summer of 2007, and will be rotated in and out on a regular schedule coincident with the availability of vessel support.

Stored acoustic data will be analyzed subsequent to retrieval beginning in 2008, and results will be used to modify the design of visual and oceanographic surveys for right whales as appropriate. Comparison of the acoustic data with sightings of right whales from planned visual surveys and satellite tagging studies will permit an assessment of the proportion of the local population that is vocalizing (and thus acoustically detectable). Detection of seismic survey noise will also permit a comparison of cetacean calling rates during and after such activities.

\section{Cost and Level of Effort}

- $\quad$ FY 2007: \$350,000 (recorder construction and salary)

- FY 2008: \$150,000 (recorder turnaround and salary)

- FY 2009: \$150,000 (recorder turnaround and salary)

- $\quad$ FY 2010: \$70,000 (analysis and salary)

- Total Cost: $\$ 720,000$

Date Information Is Required: A final report is needed by the end of the funding period, September 2010. Analysis of acoustic data from earlier phases of the project should be provided as soon as practicable in order to enable preliminary assessments of species occurrence and impacts of seismic activity. 


\section{Proposed Study Profile}

Region: $\quad$ Alaska

Planning Area: $\quad$ North Aleutian Basin

Title: $\quad$ Abundance, Distribution, and Seasonal Movements of Humpback Whales, Fin Whales, and Other Cetaceans in the North Aleutian Basin.

MMS Need for Information: Humpback whales (Megaptera novaeangliae) and fin whales (Balaenoptera physalus) are both listed as endangered under the ESA. Both species, as well as other cetaceans, regularly use the Bering Sea and adjacent waters as a feeding ground in spring, summer, and fall. Under NEPA, MMS will be required to evaluate how federal actions associated with oil and gas development may impact these species, whose range is known from NMFS surveys to include the North Aleutian Basin lease-sale area. The occurrence, distribution, and habitat use of humpback and fin whales, and other cetacean species, may play an important role in determining where and when exploration or access to petroleum reserves may occur.

Period of Performance: FY 2007-2010

\section{Description}

\section{Background}

Humpback whales and fin whales both inhabit the Bering Sea during spring, summer, and fall, and feed there on euphausiids and small schooling fish. The humpback whales in this area are probably primarily part of the Central North Pacific stock, although it is known that some individuals in this region migrate to the western North Pacific to breed and calve. The population identity of fin whales in the region is less clear, but evidence from mark recoveries suggest that at least two breeding populations of this species (and eastern and western stock) mix on a common Bering Sea feeding ground. Both species were heavily exploited by commercial whaling in the North Pacific in the 20th century, with humpback whale populations suffering additional damage from illegal Soviet catches in the 1960s.

Although some distributional data exist regarding humpback whales, fin whales, and other cetaceans in the Basin, there are few data on their occurrence outside summer, and sighting surveys to fill these gaps year-round would be impractical and prohibitively expensive. A directed satellite-tagging study of both these large-whale species would provide essential information on the movements of individuals, the extent to which the Basin is used, and the population identity of these animals. Surveys for other cetaceans conducted concurrent to satellite tagging would provide valuable information about the distribution and occurrence of other species.

\section{Timing Needs}

Given funding and logistical constraints, the full program of work would likely not be practicable in the summer of 2007, although opportunistic tagging could be conducted at this time concurrent with a separate survey for right whales. The full project would begin in the 
summer of 2008, likely in July or August when weather conditions are optimal for field operations.

\section{Objectives}

1. Conduct ship-based sightings surveys of cetaceans in the Basin and adjacent regions to assess the distribution and local abundance of humpback whales, fin whales, and other cetaceans.

2. Through satellite tagging of individual fin and humpback whales, monitor their movements and use of the Basin and adjacent waters.

3. Through long-term tag attachments, assess the migratory destinations of individual whales and, thus, their population identity.

4. As possible, assess whether distribution and habitat use change in response to seismic survey activities.

\section{Methods}

Line-transect sighting survey protocols will be followed to obtain data on the local abundance and distribution of cetaceans in the lease-sale area and surroundings. During these surveys, searches will be made for humpback and fin whales that may be suitable for satellite tagging in the Basin and adjacent regions. Satellite tags will be attached to humpback and fin whales in the Bering Sea beginning in the summer of 2008, with preparatory work (and possibly a few tags put out) in 2007. Tags will be similar in design to those successfully deployed on humpback whales by the same researchers elsewhere; the transmitters are monitored by the ARGOS system. An appropriate research vessel will be chartered for approximately 3 weeks for the 2008-2009 tagging; any tags deployed in the summer of 2007 will be deployed on an opportunistic basis from a separate cruise whose principal objective will be the tagging of North Pacific right whales.

\section{Cost and Level of Effort}

- FY 2007: \$60,000 (preparation and opportunistic tagging)

- FY 2008: \$350,000 (cruise and satellite tagging)

- FY 2009: \$350,000 (cruise and satellite tagging)

- FY 2010: \$85,000 (salary and analysis)

- Total Cost: $\$ 845,000$

Date Information Is Required: A final report is needed by the end of the study, June 2010. 


\section{Proposed Study Profile}

Region: Alaska

Planning Area: $\quad$ North Aleutian Basin

Title: $\quad$ Health Assessment of Stranding Marine Mammals in the North Aleutian Basin

MMS Need for Information: There are many species of cetaceans and pinnipeds whose range includes the North Aleutian Basin and adjacent waters. Several of these species are critical components of the Alaska Native subsistence harvest, and have the potential to be negatively affected by oil and gas exploration and production that may soon occur in the Basin. Under NEPA, MMS will be required to evaluate how federal actions associated with oil and gas development may affect these species. The MMS will need current baseline information on causes of mortality for comparison with future years when the oil and gas industry initiates major operations in this area.

Period of Performance: FY 2008-2011

\section{Description}

\section{Background}

The North Aleutian Basin is a key part of the range of several species of marine mammals, including North Pacific right whales, humpback whales, fin whales, killer whales, harbor porpoise, Dall's porpoise, gray whales, Steller sea lions, harbor seals, spotted seals, sea otters, and walrus. These mammals are top-level consumers and as such, their health is a visible indicator of the "health" of the local ecosystem. Previous studies supported by the MMS (e.g., Fay et al. 1979) documented stranding levels and causes of mortality in the late 1970s, but no directed studies in this area have occurred recently.

\section{$\underline{\text { Timing needs }}$}

Given funding and logistical constraints, this study could likely not begin until 2008. In early FY 2008, existing survey data would be compiled and examined to identify areas where carcasses typically come ashore so aerial survey effort can be better focused. A full suite of seasonal surveys and necropsies should be conducted for 3 years, beginning in spring of 2008 . This study should be repeated periodically after this date if development and production become a reality.

\section{Objectives}

1. To identify and determine the normal spatial distribution and numbers of dead and moribund marine mammals by species, sex, and age along the coast of Bristol Bay and to determine the cause of mortality.

2. To collect blood and tissue samples and conduct analyses for contaminants and pathological conditions. 
3. To compare results collected from stranded animals to information from specimens collected from living populations.

\section{Methods}

Existing survey data will be compiled and examined to identify what new information exists on stranding rates in the Basin and to identify any "hot spots" where animals often come ashore. Aerial surveys of the Bristol Bay shoreline will be conducted once per month during the spring and summer to search for stranded marine mammals. Survey teams will include staff qualified to conduct necropsies of marine mammals. If feasible, once a marine mammal is found, the aircraft will land and staff will conduct a necropsy and collect tissue samples. If not feasible, staff will later attempt to access the area by boat. Tissue samples will be collected and analyzed for contaminants and pathogens. The final report will compare these data with information on marine mammal health collected via other studies.

\section{Cost and Level of Effort}

- $\quad$ FY 2008: \$200,000 (1/2 salary for one full-time staff, aircraft, contracts, travel)

- FY 2009: \$300,000 (full salary for one full-time staff, aircraft, contracts, travel, sample analysis)

- FY 2010: \$300,000 (full salary for one full-time staff, aircraft, contracts, travel, sample analysis)

- $\quad$ FY 2011: \$75,000 (salary, analysis, and preparation of final report and publication)

- Total Cost: $\$ 875,000$

Date Information Is Required: Final report is needed by the end of the study, September 2011. 


\section{Proposed Study Profile}

Region: $\quad$ Alaska

Planning Area: $\quad$ North Aleutian Basin

Title: $\quad$ Monitoring Seasonal Distribution and Diet of Endangered Steller Sea Lions in the Southeastern Bering Sea and Eastern Aleutian Islands

MMS Need for Information: The Steller sea lion is listed as endangered under the ESA and as a species of concern in the North Aleutian Basin proposed lease-sale area. Information on use of terrestrial and marine habitats by Steller sea lions in the southeastern Bering Sea, including the Basin, is necessary to ensure that oil and gas lease and development activities do not delay the species' recovery. Study findings will be required in NEPA analyses, ongoing ESA Section 7 consultations, and other reviews of post-sale and post-exploration decision making and mitigation.

Period of Performance: FY 2008-2010

\section{Description}

\section{Background}

Much of the Basin overlaps with designated critical habitat for the endangered western Steller sea lion. As recently as 50 years ago, there were approximately 50,000 sea lions inhabiting the eastern Aleutian Islands west of the Basin, and the total western Steller sea lion population in Alaska (west of $144^{\circ} \mathrm{W}$ through the Aleutian Islands and Bering Sea) likely numbered over 225,000. Currently, the eastern Aleutian Islands sea lion population numbers less than 10,000, but has been stable since 1990. Criteria in the draft Steller Sea Lion Recovery Plan indicate that the species must increase at 3\% per year for 30 years in order to be delisted.

The Basin area contains important foraging habitat for sea lions breeding on nearby rookeries on Sea Lion Rock (near Amak Island) and in the Krenitzen Islands west of Unimak Pass. To determine vital rates (survival and reproduction) and follow movements of sea lions, the National Marine Mammal Laboratory (NMML) individually marked (hot-branded) pups born on Ugamak Island in the eastern Aleutian Islands beginning in 2001. Marked sea lions from Ugamak have been sighted most often on haulouts or rookeries bordering the southeastern Bering Sea, indicating that the prey resources (e.g., salmon, pollock, Pacific cod, and Pacific herring) located there are crucial to their survival and reproduction. To date, 525 sea lions have been marked, and have been sighted on 29 different terrestrial haulouts or rookeries in the eastern Aleutian Islands, adjacent North Pacific Ocean, and southeastern Bering Sea, including the Pribilof Islands, Sea Lion Rock/Amak Island, and Round Island in Bristol Bay. Recent population modeling studies suggest that declines in reproductive rates since the late 1970s may be impeding recovery of the western Steller sea lion. Any additional proposed changes within the marine or terrestrial habitats of Steller sea lions that could adversely affect their reproduction or delay their recovery would require close study. 


\section{Timing Needs}

For information to be available in time to support EIS-related analyses and lease-salerelated ESA Section 7 consultations, surveys would need to be initiated in spring (March) 2008.

\section{Objectives}

1. Monitor abundance and pup production of sea lions in summer (June through July) and winter (March) on terrestrial haulout and rookery sites in the eastern Aleutian Islands, western Gulf of Alaska (North Pacific Ocean), Sea Lion Rock/Amak, and in Bristol Bay, 2008-2009.

2. Photograph and record sightings of marked sea lions on terrestrial haulout and rookery sites in the eastern Aleutian Islands, western Gulf of Alaska (North Pacific Ocean), Sea Lion Rock/Amak, and in Bristol Bay.

3. Collect food habits information (scat) to determine sea lion prey species in the eastern Aleutian Islands and southeastern Bering Sea.

\section{Methods}

Abundance on terrestrial sites will be monitored by aerial survey photogrammetry. Highresolution photographs of sea lions will be taken vertically over terrestrial sites by using a medium-format camera flying at 700-1,000 feet. Sea lions are counted by age and sex (pups, juveniles, subadult males, adult females, and adult males) from photographs back in the lab. Sea lion population structure (e.g., by age and sex) will be used in population models. Currently, the NMML conducts an aerial survey each summer to count adults and juveniles one year (nonpups in early to mid-June), and pups the next (late June to early July). Funds from this project will be used to extend the summer survey to Bristol Bay and the Pribilof Islands each year (5 days of flight time). In addition, an aerial survey would be conducted of the eastern Aleutian Islands, western Gulf of Alaska, and the ice edge in the southeast Bering Sea in March (10 days of flight time).

NMML conducts a vessel survey in the eastern Aleutian Islands and southeastern Bering Sea in summer (2 weeks during July and August) to record sightings of marked animals and to collect food habits information. For this study profile, a vessel would be chartered in May (1 week) to conduct the same research around haulouts in Bristol Bay during herring spawning time. Marked animals are recorded and photographed from small skiffs launched from a larger vessel; food habits information is collected by going ashore, flushing all animals into the water, and collecting scat. Funds requested would be used to pay for vessel charter and prey species identification.

\section{Cost and Level of Effort}

- FY 2007: \$225,000 (aerial survey and population modeling)

- FY 2008: \$225,000 (aerial survey and population modeling)

- Total Cost: $\$ 450,000$ 
Date Information Is Required: An annual interim report will be produced in late 2008 and a final report will be produced in early 2010. 


\section{Proposed Study Profile}

Region: Alaska

Planning Area: $\quad$ North Aleutian Basin

Title: $\quad$ Seasonal Habitat Use by Endangered Steller Sea Lions of the North Aleutian Basin

MMS Need for Information: The Steller sea lion is listed as endangered under the ESA and as a species of concern in the North Aleutian Basin. Information on use of terrestrial and marine habitats by Steller sea lions in the southeastern Bering Sea, including the Basin, is necessary to ensure that oil and gas lease and development activities do not delay the species' recovery. Study findings will be required in NEPA analyses, ongoing ESA Section 7 consultations, and other reviews of pre- and post-sale and pre- and post-exploration decision making and mitigation.

Period of Performance: FY 2008-2010

\section{Description}

\section{Background}

The North Aleutian Basin includes habitat used by the endangered western stock of Steller sea lions. However, nothing is currently known regarding how this area is used by this species on a seasonal basis and which portions of the Basin are of critical importance to this species for foraging. Information on use of terrestrial and marine habitats by Steller sea lions in the southeastern Bering Sea, including the Basin, is necessary to ensure that oil and gas lease and development activities do not delay the species' recovery. Telemetry studies in the eastern Steller sea lion stock have shown that animals use haulouts as a central place from which foraging trips are made (Raum-Suryan et al. 2002, 2004). The close proximity of the Steller sea lion haulouts and rookery sites at Amak Island, Cape Newenham, Round Island, Akun, Akutan, and Ugamak to the Sale 92 Area suggests that this area may be used as a foraging location.

This study would focus on deploying telemetry instruments (SMRU tags) to monitor location and diving behavior of individual animals beginning in October 2008. A total of 15 instruments would be deployed on young of the year, juvenile, and, possibly, adult females. October 2008 is the earliest possible start date for this project given the current limitation on sea lion permits. Our experience with satellite tag longevity indicates that these deployments would return useful information through the winter and into the early spring of the following year. We propose a second deployment of instruments in May 2009 to gain information on how animals use the area through the summer months and into early fall. Given the molting process of this species, tags would likely fall off the animals in August or September. This deployment schedule would be repeated in the following year. By deploying instruments at two different times throughout the year, information on the habitat use of Steller sea lions throughout the annual cycle will be gained. 


\section{Timing Needs}

To have information available in time to support EIS-related analyses and lease-salerelated ESA Section 7 consultations, tagging activities would need to be initiated in October 2008.

\section{Objectives}

1. Determine seasonal distribution of Steller sea lion in the Basin. Determine the extent to which regions within the Basin are utilized by Steller sea lions for foraging, and the extent to which activities in the area could affect foraging efficiency.

2. Capture Steller sea lions using a variety of on-land or at-sea techniques and attach satellite-linked telemetry devices that record and transmit foraging depths and location. Highlight areas of critical importance through kernel home range analysis.

3. Identify dispersal (migration) through the area to other haulouts surrounding the Basin.

4. Monitor the health and condition of each captured animal.

5. Permanently mark individual animals captured so they may be included in population dynamic research in the area in the future.

\section{Methods}

During a 2-year period, two trips will be conducted during spring (April or May) and two during autumn (October or November) to capture and telemeter Steller sea lions among Unimak Pass and Amak Island/Sea Lion Rock areas, or other haulout locations within the Basin. Steller sea lions will be captured using a variety of on-land and at-sea techniques and immobilized with isoflurane gas anesthesia. Satellite telemetry transmitters will be attached and measurements of health and condition collected according to standard procedures developed at NMML, ADFG, and Alaska SeaLife Center. A licensed veterinarian will be present at all times when isoflurane is being administered. Dive depth data are stored by the telemetry device and transmitted when dry (e.g., when the sea lion is at the surface or hauled out on land) to Argos satellites. Locations are determined by triangulation by Argos and variance in location estimate is based on quality of received signals. At-sea distribution and habitat use will be determined through analysis of location and dive data by sea lion age and sex through the use of GIS, animal movement software, and new habitat use models being developed at NMML. All physiological tissues collected will be archived for future contaminants, disease, and diet assessments to provide baseline data in the event of catastrophic events (e.g., oil spill).

\section{Cost and Level of Effort}

- FY 2008: \$425,000 (animal capture and tagging)

- FY 2009: \$425,000 (animal capture and tagging)

- FY 2010: \$90,000 (data analyses and report preparation)

- Total Cost: $\$ 940,000$

Date Information Is Required: Prior to any ESA consultations for the Sale 92 Area. 


\section{Proposed Study Profile}

Region: Alaska

Planning Areas: $\quad$ North Aleutian Basin

Title: $\quad$ Seasonal Abundance, Movements and Marine Habitat Use of Harbor Seals and Spotted Seals in the North Aleutian Basin

MMS Need for Information: This study will provide valuable information about the abundance and marine habitat use of harbor and spotted seals within the North Aleutian Basin. The Basin harbor seal population experienced a serious decline in abundance prior to 1995, and very little information is known about spotted seals in the eastern Bering Sea. Both species are protected under the MMPA and are subsistence resources for Alaska Native communities. Information on the distribution, abundance and behavior will be useful for pre-lease activity permitting, lease sale and development, and production plan EISs, as well for baselines against which to monitor impacts of exploration, development, and production if oil- or gas-related development is undertaken in the North Aleutian Basin.

Period of Performance: FY 2008-2011

\section{Description}

\section{Background}

In recent decades, the abundance of harbor seals has declined across several regions in Alaska. Counts of harbor seals from aerial surveys in the Basin declined about $42 \%$ from the mid-1970s to the mid-1990s, though they have increased recently in part of the area. The significance and causes of the decline are unknown, but there is increasing concern about the present and future status of Alaska harbor seal populations. Because of the inherent vulnerability of harbor seals to spilled oil, and their use of on-shore and off-shore habitats, it is particularly important to assess the potential impacts of oil and gas activities on the harbor seal population within the Basin.

Little is known about the population status and trends of spotted seals in Alaska. Spotted seals are closely related to harbor seals, yet, unlike harbor seals, spotted seals have a close association with pack ice and tend to be wider ranging than harbor seals. The two species do, however, have overlapping distributions within the Basin, and like harbor seals, spotted seals use on-shore and off-shore habitats and are inherently vulnerable to the effects of spilled oil.

The Basin is one of only three areas where harbor seals and spotted seals are sympatric. Previous studies of harbor seals and spotted seals in the Basin have been conducted by the ADFG and the NMML. These studies have provided initial information about the movements and population trends of harbor and spotted seals, but have been of insufficient scope to satisfy the information needs associated with oil and gas activities. Aerial survey counts conducted during the molt period (August) by both organizations have provided information on harbor seal abundance and trends, but limited knowledge of seasonal changes in haulout behaviors and 
distribution would prevent reliable assessments of potential impacts during other times of the year. This study would provide a comprehensive investigation of seal movement and abundance across multiple seasons and years through coordinated aerial surveys and telemetry studies.

The overlapping distribution of harbor seals and spotted seals provides the opportunity to study two different species without significant additional logistical costs and constraints. Since each species is expected to use the marine habitat in a different manner, this study can provide a broader assessment of the impact of oil or gas exploration activities on marine predators throughout the North Aleutian Basin.

\section{Timing Needs}

To provide information in time to support EIS-related analyses and lease-sale-related ESA Section 7 consultations, animal instrumentation and aerial survey activities should begin in 2008.

\section{Objective}

The general goal of this study is to employ aerial surveys in conjunction with satellite telemetry to document the abundance, movements, foraging behavior, and marine habitat use of harbor seals and spotted seals in the Basin.

\section{Methods}

1. Capture and instrument 20 harbor seals and 10 spotted seals in two successive years $(\mathrm{N}=60)$ with satellite-linked data recorders. Seals to be instrumented will be captured from locations throughout the Basin, in relative numbers approximately proportional to the age and sex structure of the population and local abundance. The telemetry devices will provide GPS-quality locations, haul-out timelines, and data on dive behavior.

2. Conduct 1 year of seasonal aerial surveys for seals throughout the Basin to improve estimates of harbor seal and spotted seal seasonal abundance. Seasonal surveys would be scheduled for the second year of work and based on information learned from the telemetry deployments.

3. Develop necessary statistical analyses or statistical models to produce a correction factor for seal abundance derived from aerial surveys at haulout sites.

4. Use movement and behavioral data from this study with any existing published results or other data in a comprehensive analysis of harbor seal and spotted seal distribution and habitat use in or adjacent to the Basin.

5. Use text, maps, photographs, or other data summaries to portray harbor seal and spotted seal distribution and habitat use in the Basin in assessments of impacts of activities or oil spill risk analysis.

6. Coordinate with researchers from ADFG to build on the experiences and results of previous studies conducted at sites within the Basin.

7. Collaborate with other researchers and organizations to obtain outside support for the analysis of tissue samples collected during capture activities to assess population genetic structure, nutritional status, and health (e.g., baseline disease and contaminant loads). 


\section{Cost and Level of Effort:}

- FY 2008: \$495,000 (capture and instrumentation of 30 animals)

- FY 2009: \$550,000 (capture and instrumentation of 30 animals; seasonal aerial surveys)

- FY 2010: \$155,000 (data collection and analysis)

- FY 2011: \$155,000 (data collection and analysis)

- Total Cost: $\$ 1,355,000$

Date Information Is Required: Quarterly and annual reports are due in 2008-2010. A final report will be produced by July 2011. 


\section{Proposed Study Profile}

Region: $\quad$ Alaska

Planning Area: $\quad$ North Aleutian Basin

Title: $\quad$ Seasonal Distributions, Abundance and Habitat Use Patterns of Pacific Walruses in the North Aleutian Basin Planning Area

MMS Need for Information: Data on seasonal distributions, abundance, and habitat use patterns of Pacific walruses in the North Aleutian Basin are needed to assess and manage potential impacts of planned oil and gas exploration and development activities on the Pacific walrus population. Information on these ecological parameters is lacking or out of date, especially in light of environmental changes that have occurred in the Bering Sea in recent decades. Results from this study will provide information for lease sales, MMPA incidental take authorizations, NEPA analyses, and analysis and development of exploration and development plans. The results will also contribute information useful for developing mitigation measures to reduce potential impacts to walruses from proposed oil and gas exploration and development activities.

Period of Performance: FY 2008-FY 2010

\section{Description}

\section{Background}

The shallow productive waters of the Basin support some of the largest concentrations of Pacific walruses in the world. Large breeding aggregations form in late winter in the broken pack ice of northern Bristol Bay. Females and dependent young migrate out of the region in spring, following the retreating pack-ice to summer feeding areas in the Chukchi Sea. Adult male walruses remain in the Bristol Bay region through the ice-free season, foraging on rich beds of benthic invertebrates and resting at isolated coastal haulout sites. The number of walruses attending coastal haulout sites in northern Bristol Bay (Round Island, Cape Peirce, and Cape Newenham) has declined in recent years, while the number of animals using haulouts along the Alaska Peninsula (principally at Cape Seniavin) has increased.

Walruses are highly sensitive to anthropogenic disturbances. Noise associated with exploration activities such as seismic surveys, exploratory drilling, marine vessels, and helicopter and aircraft traffic has the potential to disrupt normal resting and feeding behaviors and displace animals from preferred habitats. The number of walruses occupying coastal haulouts in the vicinity of the Sale 92 Area (southwest Bristol Bay) appears to have increased in recent years; however, seasonal distributions, abundance, and habitat use patterns in the region are poorly understood. Information on these parameters is needed to assess potential impacts of proposed activities and to formulate effective mitigation strategies. 


\section{Timing Needs}

Pre-lease-sale seismic exploration activities in the Basin are anticipated in 2008. Lease sales are projected in 2010 and 2012. Baseline information regarding the seasonal distribution, abundance, and habitat use of walruses in the vicinity of lease-sale areas is required for assessing potential impacts and mitigating disturbances associated with proposed exploration and development scenarios. We propose that the monitoring activities described in this study profile be undertaken in 2008-2010 so that the results may be considered in environmental analyses of proposed lease sales.

\section{Objectives}

1. Document seasonal use patterns of walrus haulouts in the vicinity of the Sale 92 Area with aerial photography.

2. Investigate haulout attendance and foraging patterns and locations with satellite telemetry.

3. Use haulout attendance data to improve aerial survey design and provide sightability corrections for abundance estimates.

\section{Methods}

1. Conduct biweekly aerial surveys of coastal walrus haulouts along the Alaska Peninsula (April through September).

2. Deploy 30 satellite telemetry tags on walruses at coastal haulouts.

3. Use GIS and probability-based models to define important foraging habitats.

4. Use generalized linear models to estimate sightability correction factors for aerial surveys.

\section{Cost and Level of Effort}

- FY 2008: $\$ 220,000$

- $\quad$ FY 2009: $\$ 220,000$

- FY 2010: $\$ 220,000$

- Total Cost: $\$ 660,000$

Included costs:

- Satellite tags and data processing fees: $\$ 120,000 /$ year

- Fixed-winged aerial surveys: \$60,000/year

- Field operations and logistics: \$40,000/year

Date Information Is Required: Annual summary reports in December 2008, 2009, and 2010. Final summary report in spring 2011. 


\section{Proposed Study Profile}

Region: $\quad$ Alaska

Planning Area: $\quad$ North Aleutian Basin

Title: $\quad$ Seasonal Distributions, Abundance and Habitat Use Patterns of Northern Sea Otters in the North Aleutian Basin Planning Area

MMS Need for Information: Data on seasonal distributions, abundance, and habitat use patterns of northern sea otters in the North Aleutian Basin are needed to assess and manage potential impacts of planned oil and gas exploration and development activities on northern sea otters. Information on these ecological parameters is lacking or out of date. Results from this study will provide information for lease sales, ESA Section 7 consultations, MMPA incidental take authorizations, and NEPA analyses, and will provide information for the analysis and development of exploration and/or development plans. The results will also contribute information useful for developing mitigation measures (such as spatial or temporal operating restrictions) to reduce potential impacts to sea otters from proposed oil and gas exploration and development activities.

Period of Performance: FY 2009-FY2011

\section{Description:}

\section{Background}

Sea otters within the North Aleutian Basin are part of the southwest Alaska population stock, which was listed as a threatened distinct population segment under the ESA in August 2005. This distinct population segment declined in abundance by more than $50 \%$ in the past 20 years. In addition to a decline in abundance within the Basin, the population has also undergone a dramatic change in distribution over this time period. Up until the mid-1980s, the population was largely pelagic, with large aggregations of sea otters regularly observed $25 \mathrm{~km}$ or more from shore. Aerial surveys conducted in 2000 and 2004 revealed that the current population occurs closer to shore, with extremely high concentrations in the Port Moller and Herendeen Bay areas. In addition, this area is subject to the seasonal advance of sea ice, which can prevent access to feeding areas, thereby impacting sea otter distribution and survival. Recent survey information has been collected during relatively short time periods during summer months (May and July); therefore, seasonal patterns of habitat use are unknown.

\section{Timing Needs}

Pre-lease-sale seismic exploration activities in the Basin are anticipated as early as 2007. Lease sales are projected to occur no sooner than 2010. Baseline information regarding the seasonal distribution, abundance, and habitat use of sea otters in and adjacent to the Sale 92 Area is required for assessing potential impacts and mitigating disturbances associated with proposed exploration and development scenarios. The monitoring activities described in this study profile should be undertaken from 2009 through 2011. 


\section{Objectives}

Sea otters are currently distributed differently than they were prior to the decline in their population that resulted in their being listing as threatened. While current information suggests that the Port Moller and Herendeen Bay areas provide important habitat, the degree to which sea otters use other areas at different times of the year is unknown. The objectives of this study profile are to:

1. Document seasonal distribution and abundance of sea otters both within and adjacent to the Sale 92 Area.

2. Document seasonal habitat use patterns of sea otters both within and adjacent to the Sale 92 Area.

\section{Methods}

1. Conduct quarterly aerial surveys of sea otter distribution and abundance in Bristol Bay.

2. Monitor individual sea otter movements and survival using implanted radiotelemetry instruments.

\section{Cost and Level of Effort}

- FY 2009: \$670,000 (development of aerial survey design, initiation of quarterly surveys, deployment of radiotelemetry instruments, and initiation of telemetry monitoring)

- FY 2010: \$500,000 (quarterly surveys and telemetry monitoring)

- FY 2011: \$100,000 (data analysis and reporting)

- Total Cost: \$1.27 million

Included costs: development of aerial survey design: \$20,000; radiotelemetry implants: $\$ 150,000$; fixed wing aircraft charter for aerial surveys: $\$ 100,000$ per survey; fixed wing aircraft charter for monitoring radio-implanted otters: \$100,000/year.

Date Information Is Required: Annual summary reports due December each year. Final report due September 2011. 